Nevada

Environmental

Restoration

Project

Streamlined Approach for

Environmental Restoration (SAFER)

Plan for Corrective Action Unit 538:

Spill Sites

Nevada Test Site, Nevada

Controlled Copy No::

Revision No.: 0

April 2006

Approved for public release; further dissemination unlimited.

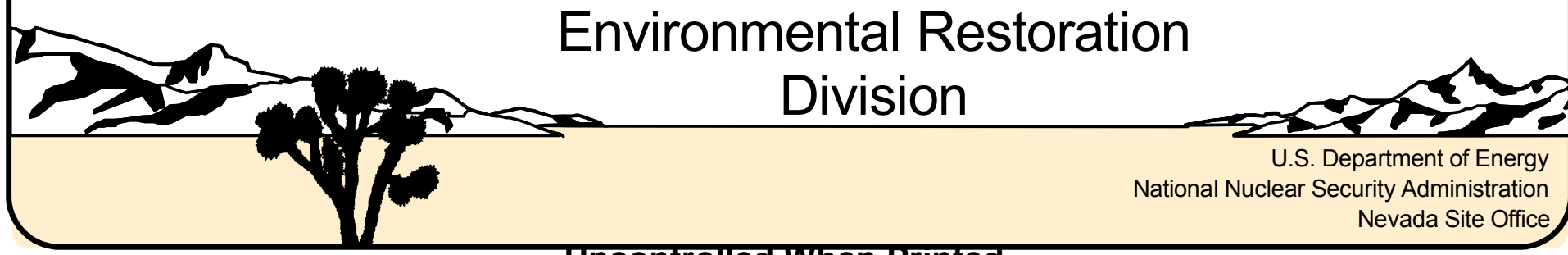


Available for public sale, in paper, from:

U.S. Department of Commerce

National Technical Information Service

5285 Port Royal Road

Springfield, VA 22161

Phone: 800.553 .6847

Fax: 703.605.6900

Email: orders@ntis.gov

Online ordering: http://www.ntis.gov/ordering.htm

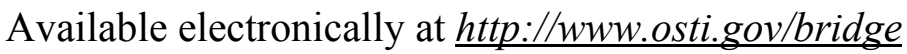

Available for a processing fee to U.S. Department of Energy and its contractors, in paper, from:

\section{U.S. Department of Energy}

Office of Scientific and Technical Information

P.O. Box 62

Oak Ridge, TN 37831-0062

Phone: 865.576 .8401

Fax: 865.576.5728

Email: reports@adonis.osti.gov

Reference herein to any specific commercial product, process, or service by trade name, trademark, manufacturer, or otherwise, does not necessarily constitute or imply its endorsement, recommendation, or favoring by the United States Government or any agency thereof or its contractors or subcontractors. 


\title{
STREAMLINED APPROACH FOR ENVIRONMENTAL RESTORATION (SAFER) PLAN FOR CORRECTIVE ACTION UNIT 538: SPILL SITES NEVADA TEST SITE, NEVADA
}

\author{
U.S. Department of Energy \\ National Nuclear Security Administration \\ Nevada Site Office \\ Las Vegas, Nevada
}

Controlled Copy No.:

Revision No.: 0

April 2006

Approved for public release; further dissemination unlimited. 
STREAMLINED APPROACH FOR ENVIRONMENTAL RESTORATION (SAFER)

PLAN FOR CORRECTIVE ACTION UNIT 538: SPILL SITES

NEVADA TEST SITE, NEVADA

Approved by: APPROVED SIGNATURE

Date: $4 / 11 / 06$

Sabine T. Curtis

Acting Federal Sub-Project Director

Environmental Restoration Project

Approved by: APPROVED SIGNATURE

Date: 4/11/06

Janet L. Appenzeller-Wing

Federal Project Director

Environmental Restoration Project 


\section{Table of Contents}

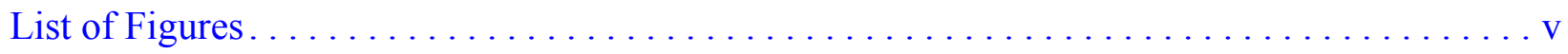

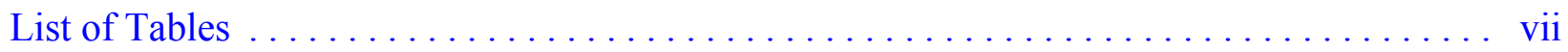

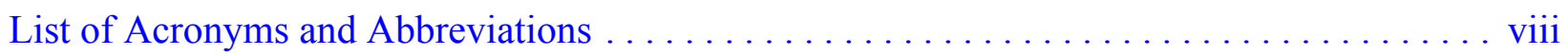

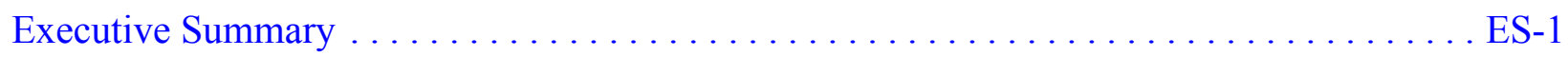

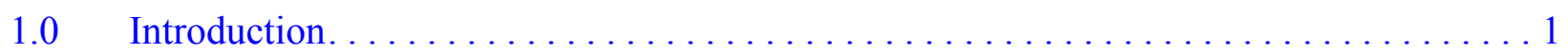

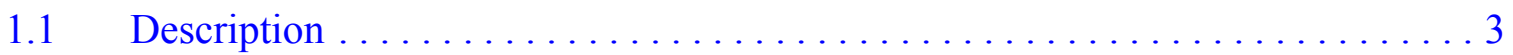

$1.2 \quad$ Summary of Corrective Actions and Closures ................... 3

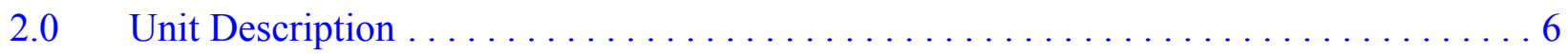

$2.1 \quad$ Corrective Action Site 02-21-01, Epoxy Tar Pit $\ldots \ldots \ldots \ldots \ldots \ldots \ldots$

2.1.1 History and Process Knowledge ................... 7

2.1.2 Available Characterization Information $\ldots \ldots \ldots \ldots \ldots \ldots \ldots . \ldots \ldots$

2.2 Corrective Action Site 03-25-04, Hydrocarbon Stain . . . . . . . . . . . 10

2.2.1 History and Process Knowledge $\ldots \ldots \ldots \ldots \ldots \ldots \ldots \ldots \ldots \ldots$

2.2.2 Available Characterization Information ................... 10

2.3 Corrective Action Site 06-09-01, Cement Washdown ............... 13

2.3.1 History and Process Knowledge .................... 13

2.3.2 Available Characterization Information ................ 16

2.4 Corrective Action Site 06-44-05, Diesel Spill From Tank \#38061 . . . . . . . . 17

2.4.1 History and Process Knowledge ................... 17

2.4.2 Available Characterization Information ............... 20

2.5 Corrective Action Site 06-44-06, Spill Site with Hydrocarbons . . . . . . . . . 20

2.5.1 History and Process Knowledge .................... 23

2.5.2 Available Characterization Information ................. 23

2.6 Corrective Action Site 12-29-06, Spill Site . . . . . . . . . . . . . . . . 24

2.6.1 History and Process Knowledge .................... 24

2.6.2 Available Characterization Information ................ 27

2.7 Corrective Action Site 23-25-01, Oil Stains . . . . . . . . . . . . . . . 27

2.7.1 History and Process Knowledge $\ldots \ldots \ldots \ldots \ldots \ldots \ldots \ldots \ldots \ldots$

2.7.2 Available Characterization Information ................ 31

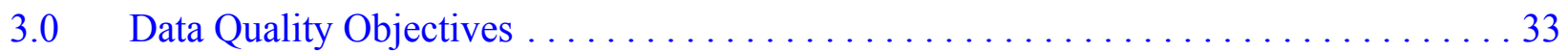

$3.1 \quad$ Summary of the DQO Analysis . . . . . . . . . . . . . . . . . . . . 33

3.2 Results of the DQO Analysis ................................ 34

3.2.1 Action Level Determination and Basis ................. 34

3.2.1.1 Chemical PALs .......................... 39

3.2.1.2 Total Petroleum Hydrocarbons PALs . . . . . . . . . . . . . . 39

3.2.1.3 Radionuclide PALs . . . . . . . . . . . . . . . . . 40 


\section{Table of Contents (Continued)}

3.2.2 Hypothesis Test ............................. 40

$3.2 .3 \quad$ Statistical Model . . . . . . . . . . . . . . . . . . . . . . . 40

3.2.4 Design Description/Option . . . . . . . . . . . . . . . . 41

3.2.5 Conceptual Site Model and Drawing..................... 41

$4.0 \quad$ Field Activities and Closure Objectives . . . . . . . . . . . . . . . . . . . . 44

$4.1 \quad$ Contaminants of Potential Concern $\ldots \ldots \ldots \ldots \ldots \ldots \ldots \ldots \ldots \ldots \ldots 4$

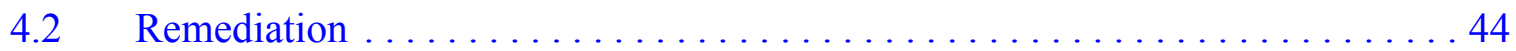

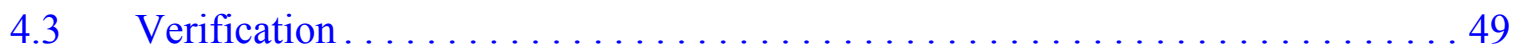

4.3.1 Corrective Action Site 02-21-01, Epoxy Tar Pit ............. 51

4.3.2 Corrective Action Site 03-25-04, Hydrocarbon Stain ............. 51

4.3.3 Corrective Action Site 06-09-01, Cement Washdown ........... 52

4.3.4 Corrective Action Site 06-44-05, Diesel Spill From Tank \#38061 . . . 52

4.3.5 Corrective Action Site 06-44-06, Spill Site with Hydrocarbons . . . . . . 53

4.3.6 Corrective Action Site 12-29-06, Spill Site . . . . . . . . . . . . 53

4.3.7 Corrective Action Site 23-25-01, Oil Stains . . . . . . . . . . . 54

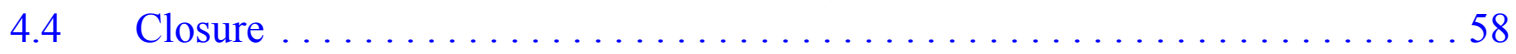

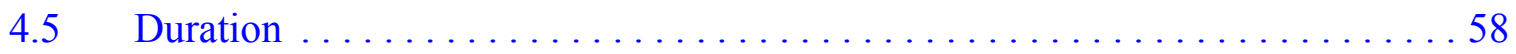

$5.0 \quad$ Reports and Records Availability . . . . . . . . . . . . . . . . . . . . . . . 59

$6.0 \quad$ Investigation/Remediation Waste Management .................... 60

$6.1 \quad$ Waste Minimization .................................... 60

$6.2 \quad$ Potential Waste Streams . . . . . . . . . . . . . . . . . . . . . 61

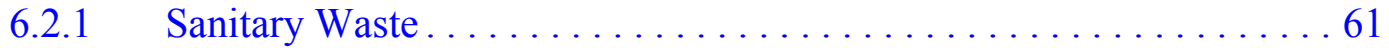

6.2.2 Low-Level Radioactive Waste. ....................... 61

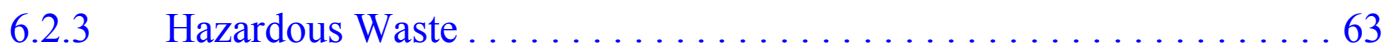

6.2 .4 Hydrocarbon Waste . . . . . . . . . . . . . . . . . . . . . 64

6.2 .5 Mixed Low-Level Waste. . . . . . . . . . . . . . . . . . . . . . 64

6.2.6 Polychlorinated Biphenyls......................... 64

6.3 Management of Specific Waste Streams . . . . . . . . . . . . . . . 65

6.3.1 Personal Protective Equipment . . . . . . . . . . . . . . . . . 65

6.3.2 Management of Soil............................. 65

6.3.3 Management of Debris..........................66 66

6.3.4 Management of Decontamination Rinsate. ................ 66

6.3.5 Field Screening Waste . . . . . . . . . . . . . . . . . . 67

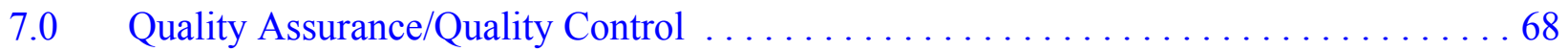

$7.1 \quad$ Sample Collection Activities . ..........................6 68

7.2 Applicable Laboratory/Analytical Data Quality Indicators . . . . . . . . . . 69

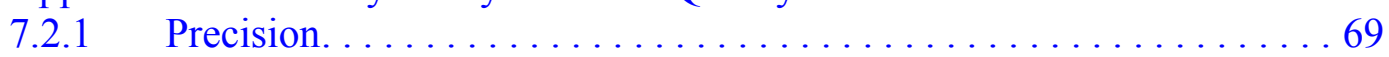

7.2.2 Accuracy/Bias .............................. 76 


\section{Table of Contents (Continued)}

7.2.3 Representativeness. ......................... 77

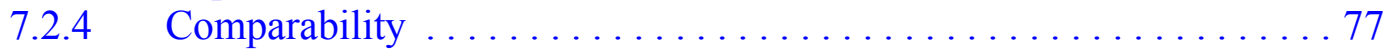

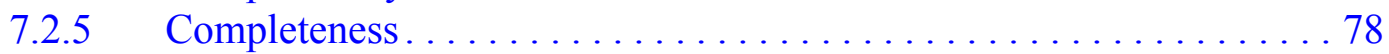

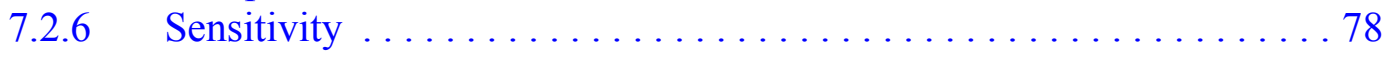

$8.0 \quad$ References.................................. 79

\section{Appendix A - Project Organization}

A.1.0 Project Organization $\ldots \ldots \ldots \ldots \ldots \ldots \ldots \ldots \ldots \ldots \ldots \ldots \ldots \ldots \ldots \ldots \ldots \ldots \ldots \ldots \ldots$

\section{Appendix B - Data Quality Objective Process}

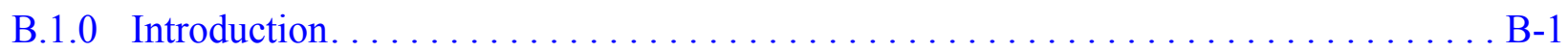

B.2.0 Step $1-$ State the Problem. . . . . . . . . . . . . . . . . . . .

B.2.1 Data Quality Objective Planning Team Members . . . . . . . . . . . . . . B-2

B.2.2 Conceptual Site Model . . . . . . . . . . . . . . . . . . . . . B-2

B.2.2.1 Contaminant Release . . . . . . . . . . . . . . . . . . . . . . B-4

B.2.2.2 Potential Contaminants . . . . . . . . . . . . . . . . . . . . B-9

B.2.2.3 Contaminant Characteristic . . . . . . . . . . . . . . B-11

B.2.2.4 Site Characteristics . . . . . . . . . . . . . . . . B-11

B.2.2.5 Migration Pathways and Transport Mechanisms. . . . . . . . . . . B-13

B.2.2.6 Exposure Scenarios . . . . . . . . . . . . . . . B-15

B.3.0 Step 2 - Identify the Decisions . . . . . . . . . . . . . . . . . B-18

B.3.1 Decision Statements . . . . . . . . . . . . . . . . . . B-18

B.3.2 Alternative Actions to the Decisions . . . . . . . . . . . . . B-18

B.3.2.1 Alternative Actions to Decision I . . . . . . . . . . . . . . B-20

B.3.2.2 Alternative Actions to Decision II . . . . . . . . . . . . . B-20

B.4.0 Step 3 - Identify the Inputs to the Decision . . . . . . . . . . . . . . . B-21

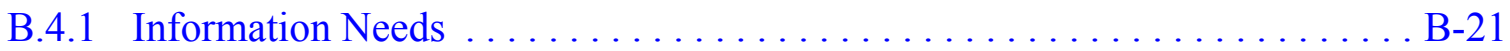

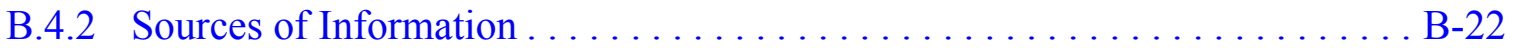

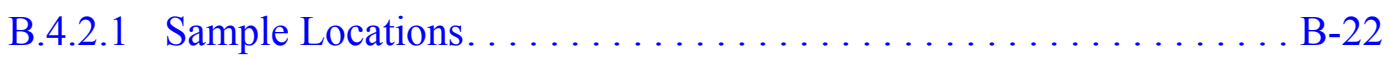

B.4.2.2 Analytical Methods . . . . . . . . . . . . . . B-24

B.5.0 Step 4 - Define the Boundaries of the Study $\ldots \ldots \ldots \ldots \ldots \ldots \ldots \ldots \ldots \ldots$. . . . . . . .

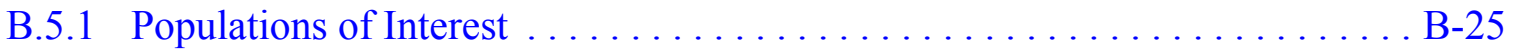

B.5.2 Spatial Boundaries . . . . . . . . . . . . . . . . . . . . . . . . .

B.5.3 Practical Constraints . . . . . . . . . . . . . . . . . . . . . . . . . .

B.5.4 Define the Scale of Decision Making . . . . . . . . . . . . B-26 


\section{Table of Contents (Continued)}

B.6.0 Step 5 - Develop a Decision Rule......................... B-28

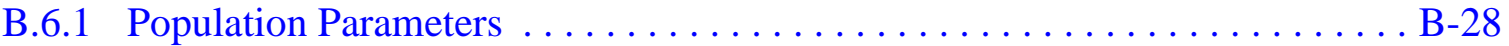

B.6.2 Decision Rules . . . . . . . . . . . . . . . . . . . . . . . . . . B-28

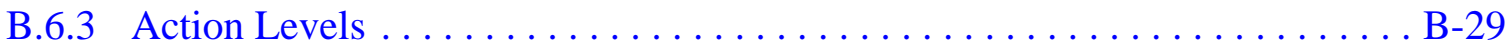

B.6.4 Measurement and Analysis Sensitivity . . . . . . . . . . . . . . . . . . B-30

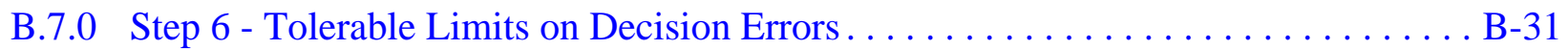

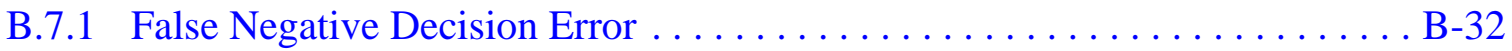

B.7.2 False Positive Decision Error . . . . . . . . . . . . . . . . . . B-34

B.8.0 Step 7 - Optimize the Approach for Obtaining Data $\ldots \ldots \ldots \ldots \ldots \ldots \ldots$ B-35

B.8.1 Corrective Action Site CAS 02-21-01, Epoxy Tar Pit ............. B-36

B.8.2 Corrective Action Site 03-25-04, Hydrocarbon Stain . . . . . . . . . . . B-37

B.8.3 Corrective Action Site 06-09-01, Cement Washdown .............. B-39

B.8.4 Corrective Action Site 06-44-05, Diesel Spill from Tank \#38061 . . . . . . . . . B-41

B.8.5 Corrective Action Site 06-44-06, Spill Site with Hydrocarbons . . . . . . . . . B-43

B.8.6 Corrective Action Site 12-29-06, Spill Site . . . . . . . . . . . . . . . . . B-45

B.8.7 Corrective Action Site 23-25-01, Oil Stains. . . . . . . . . . . . . . . B-47

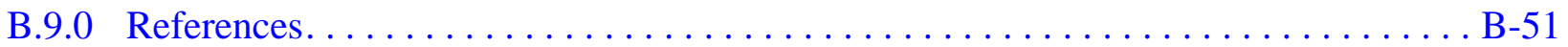

\section{Appendix C - Area 6 Land Use Restrictions and Bechtel Nevada} Use Restriction Information for UST 6-CP-9

C.1.0 Control Point South Land Use Restrictions $\ldots \ldots \ldots \ldots \ldots \ldots \ldots \ldots \ldots$ C-1

Appendix D - Nevada Division of Environmental Protection Comments 


\section{List of Figures}

Number

Title

Page

1-1 Nevada Test Site Map with CAU 538 CAS Locations . . . . . . . . . . . . 2

1-2 SAFER Closure Decision Process For CAU $538 \ldots \ldots \ldots \ldots \ldots \ldots \ldots$

2-1 CAS 02-21-01, Epoxy Tar Pit, Location Map. . . . . . . . . . . . . 8

2-2 CAS 02-21-01, Epoxy Tar Pit, Site Layout. . . . . . . . . . . . . . 9

2-3 CAS 03-25-04, Hydrocarbon Stain, Location Map. . . . . . . . . . . . . . 11

2-4 CAS 03-25-04, Hydrocarbon Stain, Site Layout. . . . . . . . . . . . . . . . 12

2-5 CAS 06-09-01, Cement Washdown, Location Map . . . . . . . . . . . . . . . 14

2-6 CAS 06-09-01, Cement Washdown, Site Layout . . . . . . . . . . . . 15

2-7 CAS 06-44-05, Diesel Spill From Tank \#38061, Location Map . . . . . . . . . 18

2-8 CAS 06-44-05, Diesel Spill From Tank \#38061, Site Layout . . . . . . . . . . . . 19

2-9 CAS 06-44-06, Spill Site with Hydrocarbons, Location Map. . . . . . . . . . . . . 21

2-10 CAS 06-44-06, Spill Site with Hydrocarbons, Site Layout. . . . . . . . . . . . . . 22

2-11 CAS 12-29-06, Spill Site, Location Map . . . . . . . . . . . . . . . . . 25

2-12 CAS 12-29-06, Spill Site, Site Layout . . . . . . . . . . . . . . . 26

2-13 CAS 23-25-01, Oil Stains, Location Map . . . . . . . . . . . . . . . . . . 29

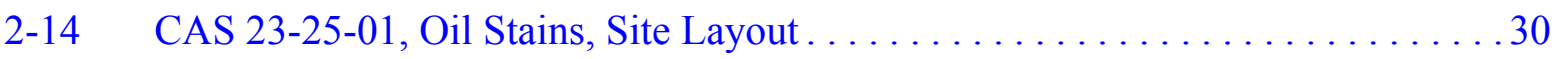

3-1 Process Used to Move Preliminary Action Levels to Final Action Levels . . . . . 37

3-2 Conceptual Site Model for CAU 538 Corrective Action Sites . . . . . . . . . . . 42

3-3 Conceptual Site Model Diagram for CAU 538 Corrective Action Sites. . . . . . . 43

B.2-1 Conceptual Site Model for CAU 538 Corrective Action Sites . . . . . . . . . . . B-5

B.2-2 Conceptual Site Model Diagram for CAU 538 Corrective Action Sites. . . . . . B-6

B.3-1 SAFER Closure Decision Process for CAU 538. . . . . . . . . . . . . . . B-19

B.8-1 Site Conditions at CAS $02-21-01 \ldots \ldots \ldots \ldots \ldots \ldots \ldots \ldots \ldots \ldots \ldots \ldots \ldots$

B.8-2 CAS 02-21-01, Epoxy Tar Pit, Planned Sample Locations. . . . . . . . . . . . . B-38

B.8-3 Site Conditions at CAS 03-25-04 . . . . . . . . . . . . . . . . . B-39 


\section{List of Figures (Continued)}

Number

Title

Page

B.8-4 CAS 03-25-04, Hydrocarbon Stain, Planned Sample Locations . . . . . . . . . B B-40

B.8-5 Site Conditions at CAS $06-09-01 \ldots \ldots \ldots \ldots \ldots \ldots \ldots \ldots \ldots \ldots \ldots \ldots \ldots \ldots$

B.8-6 CAS 06-09-01, Cement Washdown, Site Walkover ............... B-42

B.8-7 Site Conditions at CAS $06-44-05 \ldots \ldots \ldots \ldots \ldots \ldots \ldots \ldots \ldots \ldots \ldots \ldots$

B.8-8 CAS 06-44-05, Diesel Spill From Tank \#38061, Planned Sample Locations . . . . . . . . . . . . . . . . . . . . B-44

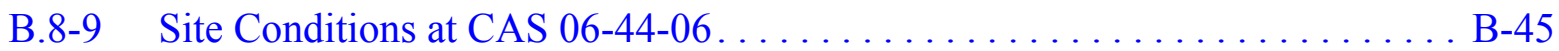

B.8-10 CAS 06-44-06, Spill Site with Hydrocarbons, Planned Sample Locations . . . . . . . . . . . . . . .

B.8-11 Site Conditions at CAS $12-29-06 \ldots \ldots \ldots \ldots \ldots \ldots \ldots \ldots \ldots \ldots \ldots \ldots \ldots \ldots \ldots$

B.8-12 CAS 12-29-06, Spill Site, Planned Sample Locations . . . . . . . . . . . . B B-48

B.8-13 Site Conditions at CAS $23-25-01 \ldots \ldots \ldots \ldots \ldots \ldots \ldots \ldots \ldots \ldots \ldots \ldots \ldots \ldots$

B.8-14 CAS 23-25-01, Oil Stains, Planned Sample Locations............... B-50

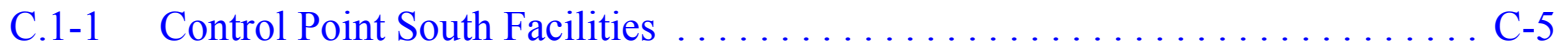




\section{List of Tables}

Number

Title

Page

ES.1-1 Summary of Conceptual Site Model Assumptions

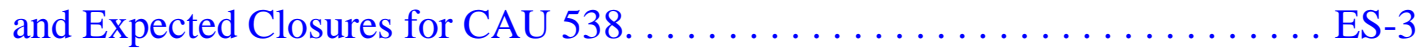

3-1 Contaminants of Potential Concern and Targeted Analytes for CAU 538 Corrective Action Sites . . . . . . . . . . . . . . . . 35

3-2 Analytes Reported by Analytical Methods ................... 36

4-1 Sampling Approach for CAU 538 Corrective Action Sites. . . . . . . . . . . 55

4-2 Tentative Duration of Activities for SAFER Activities $\ldots \ldots \ldots \ldots \ldots \ldots$

6-1 Waste Management Regulations and Requirements . . . . . . . . . . 62

7-1 Data Quality Indicator Performance Metrics. . . . . . . . . . . . . . 70

7-2 Analytical Requirements for Radionuclides for CAU $538 \ldots \ldots \ldots \ldots \ldots 71$

7-3 Analytical Requirements for Nonradiological Analytes for CAU 538 . . . . . . 73

B.2-1 Planning Meeting Participants for CAU 538 DQO December 15, 2005. . . . . . B-3

B.2-2 Conceptual Site Model Description of Elements

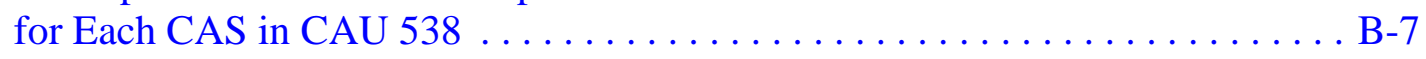

B.2-3 Contaminants of Potential Concern and Targeted Analytes for CAU 538 Corrective Action Sites . . . . . . . . . . . . . . . B-10

B.2-4 Exposure Scenarios for CAU 538 Corrective Action Sites. . . . . . . . . . . B-16

B.2-5 Future Land-Use Zones for CAU 538 Corrective Action Sites. . . . . . . . . . B-17

B.5-1 Spatial Boundaries of CAU 538 CASs $\ldots \ldots \ldots \ldots \ldots \ldots \ldots \ldots \ldots \ldots$

B.5-2 Practical Constraints for the CAU 538 Field Investigation. . . . . . . . . . B-27

C.1-1 Area 6 Land Use Restriction Site Location Nevada Division of Emergency Management. . . . . . . . . . . . . . . . . . C-1 


\section{List of Acronyms and Abbreviations}

AST

ASTM

a.k.a.

bgs

$\mathrm{BN}$

BJY

$\mathrm{C}$

CADAC Control and Data Acquisition Center

CAI

CAS

CAU

CFR

CLP

$\mathrm{COC}$

COPC

$\mathrm{CP}$

cps

CR

CRQL

CSM

DOE

DOE/NV

DOT

$\mathrm{dpm}$

DQI

DQO

Aboveground storage tank

Also known as

Below ground surface

Bechtel Nevada

Buster Jangle Wye

Carbon

Corrective Action Investigation

Corrective action site

Corrective action unit

Code of Federal Regulations

Contract Laboratory Program

Contaminant of concern

Contaminant of potential concern

Control Point

Counts per second

Closure Report

Contract-required quantitative limit

Conceptual site model

U.S. Department of Energy

U.S. Department of Transportation

Disintegrations per minute

Data quality indicator

Data quality objective
American Society for Testing and Materials

U.S. Department of Energy, Nevada Operations Office 


\section{List of Acronyms and Abbreviations (Continued)}

DRO Diesel-range organics

EPA U.S. Environmental Protection Agency

FAL Final action level

FFACO Federal Facility Agreement and Consent Order

FID Flame-ionization detector

FIMS Facilities Information Management System

FSL Field-screening level

FSR Field-screening result

$\mathrm{ft} \quad$ Foot

$\mathrm{ft}^{2} \quad$ Square foot

gal Gallon

$\mathrm{g} / \mathrm{L} \quad$ Gram per liter

GPS Global Positioning System

HASL Health and Safety Laboratory

IDW Investigation-derived waste

in. Inch

in./yr Inch per year

IRIS Integrated Risk Information System

LCS Laboratory control sample

LUR Land Use Restriction

MDC Minimum detectable concentration

$\mathrm{mg} / \mathrm{kg} \quad$ Milligram per kilogram

$\mathrm{mg} / \mathrm{L} \quad$ Milligrams per liter

mi Mile

mrem/yr Millirem per year

MS Matrix spike 


\section{List of Acronyms and Abbreviations (Continued)}

\begin{tabular}{|c|c|}
\hline MSD & Matrix spike duplicate \\
\hline $\mathrm{N} / \mathrm{A}$ & Not applicable \\
\hline NAC & Nevada Administrative Code \\
\hline NAD & North American Datum \\
\hline ND & Normalized difference \\
\hline NDEP & Nevada Division of Environmental Protection \\
\hline NDEM & Nevada Division of Emergency Management \\
\hline NNSA/NSO & $\begin{array}{l}\text { U.S. Department of Energy, National Nuclear Security Administration } \\
\text { Nevada Site Office }\end{array}$ \\
\hline NRS & Nevada Revised Statues \\
\hline NTS & Nevada Test Site \\
\hline NTSWAC & Nevada Test Site Waste Acceptance Criteria \\
\hline PACM & Presumed asbestos-containing material \\
\hline PAL & Preliminary action level \\
\hline PCB & Polychlorinated biphenyl \\
\hline $\mathrm{pCi} / \mathrm{g}$ & Picocuries per gram \\
\hline $\mathrm{pCi} / \mathrm{L}$ & Picocuries per liter \\
\hline PID & Photoionization detector \\
\hline POC & Performance Objective for the Certification of Nonradioactive Hazardous Waste \\
\hline PPE & Personal protective equipment \\
\hline ppm & Parts per million \\
\hline PRG & Preliminary remediation goal \\
\hline QA & Quality assurance \\
\hline QAPP & Quality Assurance Project Plan \\
\hline QC & Quality control \\
\hline RadCon & Radiation Control \\
\hline RBCA & Risk-based corrective action \\
\hline
\end{tabular}




\section{List of Acronyms and Abbreviations (Continued)}

\begin{tabular}{|c|c|}
\hline RBSL & Risk-based screening level \\
\hline RCRA & Resource Conservation and Recovery Act \\
\hline REECo & Reynolds Electrical \& Engineering Co., Inc. \\
\hline RMA & Radioactive materials area \\
\hline RPD & Relative percent difference \\
\hline SAFER & Streamlined Approach for Environmental Restoration \\
\hline SAIC & Science Applications International Corporation \\
\hline SD & Standard deviation \\
\hline SDG & Sample delivery group \\
\hline SDWS & Safe Drinking Water Standards \\
\hline SNJV & Stoller-Navarro Joint Venture \\
\hline SSTL & Site-specific target level \\
\hline SVOC & Semivolatile organic compound \\
\hline SW & Solid waste \\
\hline TBD & To be determined \\
\hline TCLP & Toxicity Characteristic Leaching Procedure \\
\hline $\mathrm{TPH}$ & Total petroleum hydrocarbons \\
\hline TSCA & Toxic Substances Control Act \\
\hline UGTA & Underground Test Area \\
\hline UST & Underground storage tank \\
\hline UTM & Universal Transverse Mercator \\
\hline VOC & Volatile organic compound \\
\hline $\mathrm{yd}^{3}$ & Cubic yard \\
\hline$\mu \mathrm{R} / \mathrm{h}$ & Microentgens per hour \\
\hline$\% \mathrm{R}$ & Percent recovery \\
\hline
\end{tabular}




\section{Executive Summary}

This Streamlined Approach for Environmental Restoration (SAFER) Plan addresses closure for Corrective Action Unit (CAU) 538, Spill Sites, identified in the Federal Facility Agreement and Consent Order (1996). Corrective Action Unit 538 consists of the following seven corrective action sites (CASs) located in Areas 2, 3, 6, 12, and 23 of the Nevada Test Site:

- 02-21-01, Epoxy Tar Pit

- 03-25-04, Hydrocarbon Stain

- 06-09-01, Cement Washdown

- 06-44-05, Diesel Spill from Tank \#38061

- 06-44-06, Spill Site with Hydrocarbons

- 12-29-06, Spill Site

- 23-25-01, Oil Stains

This plan provides the methodology for field activities needed to gather the necessary information on the nature and extent of potential contamination to evaluate and confirm closure of each CAS. There is sufficient information and process knowledge from historical documentation and investigations of similar sites regarding the expected nature and extent of potential contaminants to recommend closure of CAU 538 using the SAFER process.

The data quality objective process developed for this CAU identified no further actions as the expected closure alternative. However, if the analytical results do not support this recommendation, the following closure options will be evaluated: (1) characterization of the nature and extent of contamination leading to closure in place with use restrictions, or (2) clean closure by remediation and verification. The expected closure options were selected based on available information including contaminants of potential concern, future land use, and assumed risks. A decision flow process was developed to outline the collection of data necessary to achieve closure. There are two decisions that need to be answered for closure. Decision I is to conduct an investigation to determine whether any contaminants of concern (COCs) exist in the environmental media within the CASs in CAU 538. If COCs are found to be present, Decision II will include conducting an investigation necessary to identify the vertical and lateral extent of contamination, evaluating information to select an appropriate corrective action alternative to complete closure of the site, and generating information necessary to confirm that the chosen closure alternative objectives were met. 
The following text summarizes the types of activities that will support the closure of CAU 538:

- Perform site preparation activities (e.g., utilities clearances, radiological surveys).

- Perform housekeeping activities for debris at various CASs, as required.

- Collect environmental samples from designated target populations (i.e., soil) and submit for laboratory analysis.

- If no contaminants are detected above final action levels, then the closure alternative is no further action.

- If COCs are present, evaluate and select either clean closure or closure in place as the appropriate corrective action alternative.

- If clean closure is chosen, the material to be remediated will be removed and disposed of as waste, and verification samples will be collected from remaining soil.

- If closure in place is chosen, conduct additional sampling to define the nature and extent of contamination. The appropriate use restrictions will be implemented.

- Confirm the corrective action alternative is adequate to protect human health and the environment.

- All closure activities for CAU 538 will be documented in a Closure Report.

Historical information and process knowledge identified sources of potential contamination for the CASs within CAU 538. Table ES.1-1 provides a summary of the potential release mechanisms, conceptual site model assumptions, and expected closure alternatives.

Under the Federal Facility Agreement and Consent Order, the SAFER Plan will be submitted to the Nevada Division of Environmental Protection for approval. Field work will be conducted following approval of the plan. On completion of the field activities, a Closure Report will be prepared and submitted to the Nevada Division of Environmental Protection for review and approval. 
Table ES.1-1

Summary of Conceptual Site Model Assumptions and Expected Closures for CAU 538

(Page 1 of 2)

\begin{tabular}{|c|c|c|c|}
\hline $\begin{array}{c}\text { Corrective Action } \\
\text { Site }\end{array}$ & $\begin{array}{c}\text { Potential Release } \\
\text { Mechanisms of COCs }\end{array}$ & $\begin{array}{c}\text { Conceptual Site Model } \\
\text { Assumptions }^{a}\end{array}$ & $\begin{array}{l}\text { Expected } \\
\text { Closure }^{b}\end{array}$ \\
\hline $02-21-01$ & \multirow{4}{*}{$\begin{array}{l}\text { Any COPCs migrating from } \\
\text { observed stained soil are } \\
\text { expected to be contiguous } \\
\text { to the release points and } \\
\text { concentrations to decrease } \\
\text { with distance and depth } \\
\text { from the source. }\end{array}$} & $\begin{array}{l}\text { Limited lateral migration in the surface } \\
\text { soil and minimal vertical migration in } \\
\text { the shallow subsurface. } \\
\text { Runoff from precipitation may have } \\
\text { moved COPC laterally. } \\
\text { Liquid released to the surface from } \\
\text { previous activities (i.e., stemming } \\
\text { operations) over time may have } \\
\text { provided a hydraulic driver for vertical } \\
\text { migration of COPCs. }\end{array}$ & No Further Action \\
\hline 06-09-01 & & $\begin{array}{l}\text { Limited lateral migration in the surface } \\
\text { soil and minimal vertical migration in } \\
\text { the shallow subsurface. } \\
\text { Runoff from precipitation and } \\
\text { reworking the surface and shallow } \\
\text { surface soil may have moved COPCs } \\
\text { laterally. }\end{array}$ & No Further Action \\
\hline $03-25-04$ & & $\begin{array}{l}\text { Limited lateral migration in the surface } \\
\text { soil and minimal vertical migration in } \\
\text { the shallow subsurface. } \\
\text { Runoff from precipitation may have } \\
\text { moved COPC laterally. } \\
\text { Liquid released to the surface from the } \\
\text { former air compressor over time may } \\
\text { have provided a hydraulic driver for } \\
\text { vertical migration of COPCs. }\end{array}$ & No Further Action \\
\hline 06-44-05 & & $\begin{array}{l}\text { Limited lateral migration in the surface } \\
\text { soil bedrock anticipated beneath } \\
\text { surface soil. } \\
\text { Runoff from precipitation and the } \\
\text { reworking the surface and shallow } \\
\text { surface soil may have moved COPCs } \\
\text { laterally. }\end{array}$ & No Further Action \\
\hline
\end{tabular}


Table ES.1-1

Summary of Conceptual Site Model Assumptions and Expected Closures for CAU 538

(Page 2 of 2)

\begin{tabular}{|c|c|c|c|}
\hline $\begin{array}{c}\text { Corrective Action } \\
\text { Site }\end{array}$ & $\begin{array}{c}\text { Potential Release } \\
\text { Mechanisms of COCs }\end{array}$ & $\begin{array}{c}\text { Conceptual Site Model } \\
\text { Assumptions }^{a}\end{array}$ & $\begin{array}{l}\text { Expected } \\
\text { Closure }^{b}\end{array}$ \\
\hline $06-44-06$ & \multirow{3}{*}{$\begin{array}{l}\text { Any COPCs migrating from } \\
\text { observed stained soil are } \\
\text { expected to be contiguous } \\
\text { to the release points and } \\
\text { concentrations to decrease } \\
\text { with distance and depth } \\
\text { from the source. }\end{array}$} & $\begin{array}{l}\text { Limited lateral migration in the surface } \\
\text { soil and shallow subsurface in the } \\
\text { potentially contaminated soil located } \\
\text { north of the former UST 6-CP-9. } \\
\text { Runoff from precipitation may have } \\
\text { moved COPCs laterally. } \\
\text { Limited vertical migration in the } \\
\text { subsurface soil below } 12 \mathrm{ft} \text { bgs. } \\
\text { However, liquid released to the } \\
\text { subsurface from the former UST } \\
6-\text { CP-9 over time may also have } \\
\text { provided a hydraulic driver for vertical } \\
\text { migration of COPCs. }\end{array}$ & No Further Action \\
\hline $12-29-06$ & & $\begin{array}{l}\text { Limited lateral migration in the surface } \\
\text { soil and minimal vertical migration in } \\
\text { the shallow subsurface. } \\
\text { Runoff from precipitation and the } \\
\text { reworking of the surface and shallow } \\
\text { surface soil may have moved COPCs } \\
\text { laterally. }\end{array}$ & No Further Action \\
\hline $23-25-01$ & & $\begin{array}{l}\text { Limited lateral migration in the surface } \\
\text { soil and shallow subsurface, and } \\
\text { minimal vertical migration in the } \\
\text { subsurface soil. } \\
\text { Runoff from precipitation and the } \\
\text { reworking of the surface and shallow } \\
\text { surface soil may have moved COPCs } \\
\text { laterally. }\end{array}$ & No Further Action \\
\hline
\end{tabular}

aSampling intervals for this investigation are designated as the following: Surface is 0 to $0.5 \mathrm{ft}$ bgs, shallow subsurface is 0.5 to $5 \mathrm{ft} \mathrm{bgs}$, and subsurface is greater than $5 \mathrm{ft}$ bgs.

${ }^{b}$ Expected closure alternative for all CASs is no further action; however, if data are insufficient, clean closure and closure in place will be evaluated.

bgs $=$ Below ground surface

$\mathrm{COC}=$ Contaminant of concern

COPC $=$ Contaminant of potential concern

$\mathrm{ft}=$ Foot

UST = Underground storage tank 


\subsection{Introduction}

This Streamlined Approach for Environmental Restoration (SAFER) Plan addresses the actions necessary for the closure of Corrective Action Unit (CAU) 538: Spill Sites, Nevada Test Site, Nevada. It has been developed in accordance with the Federal Facility Agreement and Consent Order (FFACO) (1996) that was agreed to by the State of Nevada, the U.S. Department of Energy (DOE), and the U.S. Department of Defense.

A SAFER may be performed when the following criteria are met:

- Conceptual corrective actions are clearly identified (although some degree of investigation may be necessary to select a specific corrective action before completion of the Corrective Action Investigation [CAI]).

- Uncertainty of the nature, extent, and corrective action must be limited to an acceptable level of risk.

- The SAFER Plan includes decision points and criteria for making data quality objective (DQO) decisions.

The purpose of the investigation will be to document and verify the adequacy of existing information; to affirm the decision for either clean closure, closure in place, or no further action; and to provide sufficient data to implement the corrective action. The actual corrective action selected will be based on characterization activities implemented under this SAFER Plan. This SAFER Plan identifies decision points developed in cooperation with the Nevada Division of Environmental Protection (NDEP) and where DOE will reach consensus with NDEP before beginning the next phase of work.

Corrective Action Unit 538 is located in Areas 2, 3, 6, 12, and 23 of the Nevada Test Site (NTS), which is approximately 65 miles (mi) northwest of Las Vegas, Nevada (Figure 1-1). Corrective Action Unit 538 is comprised of the seven corrective action sites (CASs) shown on Figure 1-1 and listed below:

- 02-21-01, Epoxy Tar Pit

- 03-25-04, Hydrocarbon Stain

- 06-09-01, Cement Washdown

- 06-44-05, Diesel Spill from Tank \#38061

- 06-44-06, Spill Site with Hydrocarbons 


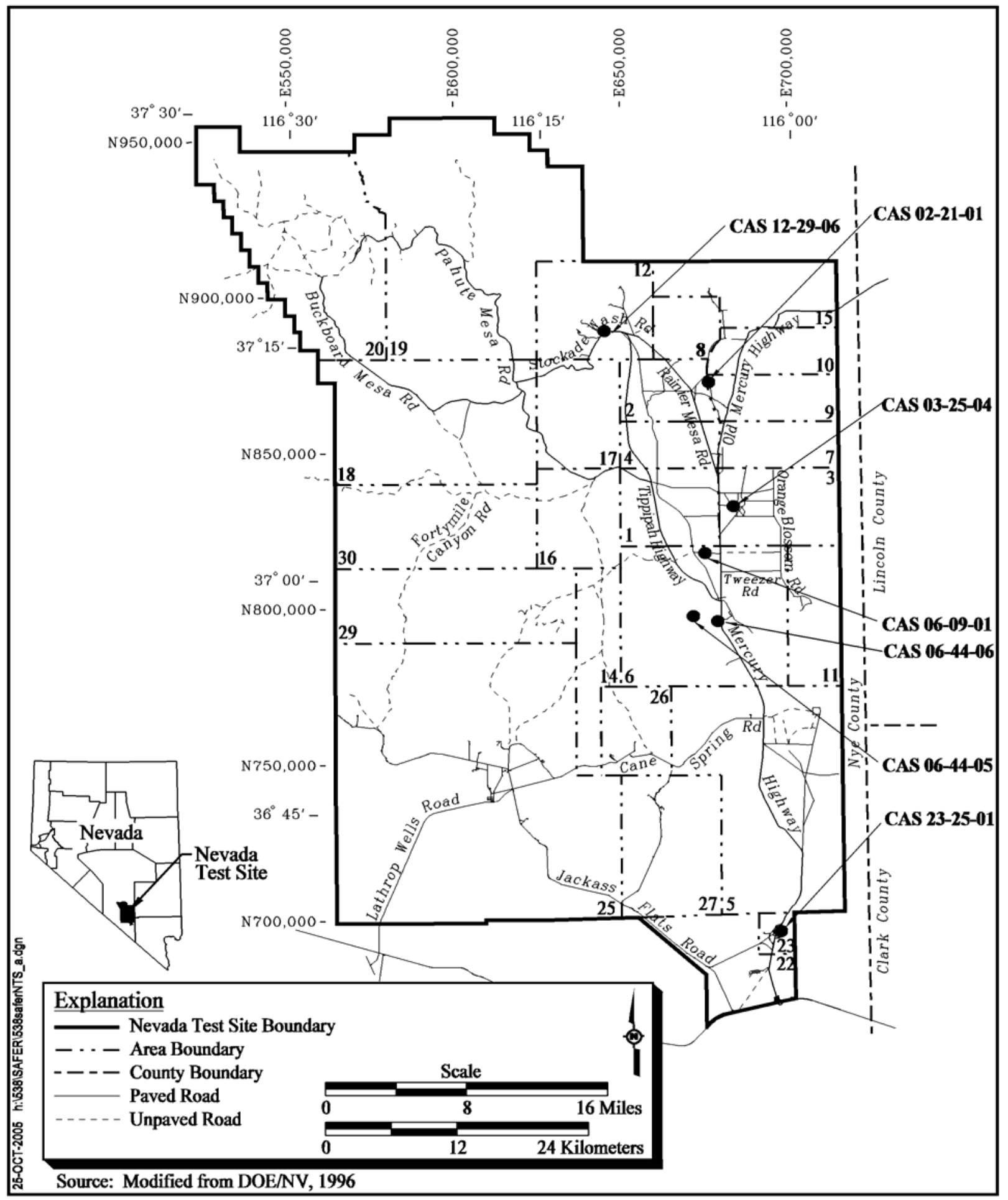

Figure 1-1

Nevada Test Site Map with CAU 538 CAS Locations 
- 12-29-06, Spill Site

- 23-25-01, Oil Stains

There is sufficient information and process knowledge from historical documentation and investigations of similar sites (i.e., the expected nature and extent of contaminants of potential concern [COPCs]) to recommend closure of CAU 538 using the SAFER process (FFACO, 1996).

\subsection{Description}

Corrective action units that may be closed using the SAFER process have conceptual corrective actions that are identified before the investigation phase. Consequently, corrective action alternatives can be identified before completing a corrective action investigation, given anticipated investigation results.

The SAFER process combines elements of the DQO process and the observational approach to plan and conduct closure activities. The DQOs are used to identify the problem and define the type and quality of data needed to complete closure of each CAS. The purpose of the investigation phase is to verify the adequacy of existing information used to determine the chosen corrective action and to confirm that closure objectives were met.

Use of the SAFER process allows for technical decisions to be made based on incomplete but sufficient information, and the experience of the decision maker. Based on a detailed review of historical documentation, there is sufficient process knowledge to close CAU 538 using the SAFER process. Any uncertainties addressed by documented assumptions will be verified by sampling and analysis, data evaluation, and on-site observations, as necessary. Closure activities may proceed simultaneously with site characterization as sufficient data are gathered to confirm or disprove the assumptions made during selection of the corrective action. If, at any time during the closure process, new information is discovered that indicates that closure activities should be revised, closure activities will be re-evaluated as appropriate.

\subsection{Summary of Corrective Actions and Closures}

The decision process for closure of CAU 538 is summarized in Figure 1-2. This process starts with the initial investigation in which the appropriate target populations within each CAS (defined in the 


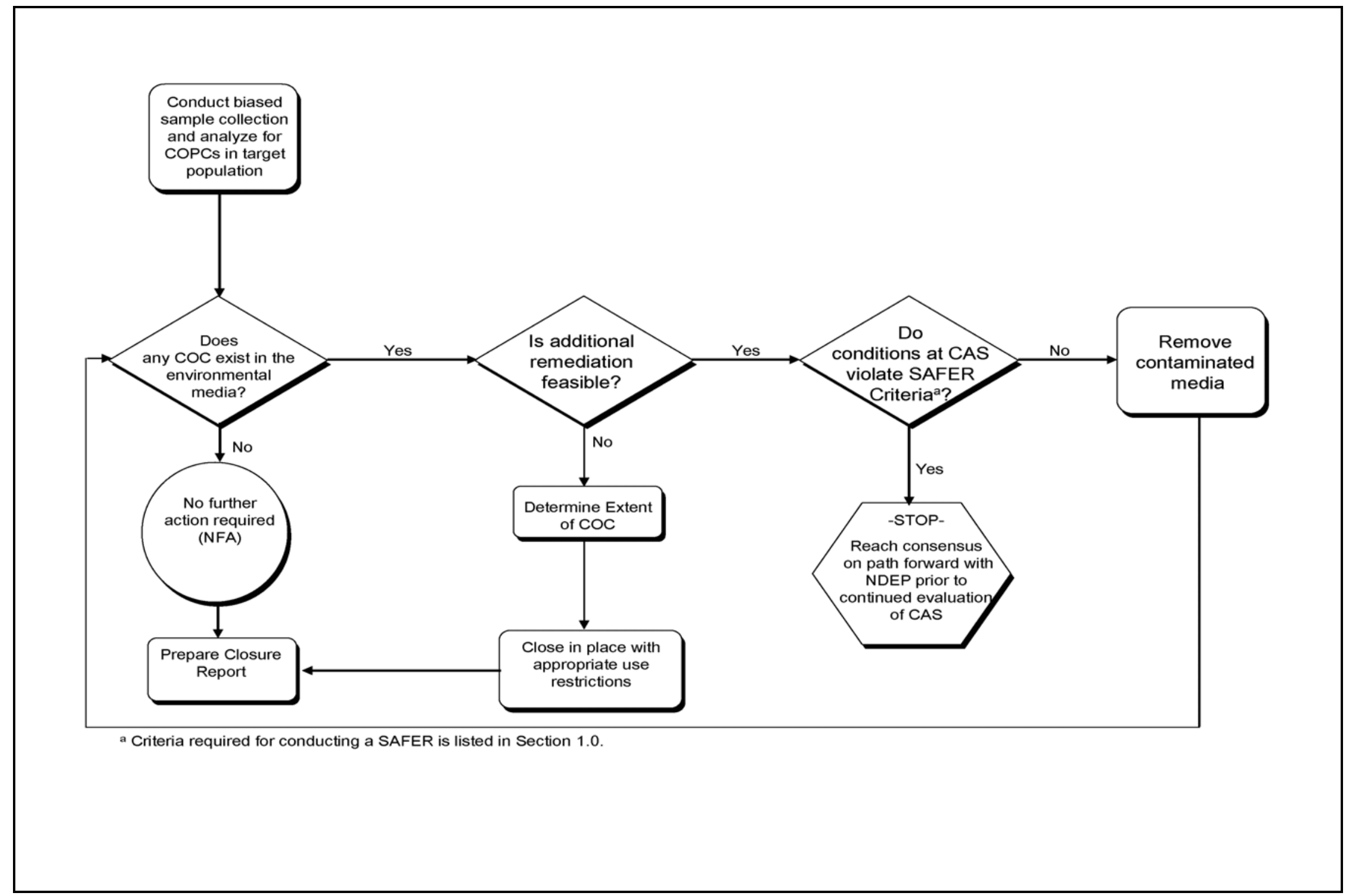

Figure 1-2

SAFER Closure Decision Process For CAU 538

\section{Uncontrolled When Printed}


DQO process, Appendix B) are sampled. If contaminants are detected at concentrations that are above the final action level (FAL), and remediation is feasible, then the nature and extent of contamination will be delineated. The process continues with additional sampling; however, the contingencies (i.e., clean closure or closure in place) are built into the process in the event new information is identified which indicates that the selected, preferred closure option (e.g., no further action) should be revised. The process ends with closure of the site based on laboratory analytical results of the environmental samples and the preparation of a Closure Report (CR). Corrective action alternatives of closure in place and clean closure will be evaluated for each CAS with contaminants above FALs.

Decision points that require a consensus be reached between the DOE, National Nuclear Security Administration Nevada Site Office (NNSA/NSO) and NDEP before continuing are indicated in Figure 1-2.

In addition to the previously discussed hold/decision points, work may be temporarily suspended if situations are identified that violate the following basic conditions of the SAFER process:

- Conditions outside the scope of work are encountered.

- Radiological screening yields results that require an upgrade in personal protective equipment (PPE) and procedures to continue survey work in specific areas.

- Elevated levels of additional contaminants of concern (COCs) are found that were not originally suspected to be present at the sites.

- Unexpected conditions including unexpected waste and/or contamination are encountered.

- Out-of-scope work activities are required due to the detection of other COCs that would require re-evaluating a disposal pathway, such as with hazardous or low-level waste streams.

- Unsafe conditions or work practices posing a threat to personnel, equipment, or the environment, not originally documented in the safety basis documents, are encountered. 


\subsection{Unit Description}

The CASs within CAU 538 are located within Areas 2, 3, 6, 12, and 23 of the NTS (see Figure 1-1). The operational history, process knowledge, and existing information for each CAS are summarized in this section. Process knowledge for the CASs in CAU 538 has been obtained through historical document reviews, engineering drawing and map reviews, and interviews with past and present NTS employees. Some uncertainty remains regarding general knowledge of past operations for this CAU. Site-specific historical documentation pertaining to operations at each CAS is also limited. Based on the process knowledge and information about the CASs, assumptions were made to formulate a conceptual site model (CSM) that describes the most probable scenario for the current conditions at each CAS. Section 3.2.5 provides additional information on the CSM developed for the CASs in CAU 538.

\subsection{Corrective Action Site 02-21-01, Epoxy Tar Pit}

Corrective Action Site 02-21-01 is located east of the U-2ao Crater on the border of Areas 2 and 9. This CAS consists of a release to the surface soil of an unknown substance that is dry, hard, and brown-to-black in color located in a pit measuring 83 by 42 feet ( $\mathrm{ft}$ ) at its widest points and approximately $4 \mathrm{ft}$ deep. This smaller pit is located in a larger pit or depression containing mud-like fill material. Based on aerial photographs, the larger pit measures 300 by $120 \mathrm{ft}$ at its widest points. The current boundaries of the smaller and larger pit were determined from observations made during site visits in 2005 and with aerial photographs. It was agreed to during the DQO that the scope of the CAS will include both the unknown substance in the smaller pit and the mud-like fill material in the larger pit. Historical aerial photographs show a fluid-like material in the depressions (i.e., pits, drainage patterns) that may have been associated with nearby drilling activities (i.e., stemming operations).

Based on analytical results of a sample from this material discussed in Section 2.1.2, it was determined that this material is not a tar. This substance will, therefore, be referred to as "unknown substance" in this document. The mud-like fill material may be drilling mud from drilling activities associated with nearby emplacement holes. 
Figure 2-1 shows the CAS location with respect to surrounding roads, building, and other physical features. Figure 2-2 shows the CAS boundaries and physical layout.

This CAS was first identified in the 1991 Reynolds Electrical \& Engineering Co., Inc. (REECo) document entitled, Nevada Test Site Inventory of Inactive and Abandoned Facilities and Waste Sites Areas 1-4, and was described as an abandoned epoxy tar pit dump (REECo, 1991a). Although historical documents and previous field forms state that this site is located east of the U-2av and/or the U-2au Craters, it has been determined that the site actually is located east of the U-2ao Crater.

\subsubsection{History and Process Knowledge}

Although the history of the site is uncertain, there is the potential that the unknown substance was related to previous testing activities (i.e., stemming operations) nearby the site. According to aerial photographs, the unknown substance appeared at some point between June 28, 1971, and September 23, 1989. The fill material in the pits may be drilling mud.

\subsubsection{Available Characterization Information}

Analytical Results - Sample ERS00169, as shown in Figure B.8-2, was collected August 27, 1997, at the edge of the unknown substance and consisted of soil and the unknown substance. The sample was analyzed for total volatile organic compounds (VOCs), total semivolatile organic compounds (SVOCs), total petroleum hydrocarbons (TPH)-diesel-range organics (DRO), and Resource Conservation and Recovery Act (RCRA) metals. The analyses detected concentrations of benzoic acid; the RCRA metals arsenic, barium, chromium, and lead; and bis(2-ethylhexyl)phthalate (an SVOC). All detected concentrations were below their respective preliminary action levels (PALs) (Bordelois, 1998). The concentration of radionuclides for gross alpha (21.0 picocuries per gram [pCi/g]), gross beta (30.5 pCi/g), and lead-212 (1.92 pCi/g) were also below PALs (Bordelois, 1998).

Radiological Survey Results - A radiological survey was conducted at CAS 02-21-01 on September 16, 1998. The activity detected during the survey were 26.5 disintegrations per minute (dpm) for alpha and 1,140 dpm for beta, which exceeded the background levels of $5.3 \mathrm{dpm}$ for alpha and $645 \mathrm{dpm}$ for beta (Bordelois, 1998). 


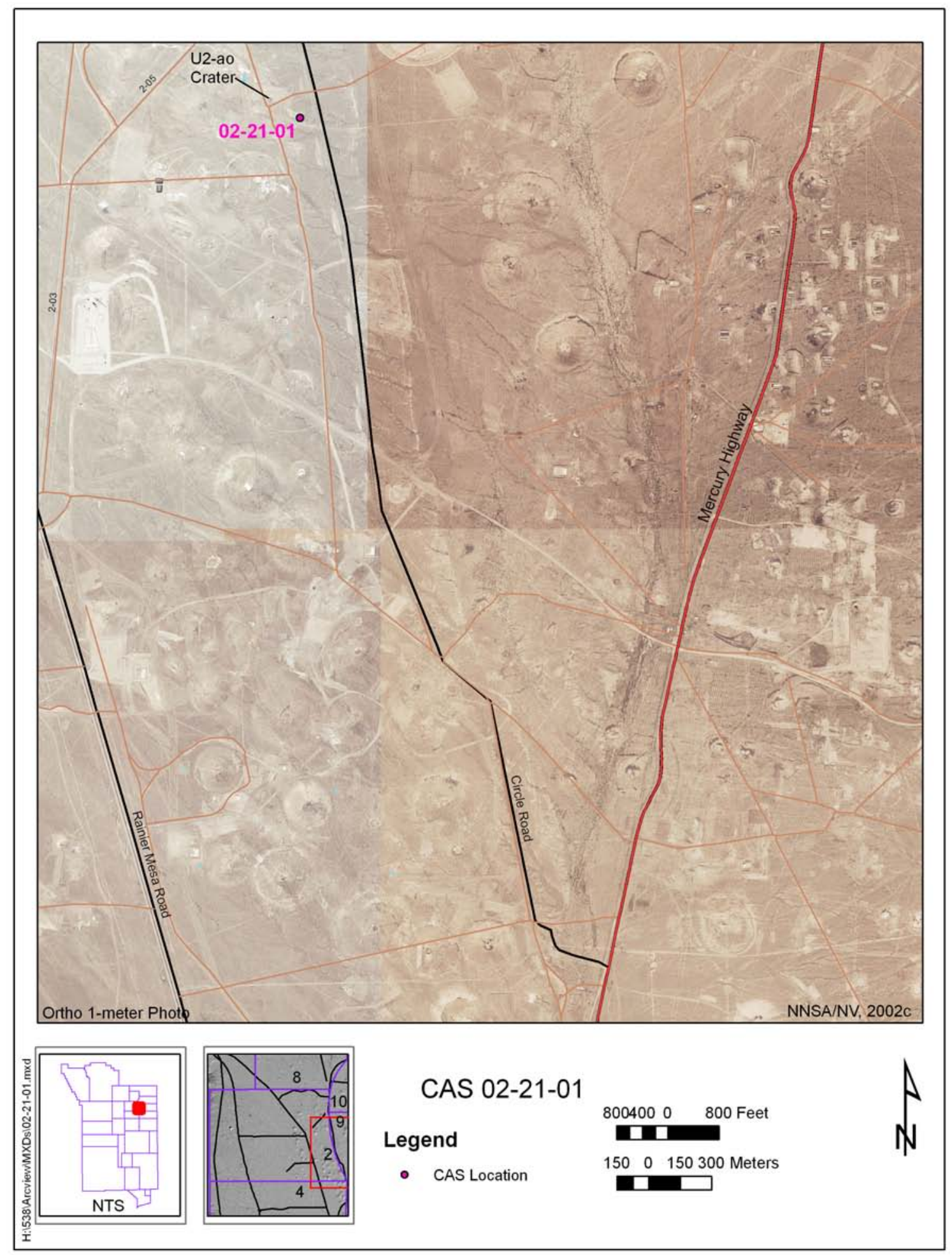

Figure 2-1

CAS 02-21-01, Epoxy Tar Pit, Location Map 


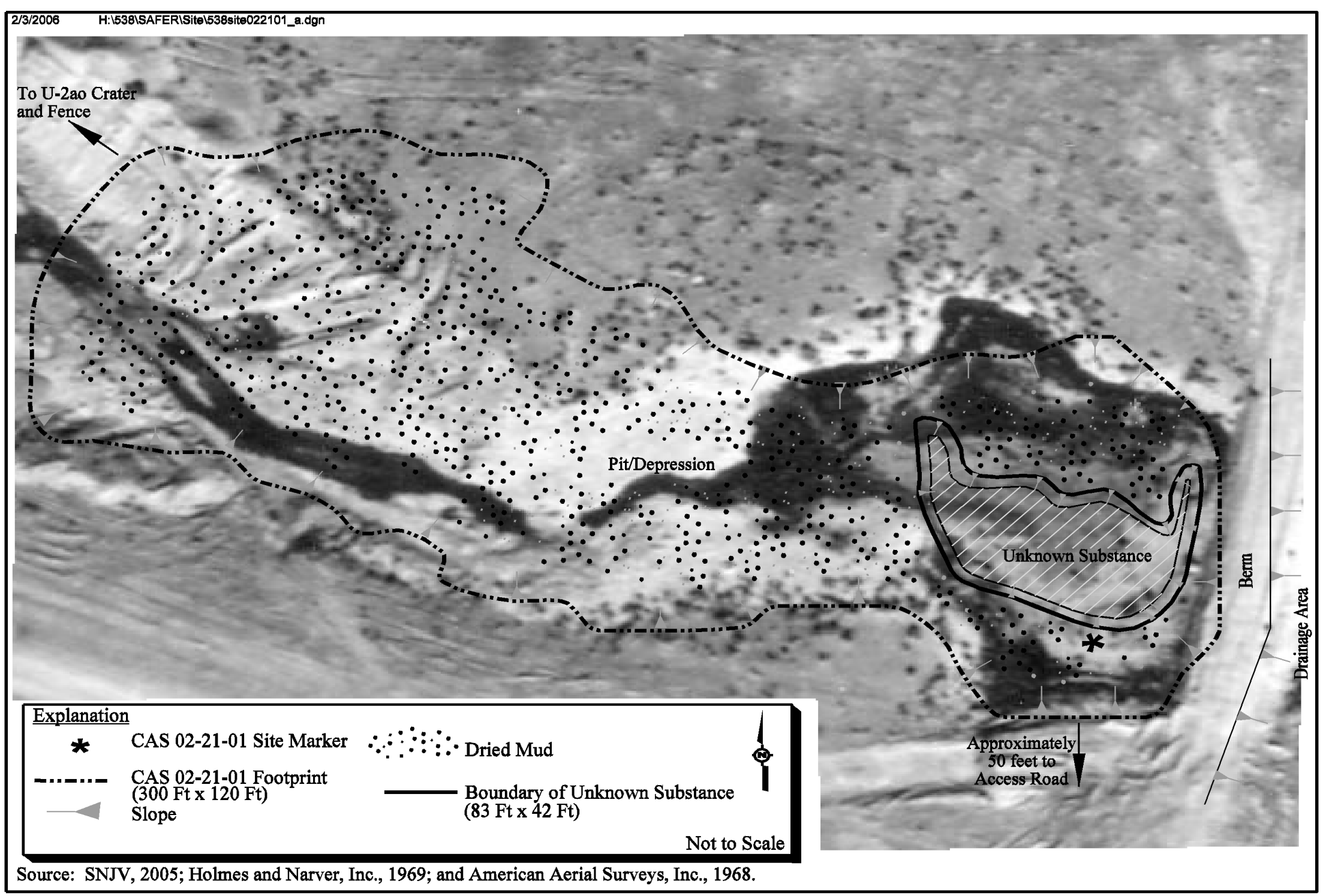

Figure 2-2

CAS 02-21-01, Epoxy Tar Pit, Site Layout 


\subsection{Corrective Action Site 03-25-04, Hydrocarbon Stain}

Corrective Action Site 03-25-04 is located on the south side of the former Sheet Metal Shop (Building 3C-18) and east side of the former Iron Workers' Shop in the Area 3 Camp. This CAS consists of a release onto the gravel surface where an air compressor was once located. The site was first identified in the 1996 letter from S.R. Weil (Bechtel Nevada [BN]) to J.A. Blodgett (U.S. Department of Energy, Nevada Operations Office [DOE/NV]) entitled, "Prospective Sites for Addition to Appendix 2 of the Federal Facilities Agreement and Consent Order (FFACO)" (Weil, 1996). The site was identified as a hydrocarbon stain in the compressor shack on the west side of the Area 3 Ironworkers Yard. The orange-brown stained soil is on the gravel pad of a former air compressor and measures approximately 14.75 by $14 \mathrm{ft}$. No vegetation is present in the area of the stained soil; however, heavy vegetation surrounds the stained soil area. Concrete foundations of former buildings are present adjacent to the site.

Figure 2-3 is an aerial photograph showing the CAS location with respect to the surrounding roads, buildings, and other physical features. Figure 2-4 shows the CAS boundaries, location of the stain, and adjacent structures.

\subsubsection{History and Process Knowledge}

Details of the operational history of the air compressor are unknown. According to an interview, the air compressor supplied Building 3C-18, the Sheet Metal Shop, with compressed air for pneumatic tools. Aerial photography and engineering drawings suggest that the air compressor was used between 1969 and 1994; however, it is unknown when the spill occurred. Historical documentation states that hydrocarbon stains were visible on the concrete pads; however, there is only one observable staining remaining in the area of the air compressor gravel pad (SNJV, 2005).

\subsubsection{Available Characterization Information}

Radiological Survey Results - No site-specific radiological surveys have been conducted at CAS 03-25-04; however, an aerial radiological survey was conducted in 1994 within 2,096 ft (survey location T3B) of CAS 03-25-04. The survey location T3B was the site of the Fizeau test conducted in 1957. The isotopes identified at T3B during the radiological survey were cobalt-60, zinc-65, and 


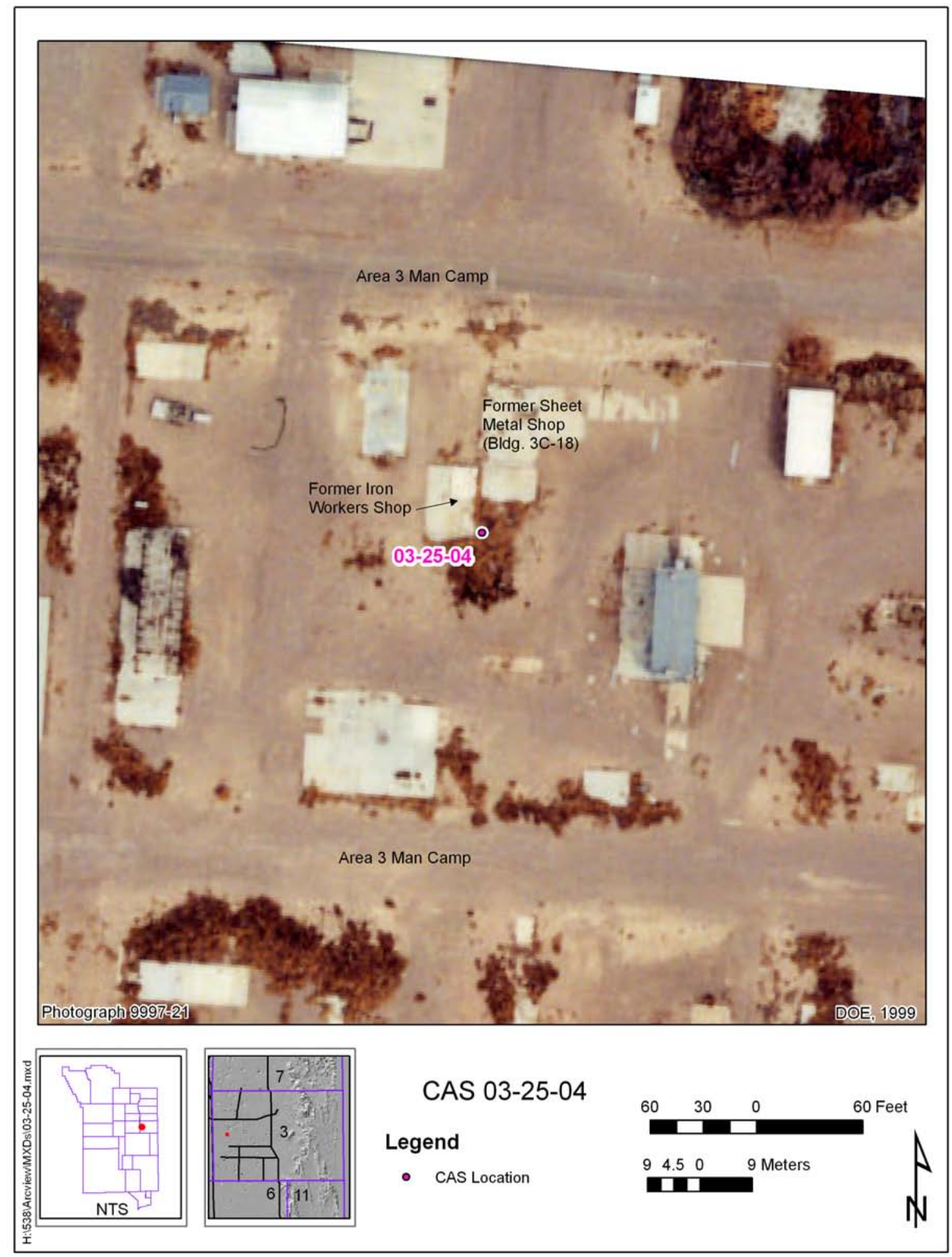

Figure 2-3

CAS 03-25-04, Hydrocarbon Stain, Location Map 


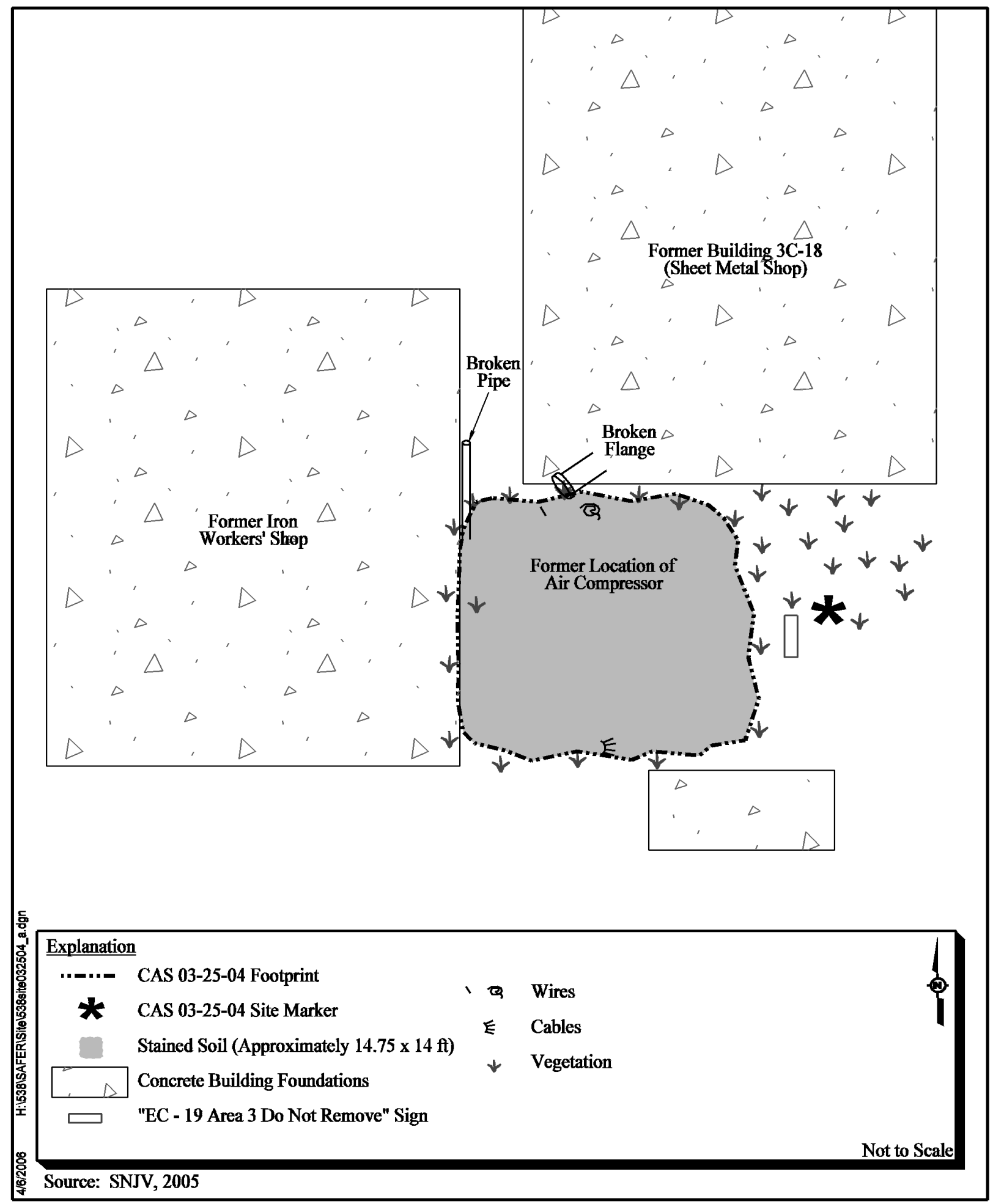

Figure 2-4

CAS 03-25-04, Hydrocarbon Stain, Site Layout 
cesium-134 and -137, with an exposure-rate range of 200 microentgens per hour $(\mu \mathrm{R} / \mathrm{hr})$ (BN, 1999a).

\subsection{Corrective Action Site 06-09-01, Cement Washdown}

Corrective Action Site 06-09-01 is a former cement washdown area located west of the Well 3 Yard in Area 6. This CAS consists of releases of cement to the surface resulting from washing cement trucks. The site was first identified in the 1991 REECo document entitled, Nevada Test Site Inventory of Inactive and Abandoned Facilities and Waste Sites Areas 5-10, as an approximately 2-acre cement washdown area (REECo, 1991b). The heaviest accumulation of cement appeared to be in the western side of the site, west of the cement mud pit (CAS 06-17-03 [CAU 392]). The cement accumulation thins out laterally east, west, north, and south. During a 2005 site visit, the visible extent of the cement at CAS 06-09-01 was measured to be approximately 9.2 acres (401,262.85 square feet [ $\left.\left.\mathrm{ft}^{2}\right]\right)$, which is larger than previously reported.

The current CAS boundary was defined during the 2005 DQO site visit. No environmental concerns have been identified at this CAS. However, a site walkover will be conducted to confirm that cement is the only material that has been release at this site.

Figure 2-5 shows the CAS location with respect to surrounding roads, buildings, and other physical features. Figure 2-6 shows the current CAS layout including the location of CAS 06-17-03 previously closed under CAU 392.

\subsubsection{History and Process Knowledge}

Halliburton initiated operations in the Area 6 Well 3 Yard around 1963. B.J. Titan took over these operations around 1983 and continued until the early 1990s. The purpose of the operations was to mix cement, which was trucked to various construction sites. These trucks were washed to remove excess cement and solids. As a result, an area west of Well 3 Yard was utilized for the disposal of cement wash-out wastes. Initially, the cement washdown area consisted of a cement mud pit (CAS 06-17-03 [CAU 392]) as shown in a 1968 aerial photograph (H\&N, 1968); however, it evolved into a cement pile over time. After 1980, pneumatic tanker trucks emptied dry, unmixed cement onto the cement pile. The powdered cement was spread around the vegetated area surrounding the cement 


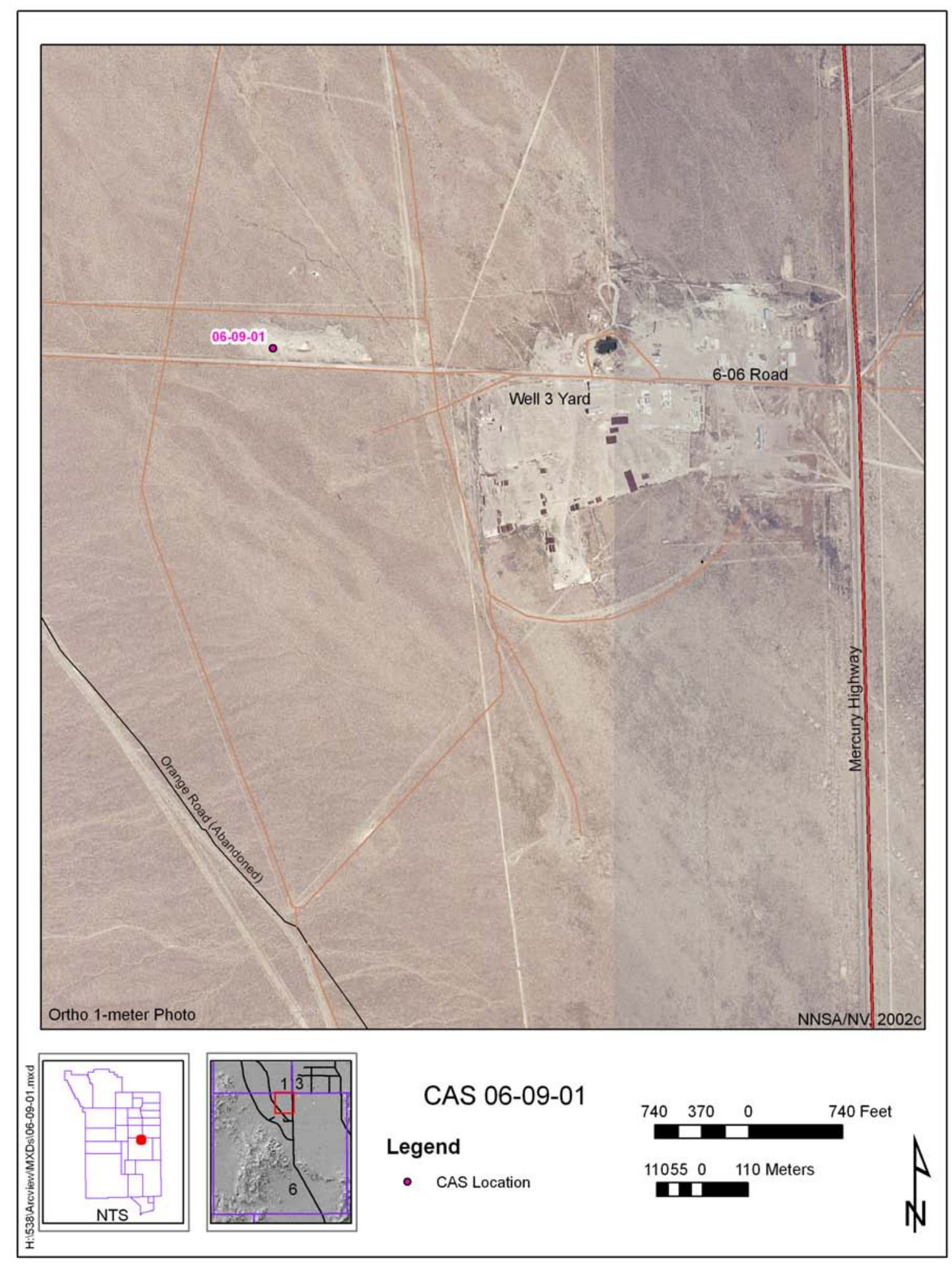

Figure 2-5

CAS 06-09-01, Cement Washdown, Location Map 


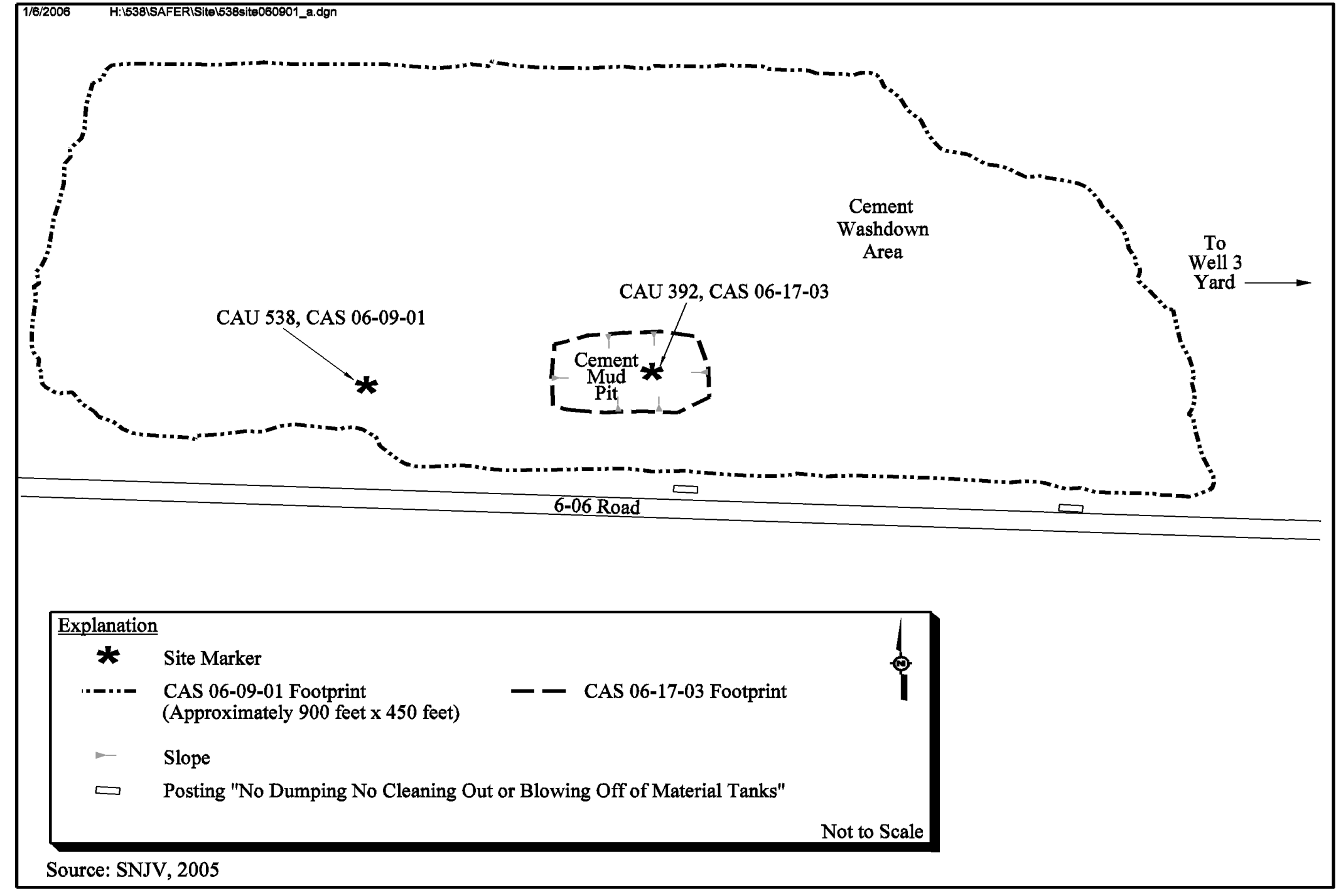

Figure 2-6

CAS 06-09-01, Cement Washdown, Site Layout 
pile and eventually hardened, creating the large cement washdown area identified as this CAS (BN, 2002). Two postings at the site read, "No Dumping No Cleaning Out or Blowing Off of Material Tanks" (SNJV, 2005).

In April 1991, REECo took over the cement operations at the Well 3 Yard and recovered all usable material from the cement washdown area at CAS 06-17-03 (CAU 392) and CAS 06-09-01 for road construction. The remaining materials consisted of hardened cement and cement dust covered with a hardened crust. In 1992, the surface cement pile at CAS 06-17-03 (CAU 392) was removed and sent to the Area $10 \mathrm{U}-10 \mathrm{C}$ Landfill. The waste remaining at the site consisted of cement chips and cement waste mixed and scattered throughout the surrounding vegetated area. In 2001, approximately 28.12 cubic yards $\left(\mathrm{yd}^{3}\right)$ of soil was removed from the bottom of the cement mud pit at CAS 06-17-03 (CAU 392) and was clean-closed under the Housekeeping Corrective Action Process (BN, 2002).

\subsubsection{Available Characterization Information}

Analytical Results - Characterization and verification samples were collected at CAS 06-17-03 (CAU 392) in 1997 and in 2001, respectively. In 1997, samples ERS00021 and ERS00022, as shown in Figure B.8-5, were collected at CAS 06-09-01 and CAS 06-17-03 (CAU 392), respectively, to determine whether COCs were present. Corrective Action Site 06-17-03 (CAU 392) is located within the boundary of CAS 06-09-01. Both samples were analyzed for VOCs, SVOCs, RCRA metals, TPH-DRO, gamma-emitters, and gross alpha and beta. Reported concentrations were below PALs (Bordelois, 1998).

In 2001, four waste characterization samples were collected from CAS 06-17-03 (CAU 392) and analyzed for RCRA metals and Toxicity Characteristic Leaching Procedure (TCLP) barium. Reported concentrations were below preliminary remediation goals (PRGs) and toxicity characteristics levels, respectively. An additional seven verification samples were collected at CAS 06-17-03 (CAU 392), after debris was removed from the CAS, and analyzed for RCRA metals. Reported concentrations were below PALs (BN, 2002). 


\subsection{Corrective Action Site 06-44-05, Diesel Spill From Tank \#38061}

Corrective Action Site 06-44-05 is located adjacent to the western side of the former Upper Monastery Building in Area 6. The building was demolished in 2005. The environmental concern at this CAS is stained soil located on the west side of the concrete building foundation. The site was originally identified during the preliminary investigation of CAU 120, CAS 06-01-03, Trailer-Mounted Diesel Tank 38061, and was described as diesel-impacted gravel beneath where an aboveground storage tank (AST) had been located (Mellington, 1996). This AST is no longer present at the site and was removed before December 1996; however, the exact date of removal is unknown. Historical records discuss the presence of a diesel spill in the former location of this AST. The Upper Monastery Building has been referred to as the Monastery Building, Building \#06-CP-311, and Building CP-311 throughout historical documentation. The building will be referred to as the Upper Monastery Building throughout this plan.

The impacted soil was previously defined by the presence of degraded sandbags surrounding a 13-by-9-ft area. Field visits conducted in 1998 and 2001 identified the spill as a 52-by-5-ft, red-brown stain leading from the removed AST's location, and also as a 12-inch (in.)-diameter faded rust-colored stain at the southeast corner of the rectangle of sandbags. As a result of demolishing the Upper Monastery Building, the CAS location was graded, and stained soil and sandbags are no longer visible.

Figure 2-7 shows the CAS with respect to roads and the nearby facilities in Area 6. Figure 2-8 shows the CAS layout boundary as it exists currently.

\subsubsection{History and Process Knowledge}

Historically, the Upper Monastery Building was used as an observation point for testing activities at Yucca Flat. During the last 25 to 30 years, the Upper Monastery Building has been used as a communications relay point and a storage facility for radio equipment. The AST \#0038061 was removed before 1996 and used to store diesel fuel for generators at the Upper Monastery Building. The gravel beneath the AST was documented to have been impacted by a diesel spill or leak from the AST (Mellington, 1996). 


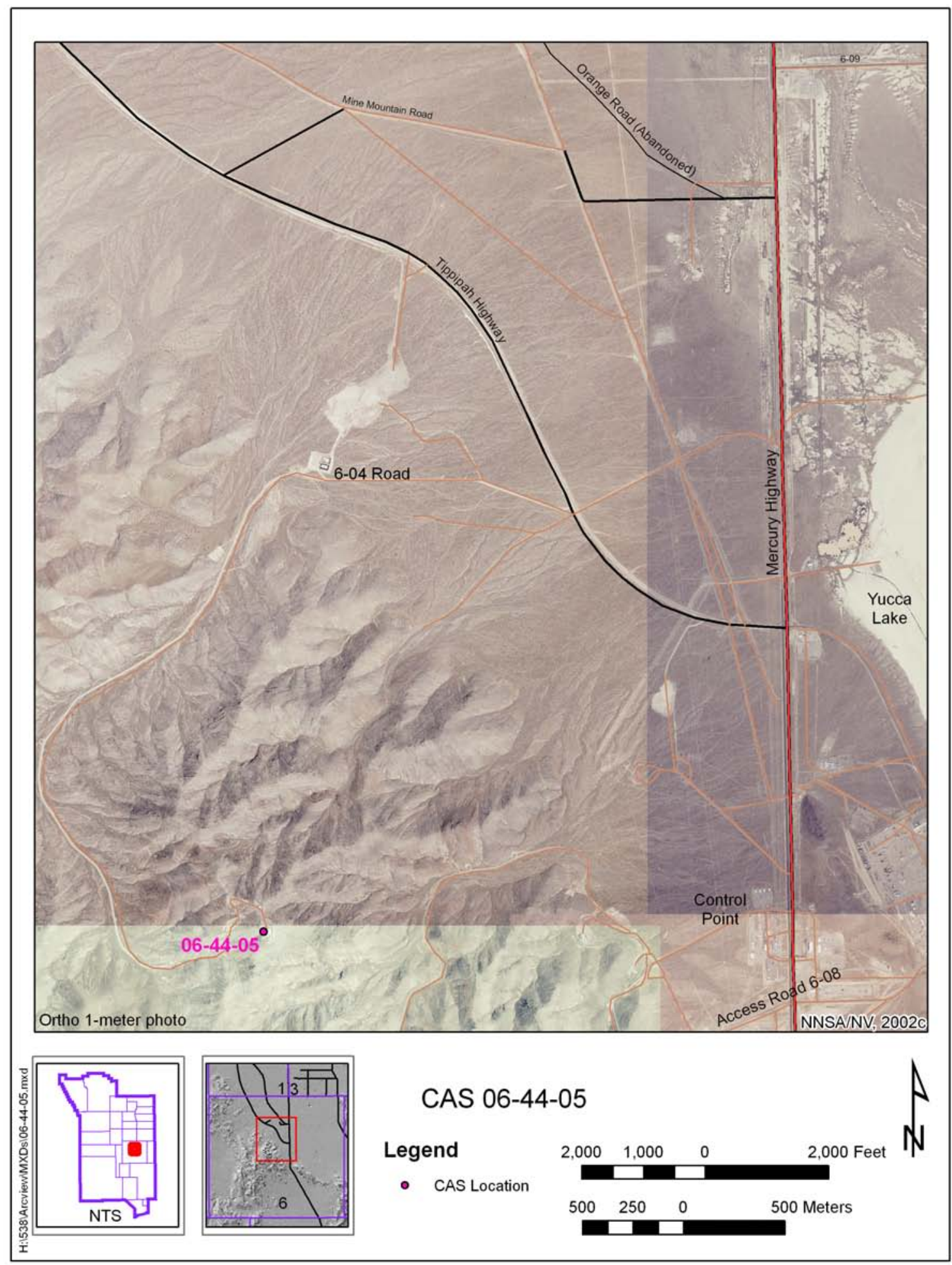

Figure 2-7

CAS 06-44-05, Diesel Spill From Tank \#38061, Location Map 


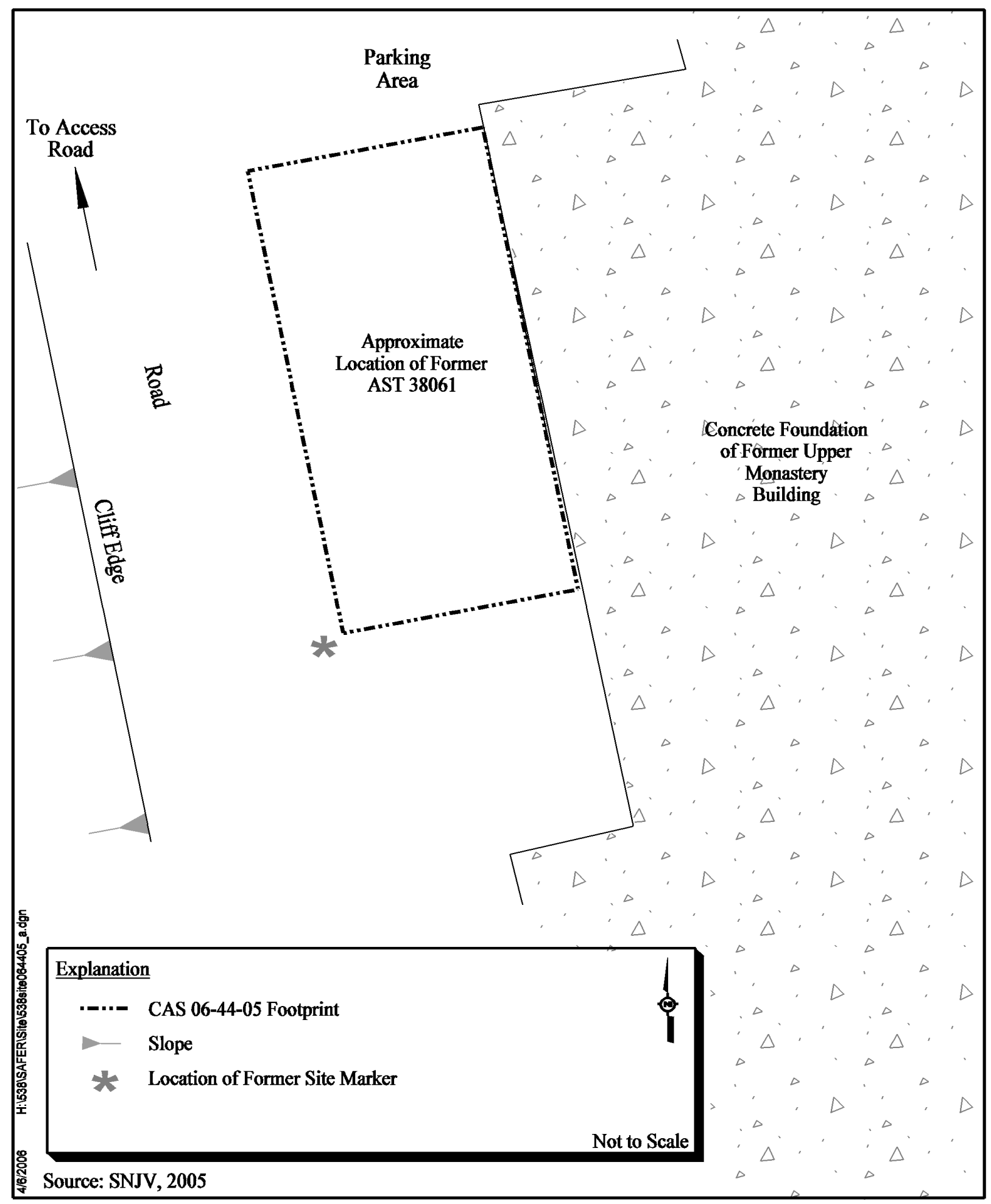

Figure 2-8

CAS 06-44-05, Diesel Spill From Tank \#38061, Site Layout 


\subsubsection{Available Characterization Information}

No analytical or geophysical survey results exist for this CAS; however, a non-site-specific aerial radiological survey of Area 6 was conducted in 1994. The survey did not show any detectable man-made radioactivity in the area near CAS 06-44-05. (BN, 1999a)

\subsection{Corrective Action Site 06-44-06, Spill Site with Hydrocarbons}

Corrective Action Site 06-44-06 is located adjacent to the CP-15 generator pad located north of Building CP-9 in the Area 6 Control Point (CP) South Facility. This CAS consists of releases of hydrocarbons adjacent to Underground Storage Tank (UST) 6-CP-9 and extending north approximately $60 \mathrm{ft}$.

During the removal of UST 6-CP-9, field crews observed stained soil at the northeast corner of the excavation. During the removal of UST 6-CP-9, a petroleum hydrocarbon release greater than 25 gallons (gal) was detected, and a notification of release was sent to NDEP. Excavation activities were limited because of the presence of subsurface utilities, and a non-FFACO land use restriction was established for this area. The remaining impacted soil within the use restricted area is addressed in this CAS. The use restriction is provided in Appendix C of this plan. The Nevada Division of Emergency Management (NDEM) assigned the release case No. 980624-2903, Tank 6-CP-9 at the NTS Area 6 Control and Data Acquisition Center (CADAC) Generator Pad (Sygitowicz, 1998). The hydrocarbon-impacted soil north of the former UST may have resulted from separate releases and will be investigated during the investigation of this CAS.

The boundaries encompassing the scope of the investigation at this site were defined by sample field-screening and analytical results reported in the CR for UST 6-CP-9 (DOE/NV, 1998) and the geo-coordinates identified in the associated land use restriction (Sygitowicz, 1998).

Figure 2-9 shows the CAS location with respect to the surrounding roads, buildings, and other physical features. Figure 2-10 shows the CAS boundaries and the physical layout. 


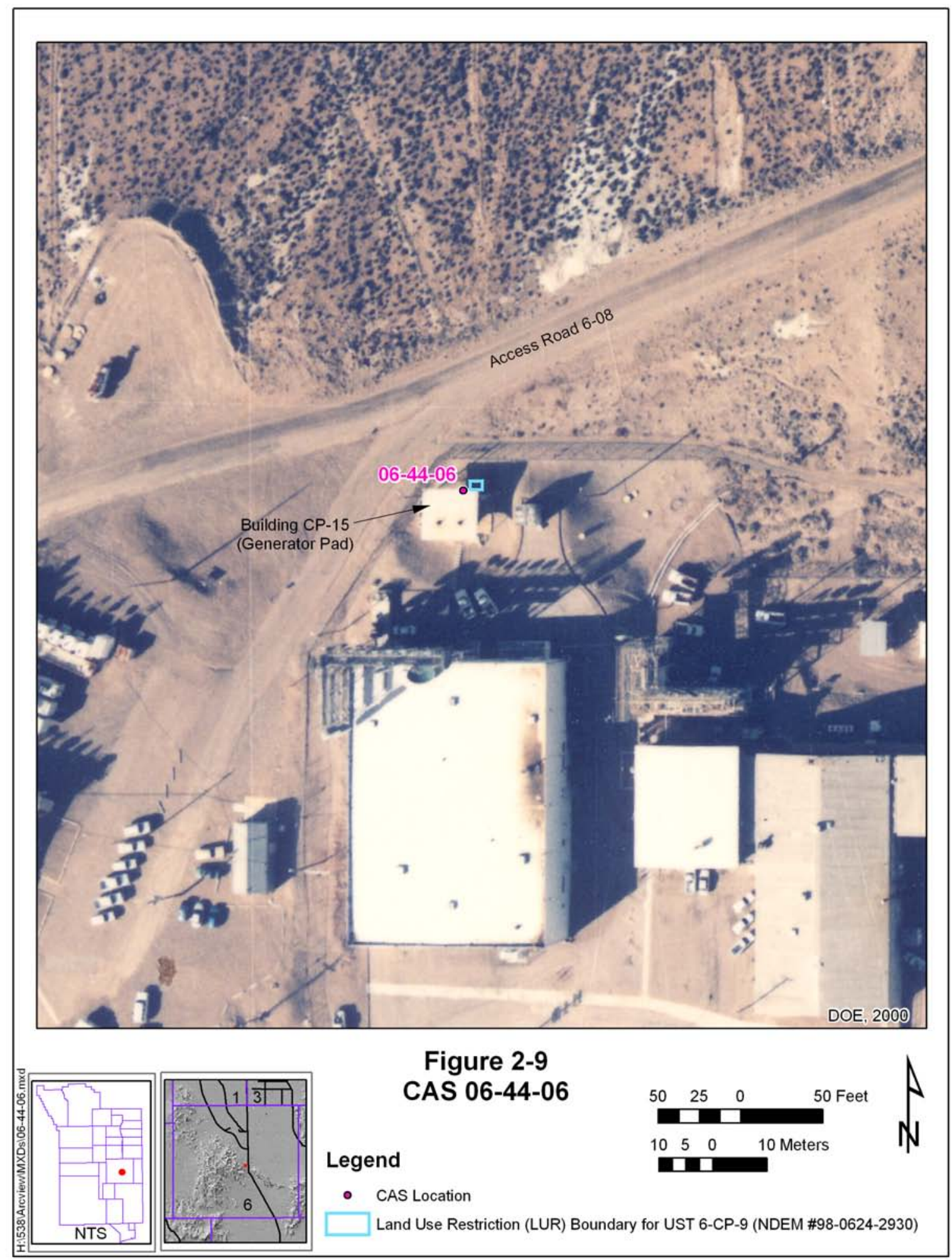

Figure 2-9

CAS 06-44-06, Spill Site with Hydrocarbons, Location Map 


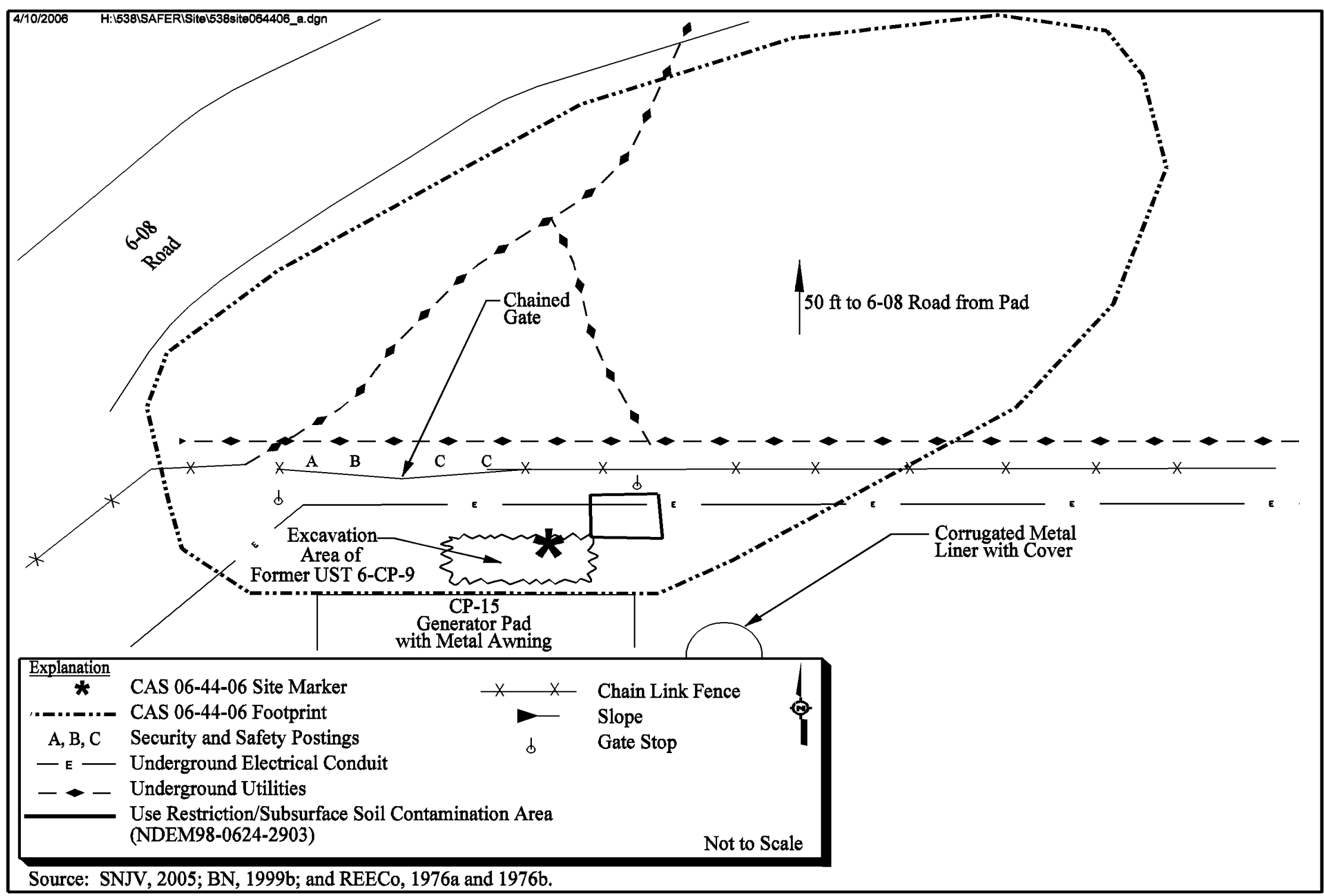

Figure 2-10

CAS 06-44-06, Spill Site with Hydrocarbons, Site Layout 


\subsubsection{History and Process Knowledge}

The UST 6-CP-9 was installed in 1980 and was removed on July 8, 1998. This 5,000-gal UST leaked diesel into the soil at the site. The cause of the release is described as personnel error and inattention to detail. Over a period of years, the UST was overfilled by personnel on a regular basis and leaked onto the surrounding soil (Sygitowicz, 1998).

As a result, it was recommended in the CR for UST 6-CP-9 that these areas of surface contamination be addressed under FFACO as a new CAS (DOE/NV, 1998).

The NDEP concurred that no further action was necessary at this site to close the UST 6-CP-9 site. As a result, the land use restriction located in Appendix $\mathrm{C}$ was issued and recorded in the Facilities Information Management System (FIMS) database (NNSA/NSO, 2006a).

\subsubsection{Available Characterization Information}

Analytical Results - Soil samples, as shown in Figure B.8-10, were collected in 1998 during the closure of UST 6-CP-9. Based on the analytical results from the sampling activities, $75 \mathrm{yd}^{3}$ of contaminated soil was identified and removed from the UST excavation; however, contamination northeast of the excavation could not be removed due to utilities and a fence (DOE/NV, 1998). Samples were collected downslope to the north and east of the former UST excavation from the surface and shallow subsurface soil. Analytical results of the soil samples indicated that TPH concentrations were less than 100 parts per million (ppm) to the west, south, and southwest of the UST excavation area; however, analytical results indicated that elevated TPH concentrations ranging from $330 \mathrm{ppm}$ at $10 \mathrm{ft}$ below ground surface (bgs) and $940 \mathrm{ppm}$ at $12 \mathrm{ft}$ bgs remain in the northeast corner of the excavation.

Four boreholes (CP9-1 through CP9-4) were drilled to the northeast, east, and north of the excavation area, respectively, to identify the lateral extent of petroleum hydrocarbon contamination. The TPH field-screening results (FSRs) for drill cuttings collected at $5 \mathrm{ft}$ bgs from boreholes CP9-1, CP9-2, and CP9-4 ranged between $217 \mathrm{ppm}$ and $426 \mathrm{ppm}$. The analytical results for TPH-DRO showed that the concentrations decreased to below $10 \mathrm{ppm}$ at $10 \mathrm{ft}$ bgs at boreholes CP9-1, CP9-2, CP9-3, and CP9-4. However, at $16 \mathrm{ft}$ bgs at CP9-3, the TPH-DRO concentration was 220 milligrams per kilogram (mg/kg), and the TPH FSR was 320 ppm at $19 \mathrm{ft}$ bgs. Borehole CP9-3 was drilled as close 
to the northeast corner of the excavation area as possible to define the vertical extent of TPH-DRO contamination in the subsurface; however, subsurface utilities and fencing hindered further drilling activities. As a result, a request for a Land Use Restriction for the area was submitted to and approved by the NDEP (DOE/NV, 1998) (see Appendix C).

Surface and shallow subsurface samples collected further downslope of the excavation showed TPH field-screening and/or analytical results exceeding $100 \mathrm{ppm}$ to a distance at approximately $60 \mathrm{ft}$ from the excavation (DOE/NV, 1998). These samples were collected between 0 to $0.5 \mathrm{ft}$ bgs, from 0.5 to $1.0 \mathrm{ft}$ bgs, from 2.0 to $3.0 \mathrm{ft}$ bgs, and from 3.0 to $4.0 \mathrm{ft}$ bgs, and field screened for TPH using the PetroFlag $^{\mathrm{TM}}$. The FSRs varied from less than $100 \mathrm{ppm}$ to greater than $100 \mathrm{ppm}$ between 0 and $0.5 \mathrm{ft}$ bgs and 0.5 and $1.0 \mathrm{ft}$ bgs. Concentrations of TPH between 3.0 and $4.0 \mathrm{ft}$ bgs were not detected in the samples (DOE/NV, 1998).

\subsection{Corrective Action Site 12-29-06, Spill Site}

Corrective Action Site 12-29-06 is located at the former Lineman's Shop at the intersection of Rainier Mesa Road and N-Tunnel Road in Area 12. This CAS consists of the following releases: (1) potentially contaminated soil adjacent to the perimeter of the building foundation, (2) a soil stain in a 19-by-9-ft area adjacent to the northwest section of the asphalt-covered concrete pad, and (3) potential polychlorinated biphenyl (PCB)-contaminated residue on the abandoned oil transformer south of Substation 12-2.

The site was first identified in the 1991 REECo document entitled, Nevada Test Site Inventory of Inactive and Abandoned Facilities and Waste Sites Areas 11-15 (REECo, 1991c).

Figure 2-11 shows the CAS location with respect to surrounding roads in Area 12. Figure 2-12 shows the CAS boundary and current site layout.

\subsubsection{History and Process Knowledge}

The site was originally identified as the condemned and abandoned Area 12 Lineman's Shop with potentially PCB-containing oil stains. This shop was condemned by REECo Safety before 1991 and was razed in May 2002. The building was used for storage of chemicals, used oil, and transformer oil. Oil stains were observed on the floor of the Lineman's Shop as well as outside the shop, under 


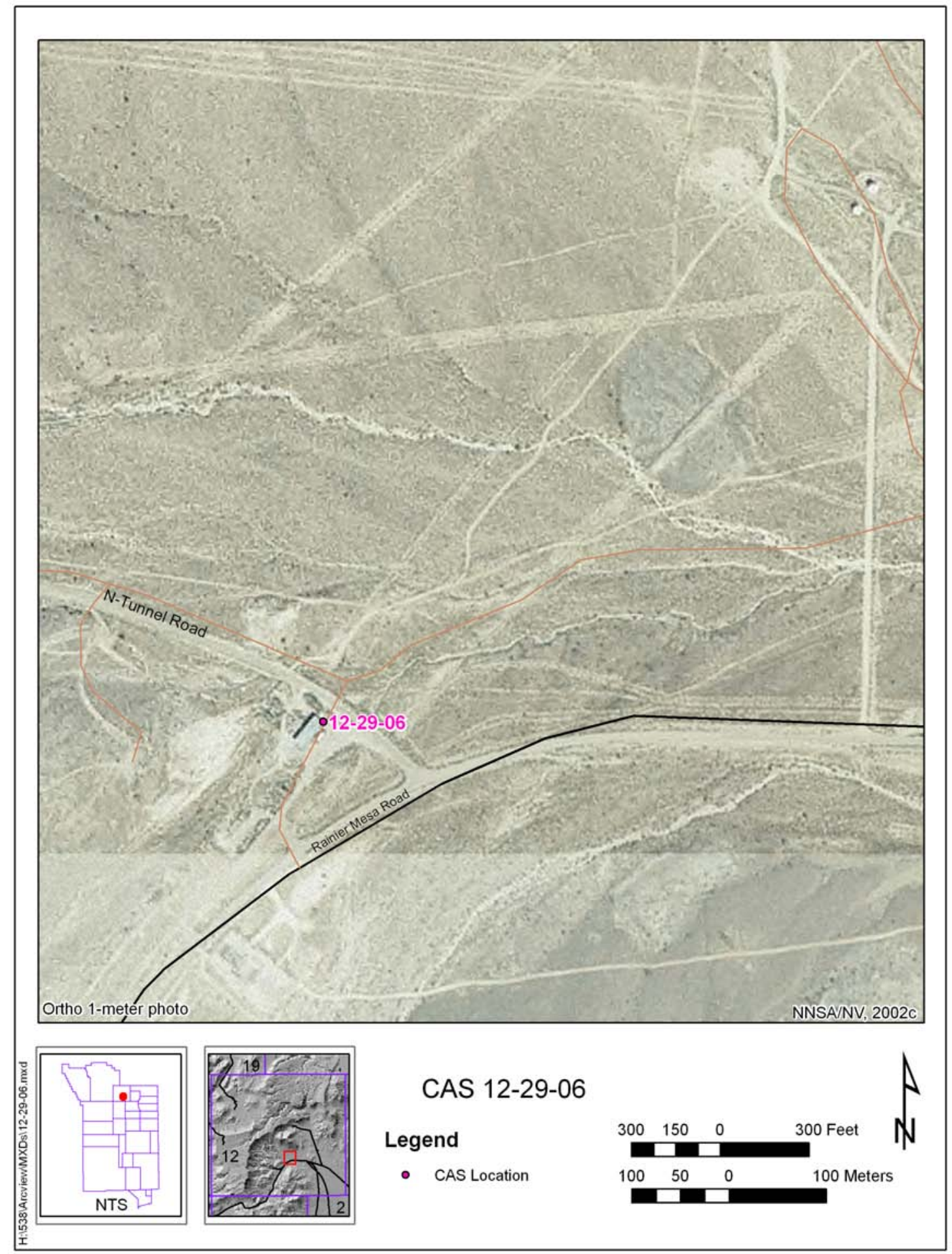

Figure 2-11

CAS 12-29-06, Spill Site, Location Map 


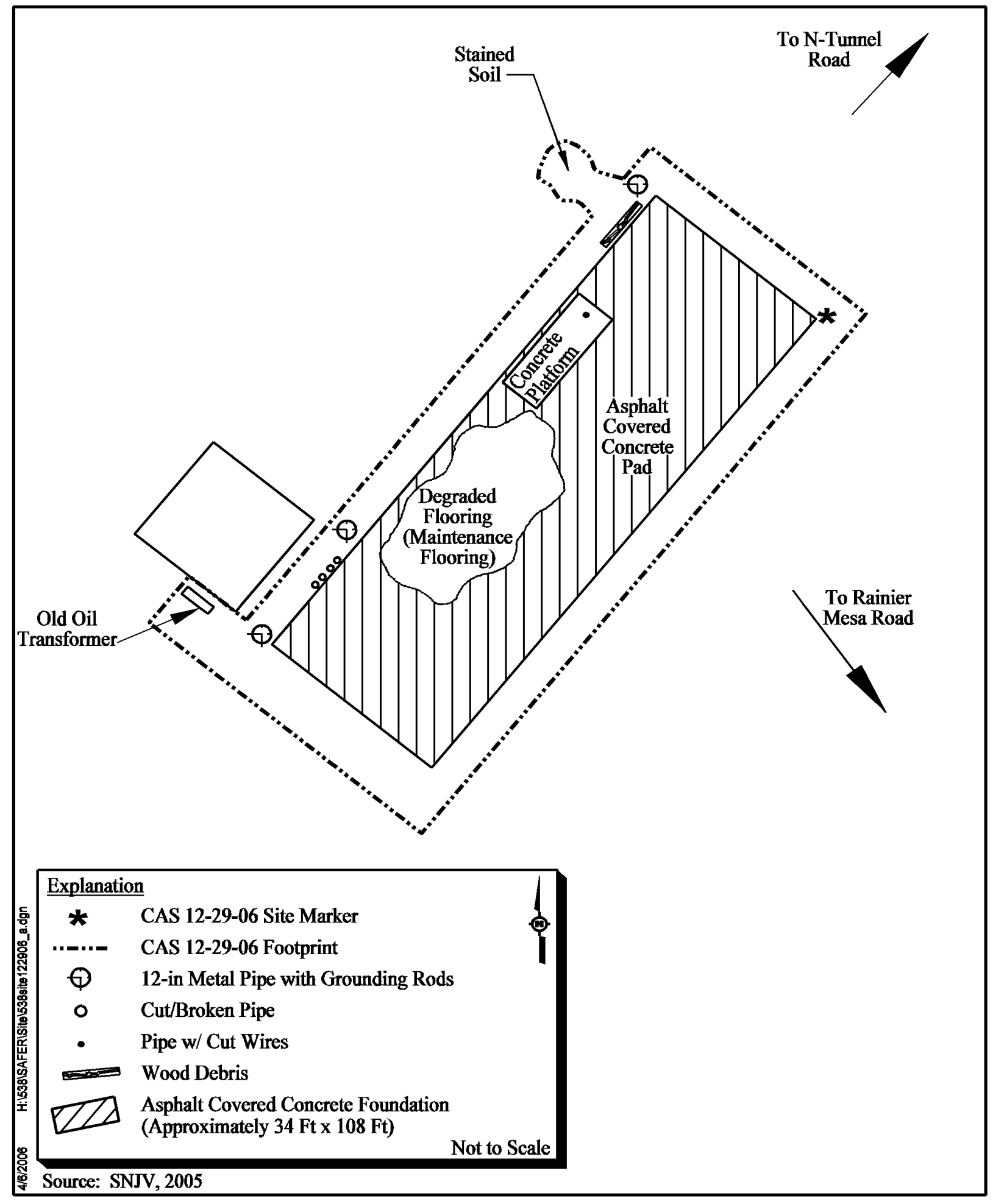

Figure 2-12

CAS 12-29-06, Spill Site, Site Layout 
stored transformers. On December 31, 1991, drum \#92287, I.H. \# 91TLH0629-7, containing solvents was removed from the site (REECo, 1992).

The Lineman's Shop is referred to in historical documentation as the Lineman's Shack or Shac (sic), the Storage Facility, the Storage Building, a chemical storage facility, a power maintenance facility, and Property \#998681. For the purposes of this document, the site will be referred to as the Lineman's Shop.

\subsubsection{Available Characterization Information}

Analytical Results - Two waste characterization samples (91JLH0625-6 and 91JLH0625-7) were collected on June 25, 1991, from the unknown contents of the Lineman's Shop at CAS 12-29-06 for waste characterization purposes. Sample 91JLH0625-6 was taken from a 5-gal, unmarked pail, and 91JLH0625-7 was taken from a 10-gal, unmarked pail. Samples were analyzed for total VOCs, PCBs, flashpoint, and gamma radiation levels (Harvey, 1991). Sample JLH0625-6 had a pH of 7.2. Sample 91JLH0625-7 had a pH of 2.31 and a flashpoint of 118 degrees Fahrenheit.

Tetrachloroethene (a.k.a. tetrachloroethylene and perchloroethene) was detected in sample 91JLH0625-7 at a concentration of 179 grams per liter $(\mathrm{g} / \mathrm{L})$.

Radiological Survey Results - A radiological survey was conducted in 2002 at a location within 500 $\mathrm{ft}$ of CAS 12-29-06. A total of 6,723 data points recorded over approximately $13,800 \mathrm{ft}^{2}$ had a mean gamma radiation emission rate of 221 counts per second (cps). This rate is below the mean undisturbed background gamma radiation emission rate of $226 \mathrm{cps}$. A maximum rate of $284 \mathrm{cps}$ was detected in a cluster and was attributed to factors such as the geometry of the detector face plane and the soil surface plane, varying soil types and geology, and residual radiological contamination. The survey report states that the site poses no risk to individuals (IT, 2002).

\subsection{Corrective Action Site 23-25-01, Oil Stains}

Corrective Action Site 23-25-01 is located in Area 23 at the former Building 146. This CAS consists of the following releases: (1) dark orange-brown stained soil beneath a thin layer of gravel measuring approximately 1 by $0.7 \mathrm{ft}$ wide at the north side of the concrete pad just east of a set of concrete 
saddles, and (2) soil surrounding the perimeter of the building foundation reported in historical documents as having heavy stains ranging in size from approximately 4 by $15 \mathrm{ft}$ to 5 by $30 \mathrm{ft}$.

The site was originally identified in the 1991 REECo document entitled, Nevada Test Site Inventory of Inactive and Abandoned Facilities and Waste Sites Areas 22-30 (REECo, 1991d). The site was identified as a cement pad in a parking lot approximately 40 yards north of Building 503 in Mercury. The heavy oil stains once described for this site in historical documents are no longer visible on the ground surface; therefore, the depth and volume of soil originally affected by the oil stain is unknown. The visible 1-by-0.7-ft soil stain north of the building foundation is believed to be a remnant of the heavy staining reported in historical documents.

The boundaries of the site were determined from historical documentation and aerial photographs that show heavy staining in the soil around the perimeter of the building foundation. The scope of the investigation at this CAS was determined during the DQO process and includes the observable staining adjacent to the north side of the building foundation, and the potentially impacted soils surrounding the perimeter of the building foundation. The former concrete building foundation is not included in the scope of the CAS.

Figure 2-13 shows the CAS location with respect to surrounding roads and buildings in Area 2 . Figure 2-14 shows the CAS boundaries and associated structures.

\subsubsection{History and Process Knowledge}

Engineering drawings from 1956 indicate that there was an existing Wash House (Building 146) located in the parking lot north of Buildings 501-508 (Men's Dormitories). The concrete pad is the foundation of this former Wash House, which was used as a laundry facility and measures 30 by $15 \mathrm{ft}$. Aerial photographs document the presence of an AST at the north side of this building. A set of concrete saddles are present on both the north and south sides of the building, indicating that two ASTs may have existed. The contents of the ASTs are unknown; however, an interview suggests propane may have been used to run the dryers and oil/fuel used to heat the building and water. 


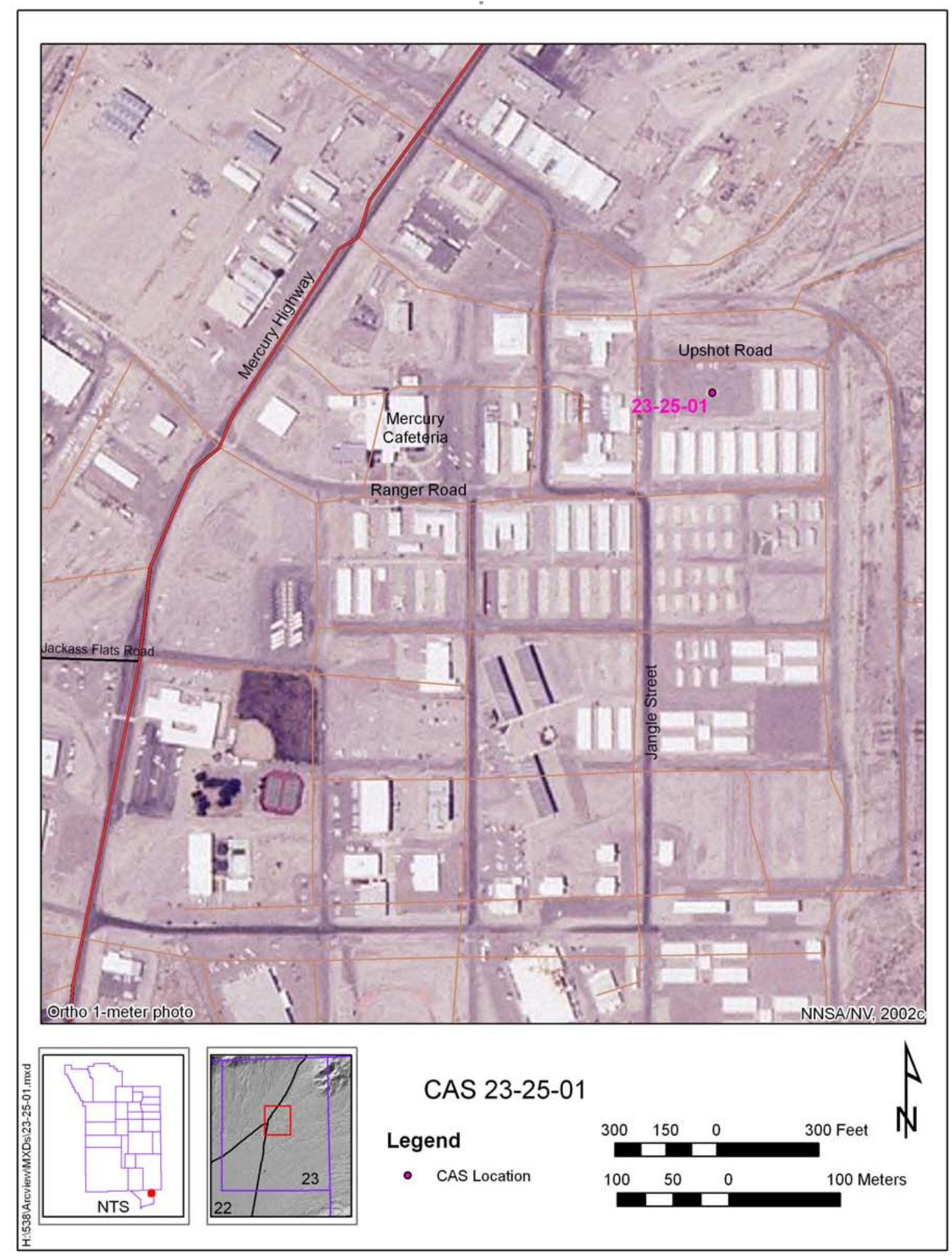

Figure 2-13

CAS 23-25-01, Oil Stains, Location Map 


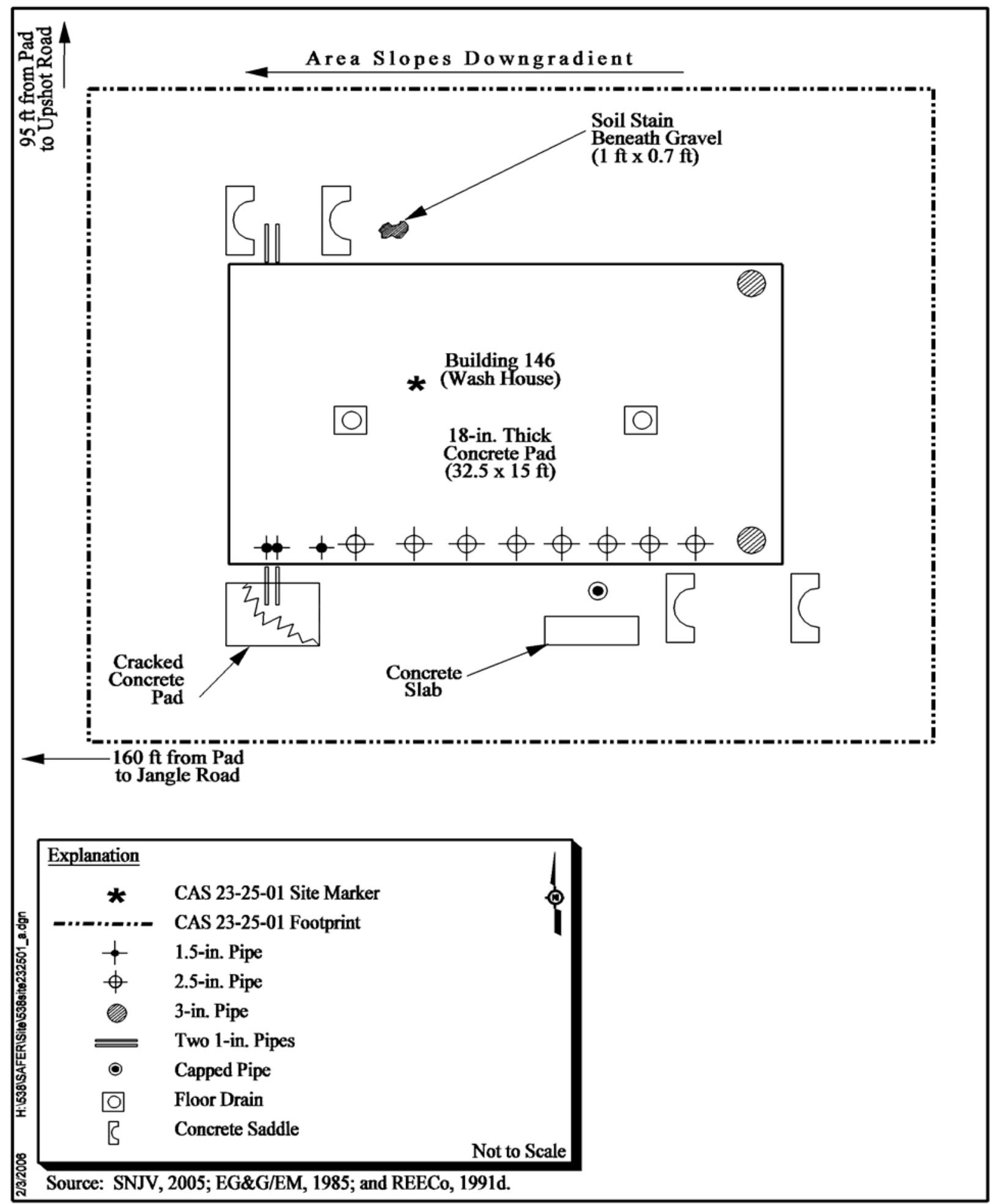

Figure 2-14

CAS 23-25-01, Oil Stains, Site Layout 
Aerial photographs and information from interviews indicate that the surrounding lot was used as a parking area where recreational vehicles and trailers were parked. The exact date of when Building 146 became inactive is uncertain; however, a series of aerial photographs suggest that this occurred between 1964 and 1969 when the entire lot was empty and graded over. However, aerial photographs document that the building had been demolished between 1969 and 1981, and that by 1981 the lot was again used to park vehicles.

The exact dates and cause of the releases are unknown; however, aerial photographs show what appears to be surface staining on the soil and concrete pad between 1981 and 1985. The 1985 aerial photograph shows the concentration of the dark areas heavier on the surface soil on the north, south, and west sides of the concrete pad. The source of the oil stains and whether they were the result of a single or multiple events is unknown.

\subsubsection{Available Characterization Information}

Analytical Results - In 1997, surface soil sample ERS00003, as shown in Figure B.8-12, was collected adjacent to the east tank saddle on the north side of the building foundation and analyzed for VOCs, SVOCs, RCRA metals, TPH-DRO, PCBs, gamma-emitting radionuclides, and gross alpha and beta. The preliminary TPH-DRO results exceeded $100 \mathrm{ppm}$. All other detected concentrations were below PALs (Forsgren, 1998).

Geophysical Survey Results - A geophysical survey was performed in September 2002 to determine the presence and location of a UST. The survey area measured approximately 23 by $116 \mathrm{ft}$ with the concrete pad of Building 146 located at the center of the site. The survey results indicate that there are no anomalies indicative of USTs, but there is abundant subsurface piping at this site (Shaw, 2002) that appears to be sewer lines, as shown in engineering drawings (REECo, 1956a, b, and c).

Radiological Survey Results - Radiological surveys were conducted in 1997, 2002, and 2005. The 1997 survey reported alpha and beta readings of 62.2 and 1,220 cps. The respective alpha and beta background reading at the site were $51.8 \mathrm{cps}$ and $1,420 \mathrm{cps}$ (IT, 1997). A radiological survey of CAS 23-02-02 (same as CAS 23-25-01) was conducted in July and August 2002. The 2002 survey detected elevated gamma radiation emission rate at $98 \mathrm{cps}$. The elevated gamma activity are attributed to geometry of the plane of the detector face with the plane of soil, varying soil types and 
geology, and residual radiological contamination (IT, 2002). Elevated alpha activity was detected during a static survey of the floor drains during a 2005 site visit. The elevated activity was determined to be the result of natural radon decay products and poses no radiological hazard to personnel (SNJV, 2005). 


\subsection{Data Quality Objectives}

\subsection{Summary of the DQO Analysis}

This section contains a summary of the DQO process that is presented in Appendix B. The DQO process is a strategic planning approach based on the scientific method that is designed to ensure that the data collected will provide sufficient and reliable information to identify, evaluate, and technically defend the recommendation for corrective actions (e.g., no further action, clean closure, or closure in place).

The DQO strategy for CAU 538 was developed during the DQO site visit and meeting conducted on December 14 and 15, 2005, respectively. The DQOs were developed to identify data needs, clearly define the intended use of the environmental data, and design a data collection program that will satisfy these purposes. During the DQO discussions for this CAU, the informational inputs or data needs to resolve problem statements and decision statements were documented.

The problem statement for CAU 538 is: "Existing information on the nature and extent of potential contamination is insufficient to evaluate and confirm closure of the individual CASs in CAU 538." To address this question, the resolution of two decision statements is required:

Decision I: "Does any COC exist in the environmental media within the CAS?" Any contaminant associated with a release from the CAS that is remaining at concentrations exceeding its corresponding FAL will be defined as a COC.

Decision II: "Is sufficient information available to confirm that closure objectives were met?" Sufficient information is defined to include:

- Information (e.g., analytical results) necessary to identifying the lateral and vertical extent of contamination in environmental media.

- Information (e.g., risk assessment) necessary to select the appropriate corrective action to complete closure of the site.

- Information (e.g., verification sample results) necessary to confirm that the closure alternative objectives were met. 
The Decision I COPCs and targeted analytes identified for each CAS are listed in Table 3-1. The analytes that are reported for each analysis are listed in Table 3-2. Analyses for waste characterization (e.g., TCLPs, tritium, gross alpha and beta) are not listed in Table 3-2. Decision II samples will be submitted for the analysis of all unbounded COCs. In addition, samples will be submitted for analyses as needed to support waste management or health and safety decisions.

The data quality indicators (DQIs) of precision, accuracy, representativeness, completeness, comparability, and sensitivity needed to satisfy DQO requirements are discussed in Section 7.2. Laboratory data will be assessed in the CR to confirm or refute the CSM and determine whether the DQO data needs were met.

\subsection{Results of the DQO Analysis}

\subsubsection{Action Level Determination and Basis}

The PALs presented in this section are to be used for site screening purposes. They are not intended to be used as FALs. However, they are useful in screening out analytes that are not present in sufficient concentrations to warrant further evaluation and, therefore, streamline the consideration of remedial alternatives. The process that will be used to move from PALs to FALs is that specified by Nevada Administrative Code (NAC) 445A.22705 (NAC, 1997), which stipulates that determination of FALs shall be established by an evaluation of the site based on the risk to public health and the environment. This evaluation will be conducted using Method E1739-95, adopted by the American Society for Testing and Materials (ASTM) (ASTM, 1995).

The ASTM's risk-based corrective action (RBCA) process, summarized in Figure 3-1, uses a tiered approach to data collection and analysis in supporting decisions on site assessment and response to contamination. This process includes a provision for conducting an interim remedial action if necessary and/or appropriate. The decision to conduct an interim action may be made at any time during the investigation and at any level (tier) of analysis. Concurrence of the decision makers listed in Section B.2.1 will be obtained before any interim action is implemented. Evaluation of DQO decisions will be based on conditions at the site following completion of any interim actions. Any interim actions conducted will be reported in the CR. 
Table 3-1

Contaminants of Potential Concern and Targeted Analytes for CAU 538 Corrective Action Sites ${ }^{a}$

\begin{tabular}{|c|c|c|c|c|c|c|c|}
\hline $\mathrm{COPC}^{\mathrm{b}}$ & $\begin{array}{l}\text { Targeted } \\
\text { Analytes }^{c}\end{array}$ & $\begin{array}{c}\text { CAS } \\
\text { 02-21-01 }\end{array}$ & $\begin{array}{c}\text { CAS } \\
\text { 03-25-04 }\end{array}$ & $\begin{array}{c}\text { CAS } \\
06-44-05\end{array}$ & $\begin{array}{c}\text { CAS } \\
06-44-06\end{array}$ & $\begin{array}{c}\text { CAS } \\
12-29-06\end{array}$ & $\begin{array}{c}\text { CAS } \\
\text { 23-25-01 }\end{array}$ \\
\hline \multirow[t]{9}{*}{ VOCs } & & $x$ & $x$ & $x$ & $x$ & $x$ & $x$ \\
\hline & $\begin{array}{c}\text { 1, 3, 5- } \\
\text { Trimethylbenzene }^{d}\end{array}$ & $x$ & $\mathbf{x}$ & $x$ & $x$ & $\mathbf{x}$ & $\mathbf{x}$ \\
\hline & Benzene $^{d}$ & $x$ & $x$ & $x$ & $x$ & $x$ & $x$ \\
\hline & Ethylbenzene $^{d}$ & $x$ & $x$ & $x$ & $x$ & $\mathbf{x}$ & $\mathbf{x}$ \\
\hline & n-Butylbenzene ${ }^{d}$ & $x$ & $x$ & $x$ & $x$ & $x$ & $x$ \\
\hline & n-Propylbenzene ${ }^{d}$ & $x$ & $x$ & $x$ & $x$ & $x$ & $x$ \\
\hline & Tetrachloroethylene & N/A & N/A & N/A & N/A & $x$ & N/A \\
\hline & Toluene $^{d}$ & $x$ & $x$ & $x$ & $x$ & $x$ & $x$ \\
\hline & Total Xylene $^{d}$ & $x$ & $x$ & $x$ & $x$ & $x$ & $x$ \\
\hline \multirow[t]{5}{*}{ SVOCs } & & $x$ & $x$ & $\mathbf{x}$ & $x$ & $\mathbf{x}$ & $x$ \\
\hline & 2-Methylnaphthalene ${ }^{d}$ & $x$ & $x$ & $x$ & $x$ & $x$ & $x$ \\
\hline & Benzo(a)anthracene ${ }^{d}$ & $x$ & $x$ & $x$ & $x$ & $x$ & $x$ \\
\hline & Benzo(a)pyrene ${ }^{d}$ & $\mathbf{x}$ & $x$ & $x$ & $x$ & $x$ & $x$ \\
\hline & Naphthalene $^{d}$ & $x$ & $x$ & $x$ & $x$ & $x$ & $x$ \\
\hline RCRA Metals $^{\mathrm{e}}$ & & $x$ & $x$ & $x$ & $x$ & $x$ & $x$ \\
\hline $\mathrm{TPH}$ & TPH-DRO ${ }^{f}$ & $x$ & $x$ & $x$ & $x$ & $x$ & $x$ \\
\hline PCBs & PCBs & N/A & N/A & N/A & N/A & $x$ & N/A \\
\hline \multicolumn{2}{|c|}{ Pesticides $^{g}$} & N/A & $x$ & $x$ & $\mathbf{x}$ & $x$ & $x$ \\
\hline \multicolumn{2}{|c|}{ Gamma-Emitting Radionuclides } & $x$ & $x$ & $\mathbf{x}$ & $\mathbf{x}$ & $\mathbf{x}$ & N/A \\
\hline
\end{tabular}

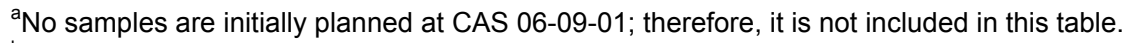

${ }^{\mathrm{b}} \mathrm{COPCs}$ are contaminants that could be potentially present.

${ }^{\mathrm{c}}$ Targeted analytes are present or are reasonably suspected to be present and are required to meet a completeness criteria of 100 percent.

dWill only be considered a targeted analyte for samples that exceed the PALs for TPH (NNSA/NSO, 2006).

${ }^{\text {e} B e r y l l i u m ~ w i l l ~ b e ~ r e q u e s t e d ~ w i t h ~ R C R A ~ m e t a l s ~ f o r ~ a d m i n i s t r a t i v e ~ p u r p o s e s ~ s u c h ~ a s ~ o b t a i n i n g ~ b a c k g r o u n d ~ b e r y l l i u m ~ l e v e l s . ~}$

${ }^{f} \mathrm{TPH}$ or the hazardous constituents of TPH.

${ }^{9}$ Pesticide analysis will only be conducted on soil samples collected within $10 \mathrm{ft}$ of a building foundation.

$\mathrm{DRO}=$ Diesel-range organics

$\mathrm{ft}=$ Foot

$\mathrm{N} / \mathrm{A}=$ Not applicable

$\mathrm{PAL}=$ Preliminary action level

$\mathrm{PCB}=$ Polychlorinated biphenyl

RCRA = Resource Conservation and Recovery Act

SVOC $=$ Semivolatile organic compound

$\mathrm{TPH}=$ Total petroleum hydrocarbons

$\mathrm{VOC}=$ Volatile organic compound 
Table 3-2

Analytes Reported by Analytical Methods

\begin{tabular}{|c|c|c|c|c|c|c|c|}
\hline \multicolumn{2}{|c|}{ VOC } & SVOC & TPH & PCB & Metals & Pesticides & Radionuclides \\
\hline $\begin{array}{l}\text { 1,1,1-Trichloroethane } \\
\text { 1,1,1,2-Tetrachloroethane } \\
\text { 1,1,2,-Tetrachloroethane } \\
\text { 1,1,2-Trichloroethane } \\
\text { 1,1-Dichloroethane } \\
\text { 1,1-Dichloroethene } \\
\text { cis-1,2-Dichloroethene } \\
\text { 1,2-2ichloroethane } \\
\text { 1,2-Dichloropropane } \\
\text { 1,2,4-Trichlorobenzene } \\
\text { 1,2,4-Trimethylbenzene } \\
\text { 1,2-Dibromo-3-chloropropane } \\
\text { 1,3,5-Trimethylbenzene } \\
\text { 1,4--Dioxane } \\
\text { 2-Butanone } \\
\text { 2-Chlorotoluene } \\
\text { 2-Hexanone } \\
\text { 4-Methyl-2-pentanone } \\
\text { Acetone } \\
\text { Acetonitrile } \\
\text { Allyl chloride } \\
\text { Benzene } \\
\text { Bromodichloromethane } \\
\text { Bromoform } \\
\text { Bromomethane } \\
\text { Carbon disulfide } \\
\text { Carbon tetrachloride } \\
\text { Chlorobenzene } \\
\text { Chloroethane } \\
\text { Chloroform } \\
\text { Chloromethane } \\
\text { Chloroprene } \\
\text { Dibromochloromethane } \\
\text { Dichlorodifluoromethane } \\
\text { Ethyl methacrylate } \\
\text { Ethylbenzene } \\
\text { Isobutyl alcohol } \\
\text { Isopropylbenzene } \\
\text { m-Dichlorobenzene (1,3) } \\
\text { Methacrylonitrile } \\
\text { Methyl methacrylate }\end{array}$ & $\begin{array}{l}\text { Methylene chloride } \\
\text { N-Butylbenzene } \\
\text { N-Propylbenzene } \\
\text { o-Dichlorobenzene } \\
(1,2) \\
\text { p-Dichlorobenzene } \\
(1,4) \\
\text { p-isopropyltoluene } \\
\text { sec-Butylbenzene } \\
\text { Styrene } \\
\text { tert-Butylbenzene } \\
\text { Tetrachloroethene } \\
\text { Toluene } \\
\text { Total Xylenes } \\
\text { Trichloroethene } \\
\text { Trichlorofluoromethane } \\
\text { Vinyl acetate } \\
\text { Vinyl chloride }\end{array}$ & $\begin{array}{l}\text { 2,3,4,6-Tetrachlorophenol } \\
\text { 2,4-Dimethylphenol } \\
\text { 2,4-Dinitrotoluene } \\
\text { 2,4,5-Trichlorophenol } \\
\text { 2,4,6-Trichlorophenol } \\
\text { 2-Chlorophenol } \\
\text { 2-Methylnaphthalene } \\
\text { 2-Methylphenol } \\
\text { 2-Nitrophenol } \\
\text { 3-Methylphenol } \\
\text { 4-Chloroaniline } \\
\text { 4-Methylphenol } \\
\text { 4-Nitrophenol } \\
\text { Acenaphthene } \\
\text { Acenaphthylene } \\
\text { Aniline } \\
\text { Anthracene } \\
\text { Benzo(a)anthracene } \\
\text { Benzo(a)pyrene } \\
\text { Benzo(b)fluoranthene } \\
\text { Benzo(g,h,i)perylene } \\
\text { Benzo(k)fluoranthene } \\
\text { Benzoic Acid } \\
\text { Benzyl Alcohol } \\
\text { Bis(2-ethylhexyl) phthalate } \\
\text { Butyl benzyl phthalate } \\
\text { Carbazole } \\
\text { Chrysene } \\
\text { Dibenzo(a,h)anthracene } \\
\text { Dibenzofuran } \\
\text { Diethyl Phthalate } \\
\text { Dimethyl Phthalate } \\
\text { Di-n-butyl Phthalate } \\
\text { Di-n-octyl Phthalate } \\
\text { Fluoranthene } \\
\text { Fluorene } \\
\text { Hexachlorobenzene } \\
\text { Hexachlorobutadiene } \\
\text { Hexachloroethane } \\
\text { Indeno(1,2,3-cd)pyrene } \\
\text { Naphthalene } \\
\text { Nitrobenzene } \\
\text { N-Nitroso-di-n-propylamine } \\
\text { Pentachlorophenol } \\
\text { Phenanthrene } \\
\text { Phenol } \\
\text { Pyrene } \\
\text { Pyridine } \\
\end{array}$ & $\begin{array}{l}\text { TPH } \\
\text { (Diesel-Range Organics } \\
\text { and Gasoline-Range } \\
\text { Organics) }\end{array}$ & $\begin{array}{l}\text { Aroclor } 1061 \\
\text { Aroclor } 1221 \\
\text { Aroclor } 1232 \\
\text { Aroclor } 1242 \\
\text { Aroclor } 1248 \\
\text { Aroclor } 1254 \\
\text { Aroclor } 1260 \\
\text { Aroclor } 1268\end{array}$ & $\begin{array}{l}\text { Arsenic } \\
\text { Barium } \\
\text { Beryllium } \\
\text { Cadmium } \\
\text { Chromium } \\
\text { Lead } \\
\text { Mercury } \\
\text { Selenium } \\
\text { Silver }\end{array}$ & $\begin{array}{l}\text { 4,4'-DDD } \\
\text { 4,4'-DDE } \\
\text { 4,'-DDT } \\
\text { Aldrin } \\
\text { Alpha-BHC } \\
\text { Alpha-Chlordane } \\
\text { Beta-BHC } \\
\text { Chlordane (Technical) } \\
\text { Delta-BHC } \\
\text { Dieldrin } \\
\text { Endosulfan I } \\
\text { Endosulfan II } \\
\text { Endosulfan Sulfate } \\
\text { Endrin } \\
\text { Endrin Aldehyde } \\
\text { Edrin Ketone } \\
\text { Gamma-BHC } \\
\text { Gamma-Chlordane } \\
\text { Heptachlor } \\
\text { Heptachlor Epoxide } \\
\text { Methoxychlor } \\
\text { Toxaphene }\end{array}$ & 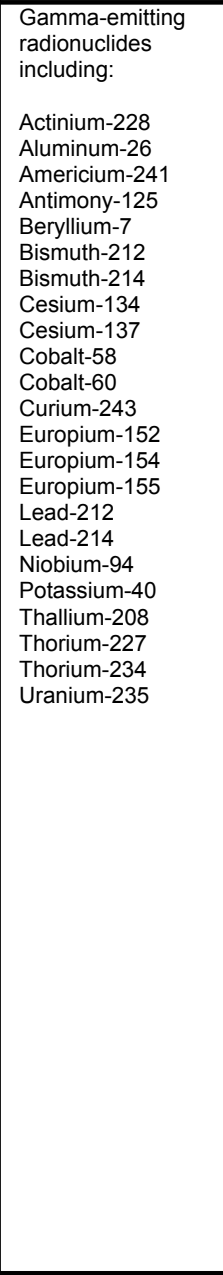 \\
\hline
\end{tabular}




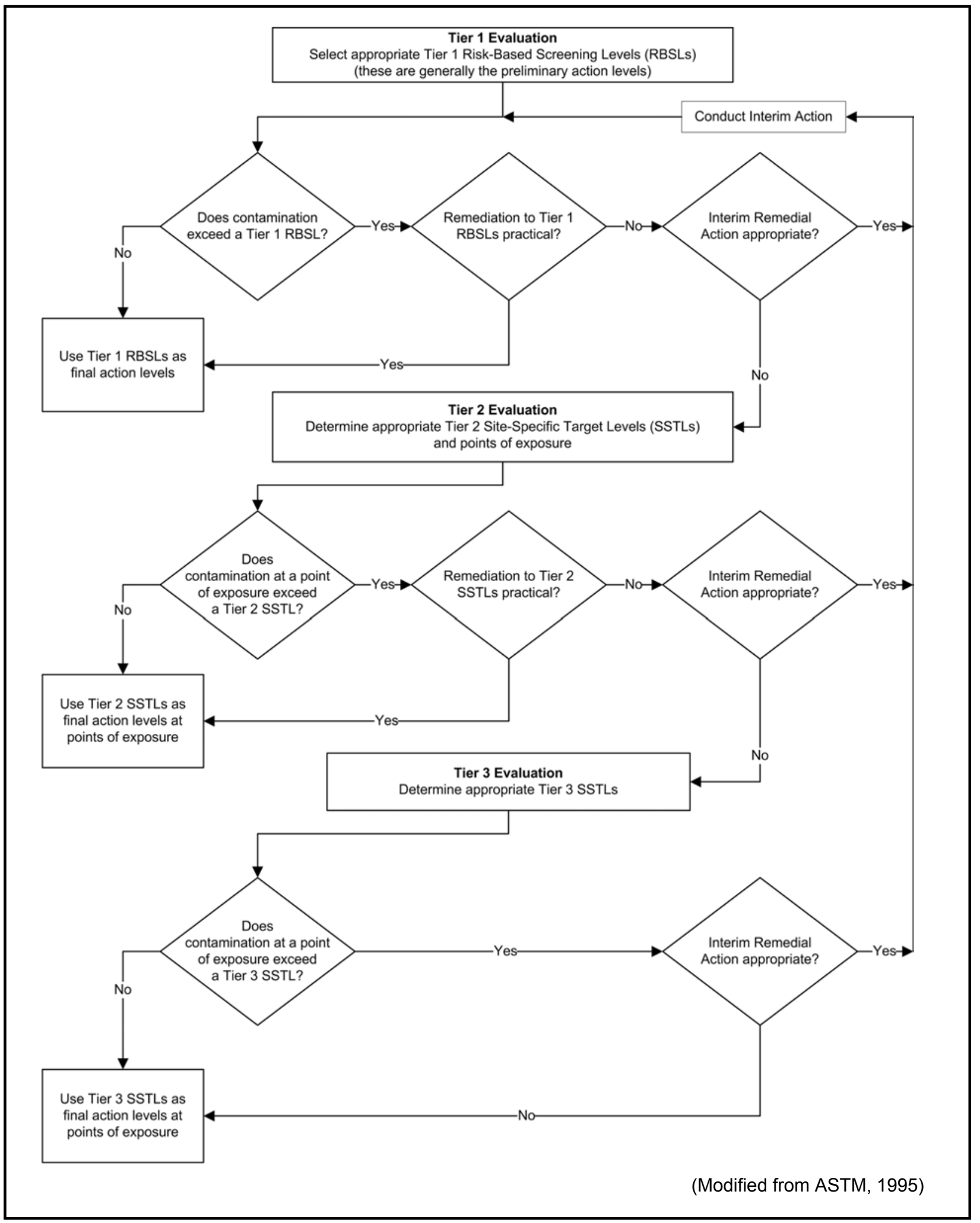

Figure 3-1

Process Used to Move Preliminary Action Levels to Final Action Levels 
The RBCA procedure defines three tiers or levels of evaluation involving increasingly sophisticated levels of analyses.

- Tier 1 - sample results from source areas (highest concentrations) compared to PALs based on generic (non-site-specific) conditions

- $\quad$ Tier 2 - sample results from exposure points compared to site-specific target levels (SSTLs) calculated using site-specific inputs and Tier 1 formulas

- Tier 3 - sample results from exposure points compared to SSTLs and points of compliance calculated using chemical fate/transport and probabilistic modeling

A Tier 1 evaluation will be conducted to determine whether contaminant levels satisfy the criteria for a quick regulatory closure or warrant a more site-specific assessment. This is accomplished by comparing individual source area contaminant concentration results to PALs. The PALs are a tabulation of chemical- and radioisotope-specific (but not site-specific) screening levels based on potential exposure pathways, media (i.e., soil, water, and air), and potential exposure scenarios using risk information derived from the Integrated Risk Information System (IRIS) Database (EPA, 2001) or a dose constraint of 25 millirem per year (mrem/yr). If remediation to Tier 1 action levels (PALs) is not practicable, a Tier 2 evaluation may be conducted. Rationale and justification for using a Tier 2 evaluation will be presented in the CR.

If appropriate, a Tier 2 evaluation may be conducted by calculating Tier 2 SSTLs using site-specific information as inputs to the same or similar methodology used to calculate Tier 1 action levels. The Tier 2 SSTLs are then compared to individual sample results from reasonable points of exposure (as opposed to the source areas as is done in Tier 1) on a point-by-point basis. Total TPH concentrations will not be used for risk-based decisions under Tier 2 or Tier 3. Rather, the individual hazardous constituents of TPH will be compared to the SSTLs (Sections 6.4.3 and X1.4 of ASTM, 1995).

Alternatively, the Tier 2 RBCA process SSTLs may be compared to the predicted concentration or activity of the contaminant at the point of exposure based on attenuation from the source using relatively simplistic mathematical models. Points of exposure are defined as those locations at which an individual or population may come in contact with a COC originating from a CAS. If a Tier 2 evaluation is conducted, the calculations used to derive the SSTLs and the contaminant attenuation calculations will be provided as an appendix to the CR. If remediation to Tier 2 SSTLs is not 
practicable, a Tier 3 evaluation may be conducted. Rationale and justification for using a Tier 3 evaluation will be presented in the CR.

If appropriate, a Tier 3 evaluation may be conducted by calculating Tier 3 SSTLs on the basis of more sophisticated risk analyses using methodologies described in Method E1739-95 that consider site-, pathway-, and receptor-specific parameters. Tier 3 evaluation is much more complex than Tiers 1 and 2 because it may include additional site characterization, probabilistic evaluations, and sophisticated chemical fate/transport models. The Tier 3 SSTLs are then compared to the 95 percent upper confidence limit of the mean of sample results from reasonable point(s) of exposure (as opposed to individual sample results as is done in Tier 2). Contaminant concentrations exceeding Tier 3 SSTLs require corrective action. If a Tier 3 evaluation is conducted, the calculations used to derive the SSTLs and the upper confidence limit of the means will be provided as an appendix to the CR.

The FALs (along with the basis for their selection) will be proposed in the CR, where they will be compared to laboratory results in the evaluation of potential corrective actions.

\subsubsection{Chemical PALs}

Except as noted herein, the chemical PALs are defined as the U.S. Environmental Protection Agency (EPA) Region 9 Risk-Based Preliminary Remediation Goals for chemical constituents in industrial soils (EPA, 2004). Background concentrations for RCRA metals will be used instead of PRGs when natural background concentrations exceed the PRG, as is often the case with arsenic on the NTS. Background is considered the mean plus two standard deviations of the mean for sediment samples collected by the Nevada Bureau of Mines and Geology throughout the Nevada Test and Training Range (formerly the Nellis Air Force Range) (NBMG, 1998; Moore, 1999). For detected chemical COPCs without established PRGs that have toxicity and carcinogenicity data listed in the EPA IRIS database (EPA, 2001), the protocol used by the EPA Region 9 in establishing PRGs (or similar) will be used to establish PALs. If used, this process will be documented in the CR.

\subsubsection{Total Petroleum Hydrocarbons PALs}

The PAL for TPH is 100 ppm as listed in NAC 445A.2272 (NAC, 2005). 


\subsubsection{Radionuclide PALs}

The PALs for radiological contaminants (other than tritium) are based on the National Council on Radiation Protection and Measurement Report No. 129 recommended screening limits for construction, commercial, industrial land-use scenarios using a $25 \mathrm{mrem} / \mathrm{yr}$ dose constraint (NCRP, 1999; Murphy, 2004) and the generic guidelines for residual concentration of radionuclides in DOE Order 5400.5 (DOE, 1993). These PALs are based on the Construction, Commercial, Industrial land-use scenario provided in the guidance and are appropriate for the NTS based on the exposure scenarios as presented in Section B.2.2.6.

The PAL for tritium is based on the Underground Test Area (UGTA) Project limit of 400,000 pCi/L for discharge of water containing tritium to an infiltration basin/area (NNSA/NV, 2002a).

Solid media such as concrete and/or structures may pose a potential radiological exposure risk to site workers if contaminated. The radiological PAL for solid media will be defined as the unrestricted-release criteria defined in the NV/YMP Radiological Control (RadCon) Manual (NNSA/NSO, 2005b).

\subsubsection{Hypothesis Test}

Only laboratory analytical results that meet the requirements of the Industrial Sites Quality Assurance Project Plan (QAPP) (NNSA/NV, 2002b) will be used to resolve DQO decisions. The null hypothesis is that closure objectives have not been met. Sufficient evidence to prove the null hypothesis wrong is:

- The identification of the lateral and vertical extent of COC contamination in media, if present.

- Sufficient information to properly dispose of investigation-derived waste (IDW) and remediation waste.

\subsubsection{Statistical Model}

Because individual sample results, rather than an average concentration, will be used to compare to FALs, statistical methods to generate site characteristics will not be necessary. Section 0.4.4 of the EPA Data Quality Objectives Process for Hazardous Waste Site Investigations (EPA, 2000) guidance (QA/G-4HW) states that the use of statistical methods may not be warranted by program guidelines 
or site-specific sampling objectives. The need for statistical methods is dependent upon the decisions being made. Section 7.1 of the EPA QA/G-4HW guidance states that a nonprobabilistic (judgmental) sampling approach is developed when there is sufficient information on the contamination sources and history to develop a valid CSM and to select specific sampling locations. This approach is used to confirm the existence of contamination at specific locations and provide information (such as extent of contamination) about specific areas of the site.

\subsubsection{Design Description/Option}

A judgmental sampling approach will be used to collect samples from the locations most likely to contain COCs, if present within each CAS. Sample locations will be determined based on process knowledge, previously acquired data, or the field screening and biasing factors listed in Section 4.2. Section 7.1 of the EPA QA/G-4HW guidance states that a non-probabilistic (judgmental) sampling approach is developed when there is sufficient information on the contamination sources and history to develop a valid CSM and to select specific sampling locations.

\subsubsection{Conceptual Site Model and Drawing}

The CSM describes the most probable scenario for current conditions at each site and defines the assumptions that are the basis for identifying the future land use, contaminant sources, release mechanisms, migration pathways, exposure points, and exposure routes. The CSM is also used to support appropriate sampling strategies and data collection methods. The CSM was developed for CAU 538 using information from the physical setting, potential contaminant sources, release information, historical background information, knowledge from similar sites, and physical and chemical properties of the potentially affected media and COPCs. Figure 3-2 depicts a tabular representation of the CSM, while Figure 3-3 depicts a graphical representation of the CSM. 


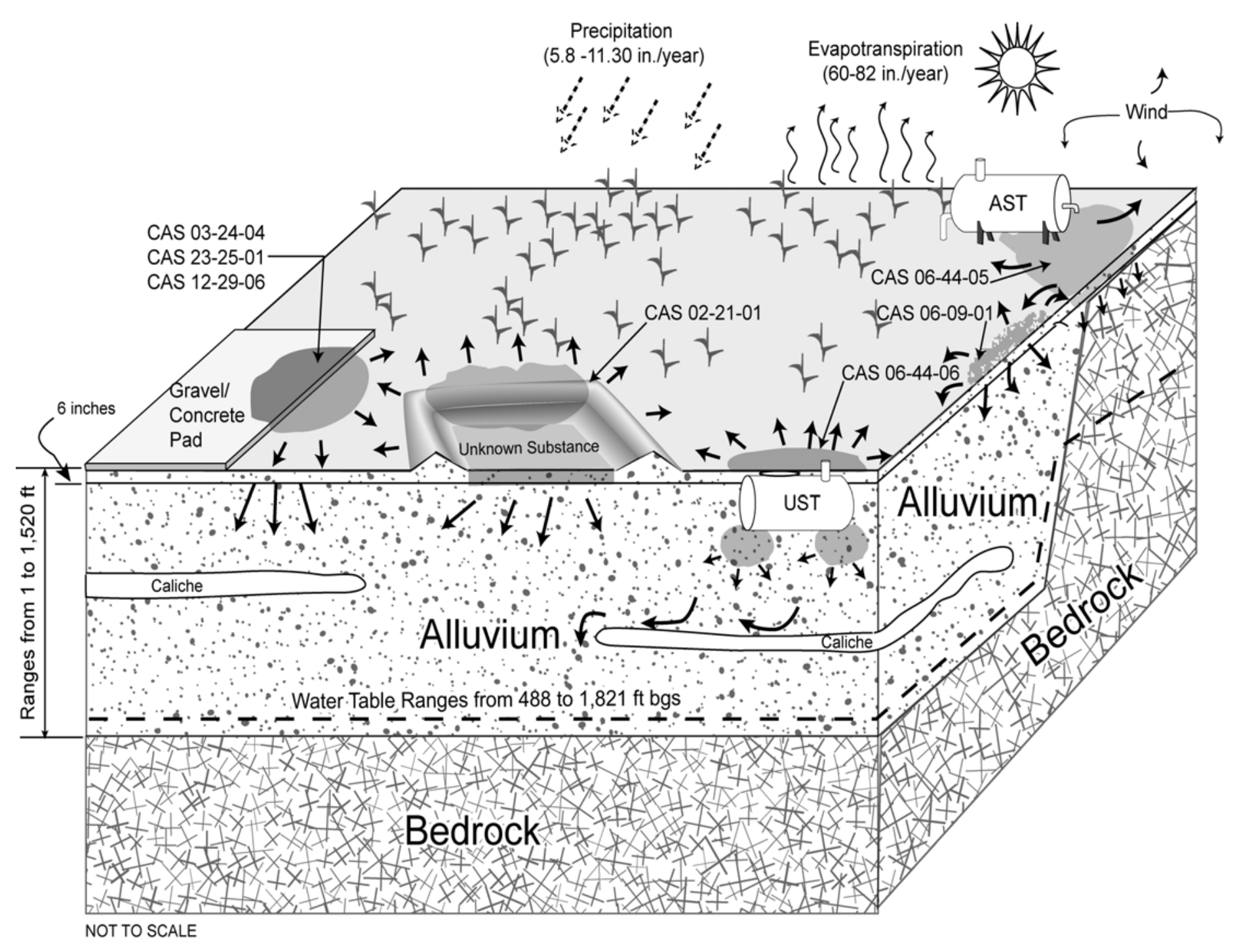

Figure 3-2

Conceptual Site Model for CAU 538 Corrective Action Sites 


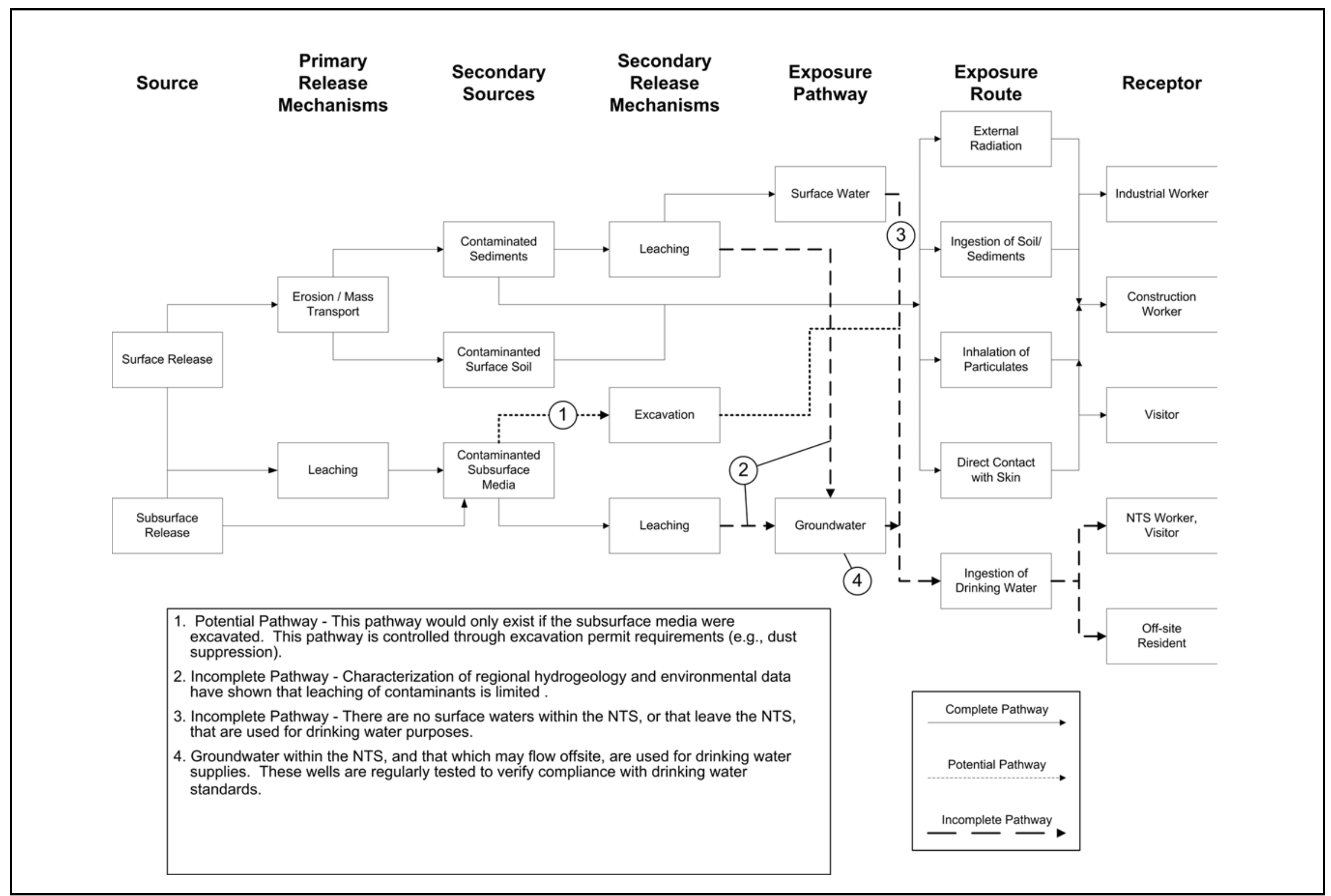

Figure 3-3

Conceptual Site Model Diagram for CAU 538 Corrective Action Sites

\section{Uncontrolled When Printed}




\subsection{Field Activities and Closure Objectives}

This section of the SAFER Plan provides a description of the field activities and closure objectives for CAU 538. The objectives for the field activities are to determine whether COCs exist. If remediation is determined to be feasible, then the extent of COCs will be determined so that a closure alternative may be implemented. All sampling activities will be conducted in compliance with the Industrial Sites QAPP (NNSA/NV, 2002b) and other applicable, approved procedures and instructions.

\subsection{Contaminants of Potential Concern}

The COPCs applicable to Decision I environmental samples from each of the CASs of CAU 538 are listed in Table 3-1 and are intended to encompass all of the contaminants that could potentially be present at each CAS. These contaminants were identified during the planning process through the review of site history, process knowledge, personal interviews, past investigation efforts (where available), and inferred activities associated with the CASs. Because complete information regarding activities performed at the CAU 538 sites is not available, contaminants detected at other similar or other NTS sites were included in the contaminant lists to reduce the uncertainty.

During the review of site historic documentation, process knowledge information, personal interviews, past investigation efforts (where available), and inferred activities associated with the CASs, some of the COPCs were identified as targeted analytes at specific CASs. Targeted analytes are those COPCs for which evidence in the available site and process information suggests that they may be reasonably suspected to be present at a given CAS. The targeted analytes are required to meet a more stringent completeness criteria than other COPCs, thus providing greater protection against a decision error (see Section 7.0). Targeted analytes identified for each CAU 538 CAS are also listed in Table 3-1.

\subsection{Remediation}

The DQOs for CAU 538 identified data gaps that require additional data collection before identifying and implementing the preferred closure alternative for each CAS. A decision point approach, based on the DQOs for making remediation decisions, is summarized in Figure 1-2. The presence of 
contamination, if any, is assumed to be confined to the spatial boundaries of the sites as defined in the CSM. Biased sampling will be conducted at CAU 538 according to DQO guidelines.

If COCs are identified within a CAS based on the initial investigation results, that CAS will be further assessed before implementing closure activities. If COPCs are not present at concentrations exceeding FALs, the CAS will be recommended for no further action.

The objective of the initial investigation strategy is to determine whether COCs are present. Laboratory analytical results will be used to confirm the presence or absence of COCs.

If COCs are present, or it is decided that COCs may be present based on the presence of biasing factors, and remediation action of removal for disposal may be implemented and additional verification samples taken from biased locations within the excavation.

The sampling strategy targets the locations and media that are most likely to be contaminated. Biasing factors will be used along with available process knowledge for choosing the sample locations for this investigation. The following biasing factors will be considered in selecting locations for analytical samples at CAU 538:

- Process knowledge of sources, and location of release (e.g., volume of release). Locations that may reasonably have been contaminated based on the results of previous field investigations.

- Stains: Any spot or area on the soil surface that may indicate the presence of a potentially hazardous liquid. Typically, stains indicate an organic liquid such as an oil has reached the soil, and may have spread out vertically and horizontally.

- Elevated Radiation: Any location identified during radiological surveys having alpha/beta/gamma levels significantly higher than surrounding background soil.

- Geophysical Anomalies: Any location identified during geophysical surveys that have results indicating subsurface materials existed, and were not consistent with the natural surroundings.

- Debris: Presence of materials of interest such as debris, waste, or equipment that may have been used at, or added to, a location, and may have come in contact with hazardous substances at some point during their use.

- Lithology: Locations where variations in lithology (soil or rock) indicate that different conditions or materials exist. 
- Site History: Locations for which evidence such as historical photographs, process knowledge, existing data, and experience from previous investigations, and/or interviewee's input exists that a release of hazardous or radioactive substances may have occurred.

- Additional Biasing Factors: Any other indication of potential contamination such textural discontinuities, disturbance of native soils, or odor.

Predetermined judgmental sample locations may be modified by the Site Supervisor, based on the culmination of all the biasing data generated throughout the investigation. Additional samples may be collected for waste management characterization and disposal purposes.

Field screening may be instituted to support selection of biased sample locations. These FSRs, along with other biasing factors, will help guide the selection(s) of the most appropriate sampling location for collection of laboratory samples. Potential field screening and field survey methods, with the applicable decision criteria, are presented below:

- Headspace Analysis: The field-screening levels (FSLs) for VOCs are $20 \mathrm{ppm}$ or 2.5 times background, whichever is greater. A photoionization detector (PID), or an equivalent instrument or method, will be used to conduct headspace analysis at all CASs because VOCs are a common concern at the NTS and have not been ruled out based on process knowledge.

- Gas Chromatography: The TPH FSRs greater than 75 ppm measure using a gas chromatograph, or equivalent equipment or method, may be used to field screen samples.

- Radiological Surveys: Alpha and beta/gamma radiation can be detected by using an NT Technology Electra, or equivalent instrument or method, to survey individual samples or areas. The FSLs for soil are established for each CAS as the mean background activity plus two times the standard deviation of the mean background activity.

- Walkover Surface Area Radiological Surveys: A plastic scintillator may be used over as much of the CAS boundaries as permitted by terrain and field conditions to detect hot spots of radiological contamination.

- Gamma Spectroscopy: The identification of gamma-emitting radionuclides may be conducted by gamma spectroscopy, or an equivalent instrument or method, on samples that show an elevated total alpha or beta/gamma FSR, and/or comply with transportation requirements.

Surveys may (e.g., geophysical) also be conducted to locate buried utility lines are known or supposed to be present. The primary intrusive investigation techniques that may be applied during 
the investigation are hand sampling (e.g., scoops), excavation using hand tools (e.g., shovels) or a backhoe, and drilling using a hand auger or drill rig.

The information necessary to satisfy the DQO data needs will be generated for each CAU 538 CAS by collecting and analyzing samples generated during a field investigation. The presence and nature of contamination at each CAS will be evaluated by collecting samples at biased locations that are determined to be most probable to contain COCs if they are present anywhere within the CAS. These locations will be determined based on their identification using the biasing factors listed in this section.

Decision I soil samples will be collected from selected locations based on the CSM and biasing factors. If biasing factors are present in soils below locations where Decision I samples were collected, additional and deeper Decision I soil samples will be collected to a depth where the biasing factors are no longer present.

If removal of COCs is not feasible, information on the extent of COC contamination will be obtained by collecting Decision II step-out samples. Decision II sampling will consist of further defining the extent of contamination where COCs have been confirmed. Step-out (Decision II) sampling locations at each CAS will be selected based on the CSM, biasing factors, FSRs, existing data, and the outer boundary sample locations where COCs were detected. In general, Decision II sample locations will be arranged in a triangular pattern around areas containing a $\mathrm{COC}$ at distances based on site conditions, $\mathrm{COC}$ concentrations, process knowledge, and other biasing factors. If $\mathrm{COCs}$ extend beyond the initial step-out locations, additional Decision II samples will be collected from locations further from the source. If a spatial boundary is reached, the CSM is shown to be inadequate, or the Site Supervisor determines that extent sampling needs to be re-evaluated, work will be temporarily suspended, NDEP will be notified, and the investigation strategy will be re-evaluated. If remediation is feasible, a minimum of one analytical result less than the action level from each lateral and vertical direction will be required to define the extent of $\mathrm{COC}$ contamination. The lateral and vertical extent of COCs will only be established based on validated laboratory analytical results (i.e., not field screening). 
Biasing factors (including FSRs) will be used to select the most appropriate samples from a particular location for submittal to the analytical laboratory. Biasing factors to be used for selection of sampling locations are listed in Section B.4.2.1 of Appendix B.

As biasing factors are identified and used for selection of sampling locations, they will be documented in the appropriate field documents. The CAS-specific sampling strategy and the estimated locations of biased samples for each CAS are presented in Appendix B.

The number, location, and spacing of step-outs may be modified as warranted by site conditions and the justification documented in the field logbook. The analytical methods and laboratory requirements (i.e., detection limits, precision) for the COPCs are provided in Tables 7-2 and 7-3. The COPCs and targeted analytes identified for each CAS are presented in Table 3-1. All sampling activities and quality control (QC) requirements for field and laboratory environmental sampling will be conducted in compliance with the Industrial Sites QAPP (NNSA/NV, 2002b) and other applicable, approved procedures.

Sample locations may be modified based on site conditions, obvious debris or staining of soils, FSRs, or professional judgment. The Task Manager or Site Supervisor has the discretion to modify the biased locations if the modified locations meet the DQO decision needs and criteria stipulated in Appendix B.

Because this SAFER Plan only addresses contamination originating from the CAU, it may be necessary to distinguish overlapping contamination originating from other sources. For example, widespread surface radiological contamination originating from atmospheric tests will not be addressed in the CAU 538 investigation. To determine whether contamination is from the CAU or from other sources, soil samples may be collected from background locations at selected CASs.

Modifications to the investigation strategy may be required should unexpected field conditions be encountered at any CAS. Significant modifications shall be justified and documented in a Record of Technical Change before implementation. If an unexpected condition indicates that conditions are significantly different than the corresponding CSM, the activity will be rescoped and the decision makers will be notified. Field activities at CAU 538 include site preparation, sample location 
selection, sample collection activities, waste characterization, photodocumentation, and collection of geo-coordinates.

\subsection{Verification}

The information necessary to satisfy the DQO data needs will be generated for each CAU 538 CAS by collecting and analyzing samples generated during a field investigation. The presence and nature of contamination at each CAS will be evaluated by collecting samples at biased locations that are determined to be most probable to contain COCs if they are present anywhere within the CAS. These locations will be determined based on their identification using the biasing factors listed in this section.

Decision I soil samples will be collected from selected locations based on the CSM and biasing factors. If biasing factors are present in soils below locations where Decision I samples were collected, additional and deeper Decision I soil samples will be collected to a depth where the biasing factors are no longer present.

If removal of COCs is not feasible, information on the extent of COC contamination will be obtained by collecting step-out (Decision II) samples. Decision II sampling will consist of further defining the extent of contamination where COCs have been confirmed. Step-out (Decision II) sampling locations at each CAS will be selected based on the CSM, biasing factors, FSRs, existing data, and the outer boundary sample locations where COCs were detected. In general, step-out sample locations will be arranged in a triangular pattern around areas containing a COC at distances based on site conditions, COC concentrations, process knowledge, and other biasing factors. If COCs extend beyond step-out locations, additional Decision II samples will be collected from locations further from the source. If a spatial boundary is reached, the CSM is shown to be inadequate, or the Site Supervisor determines that extent sampling needs to be re-evaluated, work will be temporarily suspended, NDEP will be notified, and the investigation strategy will be re-evaluated.

The number, location, and spacing of step-outs may be modified as warranted by site conditions and the justification documented in the field logbook. Section 7.2 provides the analytical methods and laboratory requirements (i.e., detection limits, precision, and accuracy requirements) to be used when analyzing the COPCs. The analytical program for each CAS is presented in Table 3-1. All sampling 
activities and QC requirements for field and laboratory environmental sampling will be conducted in compliance with the Industrial Sites QAPP (NNSA/NV, 2002b) and other applicable, approved procedures.

If removal of COCs is feasible, verification sampling of remaining environmental media will be required. The verification samples will be collected from the approximate center of the bottom of the excavation below the stained area and at lateral boundaries. The final locations and numbers of verification samples to be collected will be determined in the field based on the presence of any biasing factors as listed in Section B.4.2.1 of Appendix B, the size of the excavation, site conditions, and the professional judgment of the Site Supervisor. All verification sample locations must meet the DQO decision needs and criteria stipulated in Appendix B. The number and location of verification samples will be justified in the Closure Report.

Because this SAFER Plan only addresses contamination originating from the CAU, it may be necessary to distinguish overlapping contamination originating from other sources. For example, widespread surface radiological contamination originating from atmospheric tests will not be addressed in the CAU 538 investigation. To determine whether contamination is from the CAU or from other sources, soil samples may be collected from background locations at selected CASs.

Modifications to the investigation strategy may be required should unexpected field conditions be encountered at any CAS. Significant modifications shall be justified and documented in a Record of Technical Change before implementation. If an unexpected condition indicates that conditions are significantly different than the corresponding CSM, the activity will be rescoped and the decision makers will be notified. Field activities at CAU 538 include site preparation, sample location selection, sample collection activities, waste characterization, photodocumentation, and collection of geo-coordinates.

Each sample collected will be submitted for laboratory analysis for the COPCs identified in Table 3-1. If analytical results are above closure standards, additional soil excavation and verification sampling will be conducted until the closure criteria are met. If more than one round of excavation and verification sampling is required, COPCs may be eliminated from subsequent rounds based on validated analytical data and professional judgment of the Site Supervisor. Additional samples may 
be collected for waste management purposes. Table 4-1 summarizes the sampling approach for each of the CASs in CAU 538.

\subsubsection{Corrective Action Site 02-21-01, Epoxy Tar Pit}

The preparation activities to be completed before sampling activities begin at this CAS include conducting a radiological survey over the surface of the site to identify any areas of radioactivity exceeding local background levels. Areas with radiological survey results statistically above background may be sampled, field screened on site for gamma-emitting radionuclides (e.g., gamma spectroscopy analysis), and/or submitted for laboratory analysis based on the radiological survey and gamma spectroscopy results. A minimum of four samples will be collected from the unknown substance at two sample locations. Three excavations will be conducted through the fill material to the native soil interface. Samples may be field screened using methods described in Section 4.2.

Figure B.8-2 in Appendix B shows a plan view of the CAS showing the planned excavation and sample locations. The fill material in the pit will be examined during excavation activities for drilling mud physical characteristics (i.e., clay-like consistency) to determine whether the fill material contains drilling mud. In addition, if biasing factors are identified at this site during excavation activities, samples will be collected and analyzed. Sample locations will be selected where biasing factors such as drilling mud are identified, and samples will be collected and submitted for analysis in accordance with the analytical protocol listed in Table 3-1. Additional Decision I and/or Decision II sample locations may be identified during the field investigation based on the CSM and/or biasing factors listed in Section 4.2.

\subsubsection{Corrective Action Site 03-25-04, Hydrocarbon Stain}

Site preparation activities to be completed before sampling activities for this CAS include conducting a radiological survey over the entire surface of the site to identify any areas of elevated radioactivity exceeding local background levels. Areas with radiological survey results statistically above background may be sampled, field screened on site for gamma-emitting radionuclides (e.g., gamma spectroscopy analysis), and/or submitted for laboratory analysis based on the radiological survey and gamma spectroscopy results. A minimum of two samples will be collected from the surface of the 
stained soil and beneath the deepest stained soil at two sample locations. Samples may be field screened using the methods described in Section 4.2.

Figure B.8-4 in Appendix B shows a plan view of the CAS area and the planned sample locations. Additional Decision I and/or Decision II sample locations may be identified during the field investigation based on the CSM and/or biasing factors listed in Section 4.2.

\subsubsection{Corrective Action Site 06-09-01, Cement Washdown}

No pre-investigation activities are required at this site. No environmental concern was identified for this CAS. To confirm the lack of any biasing factors, a site walkover will be conducted. If biasing factors are identified, these locations will be sampled and analyzed.

Figure B.8-6 in Appendix B shows a plan view of the CAS area and transects spaced $20 \mathrm{ft}$ apart. The site walkover will be conducted along the marked transects looking for any biasing factors indicating a potential environmental concern. Any identified environmental concern will be designated as a sample location. Samples will be collected from designated sample locations, field screened as appropriate, and submitted for laboratory analysis.

\subsubsection{Corrective Action Site 06-44-05, Diesel Spill From Tank \#38061}

Pre-investigation activities to be completed before sampling activities for this CAS include conducting a radiological survey over the surface of the site to identify any areas of elevated radiation exceeding local background levels. Areas with radiological survey results statistically above background may be sampled, field screened on site for gamma-emitting radionuclides (e.g., gamma spectroscopy analysis), and/or submitted for laboratory analysis based on the radiological survey and gamma spectroscopy results. Surface and subsurface samples will be collected from a minimum of three sample locations for laboratory analyses. Samples may be field screened using methods described in Section 4.2.

Figure B.8-8 in Appendix B shows a plan view of the CAS area and the planned sample locations. Additional Decision I and/or Decision II sample locations may be identified during the field investigation based on the CSM and/or biasing factors listed in Section 4.2. 


\subsubsection{Corrective Action Site 06-44-06, Spill Site with Hydrocarbons}

Pre-investigation activities to be completed before sampling activities for this CAS include conducting a radiological survey over the surface of the site to identify any areas of elevated radiation exceeding local background levels. Areas with radiological survey results statistically above background may be sampled, field screened for gamma-emitting radionuclides (e.g., gamma spectroscopy analysis), and/or submitted for laboratory analysis based on the radiological survey and gamma spectroscopy results. A minimum of 14 samples will be collected from the surface and shallow subsurface soil from seven sample locations planned $60 \mathrm{ft}$ north of the excavated UST. A minimum of four samples will be collected from two planned sample locations in the petroleum hydrocarbon-impacted subsurface soil within the use-restricted area. Samples may be field screened using methods described in Section 4.2.

Figure B.8-10 in Appendix B shows a plan view of the CAS area and the planned sample locations. Additional Decision I and/or Decision II sample locations may be identified during the field investigation based on the CSM and/or biasing factors listed in Section 4.2.

\subsubsection{Corrective Action Site 12-29-06, Spill Site}

Pre-investigation activities to be completed before sampling activities for this CAS include conducting a radiological survey over the surface of the site to identify areas of elevated radiation exceeding local background levels. Areas with radiological survey results statistically above background may be sampled, field screened for gamma-emitting radionuclides (e.g., gamma spectroscopy analysis), and/or submitted for laboratory analysis based on the radiological survey and gamma spectroscopy results. A minimum of 11 samples will be collected from 11 sample locations. Samples collected will include the surface and shallow subsurface soil surrounding the perimeter of the concrete building foundation, surface and shallow subsurface stained soil located northeast of the foundation, floor covering material on the section of the building foundation, the oily residue on the old oil transformer, and the asphalt outside the CAS to establish background levels for the hazardous constituents in the asphalt pavement covering the ground surface inside the CAS. Samples may be field screened using methods described in Section 4.2. 
Figure B.8-12 in Appendix B shows a plan view of the CAS area and the planned sample locations based. Additional Decision I and/or Decision II sample locations may be identified during the field investigation based on the CSM and/or biasing factors listed in Section 4.2.

\subsubsection{Corrective Action Site 23-25-01, Oil Stains}

Pre-investigation activities to be completed before sampling activities for this CAS include: (1) conducting a radiological survey over the surface of the site to identify areas of elevated radioactivity above local background levels, and (2) removing vegetation at select areas for sampling access. Areas with radiological survey results statistically above background may be sampled, field screened for gamma-emitting radionuclides (e.g., gamma spectroscopy analysis), and/or submitted for laboratory analysis based on the radiological survey and gamma spectroscopy results. A minimum of 11 samples will be collected from 11 planned sample locations. Sampled media will include the soil surrounding the perimeter of the concrete building foundation, the stained soil north of the foundation and east of the AST saddle, soil between the north AST saddle in proximity to the previous sample location, and asphalt outside the CAS to establish background levels for the hazardous constituents in the asphalt pavement covering the ground surface inside the CAS. Samples may be field screened using methods described in Section 4.2.

Figure B.8-14 in Appendix B shows a plan view of the CAS area and the planned sample locations. Additional Decision I and/or Decision II sample locations may be identified during the field investigation based on the CSM and/or biasing factors listed in Section 4.2.

The two floor drains in the concrete building foundation will be inspected as a best management practice to confirm that they have been plugged. Any breaches identified in the piping will not be addressed in this CAI. The video survey results will be documented (i.e., Field Activity Daily Log, Daily Field Activity Report).

Table 4-1 summarizes the sampling approach for each of the CASs in CAU 538 described in the above subsections. 
Table 4-1

Sampling Approach for CAU 538 Corrective Action Sites

(Page 1 of 3 )

\begin{tabular}{|c|c|c|c|c|c|c|c|}
\hline $\begin{array}{l}\text { Corrective } \\
\text { Action } \\
\text { Site }\end{array}$ & $\begin{array}{c}\text { Total } \\
\text { Number of } \\
\text { Samples }\end{array}$ & $\begin{array}{l}\text { Sample } \\
\text { Location }\end{array}$ & $\begin{array}{l}\text { Minimum } \\
\text { Number } \\
\text { of Sample } \\
\text { Locations }\end{array}$ & $\begin{array}{l}\text { Minimum } \\
\text { Number of } \\
\text { Samples } \\
\text { per } \\
\text { Location }\end{array}$ & $\begin{array}{l}\text { Sample Collection } \\
\text { Requirements }{ }^{1,2}\end{array}$ & $\begin{array}{l}\text { Samples Submitted } \\
\text { for Analysis }{ }^{3}\end{array}$ & $\begin{array}{l}\text { Sampling Method } \\
\text { Alternatives }\end{array}$ \\
\hline \multirow[b]{2}{*}{ 02-21-01 } & 4 & $\begin{array}{l}\text { Unknown } \\
\text { substance }\end{array}$ & 2 & 2 & $\begin{array}{l}\text { Representative sample of } \\
\text { unknown substance }\end{array}$ & $\begin{array}{l}\text { Surface sample and above } \\
\text { native soil interface }\end{array}$ & \multirow[b]{2}{*}{$\begin{array}{l}\text { Hand sampling } \\
\text { Backhoe excavation }\end{array}$} \\
\hline & $\mathrm{TBD}^{\mathrm{a}}$ & $\begin{array}{l}\text { Fill } \\
\text { material/biasing } \\
\text { factors in } \\
\text { excavations }\end{array}$ & $\mathrm{TBD}^{\mathrm{a}}$ & 1 & Observed biasing factors & $\begin{array}{l}\text { Sample collected from fill } \\
\text { material/native soil }\end{array}$ & \\
\hline $03-25-04$ & 4 & $\begin{array}{l}\text { Surface soil and } \\
\text { soil from beneath } \\
\text { the heaviest } \\
\text { stained soil }\end{array}$ & 2 & 2 & $\begin{array}{l}\text { Surface and shallow } \\
\text { subsurface samples. } \\
\text { If FSRs > FSLs, continue } \\
\text { collecting samples until } \\
\text { FSRs < FSLs in two } \\
\text { consecutive samples. }\end{array}$ & $\begin{array}{l}\text { Submit surface and shallow } \\
\text { subsurface samples. If the } \\
\text { FSRs > FSLs, then submit } \\
\text { the surface sample, the } \\
\text { sample with the highest } \\
\text { FSR > FSL, and the } \\
\text { shallowest sample with } \\
\text { FSRs < FSLs. }\end{array}$ & $\begin{array}{l}\text { Hand sampling } \\
\text { Backhoe excavation } \\
\text { Drill rig }\end{array}$ \\
\hline $06-09-01$ & TBD & TBD & TBD & TBD & TBD & TBD & TBD \\
\hline 06-44-05 & 3 & $\begin{array}{l}\text { Surface soil } \\
\text { interface }\end{array}$ & 3 & 1 & $\begin{array}{l}\text { Surface sample. If FSRs }> \\
\text { FSLs, continue collecting } \\
\text { samples until FSRs < FSLs } \\
\text { in two consecutive } \\
\text { samples. }\end{array}$ & $\begin{array}{l}\text { Submit surface sample. If } \\
\text { the FSRs > FSLs, then } \\
\text { submit the surface sample, } \\
\text { the sample with the highest } \\
\text { FSR > FSL, and the } \\
\text { shallowest sample with } \\
\text { FSRs < FSLs. }\end{array}$ & $\begin{array}{l}\text { Hand sampling } \\
\text { Backhoe excavation } \\
\text { Drill rig }\end{array}$ \\
\hline $06-44-06$ & 15 & $\begin{array}{l}\text { Surface or } \\
\text { subsurface soil } \\
60 \mathrm{ft} \text { north of } \\
\text { excavated UST }\end{array}$ & 15 & 1 & $\begin{array}{l}\text { Surface or shallow } \\
\text { subsurface sample. If } \\
\text { FSRs > FSLs, continue } \\
\text { collecting samples until } \\
\text { FSRs < FSLs in two } \\
\text { consecutive samples. }\end{array}$ & $\begin{array}{l}\text { Submit surface or shallow } \\
\text { subsurface sample. If the } \\
\text { FSRs > FSLs, then submit } \\
\text { the surface sample, the } \\
\text { sample with the highest } \\
\text { FSR > FSL, and the } \\
\text { shallowest sample with } \\
\text { FSRs < FSLs. }\end{array}$ & $\begin{array}{l}\text { Hand sampling } \\
\text { Hand augering } \\
\text { Backhoe excavation } \\
\text { Drill rig }\end{array}$ \\
\hline
\end{tabular}


Table 4-1

Sampling Approach for CAU 538 Corrective Action Sites

(Page 2 of 3 )

\begin{tabular}{|c|c|c|c|c|c|c|c|}
\hline $\begin{array}{l}\text { Corrective } \\
\text { Action } \\
\text { Site }\end{array}$ & $\begin{array}{c}\text { Total } \\
\text { Number of } \\
\text { Samples }\end{array}$ & $\begin{array}{l}\text { Sample } \\
\text { Location }\end{array}$ & $\begin{array}{l}\text { Minimum } \\
\text { Number } \\
\text { of Sample } \\
\text { Locations }\end{array}$ & $\begin{array}{l}\text { Minimum } \\
\text { Number of } \\
\text { Samples } \\
\text { per } \\
\text { Location }\end{array}$ & $\begin{array}{l}\text { Sample Collection } \\
\text { Requirements }\end{array}$ & $\begin{array}{l}\text { Samples Submitted } \\
\text { for Analysis }\end{array}$ & $\begin{array}{l}\text { Sampling Method } \\
\text { Alternatives }\end{array}$ \\
\hline $\begin{array}{l}\text { 6-44-06 } \\
\text { cont. }\end{array}$ & 15 & $\begin{array}{l}\text { Use restricted } \\
\text { subsurface soil } \\
\text { northeast of the } \\
\text { excavated UST }\end{array}$ & 2 & 1 & $\begin{array}{l}\text { Subsurface adjacent to } \\
\text { location with TPH } \\
\text { concentrations exceeding } \\
75 \text { ppm. If FSRs > FSLs, } \\
\text { continue collecting samples } \\
\text { until FSRs < FSLs in two } \\
\text { consecutive samples. }\end{array}$ & $\begin{array}{l}\text { Subsurface sample. If the } \\
\text { FSRs > FSLs, then submit } \\
\text { the surface sample, the } \\
\text { sample with the highest } \\
\text { FSR > FSL, and the } \\
\text { shallowest sample with } \\
\text { FSRs < FSLs. }\end{array}$ & $\begin{array}{l}\text { Hand sampling } \\
\text { Drill rig }\end{array}$ \\
\hline \multirow{5}{*}{$12-29-06$} & \multirow{5}{*}{11} & $\begin{array}{l}\text { Surface and } \\
\text { shallow } \\
\text { subsurface soil } \\
\text { surrounding the } \\
\text { perimeter of the } \\
\text { concrete building } \\
\text { foundation }\end{array}$ & 6 & 1 & $\begin{array}{l}\text { Surface or shallow } \\
\text { subsurface sample. If } \\
\text { FSRs > FSLs, continue } \\
\text { collecting samples until } \\
\text { FSRs < FSLs in two } \\
\text { consecutive samples. }\end{array}$ & \multirow{2}{*}{$\begin{array}{l}\text { Submit surface or shallow } \\
\text { subsurface sample. If the } \\
\text { FSRs > FSLs, then submit } \\
\text { the surface sample, the } \\
\text { sample with the highest } \\
\text { FSR > FSL, and the } \\
\text { shallowest sample with } \\
\text { FSRs < FSLs. }\end{array}$} & $\begin{array}{l}\text { Hand sampling } \\
\text { Hand augering } \\
\text { Backhoe excavation }\end{array}$ \\
\hline & & Stained soil & 1 & 1 & $\begin{array}{l}\text { Surface or shallow } \\
\text { subsurface sample. If } \\
\text { FSRs > FSLs, continue } \\
\text { collecting samples until } \\
\text { FSRs < FSLs in two } \\
\text { consecutive samples. }\end{array}$ & & $\begin{array}{l}\text { Hand sampling } \\
\text { Hand augering } \\
\text { Backhoe excavation } \\
\text { Drill Rig }\end{array}$ \\
\hline & & Floor covering & 1 & 1 & $\begin{array}{l}\text { Surface sample of floor } \\
\text { covering }\end{array}$ & $\begin{array}{l}\text { Submit sample of floor } \\
\text { covering }\end{array}$ & Hand scabbling \\
\hline & & $\begin{array}{l}\text { Oily residue on } \\
\text { old oil } \\
\text { transformer }\end{array}$ & 1 & 1 & $\begin{array}{l}\text { Swipe surface area with } \\
\text { residue }\end{array}$ & Submit swipe sample & Swipe sampling \\
\hline & & $\begin{array}{l}\text { Background } \\
\text { samples }\end{array}$ & 2 & 1 & $\begin{array}{l}\text { Surface sample of asphalt } \\
\text { located outside of CAS } \\
\text { footprint }\end{array}$ & Submit sample of asphalt & $\begin{array}{l}\text { Hand sampling } \\
\text { Backhoe excavation }\end{array}$ \\
\hline
\end{tabular}


Table 4-1

Sampling Approach for CAU 538 Corrective Action Sites

(Page 3 of 3 )

\begin{tabular}{|c|c|c|c|c|c|c|c|}
\hline $\begin{array}{l}\text { Corrective } \\
\text { Action } \\
\text { Site }\end{array}$ & $\begin{array}{l}\text { Total } \\
\text { Number of } \\
\text { Samples }\end{array}$ & $\begin{array}{l}\text { Sample } \\
\text { Location }\end{array}$ & $\begin{array}{l}\text { Minimum } \\
\text { Number } \\
\text { of Sample } \\
\text { Locations }\end{array}$ & $\begin{array}{l}\text { Minimum } \\
\text { Number of } \\
\text { Samples } \\
\text { per } \\
\text { Location }\end{array}$ & $\begin{array}{l}\text { Sample Collection } \\
\text { Requirements }^{1,2}\end{array}$ & $\begin{array}{l}\text { Samples Submitted } \\
\text { for Analysis }{ }^{3}\end{array}$ & $\begin{array}{l}\text { Sampling Method } \\
\text { Alternatives }\end{array}$ \\
\hline \multirow{4}{*}{ 23-25-01 } & \multirow{4}{*}{11} & $\begin{array}{l}\text { Soil surrounding } \\
\text { the perimeter of } \\
\text { the concrete } \\
\text { building } \\
\text { foundation }\end{array}$ & 6 & 1 & $\begin{array}{l}\text { Surface or shallow } \\
\text { subsurface sample. If } \\
\text { FSRs > FSLs, continue } \\
\text { collecting samples until } \\
\text { FSRs < FSLs in two } \\
\text { consecutive samples }\end{array}$ & \multirow{3}{*}{$\begin{array}{l}\text { Submit surface or shallow } \\
\text { subsurface sample. If the } \\
\text { FSRs > FSLs, then submit } \\
\text { the surface sample, the } \\
\text { sample with the highest } \\
\text { FSR > FSL, and the } \\
\text { shallowest sample with } \\
\text { FSRs < FSLs. }\end{array}$} & \multirow{3}{*}{$\begin{array}{l}\text { Hand sampling, } \\
\text { Backhoe excavation } \\
\text { Drill rig } \\
\text { Hand augering }\end{array}$} \\
\hline & & Stained soil & 1 & 1 & $\begin{array}{l}\text { Surface or shallow } \\
\text { subsurface sample. If } \\
\text { FSRs > FSLs, continue } \\
\text { collecting samples until } \\
\text { FSRs < FSLs in two } \\
\text { consecutive samples. }\end{array}$ & & \\
\hline & & $\begin{array}{l}\text { Soil sample } \\
\text { between AST } \\
\text { saddles (one at } \\
\text { previous sample } \\
\text { location) }\end{array}$ & 2 & 1 & $\begin{array}{l}\text { Surface or shallow } \\
\text { subsurface sample. If } \\
\text { FSRs > FSLs, continue } \\
\text { collecting samples until } \\
\text { FSRs < FSLs in two } \\
\text { consecutive samples. }\end{array}$ & & \\
\hline & & $\begin{array}{l}\text { Surface sample } \\
\text { of asphalt } \\
\text { located outside } \\
\text { of CAS footprint }\end{array}$ & 2 & 1 & $\begin{array}{l}\text { Surface sample collected } \\
\text { from disturbed location } \\
\text { outside of CAS footprint }\end{array}$ & $\begin{array}{l}\text { Submit surface sample of } \\
\text { asphalt }\end{array}$ & Hand sampling \\
\hline
\end{tabular}

aSamples will only be collected at locations where biasing factors are observed during excavation activities.

${ }^{1}$ For worker protection, field screening will not be conducted if a strong odor and/or visual evidence suggests contamination is present.

${ }^{2}$ Additional samples may be collected at the discretion of the Site Supervisor.

${ }^{3}$ Additional samples may be submitted at the discretion of the Site Supervisor.

${ }^{4}$ Surface sample interval is 0 to 6 inches. Shallow subsurface sample interval is 6 inches to $5 \mathrm{ft}$. Subsurface sample interval is greater than $5 \mathrm{ft}$.
AST = Aboveground storage tank
$\mathrm{FSL}=$ Field-screening level
TBD $=$ To be determined
UST $=$ Underground storage tank 


\subsection{Closure}

The following activities, at a minimum, have been identified for closure of these CASs. The decision logic behind the activities is provided in Figure 1-2:

- If no COCs are detected, the CAS will be closed with no further action.

- If COCs are present and removal is not feasible, closure in place will be the preferred corrective action alternative. The appropriate use restrictions will be implemented and documented in the SAFER CR.

- If COCs are present and removal is feasible, clean closure will be the preferred corrective action alternative. The material to be remediated will be removed and disposed as waste, and verification samples will be collected in remaining soil. Verification analytical results will be documented in the SAFER CR.

\subsection{Duration}

Table 4-2 gives a tentative duration of activities (in work days) for SAFER activities:

Table 4-2

Tentative Duration of Activities for SAFER Activities

\begin{tabular}{|c|l|}
\hline $\begin{array}{c}\text { Duration } \\
\text { (days) }\end{array}$ & \multicolumn{1}{c|}{ Activity } \\
\hline \hline 18 & Site Preparation \\
\hline 2 & Site Mobilization \\
\hline 22 & Field Work \\
\hline 2 & Site Demobilization \\
\hline 22 & Sample Analysis \\
\hline 42 & Data Validation and Assessment \\
\hline 195 & Closure Report \\
\hline 180 & Waste Management and Disposition \\
\hline
\end{tabular}




\subsection{Reports and Records Availability}

During field activities, a daily report will be prepared summarizing all field activities conducted that day. The report will include the project accomplishments, problems encountered and resolutions, and personnel and equipment utilized. The report will be submitted to the NNSA/NSO Environmental Restoration Project Federal Industrial Sites Sub-Project Task Manager.

Upon completion of the field activities, a CR will be prepared to include the following:

- Introduction (Purpose and Scope)

- Data Quality Assessment

- Closure Activities (Description of Field Activities)

- Waste Disposition

- Conclusions

Historic information and documents referenced in this plan are retained in the NNSA/NSO project files in Las Vegas, Nevada, and can be obtained through written request to the NNSA/NSO Environmental Restoration Project Federal Industrial Sites Sub-Project Director. This document is available in the DOE public reading rooms located in Las Vegas and Carson City, Nevada, or by contacting the appropriate DOE project manager. The NDEP maintains the official Administrative Record for all activities conducted under the auspices of the FFACO. 


\subsection{Investigation/Remediation Waste Management}

Management of IDW and remediation waste will be based on regulatory requirements, field observations, process knowledge, and laboratory results from CAU 538 investigation samples.

Disposable sampling equipment, PPE, and rinsate are considered potentially contaminated waste only by virtue of contact with potentially contaminated media (e.g., soil) or potentially contaminated debris (e.g., construction materials). Therefore, sampling and analysis of IDW, separate from analyses of site investigation samples, may not be necessary for all IDW. However, if associated investigation samples are found to contain contaminants above regulatory levels, conservative estimates of total waste contaminant concentrations may be made based on the mass of the waste, the amount of contaminated media contained in the waste, and the maximum concentration of contamination found in the media. Direct samples of IDW may also be taken to support waste characterization.

Sanitary, hazardous, radioactive, and/or mixed waste (i.e., IDW and remediation waste), if generated, will be managed and disposed of in accordance with DOE Orders, U.S. Department of Transportation (DOT) regulations, state and federal waste regulations, and agreements and permits between DOE and NDEP.

\subsection{Waste Minimization}

Investigation activities are planned to minimize waste (i.e., IDW and remediation waste) generation. This will be accomplished by incorporating the use of process knowledge, visual examination, and/or radiological survey and swipe results. When possible, disturbed media (such as soil removed during trenching) or debris will be returned to its original location. Contained media (e.g., soil managed as waste) as well as other waste will be segregated to the greatest extent possible to minimize generation of hazardous, radioactive, or mixed waste. Hazardous material used at the sites will be controlled in order to limit unnecessary generation of hazardous or mixed waste. Administrative controls, including decontamination procedures and waste characterization strategies, will minimize waste generated and screened for radiation during investigations. 


\subsection{Potential Waste Streams}

The on-site management and ultimate disposition of waste (i.e., IDW, field-screening waste, and/or remediation waste) will be determined based on a determination of the waste type (e.g., sanitary, low-level, hazardous, hydrocarbon, or mixed), or the combination of waste types. A determination of the waste type will be guided by several factors, including, but not limited to: the analytical results of samples either directly or indirectly associated with the waste, historical site knowledge, knowledge of the waste generation process, field observations, field-monitoring/screening results, and/or radiological survey/swipe results. Office trash and lunch waste will be sent to the sanitary landfill by placing the waste in a dumpster. Each waste stream generated will be reviewed and segregated to the greatest extent at the point of generation.

Table 4-2 of the NV/YMP RadCon Manual (NNSA/NSO, 2005b) shall be used to determine whether such materials may be declared nonradioactive. On-site IDW management requirements by waste type are detailed in the following sections. Applicable waste management regulations and requirements are listed in Table 6-1.

\subsubsection{Sanitary Waste}

Sanitary IDW generated at each CAS will be collected, managed, and disposed of in accordance with the sanitary waste management regulations and the permits for operation of the NTS 10c Industrial Waste Landfill.

\subsubsection{Low-Level Radioactive Waste}

Radiological swipe surveys and/or direct-scan surveys may be conducted on reusable sampling equipment and the PPE and disposable sampling equipment waste streams exiting the work site. This allows for the immediate segregation of radioactive waste from waste that may be unrestricted regarding radiological release. Removable contamination limits, as defined in Table 4-2 of the current version of the NV/YMP RadCon Manual (NNSA/NSO, 2005b), will be used to determine whether such waste may be declared unrestricted regarding radiological release versus being declared radioactive waste. Direct sampling of the waste (i.e., IDW and/or remediation waste) may be conducted to aid in determining whether a particular waste unit (e.g., drum of soil) contains low-level 
Table 6-1

Waste Management Regulations and Requirements

\begin{tabular}{|c|c|c|}
\hline Waste Type & Federal Regulation & Additional Requirements \\
\hline Solid (nonhazardous) & $\mathrm{N} / \mathrm{A}$ & $\begin{array}{c}\text { NRS }^{a} 444.440-444.620 \\
\text { NAC }^{b} 444.570-444.7499 \\
\text { NTS Landfill Permit SW13.097.04 } \\
\text { NTS Landfill Permit SW13.097.03 }\end{array}$ \\
\hline Liquid/Rinsate (nonhazardous) & $\mathrm{N} / \mathrm{A}$ & $\begin{array}{l}\text { Water Pollution Control General Permit } \\
\text { GNEV93001, Rev. 3iii }\end{array}$ \\
\hline Hazardous & $\begin{array}{c}\text { RCRA }^{f}, \\
40 \text { CFR 260-282 }\end{array}$ & $\begin{array}{c}\text { NRS }^{\mathrm{a}} 459.400-459.600 \\
\mathrm{NAC}^{\mathrm{b}} 444.850-444.8746 \\
\mathrm{POC}^{\mathrm{g}}\end{array}$ \\
\hline Low-Level Radioactive & $\mathrm{N} / \mathrm{A}$ & DOE Orders and NTSWAC ${ }^{h}$ \\
\hline Mixed & $\begin{array}{c}\text { RCRA }^{f}, \\
40 \text { CFR } 260-282\end{array}$ & $\begin{array}{l}\text { NTSWAC }^{\mathrm{h}} \\
\text { POC }^{\mathrm{g}}\end{array}$ \\
\hline Hydrocarbon & $\mathrm{N} / \mathrm{A}$ & NTS Landfill Permit SW13.097.02 \\
\hline Polychlorinated Biphenyls & $\begin{array}{l}\text { TSCA }^{\mathrm{j}} \\
40 \text { CFR } 761\end{array}$ & $\begin{array}{l}\text { NRS }^{a} 459.400-459.600 \\
\text { NAC }^{b} 444.940-444.9555\end{array}$ \\
\hline Asbestos & $\begin{array}{c}\text { TSCA }^{\mathrm{j}} \\
40 \text { CFR } 763\end{array}$ & $\begin{array}{l}N_{R S}{ }^{a} 618.750-618.850 \\
\text { NAC }^{\text {b }} 444.965-444.976\end{array}$ \\
\hline
\end{tabular}

${ }^{a}$ Nevada Revised Statutes (NRS, 2005a, b, c)

${ }^{\mathrm{b}}$ Nevada Administrative Code (NAC, 2004a, b, c, d)

${ }^{\mathrm{c}}$ Area 23 Class II Solid Waste Disposal Site (NDEP, 1997a)

${ }^{\mathrm{d} A r e a} 9$ Class III Solid Waste Disposal Site (NDEP, 1997c)

eNevada Test Site Sewage Lagoons (NDEP, 1999)

${ }^{\mathrm{f}}$ Resource Conservation and Recovery Act (CFR, 2005a, b, c)

${ }^{9}$ Nevada Test Site Performance Objective for the Certification of Nonradioactive Hazardous Waste (BN, 1995)

${ }^{h}$ Nevada Test Site Waste Acceptance Criteria, Revision 6 (NNSA/NSO, 2005a)

'Area 6 Class III Solid Waste Disposal Site for Hydrocarbon Waste (NDEP, 1997b)

${ }^{\mathrm{j}}$ Toxic Substances Control Act (CFR, 2005d, e)

CFR $=$ Code of Federal Regulations

DOE $=$ U.S. Department of Energy

$\mathrm{N} / \mathrm{A}=$ Not applicable

NAC $=$ Nevada Administrative Code

NDEP $=$ Nevada Division of Environmental Protection

NRS $=$ Nevada Revised Statutes

NTS $=$ Nevada Test Site

NTSWAC $=$ Nevada Test Site Waste Acceptance Criteria

$\mathrm{POC}=$ Performance Objective for the Certification of Nonradioactive Hazardous Waste

$\mathrm{RCRA}=$ Resource Conservation and Recovery Act

TSCA = Toxic Substance Control Act 
radioactive waste, as necessary. Waste that is determined to be below the values of Table 4-2, by either direct radiological survey/swipe results or through process knowledge, will not be managed as potential radioactive waste but will be managed in accordance with the appropriate section of this document. Wastes in excess of Table 4-2 values will be managed as potential radioactive waste and be managed in accordance with this section and any other applicable sections of this document.

Low-level radioactive waste, if generated, will be managed in accordance with the contractor-specific waste certification program plan, DOE orders, and the requirements of the current version of the Nevada Test Site Waste Acceptance Criteria (NTSWAC) (NNSA/NSO, 2005a). Potential radioactive waste drums containing soil, PPE, disposable sampling equipment, and/or rinsate may be staged at a designated radioactive materials area (RMA) or radiologically controlled area when full or at the end of an investigation phase. The waste drums will remain at the RMA pending certification and disposal under NTSWAC requirements (NNSA/NSO, 2005a).

\subsubsection{Hazardous Waste}

Suspected hazardous wastes (i.e., IDW and/or remediation waste) will be placed in DOT-compliant containers. All containerized hazardous waste will be handled, inspected, and managed in accordance with 40 CFR 265, Subpart I (CFR, 2005a). These provisions include managing the waste in containers compatible with the waste type, and segregating incompatible waste types so that in the event of a spill, leak, or release, incompatible wastes shall not contact one another. Corrective Action Unit 538 will have waste storage areas established according to the needs of the project. Satellite accumulation areas and hazardous waste accumulation areas will be managed consistent with the requirements of Federal and State regulations (CFR, 2005a; NAC, 2004b). They will be properly controlled for access and equipped with spill kits and appropriate spill containment.

Hazardous waste accumulation areas will be covered under a site-specific emergency response and contingency action plan until such time that the waste is determined to be nonhazardous or all containers of hazardous waste have been removed from the storage area. Hazardous wastes will be characterized in accordance with the requirements of Title 40 CFR 261 (CFR, 2005a). No RCRA "listed" wastes have been identified at CAU 538. Any waste determined to be hazardous will be transported in accordance with RCRA and DOT to a permitted treatment, storage, and disposal facility (CFR, 2005a). 


\subsubsection{Hydrocarbon Waste}

Hydrocarbon waste (i.e., IDW and/or remediation waste) containing more than $100 \mathrm{mg} / \mathrm{kg}$ of TPH will be managed on site in a drum or other appropriate container until fully characterized. Hydrocarbon waste may be disposed of at a designated hydrocarbon landfill (NDEP, 1997b), an appropriate hydrocarbon waste management facility (e.g., recycling facility), or other method in accordance with Nevada regulations.

\subsubsection{Mixed Low-Level Waste}

Mixed waste (i.e., IDW and/or remediation waste), if generated, shall be managed and dispositioned according to the requirements of RCRA (CFR, 2005a) or subject to agreements between NNSA/NSO and the State of Nevada, as well as DOE requirements for radioactive waste. The waste will be marked with the words "Hazardous Waste Pending Analysis" and "Radioactive Waste Pending Analysis." Waste characterized as mixed will not be stored for a period of time that exceeds the requirements of RCRA unless subject to agreements between NNSA/NSO and the State of Nevada. The mixed waste shall be transported via an approved hazardous waste/radioactive waste transporter to the NTS transuranic waste storage pad for storage pending treatment or disposal. Waste with hazardous waste constituent concentrations below Land Disposal Restrictions may be disposed of at the NTS Area 5 Radioactive Waste Management Site if the waste meets the requirements of the NTSWAC (NNSA/NSO, 2005a). Waste with hazardous waste constituent concentrations exceeding Land Disposal Restrictions will require development of a treatment and disposal plan under the requirements of the Mutual Consent Agreement between DOE and the State of Nevada (NDEP, 1995).

\subsubsection{Polychlorinated Biphenyls}

The management of PCBs is governed by the Toxic Substances Control Act (TSCA) (USC, 1976) and its implementing regulations at 40 CFR 761 (CFR, 2005b). Polychlorinated biphenyls contamination may be found as a sole contaminant or in combination with any of the types of waste (i.e., IDW and/or remediation waste) discussed in this document. For example, PCBs may be a co-contaminant in soil that contains a RCRA "characteristic" waste (PCB/hazardous waste), or in soil that contains radioactive wastes $(\mathrm{PCB} /$ radioactive waste), or even in mixed waste $(\mathrm{PCB} /$ radioactive/hazardous 
waste). The IDW will initially be evaluated using analytical results for media samples from the investigation. If any type of PCB waste is generated, it will be managed according to 40 CFR 761 (CFR, 2005b) as well as State of Nevada requirements, (NAC, 2004c) guidance, and agreements with NNSA/NSO.

\subsection{Management of Specific Waste Streams}

\subsubsection{Personal Protective Equipment}

Personal protective equipment and disposable sampling equipment will be visually inspected for stains, discoloration, and gross contamination as the waste is generated. Any IDW that meets this description will be segregated and managed as potentially "characteristic" hazardous waste. This segregated population of waste will either be (1) assigned the characterization of the soil/sludge that was sampled, (2) sampled directly, or (3) undergo further evaluation using the soil/sludge sample results to determine how much soil/sludge would need to be present in the waste to exceed regulatory levels. The PPE and equipment that is not visibly stained, discolored, or grossly contaminated and that is within radiological free-release criteria will be managed as nonhazardous sanitary waste.

\subsubsection{Management of Soil}

Soil may be removed for disposal during soil sampling, excavation, drilling, and/or as an interim corrective action, and characterized based on laboratory analytical results from representative locations. If the waste soil (i.e., IDW and/or remediation waste) is determined to potentially contain COCs, the material will either be managed on site or containerized for transportation to an appropriate disposal site.

On-site management of the waste soil will be allowed only if it is managed within an area of concern and it is appropriate to defer the management of the waste until the final remediation of the site. If this option is chosen, the waste soil shall be protected from run-on and runoff using appropriate protective measures based on the type of contaminant(s) (e.g., covered with plastic and bermed).

Management of soil waste for disposal consists of placing the waste in containers, labeling the containers, temporarily storing the containers until shipped, and shipping the waste to a disposal site. 
The containers, labels, management of stored waste, transport to the disposal site, and disposal shall be appropriate for the type of waste (i.e., low-level hazardous, hydrocarbon, and/or mixed).

Note that soils placed back into a borehole or excavation in the same approximate location from which it originated is not considered to be a waste.

\subsubsection{Management of Debris}

This waste stream (i.e., IDW and/or remediation waste) can vary depending on site conditions. Debris that requires removal for the investigation activities (e.g., soil sampling, excavation, drilling) must be characterized for proper management and disposition. Historical site knowledge, knowledge of the waste generation process, field observations, field-monitoring/screening results, radiological survey/swipe results and/or the analytical results of samples either directly or indirectly associated with the waste may be used to characterize the debris. Debris will be visually inspected for stains, discoloration, and gross contamination. Debris may be deemed reusable, recyclable, sanitary waste, hazardous waste, PCB waste, or low-level waste. Waste that is not sanitary will be entered into an approved waste management system, where it will be managed and dispositioned according to federal, state requirements, and agreements between NNSA/NSO and the State of Nevada. The debris will either be managed on site by berming and covering next to the excavation, or by placement in a container(s). The disposal of debris may be deferred until implementation of corrective action at the site.

\subsubsection{Management of Decontamination Rinsate}

Rinsate at CAU 538 will not be considered potentially hazardous waste unless there is evidence that the rinsate may display a RCRA characteristic. Evidence may include such things as the presence of a visible sheen, $\mathrm{pH}$, or association with equipment/materials used to respond to a release/spill of a hazardous waste/substance. Decontamination rinsate that is potentially hazardous (using associated sample results and/or process knowledge) will be managed as "characteristic" hazardous waste (CFR, 2005a). The regulatory status of the potentially hazardous rinsate will be determined through the application of associated sample results or through direct sampling. If the associated samples do not indicate the presence of hazardous constituents, then the rinsate will be considered to be nonhazardous. 
The disposal of nonhazardous rinsate will be consistent with guidance established in current NNSA/NSO Fluid Management Plans for the NTS as follows:

- Rinsate that is determined to be nonhazardous and contaminated to less than 5x Safe Drinking Water Standards (SDWS) is not restricted as to disposal. Nonhazardous rinsate that is contaminated at $5 \mathrm{x}$ to $10 \mathrm{x}$ SDWS will be disposed of in an established infiltration basin, or solidified and disposed of as sanitary waste or low-level waste.

- Nonhazardous rinsate which is contaminated at greater than 10x SDWS will be disposed of in a lined basin, or solidified and disposed of as sanitary waste or low-level waste.

\subsubsection{Field Screening Waste}

The use of field test kits and/or instruments may result in the generation of small quantities of hazardous wastes. If hazardous waste is produced by field screening, it will be segregated from other IDW and managed in accordance with the hazardous waste regulations (CFR, 2005a). On radiological sites, this may increase the potential to generate mixed waste; however, the generation of a mixed waste will be minimized as much as practicable. In the event a mixed waste is generated, the waste will be managed in accordance with Section 6.2 .5 of this document. 


\subsection{Quality Assurance/Quality Control}

The overall objective of the characterization activities described in this SAFER Plan is to collect accurate and defensible data to support the selection and implementation of a closure alternative for each CAS in CAU 538. Sections 7.1 and 7.2 discuss the collection of required QC samples in the field and quality assurance (QA) requirements for laboratory/analytical data to achieve closure. Unless otherwise stated in this SAFER Plan or required by the results of the DQO process (see Appendix B), this investigation will adhere to the Industrial Sites QAPP (NNSA/NV, 2002b).

\subsection{Sample Collection Activities}

Field QC samples will be collected in accordance with established procedures. Field QC samples are collected and analyzed to aid in determining the validity of environmental sample results. The number of required QC samples depends on the types and number of environmental samples collected. The minimum frequency of collecting and analyzing QC samples for this investigation, as determined in the DQO process, include:

- $\quad$ Trip blanks (1 per sample cooler containing VOC environmental samples)

- Equipment rinsate blanks (1 per sampling event for each type of decontamination procedure)

- Source blanks (1 per lot of source material that contacts sampled media)

- Field duplicates (1 per 20 environmental samples or 1 per CAS per matrix, if less than 20 collected)

- Field blanks (1 per 20 environmental samples and 1 upon changes in site conditions [e.g., exhaust, rain])

- Laboratory QC samples (1 per 20 environmental samples or 1 per CAS per matrix, if less than 20 collected)

Additional QC samples may be submitted based on site conditions at the discretion of the Task Manager or Site Supervisor. Field QC samples shall be analyzed using the same analytical procedures implemented for associated environmental samples. Additional details regarding field QC samples are available in the Industrial Sites QAPP (NNSA/NV, 2002b). 


\subsection{Applicable Laboratory/Analytical Data Quality Indicators}

The DQIs are qualitative and quantitative descriptors used in interpreting the degree of acceptability or utility of data. Data quality indicators are used to evaluate the entire measurement system and laboratory measurement processes (i.e., analytical method performance) as well as to evaluate individual analytical results (i.e., parameter performance). The quality and usability of data used to make DQO decisions will be assessed based on the following DQIs:

- Precision

- Accuracy/bias

- Representativeness

- Comparability

- Completeness

- Sensitivity

Table 7-1 provides the established analytical method/measurement system performance criteria for each of the DQIs and the potential impacts to the decision if the criteria are not met. The following subsections discuss each of the DQIs that will be used to assess the quality of laboratory data. Due to changes in analytical methodology and changes in analytical laboratory contracts, criteria for precision and accuracy in Tables 7-2 and 7-3 that vary from corresponding information in the Industrial Sites QAPP will supersede that information in the Industrial Sites QAPP (NNSA/NV, 2002b).

\subsubsection{Precision}

Precision is used to assess the variability between two equal samples. This is a measure of the repeatability of the analysis process from sample collection through analysis results. Precision is measured as the relative percent difference (RPD) or normalized difference (ND) of duplicate samples as presented in the Industrial Sites QAPP (NNSA/NV, 2002b).

Determinations of precision will be made for field duplicate samples and laboratory duplicate samples. Field duplicate samples will be collected simultaneously with samples from the same source under similar conditions in separate containers. The duplicate sample is independent of the original sample in order to assess field impacts and laboratory performance on precision through a comparison of results. Laboratory precision is evaluated as part of the required laboratory internal 
Table 7-1

Data Quality Indicator Performance Metrics

\begin{tabular}{|c|c|c|}
\hline $\begin{array}{l}\text { Data Quality } \\
\text { Indicator }\end{array}$ & Performance Metric & $\begin{array}{l}\text { Potential Impact on Decision } \\
\text { if Performance Metric Not Met }\end{array}$ \\
\hline Precision & $\begin{array}{l}\text { At least } 80 \% \text { of the sample results for each } \\
\text { measured analyte are not qualified for precision } \\
\text { based on the RPD criteria discussed in } \\
\text { Section } 7.2 .1\end{array}$ & $\begin{array}{l}\text { If the performance metric is not met, the } \\
\text { affected analytical results from each } \\
\text { affected CAS will be assessed to determine } \\
\text { whether there is sufficient confidence in } \\
\text { analytical results to use the data in making } \\
\text { DQO decisions. }\end{array}$ \\
\hline Accuracy & $\begin{array}{l}\text { At least } 80 \% \text { of the sample results for each } \\
\text { measured analyte are not qualified for accuracy } \\
\text { based on the \%R criteria discussed in } \\
\text { Section } 7.2 .2\end{array}$ & $\begin{array}{l}\text { If the performance metric is not met, the } \\
\text { affected analytical results from each } \\
\text { affected CAS will be assessed to determine } \\
\text { whether there is sufficient confidence in } \\
\text { analytical results to use the data in making } \\
\text { DQO decisions. }\end{array}$ \\
\hline Sensitivity & $\begin{array}{l}\text { Laboratory detection limits are less than or equal } \\
\text { to respective FALs. }\end{array}$ & $\begin{array}{l}\text { Cannot determine whether COCs are } \\
\text { present or migrating at levels of concern. }\end{array}$ \\
\hline Comparability & $\begin{array}{l}\text { Sampling, handling, preparation, analysis, } \\
\text { reporting, and data validation are performed } \\
\text { using standard methods and procedures. }\end{array}$ & $\begin{array}{l}\text { Inability to combine data with data obtained } \\
\text { from other sources and/or inability to } \\
\text { compare data to regulatory action levels. }\end{array}$ \\
\hline Representativeness & $\begin{array}{l}\text { Samples contain contaminants at concentrations } \\
\text { present in the environmental media from which } \\
\text { they were collected. }\end{array}$ & $\begin{array}{l}\text { Analytical results will not represent true site } \\
\text { conditions. Inability to make appropriate } \\
\text { DQO decisions. }\end{array}$ \\
\hline Completeness & $\begin{array}{l}80 \% \text { of the CAS-specific COPC analytes have } \\
\text { valid results. } \\
100 \% \text { of CAS-specific targeted analytes have } \\
\text { valid results. }\end{array}$ & $\begin{array}{l}\text { Cannot support/defend decision on whether } \\
\text { COCs are present. }\end{array}$ \\
\hline Extent Completeness & $\begin{array}{l}100 \% \text { of COC analytes used to define extent } \\
\text { have valid results. }\end{array}$ & $\begin{array}{l}\text { Extent of contamination cannot be } \\
\text { accurately determined. }\end{array}$ \\
\hline $\begin{array}{l}\text { Clean Closure } \\
\text { Completeness }\end{array}$ & $100 \%$ of targeted analytes have valid results. & $\begin{array}{l}\text { Cannot determine whether COCs remain in } \\
\text { soil. }\end{array}$ \\
\hline
\end{tabular}

$\mathrm{COC}=$ Contaminant of concern

$\mathrm{COPC}=$ Contaminant of potential concern

$\mathrm{DQO}=$ Data quality objective

$\mathrm{FAL}=$ Final action level

$\mathrm{RPD}=$ Relative percent difference

$\% R=$ Percent recovery

QC program to assess performance of analytical procedures. The laboratory sample duplicates are an aliquot, or subset, of a field sample generated in the laboratory. They are not a separate sample but a split, or portion, of an existing sample. Typically, laboratory duplicate QC samples may include matrix spike duplicate (MSD) and laboratory control sample (LCS) duplicate samples for organic, inorganic, and radiological analyses. 
Table 7-2

Analytical Requirements for Radionuclides for CAU 538

(Page 1 of 2)

\begin{tabular}{|c|c|c|c|c|c|c|}
\hline Parameter/Analyte & Matrix & $\begin{array}{l}\text { Analytical } \\
\text { Method }\end{array}$ & MDC $^{a}$ & $\mathrm{PAL}^{\mathrm{b}, \mathrm{c}}$ & $\begin{array}{l}\text { Laboratory } \\
\text { Precision }\end{array}$ & Percent Recovery \\
\hline \multicolumn{7}{|c|}{ Gamma Spectroscopy } \\
\hline \multirow{2}{*}{ Americium-241 } & Water & EPA $901.1^{\mathrm{d}}$ & $50 \mathrm{pCi} / \mathrm{L}^{\mathrm{e}}$ & $50 \mathrm{pCi} / \mathrm{L}$ & \multirow{2}{*}{$\begin{array}{c}\text { Relative Percent } \\
\text { Difference (RPD) } \\
20 \% \text { water } 35 \% \text { Soil }\end{array}$} & \multirow{4}{*}{$\begin{array}{c}\text { Laboratory Control } \\
\text { Sample Recovery } \\
80-120^{\mathrm{h}} \text { Percent } \\
\text { Recovery (\%R) }\end{array}$} \\
\hline & Soil & HASL-300 & $2.0 \mathrm{pCi} / \mathrm{g}^{\mathrm{e}}$ & $7.62 \mathrm{pCi} / \mathrm{g}$ & & \\
\hline \multirow{2}{*}{ Cesium-137 } & Water & EPA $901.1^{\mathrm{d}}$ & $10 \mathrm{pCi} / \mathrm{L}^{\mathrm{e}}$ & $10 \mathrm{pCi} / \mathrm{L}$ & \multirow{2}{*}{$\begin{array}{c}\text { Normalized Difference } \\
-2<N D<2^{g}\end{array}$} & \\
\hline & Soil & HASL-300 ${ }^{f}$ & $0.5 \mathrm{pCi} / \mathrm{g}^{\mathrm{e}}$ & $7.3 \mathrm{pCi} / \mathrm{g}$ & & \\
\hline \multicolumn{7}{|c|}{ Other Radionuclides } \\
\hline \multirow{2}{*}{ Plutonium-238 } & Water & $\begin{array}{c}\text { ASTM } \\
\text { D3865-02 }\end{array}$ & $0.1 \mathrm{pCi} / \mathrm{L}$ & $0.1 \mathrm{pCi} / \mathrm{L}$ & \multirow{15}{*}{$\begin{array}{c}\text { Relative Percent } \\
\text { Difference (RPD) } \\
20 \% \text { water } 35 \% \text { Soil }\end{array}$} & \multirow{15}{*}{$\begin{array}{c}\text { Laboratory Control } \\
\text { Sample Recovery } \\
80-120^{\mathrm{h}} \text { Percent } \\
\text { Recovery (\%R) } \\
\text { Chemical Yield } 30-105^{\mathrm{j}} \\
\% \mathrm{R}\end{array}$} \\
\hline & Soil & $\begin{array}{c}\text { ASTM } \\
\text { C1001-00k }\end{array}$ & $0.05 \mathrm{pCi} / \mathrm{g}$ & $7.78 \mathrm{pCi} / \mathrm{g}$ & & \\
\hline \multirow{2}{*}{ Plutonium-239/240 } & Water & $\begin{array}{c}\text { ASTM } \\
\text { D3865-02 }\end{array}$ & $0.1 \mathrm{pCi} / \mathrm{L}$ & $0.1 \mathrm{pCi} / \mathrm{L}$ & & \\
\hline & Soil & $\begin{array}{c}\text { ASTM } \\
\text { C1001-00k }\end{array}$ & $0.05 \mathrm{pCi} / \mathrm{g}$ & $7.62 \mathrm{pCi} / \mathrm{g}$ & & \\
\hline \multirow[t]{2}{*}{ Strontium-90 } & Water & $\begin{array}{c}\text { ASTM } \\
\text { D5811-00' }\end{array}$ & $1.0 \mathrm{pCi} / \mathrm{L}$ & $1.0 \mathrm{pCi} / \mathrm{L}$ & & \\
\hline & Soil & HASL $300^{\dagger}$ & $0.5 \mathrm{pCi} / \mathrm{g}$ & $503.0 \mathrm{pCi} / \mathrm{g}$ & & \\
\hline \multirow[t]{2}{*}{ Uranium-234 } & Water & $\begin{array}{c}\text { ASTM } \\
\text { D3972-02 }\end{array}$ & $0.1 \mathrm{pCi} / \mathrm{L}$ & $0.1 \mathrm{pCi} / \mathrm{L}$ & & \\
\hline & Soil & $\mathrm{C} 1000-02^{n}$ & $0.05 \mathrm{pCi} / \mathrm{g}$ & $85.9 \mathrm{pCi} / \mathrm{g}$ & & \\
\hline \multirow[t]{2}{*}{ Uranium-235 } & Water & $\begin{array}{c}\text { ASTM } \\
\text { D3972-02 }\end{array}$ & $0.1 \mathrm{pCi} / \mathrm{L}$ & $0.1 \mathrm{pCi} / \mathrm{L}$ & & \\
\hline & Soil & $\mathrm{C} 1000-02^{\mathrm{n}}$ & $0.05 \mathrm{pCi} / \mathrm{g}$ & $10.5 \mathrm{pCi} / \mathrm{g}$ & & \\
\hline \multirow[t]{2}{*}{ Uranium-238 } & Water & $\begin{array}{c}\text { ASTM } \\
\text { D3972-02 }\end{array}$ & $0.1 \mathrm{pCi} / \mathrm{L}$ & $0.1 \mathrm{pCi} / \mathrm{L}$ & & \\
\hline & Soil & $\mathrm{C} 1000-02^{\mathrm{n}}$ & $0.05 \mathrm{pCi} / \mathrm{g}$ & $63.2 \mathrm{pCi} / \mathrm{g}$ & & \\
\hline Tritium & Water & EPA $906.0^{\mathrm{d}}$ & $400 \mathrm{pCi} / \mathrm{L}$ & $400,000 \mathrm{pCi} / \mathrm{L}^{\circ}$ & & \\
\hline Gross Alpha & Water & EPA $900.0^{\mathrm{d}}$ & $3 \mathrm{pCi} / \mathrm{L}$ & $\mathrm{N} / \mathrm{A}$ & & \\
\hline Gross Beta & Water & EPA $900.0^{\mathrm{d}}$ & $4 \mathrm{pCi} / \mathrm{L}$ & N/A & & \\
\hline
\end{tabular}


Table 7-2

\section{Analytical Requirements for Radionuclides for CAU 538} (Page 2 of 2)

\begin{tabular}{|c|c|c|c|c|c|c|}
\hline Parameter/Analyte & Matrix & $\begin{array}{c}\text { Analytical } \\
\text { Method }\end{array}$ & MDC $^{a}$ & PAL $^{\mathrm{b}, \mathrm{c}}$ & $\begin{array}{l}\text { Laboratory } \\
\text { Precision }\end{array}$ & Percent Recovery \\
\hline
\end{tabular}

aThe MDC is the lowest concentration of a radionuclide, if present in a sample, that can be detected with a 95 percent confidence level.

'The PALs for soil are based on the National Council on Radiation Protection and Measurement (NCRP) Report No. 129

"Recommended Screening Limits for Contaminated Surface Soil and Review of Factors Relevant to Site-Specific Studies" (NCRP, 1999) based on 25 mrem/yr dose (Murphy, 2004) and the guidelines for residual concentration of radionuclides in DOE Order 5400.5 (DOE, 1993).

'The PALs for liquids are set equal to the MDC.

dPrescribed Procedures for Measurements of Radioactivity in Drinking Water, EPA-600/4-80-032 (EPA, 1980)

eMDCs vary depending on the presence of other gamma-emitting radionuclides in the sample and are relative to the MDC for cesium-137.

${ }^{\mathrm{f}}$ Environmental Measurements Laboratory Procedures Manual, HASL-300 (DOE, 1997)

${ }^{g} \mathrm{ND}$ is not RPD, it is another measure of precision used to evaluate duplicate analyses. The ND is calculated as the difference between two results divided by the square root of the sum of the squares of their total propagated uncertainties. Evaluation of Radiochemical Data Usability (Paar and Porterfield, 1997)

hEPA Contract Laboratory Program Statement of Work for Inorganic Analysis (EPA, 1988a; 1994b; and 1995)

'Standard Test Method for Plutonium in Water (ASTM, 2002b)

j General Radiochemistry and Routine Analytical Services Protocol (GRASP) (EG\&G Rocky Flats, 1991). The chemical yield only applies to plutonium, uranium, and strontium.

${ }^{k}$ Standard Test Method for Radiochemical Determination of Plutonium in Soil by Alpha Spectroscopy (ASTM, 2000a)

'Standard Test Method for Strontium-90 in Water (ASTM, 2000b).

${ }^{\mathrm{m}}$ Standard Test Method for Isotopic Uranium in Water by Radiochemistry (ASTM, 2002a)

"Standard Test Method for Radiochemical Determination of Uranium Isotopes in Soil by Alpha Spectrometry (ASTM, 2002c)

${ }^{\circ}$ The PAL for tritium is based on the UGTA Project limit of $400,000 \mathrm{pCi} / \mathrm{L}$ for discharge of water containing tritium to an infiltration basin/area (NNSA/NV, 2002a)

ASTM = American Society for Testing and Materials $\mathrm{EPA}=\mathrm{U} . \mathrm{S}$. Environmental Protection Agency

HASL $=$ Health and Safety Laboratory

$\mathrm{pCi} / \mathrm{L}=$ Picocuries per liter

MDC = Minimum detectable concentration $\mathrm{mrem} / \mathrm{yr}=$ Millirem per year

N/A = Not applicable

ND = Normalized difference

$\mathrm{PAL}=$ Preliminary action level

$\mathrm{pCi} / \mathrm{g}=$ Picocuries per gram 
Table 7-3

\section{Analytical Requirements for Nonradiological Analytes for CAU $538^{1}$}

(Page 1 of 3)

\begin{tabular}{|c|c|c|c|c|c|c|}
\hline Parameter/Analyte & $\begin{array}{c}\text { Medium } \\
\text { or } \\
\text { Matrix }\end{array}$ & $\begin{array}{l}\text { Analytical } \\
\text { Method }\end{array}$ & $\begin{array}{l}\text { Minimum } \\
\text { Reporting Limit }\end{array}$ & $\begin{array}{c}\text { RCRA Hazardous } \\
\text { Waste Regulatory } \\
\text { Limit }\end{array}$ & $\begin{array}{l}\text { Laboratory } \\
\text { Precision }^{\mathrm{a}}\end{array}$ & $\begin{array}{l}\text { Percent Recovery } \\
(\% R)^{b}\end{array}$ \\
\hline \multicolumn{7}{|c|}{ ORGANICS } \\
\hline \multirow{2}{*}{$\begin{array}{l}\text { Total Volatile Organic } \\
\text { Compounds (VOCs) }\end{array}$} & Water & \multirow{2}{*}{$8260 B^{c}$} & \multirow{2}{*}{$\begin{array}{l}\text { Parameter-specific } \\
\text { estimated } \\
\text { quantitation limits }^{\mathrm{d}}\end{array}$} & \multirow{2}{*}{$\mathrm{N} / \mathrm{A}$} & \multirow{2}{*}{ Lab-specific $^{\mathrm{e}}$} & \multirow{2}{*}{ Lab-specific $^{\mathrm{e}}$} \\
\hline & Soil & & & & & \\
\hline \multicolumn{7}{|l|}{$\begin{array}{l}\text { Toxicity Characteristic Leaching } \\
\text { Procedure (TCLP) VOCs }\end{array}$} \\
\hline Benzene & \multirow{10}{*}{ Aqueous } & \multirow{10}{*}{$1311 / 8260 B^{C}$} & $0.050 \mathrm{mg} / \mathrm{L}^{\mathrm{d}}$ & $0.5 \mathrm{mg} / \mathrm{L}^{\dagger}$ & \multirow{10}{*}{ Lab-specific $^{\mathrm{e}}$} & \multirow{10}{*}{ Lab-specific $^{\mathrm{e}}$} \\
\hline Carbon Tetrachloride & & & $0.050 \mathrm{mg} / \mathrm{L}^{\mathrm{d}}$ & $0.5 \mathrm{mg} / \mathrm{L}^{\dagger}$ & & \\
\hline Chlorobenzene & & & $0.050 \mathrm{mg} / \mathrm{L}^{\mathrm{d}}$ & $100 \mathrm{mg} / \mathrm{L}^{\mathrm{f}}$ & & \\
\hline Chloroform & & & $0.050 \mathrm{mg} / \mathrm{L}^{\mathrm{d}}$ & $6 \mathrm{mg} / \mathrm{L}^{\dagger}$ & & \\
\hline 1,2-Dichloroethane & & & $0.050 \mathrm{mg} / \mathrm{L}^{\mathrm{d}}$ & $0.5 \mathrm{mg} / \mathrm{L}^{\dagger}$ & & \\
\hline 1,1-Dichloroethene & & & $0.050 \mathrm{mg} / \mathrm{L}^{\mathrm{d}}$ & $0.7 \mathrm{mg} / \mathrm{L}^{\dagger}$ & & \\
\hline Methyl Ethyl Ketone & & & $0.2 \mathrm{mg} / \mathrm{L}^{\mathrm{d}}$ & $200 \mathrm{mg} / \mathrm{L}^{\dagger}$ & & \\
\hline Tetrachloroethene & & & $0.050 \mathrm{mg} / \mathrm{L}^{\mathrm{d}}$ & $0.7 \mathrm{mg} / \mathrm{L}^{\dagger}$ & & \\
\hline Trichloroethene & & & $0.050 \mathrm{mg} / \mathrm{L}^{\mathrm{d}}$ & $0.5 \mathrm{mg} / \mathrm{L}^{\dagger}$ & & \\
\hline Vinyl Chloride & & & $0.050 \mathrm{mg} / \mathrm{L}^{\mathrm{d}}$ & $0.2 \mathrm{mg} / \mathrm{L}^{\dagger}$ & & \\
\hline \multirow{2}{*}{$\begin{array}{l}\text { Total Semivolatile Organic } \\
\text { Compounds (SVOCs) }\end{array}$} & Water & \multirow{2}{*}{$8270 C^{c}$} & \multirow{2}{*}{$\begin{array}{c}\text { Parameter-specific } \\
\text { estimated } \\
\text { quantitation limits }^{d}\end{array}$} & \multirow{2}{*}{ N/A } & \multirow{2}{*}{ Lab-specific $^{\mathrm{e}}$} & \multirow{2}{*}{ Lab-specific $^{e}$} \\
\hline & Soil & & & & & \\
\hline \multicolumn{7}{|l|}{ TCLP SVOCs } \\
\hline o-Cresol & \multirow{14}{*}{ Aqueous } & \multirow{14}{*}{$1311 / 8270 C^{c}$} & $0.10 \mathrm{mg} / \mathrm{L}^{\mathrm{d}}$ & $200 \mathrm{mg} / \mathrm{L}^{\top}$ & \multirow{14}{*}{ Lab-specific $^{\mathrm{e}}$} & \multirow{14}{*}{ Lab-specific $^{e}$} \\
\hline $\mathrm{m}$-Cresol & & & $0.10 \mathrm{mg} / \mathrm{L}^{\mathrm{d}}$ & $200 \mathrm{mg} / \mathrm{L}^{\dagger}$ & & \\
\hline p-Cresol & & & $0.10 \mathrm{mg} / \mathrm{L}^{\mathrm{d}}$ & $200 \mathrm{mg} / \mathrm{L}^{\dagger}$ & & \\
\hline Cresol (total) & & & $0.30 \mathrm{mg} / \mathrm{L}^{\mathrm{d}}$ & $200 \mathrm{mg} / \mathrm{L}^{\dagger}$ & & \\
\hline 1,4-Dichlorobenzene & & & $0.10 \mathrm{mg} / \mathrm{L}^{\mathrm{d}}$ & $7.5 \mathrm{mg} / \mathrm{L}^{\dagger}$ & & \\
\hline 2,4-Dinitrotoluene & & & $0.10 \mathrm{mg} / \mathrm{L}^{\mathrm{d}}$ & $0.13 \mathrm{mg} / \mathrm{L}^{\dagger}$ & & \\
\hline Hexachlorobenzene & & & $0.10 \mathrm{mg} / \mathrm{L}^{\mathrm{d}}$ & $0.13 \mathrm{mg} / \mathrm{L}^{\dagger}$ & & \\
\hline Hexachlorobutadiene & & & $0.10 \mathrm{mg} / \mathrm{L}^{\mathrm{d}}$ & $0.5 \mathrm{mg} / \mathrm{L}^{\top}$ & & \\
\hline Hexachloroethane & & & $0.10 \mathrm{mg} / \mathrm{L}^{\mathrm{d}}$ & $3 \mathrm{mg} / \mathrm{L}^{\dagger}$ & & \\
\hline Nitrobenzene & & & $0.10 \mathrm{mg} / \mathrm{L}^{\mathrm{d}}$ & $2 \mathrm{mg} / \mathrm{L}^{\dagger}$ & & \\
\hline Pentachlorophenol & & & $0.50 \mathrm{mg} / \mathrm{L}^{\mathrm{d}}$ & $100 \mathrm{mg} / \mathrm{L}^{\dagger}$ & & \\
\hline Pyridine & & & $0.50 \mathrm{mg} / \mathrm{L}^{\mathrm{d}}$ & $5 \mathrm{mg} / \mathrm{L}^{\dagger}$ & & \\
\hline 2,4,5-Trichlorophenol & & & $0.50 \mathrm{mg} / \mathrm{L}^{\mathrm{d}}$ & $400 \mathrm{mg} / \mathrm{L}^{\dagger}$ & & \\
\hline 2,4,6-Trichlorophenol & & & $0.10 \mathrm{mg} / \mathrm{L}^{\mathrm{d}}$ & $2 \mathrm{mg} / \mathrm{L}^{\dagger}$ & & \\
\hline \multirow{2}{*}{$\begin{array}{l}\text { Polychlorinated Biphenyls } \\
\text { (PCBs) }\end{array}$} & Water & \multirow{2}{*}{$8082^{c}$} & \multirow{2}{*}{$\begin{array}{l}\text { Parameter-specific } \\
(\text { (CRQL) })^{\mathrm{g}}\end{array}$} & N/A & Lah_cnecifice & Lh_cnerifice $e^{e}$ \\
\hline & Soil & & & N/A & Lab-specifıc & LaD-speclitc \\
\hline & $\begin{array}{c}\text { Water } \\
\text { Gasoline }\end{array}$ & & $0.1 \mathrm{mg} / \mathrm{L}^{\mathrm{h}}$ & & & \\
\hline $\begin{array}{l}\text { Total Petroleum Hydrocarbons } \\
\text { (Diesel-Range Organics and } \\
\text { Gasoline-Range Orqanics) }\end{array}$ & $\begin{array}{c}\text { Soil } \\
\text { Gasoline }\end{array}$ & modified $^{\mathrm{c}}$ & $1.0 \mathrm{mg} / \mathrm{kg}^{\mathrm{h}}$ & $\mathrm{N} / \mathrm{A}$ & Lab-specific $^{\mathrm{e}}$ & Lab-specific $^{\mathrm{e}}$ \\
\hline$\left[\mathrm{C}_{6}-\mathrm{C}_{38}\right]$ & $\begin{array}{l}\text { Water } \\
\text { Diesel }\end{array}$ & & $0.5 \mathrm{mg} / \mathrm{L}^{\mathrm{h}}$ & & & \\
\hline & Soil Diesel & & $25 \mathrm{mg} / \mathrm{kg}^{\mathrm{h}}$ & & & \\
\hline Tatal Pesticides & Aqueous & $8081 A^{c}$ & Parameter-specific & & Lhangrifie e & Sh-angrifie e \\
\hline Total Pesticides & Soil & $8081 A^{\circ}$ & $\begin{array}{l}\text { estimated } \\
\text { quantitation limits }^{\mathrm{g}}\end{array}$ & N/A & Lab-specific & Lab-specific \\
\hline
\end{tabular}


Table 7-3

Analytical Requirements for Nonradiological Analytes for CAU $538^{1}$ (Page 2 of 3 )

\begin{tabular}{|c|c|c|c|c|c|c|}
\hline Parameter/Analyte & $\begin{array}{l}\text { Medium } \\
\text { or } \\
\text { Matrix }\end{array}$ & $\begin{array}{l}\text { Analytical } \\
\text { Method }\end{array}$ & $\begin{array}{c}\text { Minimum } \\
\text { Reporting Limit }\end{array}$ & $\begin{array}{c}\text { RCRA Hazardous } \\
\text { Waste Regulatory } \\
\text { Limit }\end{array}$ & $\begin{array}{l}\text { Laboratory } \\
\text { Precision }^{\mathrm{a}}\end{array}$ & $\begin{array}{c}\text { Percent Recovery } \\
(\% R)^{\mathrm{b}}\end{array}$ \\
\hline \multicolumn{7}{|l|}{$\overline{\text { TCLP Pesticides }}$} \\
\hline Chlordane (Technical) & Aqueous & \multirow{7}{*}{$1311 / 8081^{c}$} & $0.01 \mathrm{mg} / \mathrm{L}^{\mathrm{g}}$ & $0.03 \mathrm{mg} / \mathrm{L}^{\dagger}$ & \multirow{7}{*}{ Lab-specific $^{e}$} & \multirow{7}{*}{ Lab-specific $^{\mathrm{e}}$} \\
\hline Endrin & & & $0.0015 \mathrm{mg} / \mathrm{L}^{\mathrm{g}}$ & $0.02 \mathrm{mg} / \mathrm{L}^{\dagger}$ & & \\
\hline Heptachlor & & & $0.0005 \mathrm{mg} / \mathrm{L}^{\mathrm{g}}$ & $0.008 \mathrm{mg} / \mathrm{L}^{\dagger}$ & & \\
\hline \multicolumn{2}{|l|}{ Heptachlor Epoxide } & & $0.0005 \mathrm{mg} / \mathrm{L}^{\mathrm{g}}$ & $0.008 \mathrm{mg} / \mathrm{L}^{\dagger}$ & & \\
\hline $\begin{array}{c}\text { Lindane } \\
(\text { Gamma-BCH) }\end{array}$ & & & $0.0005 \mathrm{mg} / \mathrm{L}^{\mathrm{g}}$ & $0.4 \mathrm{mg} / \mathrm{L}^{\mathrm{f}}$ & & \\
\hline Methoxychlor & & & $0.005 \mathrm{mg} / \mathrm{L}^{\mathrm{g}}$ & $10.0 \mathrm{mg} / \mathrm{L}^{\dagger}$ & & \\
\hline Toxaphene & & & $0.05 \mathrm{mg} / \mathrm{L}^{\mathrm{g}}$ & $0.5 \mathrm{mg} / \mathrm{L}^{\top}$ & & \\
\hline \multicolumn{7}{|c|}{ INORGANICS } \\
\hline \multicolumn{7}{|l|}{$\begin{array}{c}\text { Total RCRA Metals, plus } \\
\text { Beryllium }\end{array}$} \\
\hline \multirow{2}{*}{ Arsenic } & Water & $6010 B^{C}$ & $0.01 \mathrm{mg} / \mathrm{L}^{\mathrm{h}, \mathrm{I}}$ & \multirow{16}{*}{$\mathrm{N} / \mathrm{A}$} & $20^{1}$ & \multirow{16}{*}{$\begin{array}{c}\text { Matrix Spike } \\
\text { Recovery } \\
75-125^{i} \\
\\
\text { Laboratory Control } \\
\text { Sample Recovery } \\
80-120^{i}\end{array}$} \\
\hline & Soil & $6010 B^{C}$ & $1 \mathrm{mg} / \mathrm{kg}^{\mathrm{h,1}}$ & & $35^{n}$ & \\
\hline \multirow{2}{*}{ Barium } & Water & $6010 B^{C}$ & $0.20 \mathrm{mg} / \mathrm{L}^{\mathrm{h}, \mathrm{I}}$ & & $20^{1}$ & \\
\hline & Soil & $6010 B^{C}$ & $20 \mathrm{mg} / \mathrm{kg}^{\mathrm{h}, \mathrm{l}}$ & & $35^{h}$ & \\
\hline \multirow{2}{*}{ Beryllium } & Water & $6010 B^{C}$ & $0.005 \mathrm{mg} / \mathrm{L}^{\mathrm{h}, \mathrm{I}}$ & & $20^{1}$ & \\
\hline & Soil & $6010 B^{C}$ & $0.5 \mathrm{mg} / \mathrm{kg}^{\mathrm{h}, \mathrm{l}}$ & & $35^{h}$ & \\
\hline \multirow{2}{*}{ Cadmium } & Water & $6010 B^{C}$ & $0.005 \mathrm{mg} / \mathrm{L}^{\mathrm{h}, \mathrm{I}}$ & & $20^{1}$ & \\
\hline & Soil & $6010 B^{C}$ & $0.5 \mathrm{mg} / \mathrm{L}^{\mathrm{h}, \mathrm{I}}$ & & $35^{n}$ & \\
\hline \multirow{2}{*}{ Chromium } & Water & $6010 B^{C}$ & $0.01 \mathrm{mg} / \mathrm{L}^{\mathrm{n}, 1}$ & & $20^{\prime}$ & \\
\hline & Soil & $6010 B^{C}$ & $1 \mathrm{mg} / \mathrm{kg}^{\mathrm{h}, \mathrm{I}}$ & & $35^{h}$ & \\
\hline \multirow{2}{*}{ Lead } & Water & $6010 B^{C}$ & $0.003 \mathrm{mg} / \mathrm{L}^{\mathrm{h}, \mathrm{I}}$ & & $20^{1}$ & \\
\hline & Soil & $6010 B^{C}$ & $0.3 \mathrm{mg} / \mathrm{kg}^{\mathrm{h}, \mathrm{l}}$ & & $35^{h}$ & \\
\hline \multirow{2}{*}{ Mercury } & Water & $7470 A^{C}$ & $0.0002 \mathrm{mg} / \mathrm{L}^{\mathrm{h}, \mathrm{I}}$ & & $20^{\prime}$ & \\
\hline & Soil & $7471 A^{C}$ & $0.1 \mathrm{mg} / \mathrm{kg}^{\mathrm{h}, \mathrm{I}}$ & & $35^{n}$ & \\
\hline \multirow{2}{*}{ Selenium } & Water & $6010 B^{C}$ & $0.005 \mathrm{mg} / \mathrm{L}^{\mathrm{h}, \mathrm{l}}$ & & $20^{1}$ & \\
\hline & Soil & $6010 B^{C}$ & $0.5 \mathrm{mg} / \mathrm{kg}^{\mathrm{h}, \mathrm{l}}$ & & $35^{h}$ & \\
\hline \multirow[b]{2}{*}{ Silver } & Water & $6010 B^{C}$ & $0.01 \mathrm{mg} / \mathrm{L}^{\mathrm{h}, \mathrm{I}}$ & \multirow[b]{2}{*}{$\mathrm{N} / \mathrm{A}$} & $20^{1}$ & \multirow{2}{*}{$\begin{array}{c}\text { Matrix Spike } \\
\text { Recovery } \\
75-125^{i} \\
\\
\text { Laboratory Control } \\
\text { Sample Recovery } \\
80-120^{i}\end{array}$} \\
\hline & Soil & $6010 B^{C}$ & $1 \mathrm{mg} / \mathrm{kg}^{\mathrm{h}, \mathrm{i}}$ & & $35^{h}$ & \\
\hline \multicolumn{7}{|l|}{ TCLP RCRA Metals } \\
\hline Arsenic & \multirow{8}{*}{ Aqueous } & \multirow{8}{*}{$\begin{array}{l}1311 / 6010 B^{C} \\
1311 / 7470 A^{c}\end{array}$} & $0.10 \mathrm{mg} / \mathrm{L}^{\mathrm{h}, \mathrm{I}}$ & $5 \mathrm{mg} / \mathrm{L}^{\dagger}$ & & \multirow{8}{*}{$\begin{array}{c}\text { Laboratory Control } \\
\text { Sample Recovery } \\
80-120^{i}\end{array}$} \\
\hline Barium & & & $2 \mathrm{mg} / \mathrm{L}^{\mathrm{h}, \mathrm{I}}$ & $100 \mathrm{mg} / \mathrm{L}^{\dagger}$ & & \\
\hline Cadmium & & & $0.05 \mathrm{mg} / \mathrm{L}^{\mathrm{h}, \mathrm{I}}$ & $1 \mathrm{mg} / \mathrm{L}^{\dagger}$ & & \\
\hline Chromium & & & $0.1 \mathrm{mg} / \mathrm{L}^{\mathrm{h}, \mathrm{l}}$ & $5 \mathrm{mg} / \mathrm{L}^{\dagger}$ & أهم & \\
\hline Lead & & & $0.03 \mathrm{mg} / \mathrm{L}^{\mathrm{h}, \mathrm{l}}$ & $5 \mathrm{mg} / \mathrm{L}^{\dagger}$ & 20 & \\
\hline Mercury & & & $0.002 \mathrm{mg} / \mathrm{L}^{\mathrm{h}, \mathrm{I}}$ & $0.2 \mathrm{mg} / \mathrm{L}^{\mathrm{f}}$ & & \\
\hline Selenium & & & $0.05 \mathrm{mg} / \mathrm{L}^{\mathrm{h}, \mathrm{l}}$ & $1 \mathrm{mg} / \mathrm{L}^{\mathrm{f}}$ & & \\
\hline Silver & & & $0.1 \mathrm{mg} / \mathrm{L}^{\mathrm{h}, \mathrm{I}}$ & $5 \mathrm{mg} / \mathrm{L}^{\dagger}$ & & \\
\hline
\end{tabular}


Table 7-3

Analytical Requirements for Nonradiological Analytes for CAU $538^{1}$ (Page 3 of 3 )

\begin{tabular}{|c|c|c|c|c|c|c|}
\hline Parameter/Analyte & $\begin{array}{c}\text { Medium } \\
\text { or } \\
\text { Matrix }\end{array}$ & $\begin{array}{c}\text { Analytical } \\
\text { Method }\end{array}$ & $\begin{array}{c}\text { Minimum } \\
\text { Reporting Limit }\end{array}$ & $\begin{array}{c}\text { RCRA Hazardous } \\
\text { Waste Regulatory } \\
\text { Limit }\end{array}$ & $\begin{array}{c}\text { Laboratory } \\
\text { Precision }^{\mathrm{a}}\end{array}$ & $\begin{array}{c}\text { Percent Recovery } \\
(\% R)^{\mathrm{b}}\end{array}$ \\
\hline
\end{tabular}

Footnotes:

1. See Table 7-2 for the analytical requirements for radionuclides.

${ }^{\text {a }}$ Relative percent difference (RPD) is used to calculate precision. Precision is estimated from the RPD of the concentrations measured for the matrix spike and matrix spike duplicate or of laboratory, or field duplicates of unspiked samples. It is calculated by: $R P D=100 x$ $\left\{\left(\left|A_{1}-A_{2}\right|\right) /\left[\left(A_{1}+A_{2}\right) / 2\right]\right\}$, where $A_{1}=$ Concentration of the parameter in the initial sample aliquot, $A_{2}=$ Concentration of the parameter in the duplicate sample aliquot.

${ }^{b}$ The $\% R$ is used to calculate accuracy. Accuracy is assessed from the recovery of parameters spiked into a blank or sample matrix of interest, or from the recovery of surrogate compounds spiked into each sample. The recovery of each spiked parameter is calculated by: $\% R=100 \times\left(A_{s}-A_{u} / A_{n}\right)$, where $A_{s}=$ Concentration of the parameter in the spiked sample, $A_{u}=$ Concentration of the parameter in the unspiked sample, $A_{n}=$ Concentration increase that should result from spiking the sample.

c The EPA Test Methods for Evaluating Solid Waste Physical/Chemical Methods, 3rd Edition, Parts 1-4, (SW-846) CD ROM, Washington, DC (EPA, 1996).z

${ }^{\mathrm{d}}$ Estimated Quantitation Limit as given in SW-846 (EPA, 1996).

${ }^{\mathrm{e}}$ In-House Generated RPD and \%R Performance Criteria. It is necessary for laboratories to develop in-house performance criteria and compare them to those in the methods. The laboratory begins by analyzing 15 to 20 samples of each matrix and calculating the mean $\% \mathrm{R}$ for each parameter. The standard deviation (SD) of each \% $\mathrm{R}$ is then calculated, and the warning and control limits for each parameter are established at $\pm 2 \mathrm{SD}$ and $\pm 3 \mathrm{SD}$ from the mean, respectively. If the warning limit is exceeded during the analysis of any sample delivery group (SDG), the laboratory institutes corrective action to bring the analytical system back into control. If the control limit is exceeded, the sample results for that SDG are considered unacceptable. These limits are reviewed after every quarter and are updated when necessary. The laboratory tracks trends in both performance and control limits by the use of control charts. The laboratory's compliance with these requirements is confirmed as part of an annual laboratory audit. Similar procedures are followed in order to generate acceptance criteria for precision measurements.

${ }^{f}$ Title 40 Code of Federal Regulations (CFR) Part 261, "Identification and Listing of Hazardous Waste" (CFR, 2005a)

${ }^{9}$ EPA Contract Laboratory Program (CLP) Statement of Work for Organic Analysis (EPA, 1988b; 1991; and 1994b)

${ }^{\mathrm{h}}$ Industrial Sites Quality Assurance Project Plan (NNSA/NV, 2002b)

'EPA Contract Laboratory Program Statement of Work for Inorganic Analysis (EPA, 1988a; 1994a; and 1995)

$\mathrm{C}=$ Carbon

$\mathrm{CRQL}=$ Contract-required quantitative limits

$\mathrm{mg} / \mathrm{kg}=$ Milligrams per kilogram

$\mathrm{mg} / \mathrm{L}=$ Milligrams per liter

$\mathrm{N} / \mathrm{A}=$ Not applicable 
Precision is a quantitative measure used to assess overall analytical method and field sampling performance as well as to assess the need to "flag" (qualify) individual parameter results when corresponding QC sample results are not within established control limits. The RPD and ND criteria to be used for assessment of precision for laboratory duplicates are the parameter-specific criteria listed in Tables 7-2 and 7-3. The performance metric for assessing the DQI of precision on DQO decisions (see Table 7-1) is that 80 percent of sample results for each measured analyte are not qualified due to precision based on the analytical method-specific and laboratory-specific criteria presented in Tables 7-2 and 7-3. If this performance metric is not met, an assessment will be conducted in the CR on the impacts to DQO decisions specific to affected analytes and CASs. Any RPD or ND values outside the specified criteria do not necessarily result in the qualification of analytical data. It is only one factor in making an overall judgment about the quality of the reported analytical results.

\subsubsection{Accuracy/Bias}

Accuracy is a measure of the closeness of an individual measurement or the average of a number of measurements to the true value. It is used to assess the performance of laboratory measurement processes as well as to evaluate individual groups of analyses (i.e., sample delivery groups).

Accuracy is determined by analyzing a reference material of known parameter concentration or by reanalyzing a sample to which a material of known concentration or amount of parameter has been added (spiked). Accuracy will be evaluated based on results from three types of spiked samples: matrix spike (MS), LCS, and surrogates. The LCS sample is analyzed with the field samples using the same sample preparation, reagents, and analytical methods employed for the samples. One LCS will be prepared with each batch of samples for analysis by a specific measurement.

The criteria for chemical analyses to be used for assessment of accuracy are the parameter-specific criteria listed in Table 7-3. The percent recovery criteria for radiochemical analyses to be used for assessment of accuracy will be the control limits listed in Table 7-2.

The performance metric for assessing the DQI of accuracy on DQO decisions (see Table 7-1) is that at least 80 percent of the samples are not qualified for exceeding percent recovery criteria for each measured analyte. If this performance is not met, an assessment will be conducted in the CR on the 
impacts to DQO decisions specific to affected analytes and CASs. Any percent recovery values outside the specified criteria do not necessarily result in the qualification of analytical data. It is only one factor in making an overall judgment about the quality of the reported analytical results. Factors beyond the laboratory's control, such as sample matrix effects, can cause the measured values to be outside of the established criteria. Therefore, the entire sampling and analytical process may be evaluated when determining the usability of the affected data.

\subsubsection{Representativeness}

Representativeness is the degree to which sample characteristics accurately and precisely represent characteristics of a population or an environmental condition (EPA, 2002). Representativeness is assured by developing the sampling strategy during the DQO process such that false negative and false positive decision errors are minimized. The criteria listed in DQO Step 6 - Specify the Tolerable Limits on Decision Errors are:

- For Decision I, having a high degree of confidence that the sample locations selected will identify COCs if present anywhere within the CAS.

- Having a high degree of confidence that analyses conducted will be sufficient to detect any COCs present in the samples.

- For Decision II, having a high degree of confidence that the sample locations selected will identify the extent of COCs.

These are qualitative measures that will be used to assess measurement system performance for representativeness. The assessment of this qualitative criterion will be presented in the $\mathrm{CR}$.

\subsubsection{Comparability}

Comparability is a qualitative parameter expressing the confidence with which one dataset can be compared to another (EPA, 2002). The criteria for the evaluation of comparability will be that all sampling, handling, preparation, analysis, reporting, and data validation were performed using approved standard methods and procedures. This will ensure that data from this project can be compared to regulatory action levels that were developed based on data generated using the same or comparable methods and procedures. An evaluation of comparability will be presented in the CR. 


\subsubsection{Completeness}

Completeness is defined as generating sufficient data of the appropriate quality to satisfy the data needs identified in the DQOs. For judgmental sampling, completeness will be evaluated using both a quantitative measure and a qualitative assessment. The quantitative measurement to be used to evaluate completeness is presented in Table 7-1 and is based on the percentage of measurements made that are judged to be valid. The completeness goal for targeted analytes and the remaining COPCs is 100 percent and 80 percent, respectively. If these criteria are not achieved, the dataset will be assessed for potential impacts on making DQO decisions.

The qualitative assessment of completeness is an evaluation of the sufficiency of information available to make DQO decisions. This assessment will be based on meeting the data needs identified in the DQOs and will be presented in the CR.

\subsubsection{Sensitivity}

Sensitivity is the capability of a method or instrument to discriminate between measurement responses representing different levels of the variable of interest (EPA, 2001). The evaluation criteria for this parameter will be that measurement sensitivity (detection limits) will be less than or equal to the corresponding FALs. If this criterion is not achieved, the affected data will be assessed for usability and potential impacts on meeting site characterization objectives. This assessment will be presented in the $\mathrm{CR}$. 


\subsection{References}

ASTM, see American Society for Testing and Materials.

American Aerial Surveys, Inc., 1968. Aerial photograph U2y_Post-Test_8 of CAU 538, CAS 02-21-01. 18 January.

American Society for Testing and Materials. 1995. Standard Guide for Risk-Based Corrective Action Applied at Petroleum Release Sites/American Society for Testing and Materials, ASTM E1739-95 (Reapproved 2002). Philadelphia, PA.

American Society for Testing and Materials. 2000a. Standard Test Method for Radiochemical Determination of Plutonium in Soil by Alpha Spectroscopy, C1001-2000. Philadelphia, PA.

American Society for Testing and Materials. 2000b. Standard Test Method for Strontium-90 in Water, D5811-2000. Philadelphia, PA.

American Society for Testing and Materials. 2002a. Standard Test Method for Isotopic Uranium in Water by Radiochemistry, D3972-2002. Philadelphia, PA.

American Society for Testing and Materials. 2002b. Standard Test Method for Plutonium in Water, D3865-02. Philadelphia, PA.

American Society for Testing and Materials. 2002c. Standard Test Method for Radiochemical Determination of Uranium Isotopes in Soil by Alpha Spectroscopy, C1000-2000.

Philadelphia, PA.

BN, see Bechtel Nevada.

Bechtel Nevada. 1995. Nevada Test Site Performance Objective for Certification of Nonradioactive Hazardous Waste, G-E11/96.01, Rev. 0. Las Vegas, NV.

Bechtel Nevada. 1999a. An Aerial Radiological Survey of the Nevada Test Site, Nevada Test Site, Nevada: Survey Dates--August to September 1994, December. Prepared by T.J. Hendricks, and S.R. Riedhauser for U.S. Department of Energy. DOE/NV/11718--324.

Las Vegas, NV: Bechtel Nevada.

Bechtel Nevada. 1999b. Engineering drawing number JS-090-088-C12, entitled, "Nevada Test Site_Areas 6 \& 23 Installation of Five Aboveground Tanks 6-CP-9 \& Piping Plan," 23 March. Las Vegas, NV. 
Bechtel Nevada. 2002. Closure Report for Corrective Action Unit 392: Spill Sites and Construction Material, Nevada Test Site, Nevada. January. Prepared for U.S. Department of Energy, Nevada Operations Office. DOE/NV -- 778-REV 1. Las Vegas, NV.

Bordelois, B., IT Corporation. 1998. Letter to R. Jackson (ITLV) entitled, "CAU 245

CAS 06-09-01 Sampling Report," 8 August. Las Vegas, NV.

CFR, see Code of Federal Regulations.

Code of Federal Regulations. 2005a. Title 40 CFR, "Protection of the Environment,"

Parts 260-282. Washington, DC: U.S. Government Printing Office.

Code of Federal Regulations. 2005b. Title 40 CFR, "Protection of the Environment," Part 261, "Identification and Listing of Hazardous Waste." Washington, DC: U.S. Government Printing Office.

Code of Federal Regulations. 2005c. Title 40 CFR, "Protection of the Environment," Part 262.34, "Standards Applicable to Generators of Hazardous Waste, Subpart C - Pre-Transport Requirements, Accumulation Time." Washington, DC: U.S. Government Printing Office.

Code of Federal Regulations. 2005d. Title 40 CFR, "Protection of the Environment," Part 761, "PCBs." Washington, DC: U.S. Government Printing Office.

Code of Federal Regulations. 2005e. Title 40 CFR, "Protection of the Environment," Part 763, "Asbestos." Washington, DC: U.S. Government Printing Office.

DOE, see U.S. Department of Energy.

DOE/NV, see U.S. Department of Energy, Nevada Operations Office.

EG\&G/EM, see EG\&G, Energy Measurements Inc.

EPA, see U.S. Environmental Protection Agency.

EG\&G, Energy Measurements Inc. 1985. Aerial photograph 5116-82 of Mercury. Nellis Air Force Base, NV: Remote Sensing Laboratory Photo Library.

EG\&G Rocky Flats. 1991. General Radiochemistry and Routine Analytical Services Protocol (GRASP), Version 2.1. July. Golden, CO.

FFACO, see Federal Facility Agreement and Consent Order.

Federal Facility Agreement and Consent Order. 1996 (as amended). Agreed to by the State of Nevada, the U.S. Department of Energy, and the U.S. Department of Defense. 
Forsgren, F. 1998. Memorandum to R. Jackson entitled, "CAU 397, CAS 23-25-01 Sampling Report," 23 March. Las Vegas, NV.

Harvey, J., Reynolds Electrical \& Engineering Co., Inc. 1991. Area 12, 10 July. Prepared for Unknown.

H\&N, see Holmes and Narver, Inc.

Holmes and Narver, Inc. 1968. Aerial Photograph of Area 6 Well 3 Yard, 9 July. Holmes and Narver, Inc. Various. Las Vegas, NV.

Holmes and Narver, Inc. 1969. Engineering drawing number unknown entitled, "Station U2 AV Post Test Topography," 31 October.

IT, see IT Corporation.

IT Corporation. 1997. Radiological Survey 8/14/97 to 8/26/97, 26 August. Las Vegas, NV.

IT Corporation. 2002. Radiological Land Area Surveys of 24 Corrective Action Sites (CASs) at the Nevada Test Site. Prepared by S. Alderson (IT), 26 August. Las Vegas, NV.

Mellington, S.A., U.S. Department of Energy, Nevada. 1996. Memorandum to P.J. Liebendorfer (NDEP) entitled, "Modification to Corrective Action Unit (CAU) 120 Aboveground Storage Tanks, Nevada Test Site," 20 December. Las Vegas, NV.

Moore, J. 1999. Memorandum to M. Todd (SAIC) entitled, "Background Concentrations for NTS and TTR Soil Samples," 3 February. Las Vegas, NV: IT Corporation.

Murphy, T., Nevada Division of Environmental Protection. 2004. Letter to R.M. Bangerter, Jr. (NNSA/NSO) entitled, “"Review of Industrial Sites Project Document "Guidance for Calculating Industrial Sites Project Remediation Goals for Radionuclides in Soil Using the Residual Radiation (RESRAD) Computer Code,"” 19 November. Las Vegas, NV.

NAC, see Nevada Administrative Code.

NBMG, see Nevada Bureau of Mines and Geology.

NCRP, see National Council on Radiation Protection and Measurements.

NDEP, see Nevada Division of Environmental Protection.

NNSA/NSO, see U.S. Department of Energy, National Nuclear Security Administration Nevada Site Office. 
NNSA/NV, see U.S. Department of Energy, National Nuclear Security Administration Nevada Operations Office.

NRS, see Nevada Revised Statutes.

National Council on Radiation Protection and Measurements. 1999. Recommended Screening Limits for Contaminated Surface Soil and Review of Factors Relevant to Site-Specific Studies/National Council on Radiation Protection and Measurements, NCRP Report No. 129. Bethesda, MD.

Nevada Administrative Code. 1997. NAC 445A.22705, "Contamination of Soil: Evaluation of Site by Owner or Operator." Carson City, NV.

Nevada Administrative Code. 2004a. NAC 444.570 - 444.7499, "Solid Waste Disposal." Carson City, NV.

Nevada Administrative Code. 2004b. NAC 444.850 - 444.8746, "Disposal of Hazardous Waste." Carson City, NV.

Nevada Administrative Code. 2004c. NAC 444.940-444.9555, "Polychlorinated Biphenyls." Carson City, NV.

Nevada Administrative Code. 2004d. NAC 444.965-444.976, "Disposal of Asbestos." Carson City, NV.

Nevada Administrative Code. 2005. NAC 445A.2272, "Contamination of Soil: Establishment of Action Levels." Carson City, NV.

Nevada Bureau of Mines and Geology. 1998. Mineral and Energy Resource Assessment of the Nellis Air Force Range, Open-File Report 98-1. Reno, NV.

Nevada Division of Environmental Protection. 1995. Mutual Consent Agreement Between the State of Nevada and the U.S. Department of Energy for the Storage of Low-Level Land Disposal Restricted Mixed Waste. 7 June. Transmittal from P. Liebendorfer (NDEP) to D. Elle (DOE/NV). Carson City, NV.

Nevada Division of Environmental Protection. 1997a. Class II Solid Waste Disposal Site for Municipal and Industrial Solid Waste, Area 23 of the NTS, Permit SW 1309704. Carson City, NV.

Nevada Division of Environmental Protection. 1997b (as amended in August 2000). Class III Solid Waste Disposal Site for Hydrocarbon Burdened Soils, Area 6 of the NTS, Permit SW 1309702. Carson City, NV.

Nevada Division of Environmental Protection. 1997c (as amended in August 2000). Class III Solid Waste Disposal Site; U10C, Area 9 of the NTS, Permit SW 13097 03. Carson City, NV. 
Nevada Division of Environmental Protection. 1999. State of Nevada Water Pollution Control General Permit, Permit No. GNEV93001. Carson City, NV.

Nevada Revised Statutes. 2005a. NRS 444.440 - 444.620, "Collection and Disposal of Solid Waste." Carson City, NV.

Nevada Revised Statutes. 2005b. NRS 459.400 - 459.600, "Disposal of Hazardous Waste." Carson City, NV.

Nevada Revised Statutes. 2005c. NRS 618.750 - 618.801, “Control of Asbestos.” Carson City, NV.

Paar, J.G., and D.R. Porterfield. 1997. Evaluation of Radiochemical Data Usability. April. $\mathrm{ES} / \mathrm{ER} / \mathrm{MS}-5$.

REECo, see Reynolds Electrical \& Engineering Co., Inc.

Reynolds Electrical \& Engineering Co., Inc. 1956a. Engineering drawing M-U43 entitled, “Dormitories, Structures 501 Thru 508, 513, 514, 515, Sanitary Sewer Layout," 10 January. Las Vegas, NV.

Reynolds Electrical \& Engineering Co., Inc. 1956b. Engineering drawing M-U38 entitled, "Dormitories, Structures 501 Thru 508, 513, 514, 515, Site Grading Plan," 10 January. Las Vegas, NV.

Reynolds Electrical \& Engineering Co., Inc. 1956c. Engineering drawing M-U46 entitled, "Dormitories, Structures 501 Thru 508, 513, 514, 515, Water Distribution Layout," 10 January. Las Vegas, NV.

Reynolds Electrical \& Engineering Co., Inc. 1976a. Engineering drawing NV-35-84-02, drawing 2 of 64, entitled, "Nevada Test Site - Area 6 Control and Data Acquisition Center (CADAC) Demolition Plan,” August. Las Vegas, NV.

Reynolds Electrical \& Engineering Co., Inc. 1976b. Engineering drawing NV-35-84-02, drawing 4 of 64, entitled, "Nevada Test Site - Area 6 Control and Data Acquisition Center (CADAC) Grading and Paving Plan," August. Las Vegas, NV.

Reynolds Electrical and Engineering Co., Inc. 1991a. Nevada Test Site Inventory of Inactive and Abandoned Facilities and Waste Sites Areas 1-4, Volume 1 of 5. DOE/NV/10630-18. Las Vegas, NV.

Reynolds Electrical and Engineering Co., Inc. 1991b. Nevada Test Site Inventory of Inactive and Abandoned Facilities and Waste Sites Areas 5-10, Volume 2 of 5. DOE/NV/10630-18. Las Vegas, NV. 
Reynolds Electrical \& Engineering Co., Inc. 1991c. Nevada Test Site Inventory of Inactive and Abandoned Facilities and Waste Sites Areas 11-15, Volume 3 of 5. DOE/NV/10630-18. Las Vegas, NV.

Reynolds Electrical \& Engineering Co., Inc. 1991d. Nevada Test Site Inventory of Inactive and Abandoned Facilities and Waste Sites Areas 22-30, Volume 5 of 5. DOE/NV/10630-18. Las Vegas, NV.

Reynolds Electrical and Engineering Co., Inc. 1992. Section L Potential Solid Waste Management Units, RCRA Part B Application, Nevada Test Site, July. Las Vegas, NV.

Shaw, see Shaw Environmental and Infrastructure, Inc.

SNJV, see Stoller-Navarro Joint Venture.

Shaw Environmental and Infrastructure, Inc. 2002. Results of Geophysical Survey Selected FFACO Sites Nevada Test Site. 27 September. Las Vegas, NV.

Stoller-Navarro Joint Venture. 2005. Industrial Sites Preliminary Field Activity Daily Logs and Field Forms for site visits conducted for CAU 538. Las Vegas, NV: SNJV Central Files

Sygitowicz, L.S. Bechtel Nevada. 1998. Letter to K.A. Hoar (DOE/NV) entitled, "Transmittal of 30 Day Report for Nevada Division of Emergency Management (NDEM) Case Number 980624-2903 - Underground Storage Tank 6-CP-9," 15 July. Las Vegas, NV.

USC, see United States Code.

United States Code. 1976. 15 USC 2601 et seq., “Toxic Substances Control Act," Enacted by Public Law No. 94-469, as amended. Washington, DC: U.S. Government Printing Office.

U.S. Department of Energy. 1993. DOE Order 5440.5, Change 2, Radiation Protection of the Public and the Environment. Washington, DC: U.S. Government Printing Office.

U.S. Department of Energy. 1997. The Procedures Manual of the Environmental Measurements Laboratory Procedures Manual, HASL-300, 28th Ed., Vol. I. New York, NY.

U.S. Department of Energy. 1999. Aerial photograph 9997-21 showing Area 3 Camp, 14 May. Nellis Air Force Base, NV: Remote Sensing Laboratory Photo Library.

U.S. Department of Energy. 2000. Nevada Test Site, NV Digital Orthophoto Quadrangles showing approximate location of CAS 06-44-06, 28 August. Las Vegas, NV. 
U.S. Department of Energy, National Nuclear Security Administration Nevada Operations Office. 2002a. "Fluid Management Plan for the Underground Test Area Project," DOE/NV--370. Rev. 3. In Underground Test Area Waste Management Plan, Rev. 2. Las Vegas, NV.

U.S. Department of Energy, National Nuclear Security Administration Nevada Operations Office. 2002b. Industrial Sites Quality Assurance Project Plan, Nevada Test Site, Nevada, Rev. 3, DOE/NV--372. Las Vegas, NV.

U.S. Department of Energy, National Nuclear Security Administration Nevada Operations Office. 2002c. Nevada Test Site Orthophoto Site Atlas, DOE/NV/11718-604. Aerial photos acquired Summer 1998. Prepared by Bechtel Nevada. Las Vegas, NV.

U.S. Department of Energy, National Nuclear Security Administration Nevada Site Office. 2005a. Nevada Test Site Waste Acceptance Criteria (NTSWAC), Rev. 6. Las Vegas, NV.

U.S. Department of Energy, National Nuclear Security Administration Nevada Site Office. $2005 \mathrm{~b}$. NV/YMP Radiological Control Manual, DOE/NV--11718-079, Rev. 5. Las Vegas, NV.

U.S. Department of Energy, National Nuclear Security Administration Nevada Site Office. 2006a. Facilities Information Management System (FIMS) database, as accessed at http://bnapp3.nv.doe.gov/06nts/TEXT/Hazards/LURCPS.htm on 9 January. Las Vegas, NV.

U.S. Department of Energy, National Nuclear Security Administration Nevada Site Office. 2006b. Industrial Sites Project Establishment of Final Action Levels, DOE/NV--1107. February. Las Vegas, NV.

U.S. Department of Energy, Nevada Operations Office. 1996. Final Environmental Impact Statement for the Nevada Test Site and Off-Site Locations in the State of Nevada, DOE/EIS 0243. Las Vegas, NV.

U.S. Department of Energy, Nevada Operations Office. 1998. "Closure Report for Underground Storage Tank Release Sites at the Nevada Test Site: UST6-619-3 (NDEM \# 98-0909-3054), UST 6-CP-40 (NDEM \#98-0413-2764) and UST 6-CP-9 (NDEM \#98-0624-2903)." Prepared by Bechtel Nevada Environmental Restoration. Las Vegas, NV.

U.S. Environmental Protection Agency. 1980. Prescribed Procedures for Measurement of Radioactivity in Drinking Water, EPA 600/4-80-032 (NTIS/PB80-224744; CD ROM; NEPIS/http://www.epa.gov/cincl). Prepared by H.L. Krieger and E.K. Whittaker. Cincinnati, $\mathrm{OH}$.

U.S. Environmental Protection Agency. 1988a. Contract Laboratory Program Statement of Work for Inorganic Analysis, SOW No. 788, EPA/540/R-94/093. Washington, DC.

U.S. Environmental Protection Agency. 1988b. Contract Laboratory Program Statement of Work for Organic Analysis, SOW No. 2/88, EPA/540/R-94//096. Washington, DC. 
U.S. Environmental Protection Agency. 1991. Contract Laboratory Program Statement of Work for Organic Analysis, OLMO 1.8, EPA/540/R-94/078. Washington, DC.

U.S. Environmental Protection Agency. 1994a. Contract Laboratory Program Statement of Work for Inorganic Analysis, ILMO 3.0, EPA/540/R-94/076. Washington, DC.

U.S. Environmental Protection Agency. 1994b. Contract Laboratory Program Statement of Work for Organic Analysis, OLMO 3.1, EPA/540/R-94/073. Washington, DC.

U.S. Environmental Protection Agency. 1995. Contract Laboratory Program Statement of Work for Inorganic Analysis, ILMO 4.0, EPA/540/R-95/121. Washington, DC.

U.S. Environmental Protection Agency. 1996. Test Methods for Evaluating Solid Waste, Physical/Chemical Methods, SW-846, $3^{\text {rd }}$ Edition (which includes updates to 1986, 1992, and 1994 revisions), CD-ROM PB97-501928GEI. Washington, DC.

U.S. Environmental Protection Agency. 2000. Data Quality Objectives Process for Hazardous Waste Site Investigations. EPA QA/G-4HW. Washington, DC.

U.S. Environmental Protection Agency. 2001. Integrated Risk Information System (IRIS) Database, as accessed at http://www.epa.gov/index.html on 27 October 2005.

U.S. Environmental Protection Agency. 2002. Guidance for Quality Assurance Project Plans, EPA QA/G5. Washington, DC.

U.S. Environmental Protection Agency. 2004. Region 9 Preliminary Remediation Goals (PRGs). As accessed at http://www.epa.gov/region09/waste/sfund/prg/index.htm on 25 May 2005. Prepared by S.J. Smucker. San Francisco, CA.

Weil, S.R., Bechtel Nevada. 1996. Letter to J.A. Blodgett (DOE/NV) entitled, "Prospective Sites For Addition to Appendix 2 of the Federal Facilities Agreement and Consent Order (FFACO)," 17 January. Las Vegas, NV. 


\section{Appendix A \\ Project Organization}




\section{A.1.0 Project Organization}

The NNSA/NSO Environmental Restoration Project, Acting Federal Industrial Sites Sub-Project Director is Sabine Curtis, and she can be contacted at (702) 295-0542. The NNSA/NSO

Environmental Restoration Project, Industrial Site Sub-Project Task Manager is Kevin Cabble, and he can be contacted at (702) 295-5000.

The identification of the project Health and Safety Officer and the QA Officer can be found in the appropriate plan. However, personnel are subject to change and it is suggested that the appropriate DOE Federal Sub-Project Director be contacted for further information. The SNJV Task Manager will be identified in the FFACO Monthly Activity Report before the start of field activities. 


\section{Appendix B \\ Data Quality Objective Process}




\section{B.1.0 Introduction}

The DQO process described in this appendix is a seven-step strategic planning method based on the scientific method used to plan data collection activities and define performance criteria for the CAU 538, Spill Sites, field investigation. The DQOs are designed to ensure that the data collected will provide sufficient and reliable information to determine the appropriate corrective actions, verify the adequacy of existing information, provide sufficient data to implement the corrective actions, and verify that closure was achieved.

The seven steps of the DQO process presented in Sections B.2.0 through B.8.0 were developed according to the EPA Guidance for the Data Quality Objectives Process (EPA, 2000b) and EPA Guidance for Quality Assurance Project Plans (EPA, 2002). The DQO process presented herein is based on the EPA Quality System Document for DQOs entitled, Data Quality Objectives Process for Hazardous Waste Site Investigations (EPA, 2000a) and the CAS-specific information presented in Section B.2.0.

The DQO process presents a judgmental sampling approach and using the following procedures provides:

- Scientific basis for making inferences about a site (or portion of a site) based on site history, environmental data, and/or process knowledge.

- Basis for defining decision performance criteria and assessing the achieved decision quality of the data collection approach.

- Basis for demonstrating an acceptable level of confidence in the sampling approach to generate the appropriate quantity and quality of data and information necessary to minimize the potential for making decision errors.

- Criteria for knowing when site investigators have sufficient information to support decisions. 


\section{B.2.0 Step 1 - State the Problem}

This initial step of the seven-step DQO process for CAU 538 identifies the planning team participants and describes the problem that must be resolved to close CAU 538. Corrective Action Unit 538 is being investigated because some data gaps exist concerning the nature and extent of potential contamination. These data are necessary to evaluate and confirm closure alternatives for the individual CASs.

As a result of activities associated with each of the CAU $538 \mathrm{CASs}$, potentially hazardous and/or radioactive constituents may be present at concentrations that could potentially pose a threat to human health and the environment.

The problem statement for the CAU 538 CASs is: "Existing information on the nature and extent of potential contamination is insufficient to evaluate and confirm closure of the individual CASs in CAU 538."

\section{B.2.1 Data Quality Objective Planning Team Members}

The investigation will be based on the DQOs presented in this appendix as developed with concurrence from NDEP and NNSA/NSO representatives. The DQO planning team consists of representatives from NDEP, NNSA/NSO, Stoller-Navarro Joint Venture (SNJV), and BN. The primary decision makers include NDEP and NNSA/NSO representatives. Decision makers will receive notifications as work progresses and when decision points are reached within the SAFER process. Table B.2-1 lists the titles of representatives from each organization in attendance for the DQO presentation held on December 15, 2005.

\section{B.2.2 Conceptual Site Model}

The CSM describes the most probable scenario for current conditions at each CAS and defines the assumptions that are the basis for identifying appropriate CAS-specific sampling strategies and data collection methods. The CSM assesses how contaminants could reach receptors both in the present and future by addressing the nature and extent of the contaminant, transport mechanisms and 


\section{Table B.2-1 \\ Planning Meeting Participants for CAU 538 DQO \\ December 15, 2005}

\begin{tabular}{|c|c|}
\hline Affiliation & Department/Project Team Function \\
\hline NDEP & NDEP Representative \\
\hline NNSA/NSO & Environmental Restoration Project Federal Industrial Sites Sub-Project Task Manager \\
\hline BN & Environmental Restoration Deputy Project Manager \\
\hline $\mathrm{BN}$ & Environmental Restoration Field Support Manager \\
\hline \multicolumn{2}{|r|}{ Project Team Members } \\
\hline SNJV & Industrial Sites Project Manager \\
\hline SNJV & Industrial Sites Technical Coordinator \\
\hline SNJV & Industrial Sites (CAU 538) Task Lead \\
\hline SNJV & Industrial Sites Preliminary Assessment \\
\hline SNJV & Federal Facility Agreement and Consent Order Representative \\
\hline SNJV & Quality Assurance Representative \\
\hline SNJV & Analytical Services Chemical Data Validator \\
\hline SNJV & Analytical Services Radiological Data Validator \\
\hline SNJV & Health and Safety Group Representative \\
\hline SNJV & Environmental Compliance and Waste Management Representative \\
\hline SNJV & Radiation Services Health Physicist \\
\hline
\end{tabular}

$\mathrm{BN}=$ Bechtel Nevada

NDEP = Nevada Division of Environmental Protection

NNSA/NSO = U.S. Department of Energy, National Security Administration Nevada Site Office

SNJV = Stoller-Navarro Joint Venture

pathways, potential receptors, and potential exposures to receptors. An accurate CSM is important, as it serves as the basis for subsequent inputs and decisions throughout the DQO process.

The CSM was developed for CAU 538 using elements evaluated to include:

- Historical information and process knowledge including information from similar sites.

- Potential contaminant releases, including media potentially affected.

- Release mechanisms (the conditions associated with the release). 
- Potential contaminant source characteristics and contaminant-specific properties.

- Site characteristics including physical, topographical, and meteorological information.

- Transport mechanisms and migration pathways that describe the potential for migration and where the contamination may be transported.

- Exposure routes, pathways, and locations where individuals or populations may come in contact with a COC released from a CAS.

If additional elements are identified during the investigation that are outside the scope of the CSM, the situation will be reviewed and a recommendation will be made on how to proceed. In such cases, NDEP and NNSA/NSO will be notified and given the opportunity to comment or concur with the recommendation.

Figure B.2-1 identifies the exposure routes and pathways from the source of release to potential receptors. Figure B.2-2 illustrates the CSM for the releases included in this CAU, and Table B.2-2 provides a summary of the information for each CSM elements.

\section{B.2.2.1 Contaminant Release}

Contamination, if present, is expected to be contiguous to the release points, and concentrations are expected to decrease with horizontal and vertical distance from the source. Based on the depth to groundwater, which varies for each CAS, groundwater contamination is not considered a likely scenario. Surface migration may occur as the result of the release or as runoff of precipitation, and is a biasing factor considered in the selection of sampling points.

The most likely locations of the contamination and releases to the environment are the soils directly below or adjacent to the CSM surface and shallow subsurface components. The CSM accounts for potential releases resulting from migration away from the sites of releases that are present at the ground surface.

Because of the expected limited mobility, the affected media is typically the surface and shallow subsurface soil. The native soil interface below and adjacent to the release point is the most likely location for soil contamination. Any contaminants from CASs, regardless of physical or chemical characteristics, are expected to be in soil adjacent to the source or release point. 


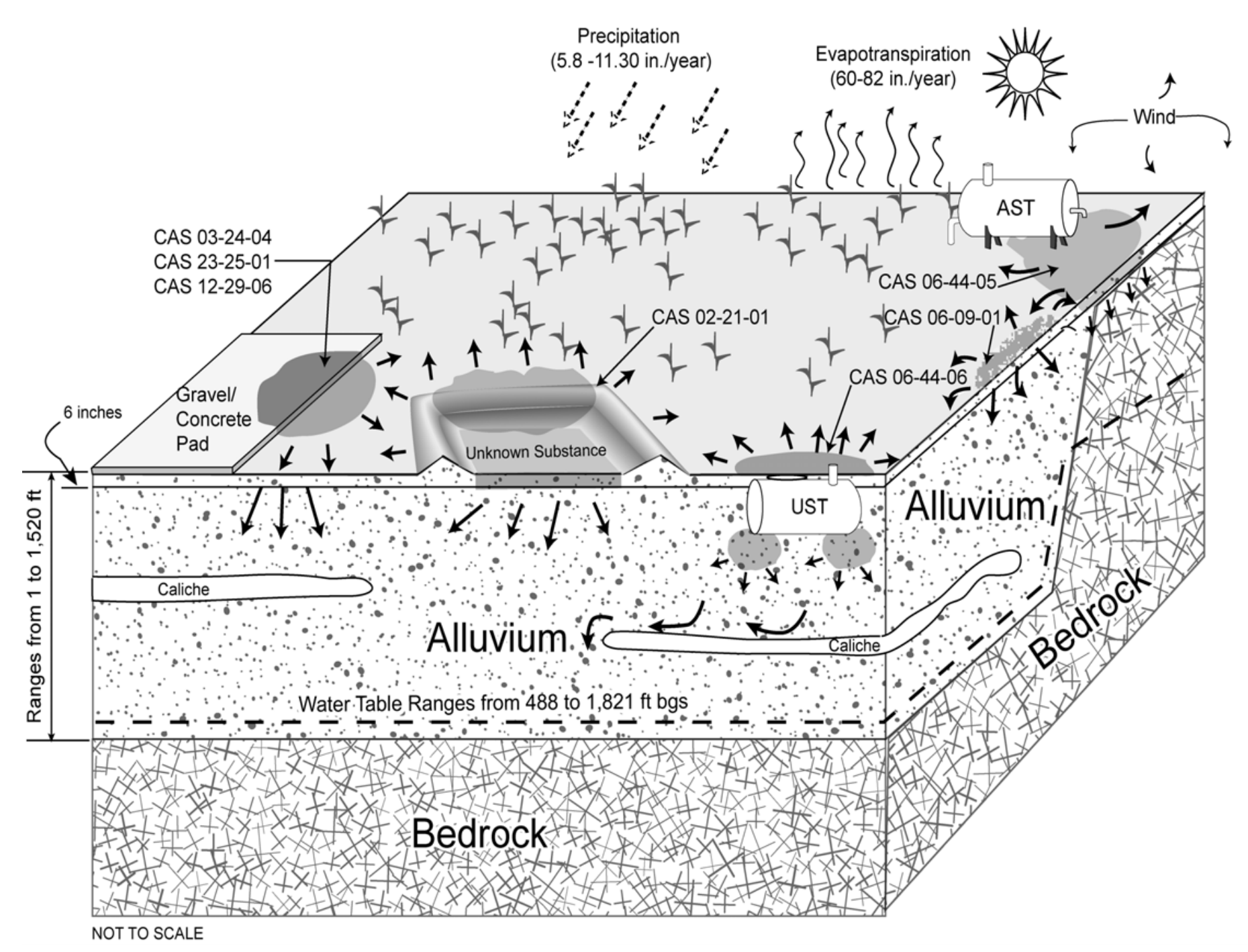

Figure B.2-1

Conceptual Site Model for CAU 538 Corrective Action Sites 


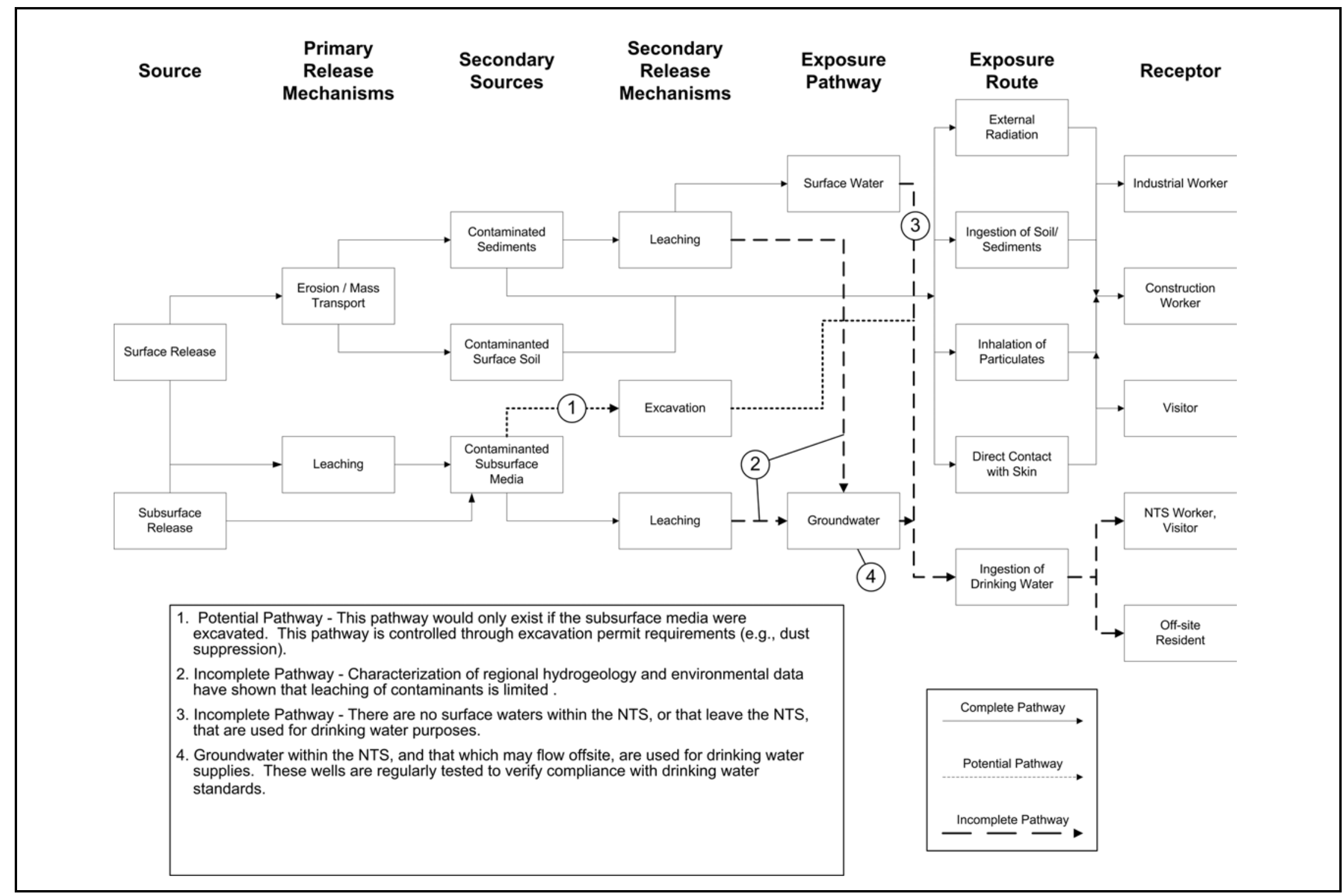

Figure B.2-2

Conceptual Site Model Diagram for CAU 538 Corrective Action Sites

\section{Uncontrolled When Printed}


Table B.2-2

Conceptual Site Model

Description of Elements for Each $\mathrm{CAS}^{\mathrm{a}}$ in CAU 538

(Page 1 of 2)

\begin{tabular}{|c|c|c|c|c|c|c|}
\hline CAS Identifier & $02-21-01$ & $03-25-04$ & $06-44-05$ & 06-44-06 & $12-29-06$ & $23-25-01$ \\
\hline CAS Description & Epoxy Tar Pit & Hydrocarbon Stain & $\begin{array}{l}\text { Diesel Spill From } \\
\text { Tank \#38061 }\end{array}$ & $\begin{array}{l}\text { Spill Site with } \\
\text { Hydrocarbons }\end{array}$ & Spill Site & Oil Stains \\
\hline Site Status & \multicolumn{6}{|c|}{ Sites are inactive and/or abandoned } \\
\hline $\begin{array}{l}\text { Sources of Potential } \\
\text { Contamination }\end{array}$ & $\begin{array}{l}\text { Unknown, possibly } \\
\text { from activities at 2ao } \\
\text { Crater (i.e., stemming } \\
\text { operations, use of } \\
\text { drilling mud) }\end{array}$ & $\begin{array}{l}\text { Leaky and/or overfill } \\
\text { of air compressor } \\
\text { fuel tank }\end{array}$ & $\begin{array}{c}\text { Leaky and/or } \\
\text { overfill of } 1,000-\text { gal } \\
\text { AST with diesel } \\
\text { fuel }\end{array}$ & $\begin{array}{l}\text { Leaky and/or overfill } \\
\text { of } 5,000 \text {-gal UST } \\
\text { with diesel fuel }\end{array}$ & $\begin{array}{l}\text { Runoff from } \\
\text { potentially } \\
\text { contaminated } \\
\text { building pad, } \\
\text { and/or direct } \\
\text { release to soil }\end{array}$ & $\begin{array}{l}\text { Leaky and/or } \\
\text { overfill of AST, } \\
\text { and/or runoff } \\
\text { from potentially } \\
\text { contaminated } \\
\text { building pad }\end{array}$ \\
\hline $\begin{array}{l}\text { Location of } \\
\text { Contamination/ } \\
\text { Release Point }\end{array}$ & $\begin{array}{l}\text { Surface soil beneath } \\
\text { unknown substance }\end{array}$ & $\begin{array}{l}\text { Gravel pad and soil } \\
\text { interface }\end{array}$ & $\begin{array}{l}\text { Surface soil } \\
\text { beneath AST }\end{array}$ & $\begin{array}{c}\text { Surface soil } \\
\text { subsurface soil } \\
\text { surrounding UST }\end{array}$ & $\begin{array}{l}\text { Surface soil } \\
\text { adjacent to } \\
\text { building } \\
\text { foundation }\end{array}$ & $\begin{array}{l}\text { Surface soil } \\
\text { adjacent to } \\
\text { building pad } \\
\text { and beneath } \\
\text { AST }\end{array}$ \\
\hline Amount Released & Unknown & Unknown & Unknown & $\begin{array}{l}\text { Greater than } 25 \text { gal } \\
\text { (Sygitowicz, 1998) }\end{array}$ & Unknown & Unknown \\
\hline Affected Media & $\begin{array}{l}\text { Surface and possibly } \\
\text { shallow subsurface soil }\end{array}$ & $\begin{array}{l}\text { Surface and shallow } \\
\text { subsurface soil }\end{array}$ & $\begin{array}{l}\text { Surface and } \\
\text { possibly } \\
\text { subsurface soil }\end{array}$ & $\begin{array}{l}\text { Surface and } \\
\text { subsurface soil }\end{array}$ & $\begin{array}{l}\text { Surface and } \\
\text { shallow } \\
\text { subsurface soil }\end{array}$ & $\begin{array}{l}\text { Surface and } \\
\text { shallow } \\
\text { subsurface and } \\
\text { potentially } \\
\text { shallow } \\
\text { subsurface soil }\end{array}$ \\
\hline Potential Contaminants & \multicolumn{6}{|c|}{ VOCs; SVOCs; RCRA Metals; TPH; PCBs; pesticides (within $10 \mathrm{ft}$ of building pads); and gamma-emitters (excluding CAS 23-25-01) } \\
\hline
\end{tabular}


Table B.2-2

\section{Conceptual Site Model}

\section{Description of Elements for Each CAS $^{\mathrm{a}}$ in CAU 538}

(Page 2 of 2)

\begin{tabular}{|c|c|c|c|c|c|c|}
\hline CAS Identifier & 02-21-01 & $03-25-04$ & 06-44-05 & $06-44-06$ & $12-29-06$ & 23-25-01 \\
\hline CAS Description & Epoxy Tar Pit & Hydrocarbon Stain & $\begin{array}{c}\text { Diesel Spill From } \\
\text { Tank \#38061 }\end{array}$ & $\begin{array}{l}\text { Spill Site with } \\
\text { Hydrocarbons }\end{array}$ & Spill Site & Oil Stains \\
\hline Transport Mechanisms & \multicolumn{6}{|c|}{$\begin{array}{l}\text { Percolation of precipitation through subsurface media serves as the major driving force for migration of contaminants. However, } \\
\text { because the arid environment of the NTS, percolation of precipitation is very small and migration of contaminants has been shown to } \\
\text { be limited (USGS, 1995). Evaporation potentials significantly exceed available soil moisture from precipitation (i.e., } 5.8 \text { to } \\
11.30 \text { in./yr) (ARL/SORD, 2005). Surface water runoff may have transported of some contaminants laterally. Liquid periodically } \\
\text { released to the subsurface from the former UST 6-CP-9 over time at CAS 06-44-06 and from the AST at 06-44-05 may also have } \\
\text { provided a hydraulic driver for vertical migration of contaminants. }\end{array}$} \\
\hline Migration Pathways & \multicolumn{6}{|c|}{$\begin{array}{l}\text { No other migration pathway anticipated other than soil where it is expected that lateral migration in the surface soil ( } 0 \text { to } 0.5 \mathrm{ft} \text { bgs) } \\
\text { and shallow subsurface }(0.5 \text { to } 5 \mathrm{ft} \text { bgs) will dominate over the vertical migration in the subsurface soil (greater } 5 \mathrm{ft} \text { bgs). }\end{array}$} \\
\hline $\begin{array}{l}\text { Lateral and Vertical } \\
\text { Extent of Contamination }\end{array}$ & \multicolumn{6}{|c|}{$\begin{array}{l}\text { Contamination, if present, is expected to be contiguous to the release points. Concentrations are expected to decrease with distance } \\
\text { and depth from the source. Groundwater contamination is not expected. Depth to groundwater varies from } 488 \mathrm{ft} \text { bgs to } \\
1,821 \mathrm{ft} \text { bgs. Surface migration may occur as a result of runoff. }\end{array}$} \\
\hline Future Land Use Zones ${ }^{b}$ & $\begin{array}{l}\text { Nuclear and High } \\
\text { Explosive Tests }\end{array}$ & $\begin{array}{l}\text { Nuclear and High } \\
\text { Explosive Tests }\end{array}$ & Reserved & Defense Industrial & $\begin{array}{l}\text { Nuclear and High } \\
\text { Explosive Tests }\end{array}$ & Reserved \\
\hline \multirow[t]{2}{*}{ Exposure Scenario $^{c}$} & Occasional Use Area & $\begin{array}{l}\text { Occasional Use } \\
\quad \text { Area }\end{array}$ & $\begin{array}{l}\text { Occasional Use } \\
\quad \text { Area }\end{array}$ & Industrial Use Area & $\begin{array}{c}\text { Occasional Use } \\
\text { Area }\end{array}$ & $\begin{array}{c}\text { Industrial Use } \\
\text { Area }\end{array}$ \\
\hline & \multicolumn{6}{|c|}{$\begin{array}{l}\text { The potential for contamination exposure is limited to NTS personnel (e.g., industrial and construction workers), personnel training } \\
\text { (e.g., emergency response training, military exercises), and visitors. These human receptors may be exposed to COPCs through } \\
\text { oral ingestion, inhalation, external exposure to radiation, dermal contact (absorption) of soil and/or debris due to inadvertent } \\
\text { disturbance of these materials. }\end{array}$} \\
\hline
\end{tabular}

aNo samples are initially planned at CAS 06-09-01; therefore, it is not included in this table.

${ }^{b} \mathrm{DOE} / \mathrm{NV}, 1996$

${ }^{\mathrm{C} D O E} / \mathrm{NV}, 2006$

AST $=$ Aboveground storage tanks

bgs $=$ Below ground surface

$\mathrm{COPC}=$ Contaminant of potential concern

$\mathrm{ft}=$ Foot gal $=$ Gallon

in./yr = Inch per year

NTS $=$ Nevada Test Site

$\mathrm{PCB}=$ Polychlorinated biphenyl
RCRA = Resource Conservation and Recovery Act

SVOC = Semivolatile organic compound

$\mathrm{TPH}=$ Total petroleum hydrocarbons

UST $=$ Underground storage tank
VOC $=$ Volatile organic compound

\section{Uncontrolled When Printed}


The COPCs, if present, are associated with the (1) release of petroleum hydrocarbon products from leaking machinery, tanks, and vehicles; (2) release of hydrocarbon products during mechanical operations; (3) overfilling of tanks (i.e., CASs 06-44-05 and 06-44-06) or vehicles (i.e., CAS 23-25-01) during refueling activities; and (4) release of hydrocarbon compounds and potentially other hazardous constituents from onsite storage of hazardous materials. Surface and shallow subsurface soils are the affected or suspected affected media within each CAS. The volume of each release at each location is unknown. At CAS 06-44-06, the subsurface soil associated with the former UST 6-CP-9 is the affected media and the volume of diesel fuel released to the site is reported to be greater than 25 gal.

Existing site-specific data, which are an element of this CSM used to identify COPCs and target analytes for each CAS, are discussed in Section 2.0.

\section{B.2.2.2 Potential Contaminants}

The COPCs listed in Table B.2-3 are intended to encompass all of the contaminants that could potentially be present at each CAS. The COPCs are applicable to Decision I environmental samples from each of the CASs. These contaminants were identified during the planning process through the review of site histories, process knowledge, personnel interviews, previous investigation efforts (where available), and inferred activities associated with the CASs. Because complete information regarding activities performed at the CAU 538 sites is not available, contaminants detected at other similar or other NTS sites were included in the contaminant lists to reduce the uncertainty.

During this review, selected COPCs were identified as targeted analytes at specific CASs. Targeted analytes are those COPCs for which evidence in the available site histories and process knowledge information suggest that these analytes are present or are reasonably suspected to be present at a given CAS. The targeted analytes are required to meet a more stringent completeness criteria (see Section 7.2.5) than other COPCs, thus providing greater protection against a decision error (see Section B.7.0). The COPCs and targeted analytes identified for each CAS are listed in Table B.2-3. 
Table B.2-3

Contaminants of Potential Concern and Targeted Analytes for CAU 538 Corrective Action Sites ${ }^{a}$

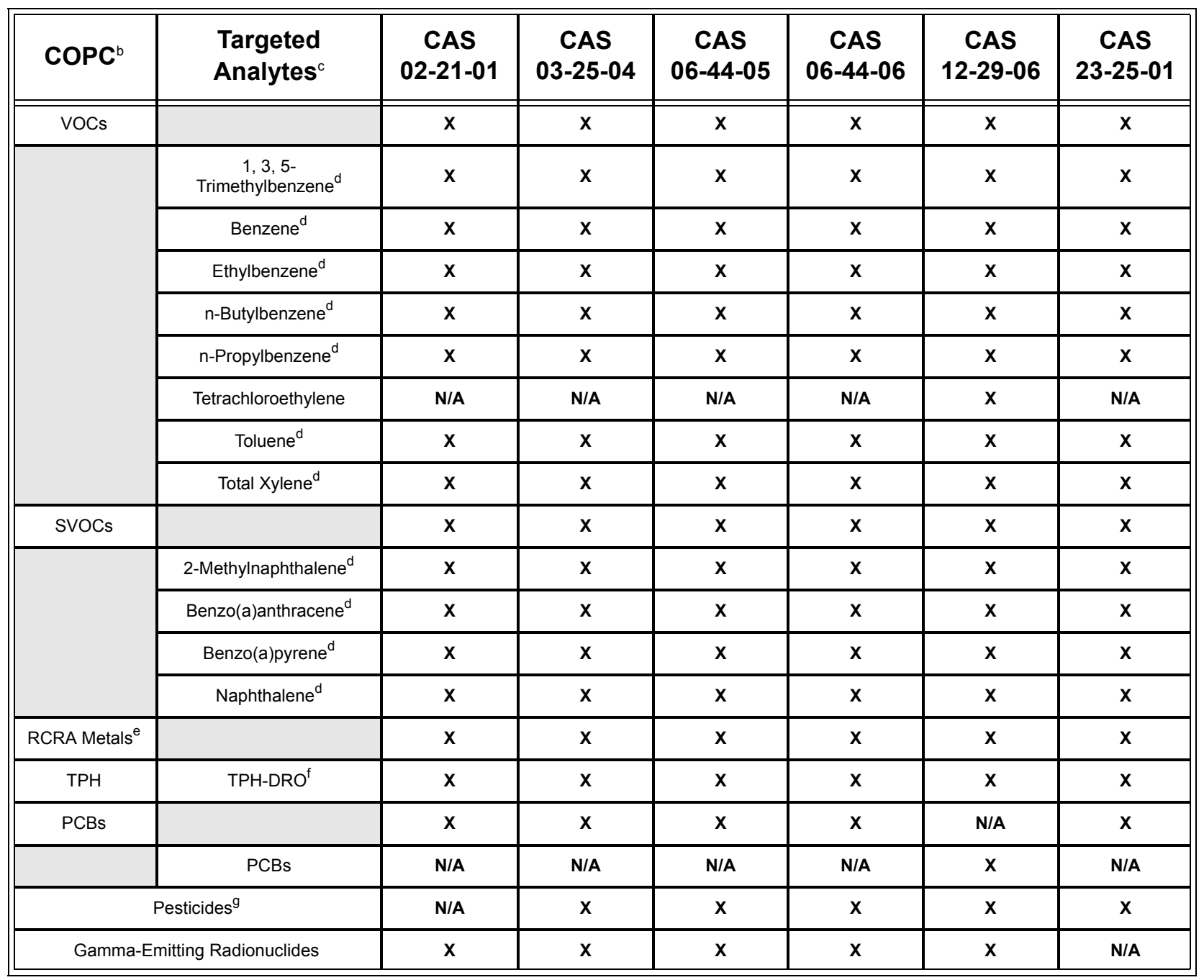

${ }^{a}$ No samples are initially planned at CAS 06-09-01; therefore, it is not included in this table.

${ }^{\mathrm{b}} \mathrm{COPCs}$ are contaminants that could be potentially present.

${ }^{\mathrm{c}}$ Targeted analytes are present or are reasonably suspected to be present and are required to meet a completeness criteria of 100 percent.

dWill only be considered a targeted analyte for samples that exceed the PALs for TPH (NNSA/NSO, 2006).

${ }^{\text {e}}$ Beryllium will be requested with RCRA metals for administrative purposes such as obtaining background beryllium levels.

${ }^{\mathrm{f}} \mathrm{TPH}$ or the hazardous constituents of TPH.

${ }^{9}$ Pesticide analysis will only be conducted on soil samples collected within $10 \mathrm{ft}$ of a building foundation.

$\mathrm{DRO}=$ Diesel-range organics

$\mathrm{ft}=$ Foot

$\mathrm{N} / \mathrm{A}=$ Not applicable

$\mathrm{PAL}=$ Preliminary action level

$\mathrm{PCB}=$ Polychlorinated biphenyl

RCRA = Resource Conservation and Recovery Act

SVOC $=$ Semivolatile organic compound

$\mathrm{TPH}=$ Total petroleum hydrocarbons

$\mathrm{VOC}=$ Volatile organic compound 


\section{B.2.2.3 Contaminant Characteristic}

Typically, contaminants with low solubility, high density, and/or high adsorption capabilities can be expected to be found relatively close to release points. Contaminants with small particle size, high solubility, low density, and/or low affinity for soil can be expected to be found further from release points, or in low areas where settling may occur and evaporation would concentrate dissolved constituents. The COPCs can impact various media (air, soil, water) dependent on the transport mechanism. Volatile COPCs may impact the air, and COPCs contained in a liquid media or are "dusts" dissolved by rainwater may infiltrate the subsoil and potentially impact groundwater. Infiltration of any COPC, beyond shallow soil, is not a concern at these sites as discussed in the groundwater impacts section.

\section{B.2.2.4 Site Characteristics}

Site characteristics are defined by the interaction of physical, topographical, and meteorological properties. Physical properties include permeability, porosity, hydraulic conductivity, degree of saturation, sorting, chemical composition, and organic content. Topographical and meteorological properties include slope stability, precipitation frequency and amounts, precipitation runoff pathways, drainage channels and ephemeral streams, and evapotranspiration potential.

The NTS lies in the southern part of the Great Basin section of the Basin and Range physiographic province (USGS, 1996). The topography of this province consists of numerous north-south trending, linear mountain ranges separated by broad, flat-floored and gently-sloped valleys.

The general geology of the NTS consists primarily of the following geologic units. The oldest units are complexly folded and faulted Paleozoic units composed mainly of carbonate rocks (limestone and dolomite) separated by a middle section of siliciclastic rocks (shale and quartzite). Tertiary-age volcanic tuffs and lavas overlay the Paleozoic units in many places. The valleys are covered with Tertiary and Quaternary-age alluvial and colluvial deposits that have been eroded from the surrounding mountain ranges (ERDA, 1977).

The structural geology of the NTS is complex. Thousands of normal faults lie within the area and are responsible for the main characteristics of the Basin and Range topography (Winograd and Thordarson, 1975). 
Along with normal faults, strike-slip faults and shear zones cut and offset thrust faults in several places on the NTS. The complexity of the structural geology may influence the regional movement of groundwater (LLNL, 1982; Winograd and Thordarson, 1975).

Numerous underground tests conducted in Yucca Flat are known to have induced fractures not related to the natural tectonic activities. These fractures developed along trends parallel to the master joint sets in rocks adjacent to the test location. The subsurface tests have had a significant effect on fracture patterns (SNL, 1982). Corrective Action Site 02-21-01 is located within the vicinity of many emplacement holes as shown on the aerial photograph provided in Figure 2-1.

The static water levels at the CAU 538 CASs range between $488 \mathrm{ft}$ and 1,821 ft bgs. The CAU 538 CASs are located within the Ash Meadows subbasin that lies within the Death Valley groundwater flow system. Groundwater is not expected to be impacted from potential releases from CAU 538 because the arid environment of the NTS results in nominal infiltration of precipitation and limited migration of contaminants (USGS, 1995). Evapotranspiration potentials at the NTS range between 60 and 82 inches per year (in./yr), significantly exceeding the average annual precipitation across the NTS. The average annual precipitation at the CAU 538 CAS range between 5.80 and 11.30 in./yr (ARL/SORD, 2005).

Site-specific characteristics of each CAS are provided below:

- Depth to groundwater at CAS 02-21-01 lies between approximately $559 \mathrm{ft}$ bgs (Dynamic Graphics, 2002) and 1,821.3 ft bgs (Well U-2gg) (USGS and DOE, 2005) and discharges approximately 40 miles into the Ash Meadows springs (USGS, 1996). This CAS is located between the U-2ao and U-2br emplacement holes where the thickness of the alluvium ranges between 1,083 and 1,280 ft (Ray, 1971; Howard, 1977) and is made up of poorly sorted sands and silts with calcareous cementation (BN, 1999b). The alluvium is underlain by volcanic layers of tuffs, tuffaceous sandstones, and volcanic zeolitized tuff (Ray, 1971 and BN, 1999b). The average annual precipitation recorded at the Buster Jangle Wye (BJY) raingauge station is 6.40 in. (ARL/SORD, 2005).

- Depth to groundwater at CAS 03-25-04 lies between approximately $488 \mathrm{ft}$ bgs (Dynamic Graphics, 2002) and $792 \mathrm{ft}$ bgs (USGS, 1961; Wuellner, 1994; USGS and DOE, 2005). The thickness of the alluvium is estimated to be approximately $813 \mathrm{ft}$ (Dynamic Graphics, 2002). The average annual precipitation recorded at the BJY raingauge station is 6.40 in. (ARL/SORD, 2005). 
- Depth to groundwater at 06-09-01 is between approximately $542 \mathrm{ft}$ bgs (Dynamic Graphics, 2002) and 1,533 ft bgs (DOE, 1996). The thickness of the alluvium ranges between $505 \mathrm{ft}$ (Dynamics Graphics, 2002) and 1,520 ft (DOE/NV, 1996). The average annual precipitation recorded at the UCC (Yucca Dry Lake) raingauge station is 6.70 in. (ARL/SORD, 2005).

- Depth to groundwater at 06-44-05 lies between approximately $733 \mathrm{ft}$ bgs (Dynamic Graphics, 2002) and 1,784 ft bgs (USGS and DOE, 2005). There is nominal alluvium because the site is situated atop bedrock. The average annual precipitation recorded at the UCC (Yucca Dry Lake) raingauge station is 6.70 in. (ARL/SORD, 2005).

- Depth to groundwater at CAS 06-44-06 lies between approximately $721 \mathrm{ft}$ bgs (Dynamic Graphics, 2002) and 1,784 ft bgs (USGS and DOE, 2005). The average thickness of alluvium is estimated at approximately $188 \mathrm{ft}$ (Dynamic Graphics, 2002) and is described as tightly packed, sandy silt that is very dense and contains cobbles and boulders (Cowser, 1998; DOE/NV, 1998) with thin zones of caliche (Cowser, 1998). The presence of bedrock between 19 and $21 \mathrm{ft}$ bgs was reported on a borehole $\log (\mathrm{DOE} / \mathrm{NV}, 1998)$. The site is located within the CP facility, which is located within the southern portion of a large, closed drainage basin. Yucca Lake is the collection point of the runoff generated in this basin and is drained by an arroyo system that carries a high volume of water during the high-intensity, low-duration storms that are common to the region (Holmes \& Narver, Inc. 1981). The average annual precipitation recorded at the A06 South (Area 6) raingauge station is $5.80 \mathrm{in}$. (ARL/SORD, 2005).

- Depth to groundwater at CAS 12-29-06 is approximately 1,526 ft bgs (USGS and DOE, 2005). The surface water at this site drains into Tongue Wash, which eventually flows into other ephemeral channels draining east into the Yucca Flat closed hydrographic basin (DRI, 1996). The average annual precipitation recorded at the ETu (E-Tunnel) raingauge station is 11.30 in. (ARL/SORD, 2005).

- Depth to groundwater at CAS 23-25-01 is $745 \mathrm{ft}$ bgs (Dynamic Graphics, 2002). The groundwater flows southwestwardly through carbonate rocks and discharges into the Ash Meadows springs located approximately 25 miles southwest of Mercury (ERDA, 1977). The thickness of alluvium is approximately $745 \mathrm{ft}$ and is underlain by an additional $4 \mathrm{ft}$ of thin, patchy volcanics before reaching the lower carbonate unit at approximately $750 \mathrm{ft}$ bgs (Dynamic Graphics, 2002). The average annual precipitation recorded at the MER (Mercury) raingauge station is 5.86 in. (ARL/SORD, 2005).

\section{B.2.2.5 Migration Pathways and Transport Mechanisms}

Migration pathways of potential contaminants include the lateral movement of potential contaminants across surface soils/sediments and vertical movement into and through subsurface soils. An important element of the CSM in developing a sampling strategy is the expected fate and transport of contaminants (how contaminants migrate through media and where they can be expected in the 
environment). Fate and transport of contaminants are presented in the CSM as the migration pathways and transport mechanism that could potentially move the contaminants throughout the various media. Fate and transport are influenced by physical and chemical characteristics of the contaminants and media described in Sections B.2.2.3 and B.2.2.4.

Due to the nature of the suspected COPCs, the preferential pathways at the CASs are limited to vertical migration due to gravity, minor changes within the soil, or confining (impermeable) layers redirecting flow direction, which is always gravity driven to low points. Infiltration and percolation of precipitation serves as a driving force for downward migration of contaminants. However, due to the high potential annual evapotranspiration and the limited precipitation at the CASs, percolation of infiltrated precipitation at the NTS does not provide a significant mechanism for contaminants to impact groundwater (DOE/NV, 1992).

Contaminants can be expected to be found relatively close to release points or in low areas where settling may occur and evaporation will concentrate constituents. Infiltration of COPCs beyond shallow subsurface soil is not a concern at these CASs. The contaminated subsurface soil at CAS 06-44-06 is limited to a small area around the former UST 6-CP-9. The most likely route of subsurface (greater than $5.0 \mathrm{ft}$ bgs) migration is vertically through the porous alluvial soil. However, further migration of hydrocarbons in the soil is not expected because the potential source (e.g., spill and/or overfill) of hydrocarbons was removed when the tank and the surrounding impacted fill material and soil were removed. The remaining hydrocarbons are in the subsurface soil. Analytical results show TPH-DRO detected at a concentration of $220 \mathrm{mg} / \mathrm{kg}$ at $16 \mathrm{ft}$ bgs and a TPH FSR of $330 \mathrm{ppm}$ at $19 \mathrm{ft}$ bgs (DOE/NV, 1998).

Surface ( $0 \mathrm{ft}$ to $0.5 \mathrm{ft}$ bgs) and shallow subsurface $(0.5 \mathrm{ft}$ to $5.0 \mathrm{ft}$ bgs $)$ soil northeast and northwest of the former UST has also been impacted by hydrocarbons and potentially other chemical constituents as a result of a historic spill(s) and/or other activities possibly unrelated to UST 6-CP-9. The preferred route of migration pathway for hydrocarbons that may migrate from the surface soil would be a result of stormwater runoff. The site slopes to the northeast; therefore, migration would be expected in this direction. The hydrocarbon-impacted shallow surface from $0.5 \mathrm{ft}$ to $2.0 \mathrm{ft}$ soil is not expected to create additional runoff of hydrocarbons because of soil overlaying these areas. Therefore, the most likely migration pathway is vertically as a result of precipitation. Vertical 
migration of hydrocarbons is not expected to continue as the source has been removed (DOE/NV, 1998).

While contaminants within a weathered hydrocarbon spill/release may cover a visible area, they will tend to be present in higher concentrations near the point of discharge and decrease with increasing distance from the point of discharge both laterally and vertically. For example, petroleum-based fuels in soil tend to be found in higher concentrations near the surface shortly after the spill/leak, then tend to decrease as environmental processes work to reduce the concentrations where such factors as volatilization, microbial degradation, and photodegradation are most effective (i.e., at the surface). Just below the surface, these environmental processes are retarded, thereby resulting in less natural attenuation and greater residual concentration. Other factors such as adsorption to soil particles and vertical transport with precipitation also enhance the hydrocarbon concentrations within the shallow subsurface. Sampling in these preferential locations will increase the probability of detecting contamination if it is present anywhere within the CAS boundary.

Vertical infiltration of COPCs is assumed to be limited because the lateral area of contamination does not suggest a large volume of contaminants was released. Because there is no physical barrier beneath or adjacent to the releases and the CASs reside on generally flat topography, downward vertical migration will be predominant over lateral migration. However, lateral migration may be predominant at CAS 12-29-06 and CAS 23-25-01, due to the presence of asphalt on the soil surface that would hinder infiltration. At CAS 06-44-06, where release occurrences were likely to be frequently repeated over time, vertical infiltration is expected to be greater than areas that experienced a one-time spill.

Contamination, if present, is expected to be primarily confined to the immediate area covered by the spill/release. Unsaturated conditions, due to arid climate, limit the potential for lateral or vertical migration into surrounding soils.

\section{B.2.2.6 Exposure Scenarios}

The exposure of workers and visitors to site contaminants is very dependent upon activities of the exposed indivudials at each contaminated site. To facilitate calculation of Tier 2 SSTLs, three exposure scenarios were developed to represent potential exposures to soil contamination at the NTS 
based on the type of site, the time workers are present at the site, and the projected future used of the site. Each contaminated site will be categorized into one of three types - Industrial Area, Remote Work Area, Occasional Use Area - and are described in Table B.2-4.

Table B.2-4

Exposure Scenarios for CAU 538 Corrective Action Sites

\begin{tabular}{||c|c|l||}
\hline $\begin{array}{c}\text { Corrective } \\
\text { Action Site }\end{array}$ & $\begin{array}{c}\text { Exposure } \\
\text { Scenario }\end{array}$ & \multicolumn{1}{c|}{ Criteria } \\
\hline \hline $06-44-06$ & Industrial Area & $\begin{array}{l}\text { Assumes continued industrial use of a site. This scenario addresses exposure to } \\
\text { industrial workers exposed daily to contaminants in soil during an average } \\
\text { workday. This scenario assumes that this is the regular assigned work area for } \\
\text { the worker who will be on the site for an entire career (225 days per year, 10 hours } \\
\text { per day for 25 years). }\end{array}$ \\
\hline $02-21-01$ & $\begin{array}{l}\text { Occasional Use } \\
\text { Area }\end{array}$ & $\begin{array}{l}\text { Assumes occasional work activities at a site. This scenario addresses exposure } \\
\text { to industrial workers who are not assigned to the area as a regular worksite but } \\
\text { may occasionally use the site. This scenario assumes that this is an area where } \\
\text { the worker does not regularly visit but may occasionally use for short-term } \\
\text { activities. }\end{array}$ \\
\hline $06-09-01$ & Remote Work Area & $\begin{array}{l}\text { Assumes non-continuous work activities at a site. This scenario addresses } \\
\text { exposure to industrial workers exposed to contaminants in soil during a portion of } \\
\text { an average workday. This scenario assumes that this is an area where the worker } \\
\text { regularly visits but is not an assigned work area where the worker spends an } \\
\text { entire workday. }\end{array}$ \\
\hline
\end{tabular}

Source: Kidman, 2005

Site workers may be exposed to COCs through oral ingestion, inhalation, external exposure to radiation, or dermal contact (by absorption) of COCs absorbed into the soils. Exposure is due to inadvertent disturbance of the contaminated soils and/or contaminated structures.

Corrective Action Sites 06-44-06 and 23-25-01 are located nearby active structures within the active areas of the NTS (i.e., Areas 6 and 23). Although no facilities are present at these sites that would allow them to be used as an assigned work station for NTS, site personnel may periodically perform work (i.e., emergency preparedness training) at these sites, and facilities could be conceivably constructed at the location of the CAS. Therefore, both CASs 06-44-06 and 23-25-01 are classified as industrial areas.

Corrective Action Site 06-09-01 is located nearby the active Well 3 Yard. Although facilities are present, it is assumed that non-continuous work activities would be conducted at this site, where 
workers regularly visit but are not assigned work where they would spend an entire day. Therefore, this site is classified as a remote work area.

Corrective Action Sites 02-21-01, 03-25-04, 06-44-05, and 12-29-06 are at remote locations without any site improvements and where no regular work is performed. There is still the possibility, however, that site workers could occupy these locations on an occasional and temporary basis such as a military exercise. Therefore, these sites are classified as an occasional work area.

The defined land use zones at the NTS (DOE/NV, 1996) for the CASs in CAU 538 specify future land uses that are consistent with current land uses. The nature of the future land-use zones precludes the presence of site workers except on an occasional or temporary basis during testing activities. The future land-use zones for CAU 538 are described in Table B.2-5.

Table B.2-5

Future Land-Use Zones for CAU 538 Corrective Action Sites

\begin{tabular}{|c|c|c|}
\hline $\begin{array}{l}\text { Corrective } \\
\text { Action Site }\end{array}$ & Zone & Zone Description \\
\hline $\begin{array}{l}02-21-01 \\
03-25-04 \\
12-29-06\end{array}$ & $\begin{array}{l}\text { Nuclear and High } \\
\text { Explosives Test }\end{array}$ & $\begin{array}{l}\text { This area is designated within the Nuclear Test Zone for additional } \\
\text { underground nuclear weapons tests and outdoor high-explosive tests. } \\
\text { This zone includes compatible defense and nondefense research, } \\
\text { development, and testing activities. }\end{array}$ \\
\hline $06-09-01$ & $\begin{array}{l}\text { Research, Test, and } \\
\text { Experiment }\end{array}$ & $\begin{array}{l}\text { This area is designated for small-scale research and development projects } \\
\text { and demonstrations; pilot projects; outdoor tests; and experiments for the } \\
\text { development, quality assurance, or reliability of material and equipment } \\
\text { under controlled conditions. This zone includes compatible defense and } \\
\text { nondefense research, development and testing projects, and activities. }\end{array}$ \\
\hline $06-44-06$ & Defense Industrial & $\begin{array}{l}\text { This area is designated for stockpile management of weapons, including } \\
\text { production, assembly, disassembly or modification, staging, repair, retrofit, } \\
\text { and surveillance. Also included in this zone are permanent facilities for } \\
\text { stockpile stewardship operations involving equipment and activities such } \\
\text { as radiography, lasers, material processing, and pulsed power. }\end{array}$ \\
\hline $\begin{array}{l}06-44-05 \\
23-25-01\end{array}$ & Reserved & $\begin{array}{l}\text { This area includes land and facilities that provide widespread flexible } \\
\text { support for diverse short-term testing and experimentation. The reserved } \\
\text { zone is also used for short duration exercises and training such as nuclear } \\
\text { emergency response and Federal Radiological Monitoring and } \\
\text { Assessment Center training and U.S. Department of Defense } \\
\text { land-navigation exercises and training. }\end{array}$ \\
\hline
\end{tabular}

Source: DOE/NV, 1996 


\section{B.3.0 Step 2 - Identify the Decisions}

Step 2 of the DQO process identifies the decision statements and defines the appropriate actions to be taken based upon the answer to the decision statements. Figure B.3-1 depicts the sequential flow of questions, answers, and action alternatives required to fulfill the objectives of the SAFER process.

\section{B.3.1 Decision Statements}

Decision I: "Does any COC exist in the environmental media within the CAS?" A COC is defined as any contaminant that is present in an environmental medium (e.g., soil) at concentrations exceeding its respective FAL.

Decision II: "Is sufficient information available to confirm that closure objectives were met?" Sufficient information is defined to include:

- Information (e.g., analytical results) necessary to identify the lateral and vertical extent of contamination in the environmental medium

- Information necessary to select the appropriate corrective action to complete closure of the site

- Information to necessary to confirm that the chosen closure objectives were met

If sufficient information is not available to confirm that closure objectives were met, then site conditions will be re-evaluated, and additional samples will be collected (as long as the scope of the investigation is not exceeded, any CSM assumption has not been shown to be incorrect, and SAFER criteria are not violated). With respect to CAS 06-09-01, a detailed site walkover will be conducted to determine whether any biasing factors listed in Section B.4.2.1 exist at this CAS. If no environmental concerns are identified at this CAS, then no further action is the chosen corrective action. If any environmental concerns are identified at this CAS, then Decisions I and II will apply.

\section{B.3.2 Alternative Actions to the Decisions}

In this section, the actions that may be taken to solve the problem are identified depending on the possible outcomes of the investigation. 


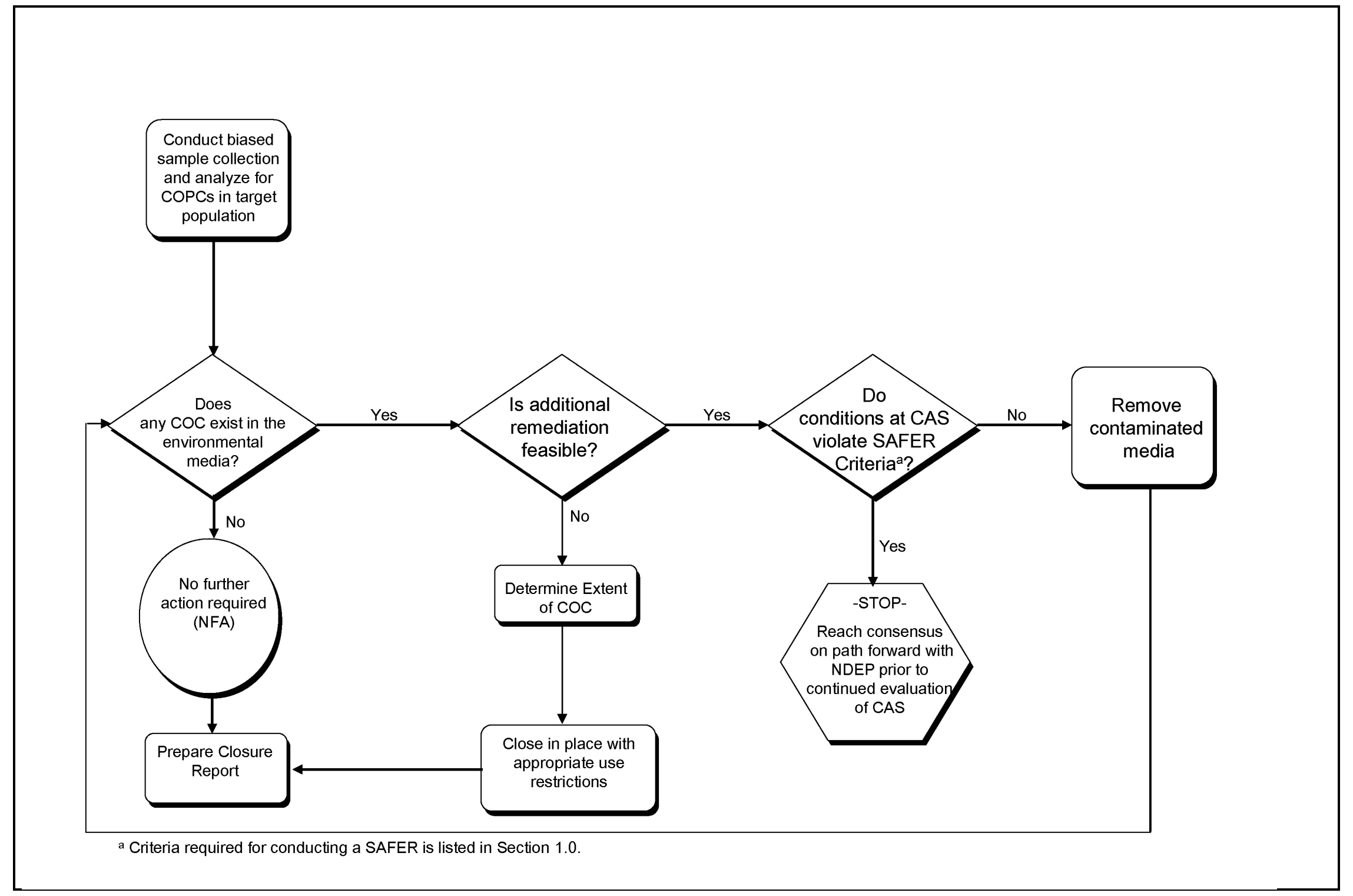

Figure B.3-1

SAFER Closure Decision Process for CAU 538

\section{Uncontrolled When Printed}




\section{B.3.2.1 Alternative Actions to Decision I}

If no COC associated with a release from the CAS is detected, then further assessment of the CAS is not required, and the corrective action alternative of no further action will be selected. If a COC associated with a release from the CAS is detected, then additional sampling will be conducted to determine the extent of COC contamination. If the extent of the contamination is defined and additional remediation is feasible, then clean close the site by removing the contaminated media until all contamination has been removed, and collect verification samples from the remaining soil. If the extent of contamination has been determined and additional remediation is not feasible, then the extent of contamination will be defined and the contaminated area will be closed in place with appropriate use restrictions.

If the collection of verification samples confirm that all the contaminated media has been removed, then the clean closure objectives will have been met. If contamination still exists and additional remediation would violate the SAFER criteria, then work will stop and a consensus reached with NDEP on the path forward before continuing the investigation of the CAS.

\section{B.3.2.2 Alternative Actions to Decision II}

If sufficient information is available to define the extent of COC contamination and confirm that closure objectives were met, then further assessment of the CAS is not required. If sufficient information is not available to define the extent of contamination or confirm that closure objectives were met, then additional samples will be collected until the extent is defined. 


\section{B.4.0 Step 3 - Identify the Inputs to the Decision}

This step identifies the information needed, determines sources for information, and identifies sampling and analysis methods that will allow reliable comparisons of analytical results with FALs.

\section{B.4.1 Information Needs}

To resolve Decision I (determine whether a COC is present at a given CAS), samples must be collected and analyzed using the following criteria:

- Samples must be collected in areas most likely to contain COCs based on biasing factors (e.g., staining).

- The selected analytical suite must be comprehensive in order to identify any COCs present in the samples.

- Analytical methods selected must have minimum detectable concentrations (MDCs) equal to or less than their corresponding PALs.

To resolve Decision II (determine whether sufficient information is available to confirm that closure objectives were met at each CAS), samples must be collected and analyzed to meet the following criteria:

- Samples must be collected in areas contiguous to the contamination but where contaminant concentrations are below FALs.

- Samples of the contaminated environmental media must provide sufficient information to characterize for disposal.

- Samples of the contaminated environmental media must provide sufficient information to determine potential remediation waste types.

- Samples of the native soil beneath the removed contaminated environmental media must provide sufficient information to verify that all contamination as been successfully removed.

- The analytical suites selected must be sufficient to detect COCs at concentrations equal to or less than their corresponding FAL.

- Analytical methods selected must have MDCs equal to or less than their corresponding PAL. 


\section{B.4.2 Sources of Information}

Information to satisfy Decision I and Decision II will be generated by collecting environmental samples using sampling methods that include grab sampling, hand auguring, direct push, backhoe excavation, or drilling. These samples will be submitted to analytical laboratories meeting the quality criteria stipulated in the Industrial Sites QAPP (NNSA/NV, 2002). Only validated data from analytical laboratories will be used to make DQO decisions. Sample collection and handling activities will follow standard procedures.

\section{B.4.2.1 Sample Locations}

Decision I samples must be collected at locations most likely to contain a COC, if present. These locations will be selected based on field-screening techniques, biasing factors, and the CSM. Analytical suites for Decision I samples will include all COPCs identified in Table B.2-3. Planned sample locations are shown in figures located in Section B.8.0. The number and exact location will be adjusted by the Site Supervisor during the investigation based on the biasing criteria contained in this section.

Field-screening techniques may be used to select appropriate sampling locations by providing semiquantitative data that can be used to comparatively select samples to be submitted for laboratory analyses from several screening locations. Field screening may also be used for health and safety monitoring and to assist in making certain health and safety decisions. The following field-screening methods may be used to select CAU 538 samples for off-site laboratory analysis:

- Headspace Analysis: The FSLs for VOCs are 20 ppm or 2.5 times background, whichever is greater. A PID, or an equivalent instrument or method, will be used to conduct headspace analysis at all CASs, because VOCs are a common concern at the NTS and have not been ruled out based on process knowledge.

- Gas Chromatography: The TPH FSRs greater than 75 ppm measure using a gas chromatograph, or equivalent equipment or method, may be used to field screen samples.

- Radiological Surveys: Alpha and beta/gamma radiation can be detected by using an NT Technology Electra, or equivalent instrument or method, to survey individual samples or areas. The FSLs for soil are established for each CAS as the mean background activity plus two times the standard deviation of the mean background activity. 
- Walkover Surface Area Radiological Surveys: A plastic scintillator may be used over as much of the CAS boundaries as permitted by terrain and field conditions to detect hot spots of radiological contamination.

- Gamma Spectroscopy: The identification of gamma-emitting radionuclides may be conducted by gamma spectroscopy, or an equivalent instrument or method, on samples that show an elevated total alpha or beta/gamma FSR, and/or comply with transportation requirements.

Biasing factors may also be used to select samples to be submitted for laboratory analyses based on existing site information and site conditions discovered during the investigation. The following factors will be considered in selecting locations for analytical samples at CAU 538:

- Process knowledge of sources and location of release (e.g., documented location of release). Locations that may reasonably have been contaminated based on the results of previous field investigations.

- Stains: Any spot or area on the soil surface that may indicate the presence of a potentially hazardous liquid. Typically, stains indicate an organic liquid such as an oil has reached the soil, and may have spread out vertically and horizontally.

- Elevated Radiation: Any location identified during radiological surveys having alpha/beta/gamma levels significantly higher than surrounding background soil.

- Geophysical Anomalies: Any location identified during geophysical surveys that have results indicating subsurface materials existed and were not consistent with the natural surroundings (e.g., buried concrete or metal).

- Debris: Presence of materials of interest such as debris, waste, or equipment that may have been used at, or added to, a location and may have come in contact with hazardous substances at some point during their use.

- Lithology: Locations where variations in lithology (soil or rock) indicate that different conditions or materials exist.

- Site History: Locations for which evidence such as historical photographs, process knowledge, existing data, and experience from previous investigations and/or interviewee input exists that a release of hazardous or radioactive substances may have occurred.

- Additional Biasing Factors: Any other indication of potential contamination such textural discontinuities, disturbance of native soils, or odor. 
Decision II sample step-out locations will be selected based on the CSM, biasing factors, and existing data. Analytical suites will include those parameters that exceeded FALs (i.e., COCs) in previous samples. Biasing factors to support Decision II sample locations include Decision I biasing factors plus available analytical results.

\section{B.4.2.2 Analytical Methods}

Analytical methods are available to provide the data needed to resolve the decision statements. The analytical methods and laboratory requirements (e.g., detection limits, precision, and accuracy) are provided in Tables 7-2 and 7-3. 


\section{B.5.0 Step 4 - Define the Boundaries of the Study}

The purpose of this step is to define the population of interest, define the spatial boundaries, determine practical constraints on data collection, and define the scale of decision making.

\section{B.5.1 Populations of Interest}

The population of interest to resolve Decision I ("Is any COC present in environmental media within the CAS?") is any single location within the site that is contaminated with any contaminant above a FAL. The populations of interest to resolve Decision II ("If a COC is present, is sufficient information available to confirm that closure objectives were met?") are:

- Locations bounding contamination in lateral and vertical directions (i.e., step-out sample locations)

- Investigation-derived waste or environmental media that must be characterized for disposal (i.e., waste characterization samples).

- Locations adjacent to remediated soil (i.e., verification samples)

\section{B.5.2 Spatial Boundaries}

Spatial boundaries are the maximum lateral and vertical extent of expected contamination at each CAS, as shown in Table B.5-1. Contamination found beyond these boundaries may indicate a flaw in the CSM and may require re-evaluation of the CSM before the investigation can continue. Each CAS is considered geographically independent, and intrusive activities are not intended to extend into the boundaries of neighboring CASs.

\section{B.5.3 Practical Constraints}

Practical constraints such as military activities at the NTS, weather (i.e., high winds, rain, lightning, extreme heat), utilities, threatened or endangered animal and plants, unstable or steep terrain, and/or access restrictions may affect the ability to investigate this site. The practical constraints associated with the investigation of the CAU 538 CASs are summarized in Table B.5-2. 
Table B.5-1

Spatial Boundaries of CAU 538 CASs

\begin{tabular}{||c|l|}
\hline Corrective Action Site & \multicolumn{1}{c|}{ Spatial Boundaries } \\
\hline \hline $02-21-01$ & 300 by 120 ft laterally, and 100 ft bgs vertically \\
\hline $03-25-04$ & $\begin{array}{l}\text { Concrete building foundation adjacent to the north and west sides of CAS and 100 ft bgs } \\
\text { vertically }\end{array}$ \\
\hline $06-09-01$ & Approximately 900 by 400 ft laterally \\
\hline $06-44-05$ & $\begin{array}{l}\text { Concrete pad adjacent to the east and south sides of the CAS, a precipice 21 ft from the } \\
\text { west side of the CAS, and 100 } \mathrm{ft} \text { bgs vertically }\end{array}$ \\
\hline $06-44-06$ & $\begin{array}{l}\text { Concrete pad housing generators (Building CP-15) directly south of the former UST } \\
\text { location and associated land use restriction (see Appendix C); TPH-DRO contamination } \\
\text { extends approximately 60 ft north of the land use restriction and 100 } \mathrm{ft} \text { bgs vertically }\end{array}$ \\
\hline $12-29-06$ & $100 \mathrm{ft}$ bgs vertically \\
\hline $23-25-01$ & $100 \mathrm{ft}$ bgs vertically \\
\hline
\end{tabular}

bgs = Below ground surface

$\mathrm{DRO}=$ Diesel-range organics

$\mathrm{ft}=$ Foot

$\mathrm{TPH}=$ Total petroleum hydrocarbons

UST $=$ Underground storage tank

\section{B.5.4 Define the Scale of Decision Making}

The scale of decision making in Decision I is defined as the CAS. Any COC detected at any location within the CAS will cause the determination that the CAS is contaminated and needs further evaluation. The scale of decision making for Decision II is defined as a contiguous area contaminated with any COC originating from the CAS. Resolution of Decision II requires this contiguous area to be bounded laterally and vertically. 
Table B.5-2

Practical Constraints for the CAU 538 Field Investigation

\begin{tabular}{|c|c|}
\hline Corrective Action Site & Practical Constraints \\
\hline 02-21-01 & $\begin{array}{l}\text { Weather (i.e., high winds, rain, lightning, extreme heat), } \\
2 \text { oa Crater fence boundary, and loose and unconsolidated terrain }\end{array}$ \\
\hline $03-25-04$ & $\begin{array}{l}\text { Weather (i.e., high winds, rain, lightning, extreme heat), } \\
\text { underground utilities, concrete pads adjacent to the north and } \\
\text { west sides of the impacted soil, presence of PACM floor tiles on } \\
\text { building foundation to the west and adjacent to the CAS. }\end{array}$ \\
\hline 06-09-01 & $\begin{array}{l}\text { Weather (i.e., high winds, rain, lightning, extreme heat), restricted } \\
\text { access due to NTS activities, and loose and unconsolidated } \\
\text { terrain }\end{array}$ \\
\hline $06-44-05$ & 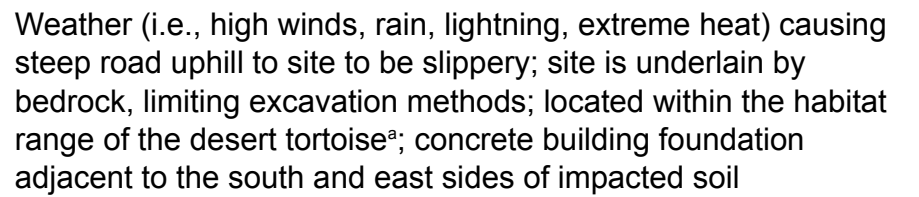 \\
\hline $06-44-06$ & $\begin{array}{l}\text { Weather (i.e, high winds, rain, lightning, extreme heat); CAS } \\
\text { within fenced Control Point complex; Q-clearance or escort by } \\
\text { Q-cleared individual required; complexity of underground utilities } \\
\text { in use restriction may require substantial hand excavating; } \\
\text { located within the habitat range of the desert tortoisea; electrical } \\
\text { lines, water, sewer, and communication lines; fuel line running } \\
\text { from AST; generators (Building CP-15) adjacent to former UST } \\
\text { 6-CP-9; and fence adjacent to north side of the impacted soil }\end{array}$ \\
\hline $12-29-06$ & $\begin{array}{l}\text { Weather (i.e., high winds, rain, lightning, warm temperatures), } \\
\text { military exercises, underground utilities, power substation, and } \\
\text { aboveground utilities }\end{array}$ \\
\hline $23-25-01$ & $\begin{array}{l}\text { Weather (i.e., high winds, rain, lightning, extreme heat), } \\
\text { underground utilities, located within the habitat range of the } \\
\text { desert tortoise } e^{\text {a. }} \text { building foundation within CAS }\end{array}$ \\
\hline
\end{tabular}

${ }^{a}$ Mojave Desert population of the desert tortoise is listed as a threatened species by the U.S. Fish and Wildlife Service (DOE/NV, 1996).

AST = Aboveground storage tank

bgs $=$ Below ground surface

$\mathrm{ft}=$ Foot

NTS $=$ Nevada Test Site

$\mathrm{PACM}=$ Presumed asbestos-containing material

UST $=$ Underground storage tank 


\section{B.6.0 Step 5 - Develop a Decision Rule}

This step develops a decision rule ("If..., then...") statement that defines the conditions under which possible alternative actions will be chosen. In this step, we specify the parameters that characterize the population of interest, specify the FALs, confirm that analytical detection limits are capable of detecting FALs, and present decision rules.

\section{B.6.1 Population Parameters}

Each sample result representing each population of interest, defined in Step 4, will be compared to the FALs to determine the appropriate resolution to Decision I and Decision II. For the Decision I population of interest, a single analytical sample result above FALs would cause a determination that a COC is present within the CAS. For the Decision II population of interest, a single analytical sample result above FALs would cause a determination that the contamination is not bounded in one direction.

Because this approach does not use a statistical average for comparison to the FALs, but rather a point-by-point comparison, the population parameter for both populations of interest is the observed concentration of each analyte from individual analytical sample results.

\section{B.6.2 Decision Rules}

The decision rules applicable to both Decision I and Decision II are:

- If COC contamination is inconsistent with the CSM or extends beyond the spatial boundaries identified in Section B.5.2, then work will be suspended and the investigation strategy will be reconsidered. If a COC is present, is consistent with the CSM, and is within spatial boundaries, then the decision will be to continue sampling to define the extent.

The decision rules for Decision I are:

- If the population parameter (the observed concentration of each analyte) of any COPC in the Decision I population of interest (defined in Step 4) exceeds the corresponding FAL, then that analyte is identified as a COC, the contaminated material will be removed, or Decision II samples will be collected until an estimate of the extent of contaminated material has been made. 
- If no COC associated with a release from the CAS is detected, then further assessment of the CAS is not required and the corrective action alternative of no further action will be selected. If a COC associated with a release from the CAS is detected, then additional sampling will be conducted to determine the extent of COC contamination. If the extent of the contamination is defined and additional remediation is feasible, then clean close the site by removing the contaminated media until all contamination has been removed. If the extent of contamination has been determined and additional remediation is not feasible, then the contaminated area will be close in place with appropriate use restrictions and the extent of contamination defined.

The decision rules for Decision II are:

- If the population parameter (the observed concentration of any COC) in the Decision II step-out population of interest (defined in Step 4) exceeds the corresponding FAL, then additional samples will be collected to complete the Decision II evaluation. If sufficient information is available to define the extent of COC contamination and confirm that closure objectives were met, then further assessment of the CAS is not required. If sufficient information is not available to define the extent of contamination or confirm that closure objectives were met, then additional samples will be collected until the extent is defined.

- If valid analytical results are available for the waste characterization samples defined in Section B.8.0, then the decision will be that sufficient information exists to characterize the remediation waste for disposal.

\section{B.6.3 Action Levels}

The PALs presented in this section are to be used for sample screening purposes. They are not necessarily intended to be used as cleanup action levels or FALs. However, they are useful in screening out analytes that are not present in sufficient concentrations to warrant further evaluation and, therefore, streamline the consideration of remedial alternatives. The process that will be used to move from PALs to FALs is that specified by NAC 445A.22705 (NAC, 1997). This regulation stipulates that determination of FALs shall be established by an evaluation of the site based on the risk it poses to public health and the environment. This evaluation will be conducted using Method E1739-95, adopted by the ASTM (ASTM, 1995). The ASTM's RBCA process uses three tiers of increasing complexity and is summarized in Section 3.2.1. The Tier 1 action levels are the PALs. The specific chemical PALs for CAU 538 are listed in Section 3.2.1.1. The specific radiological PALs for CAU 538 are listed in Section 3.2.1.3. The radiological FAL for solid media will be defined as the unrestricted-release criteria defined in the NV/YMP RadCon Manual (NNSA/NSO, 2005). 
If necessary, a Tier 2 or Tier 3 evaluation will be conducted by calculating SSTLs. If a Tier 2 or Tier 3 evaluation is conducted for TPH, the hazardous constituents of TPH will be compared to the SSTLs as the general measure of TPH provides insufficient information about the amounts of individual chemicals of concern within the TPH measurement.

The comparison of laboratory results to FALs and the evaluation of potential corrective actions will be included in the investigation report. The FALs will be defined (along with the basis for their definition) in the investigation report.

\section{B.6.4 Measurement and Analysis Sensitivity}

The measurement and analysis methods listed in Section 3.1 and in the Industrial Sites QAPP (NNSA/NV, 2002) are capable of measuring analyte concentrations at or below the corresponding FAL for each COPC. See Section 7.2 for additional details. 


\section{B.7.0 Step 6 - Tolerable Limits on Decision Errors}

The purpose of this step is to specify performance criteria for the decision rule. Setting tolerable limits on decision errors is neither obvious nor easy. It requires the planning team to weigh the relative effects of threat to human health and the environment, expenditure of resources, and consequences of an incorrect decision. Section 7.1 of the EPA QA/G-4HW guidance states that if judgmental sampling approaches are used, quantitative statements about data quality will be limited to measurement error (EPA, 2000a). Measurement error is influenced by imperfections in the measurement and analysis system. Random and systematic measurement errors are introduced in the measurement process during physical sample collection, sample handling, sample preparation, sample analysis, and data reduction. If measurement errors are not controlled, they may lead to errors in making the DQO decisions.

This section provides an assessment of the possible outcomes of DQO decisions and the impact of those outcomes if the decisions are in error.

The baseline condition (i.e., null hypothesis) and alternative condition for Decision I are:

- Baseline condition - A COC is present.

- Alternative condition - A COC is not present.

The baseline condition (i.e., null hypothesis) and alternative condition for Decision II are as follows:

- Baseline condition - The extent of a COC has not been defined and closure objectives were not met.

- Alternative condition - The extent of a COC has been defined and closure objectives were met.

Decisions and/or criteria have false negative or false positive errors associated with their determination. The impact of these decision errors and the methods that will be used to control these errors are discussed in the following subsections. In general terms, confidence in DQO decisions based on judgmental sampling results will be established qualitatively by:

- The development of and concurrence of the CSM (based on process knowledge) by stakeholder participants during the DQO process. 
- Testing the validity of the CSM based on investigation results.

- Evaluating the quality of the data based on DQI parameters.

\section{B.7.1 False Negative Decision Error}

The false negative decision error would mean deciding that a COC is not present when it actually is (Decision I), or deciding that the extent of a COC has been defined when it has not (Decision II), or deciding that closure objectives were met when they were not (Decision II). In all of these cases, the potential consequence is an increased risk to human health and environment.

The false negative decision error (where consequences are more severe) is controlled by meeting these criteria:

1. For Decision I, having a high degree of confidence that the sample locations selected will identify COCs if present anywhere within the CAS. For Decision II, having a high degree of confidence that the sample locations selected will identify the extent of COCs.

2. Having a high degree of confidence that analyses conducted will be sufficient to detect any COCs present in the samples.

3. Having a high degree of confidence that the dataset is of sufficient quality and completeness.

To satisfy the first criterion, Decision I samples must be collected in areas most likely to be contaminated by COCs. Decision II samples must be collected in areas that represent the lateral and vertical extent of contamination (above FALs). The following characteristics must be considered to control decision errors for the first criterion:

- Source and location of release

- Chemical nature and fate properties

- Physical transport pathways and properties

- Hydrologic drivers

These characteristics were considered during the development of the CSM and the selection of sampling locations. The field-screening methods and biasing factors listed in Section B.4.2.1 will be used to further ensure that appropriate sampling locations are selected to meet these criteria. Radiological survey instruments and field-screening equipment will be calibrated and checked according to the manufacturer's instructions and approved procedures. The investigation report will 
present an assessment on the DQI of representativeness that samples were collected from those locations that best represent the populations of interest as defined in Section B.5-1.

To satisfy the second criterion, Decision I samples will be analyzed for the chemical and radiological parameters listed in Section 4.1. Decision II samples will be analyzed for those chemical and radiological parameters that identified unbounded COCs. The DQI of sensitivity will be assessed for all analytical results to ensure that all sample analyses had measurement sensitivities (detection limits) that were less than or equal to the corresponding FALs. If this criterion is not achieved, the affected data will be assessed (for usability and potential impacts on meeting site characterization objectives) in the investigation report.

To satisfy the third criterion, the entire dataset, as well as individual sample results, will be assessed against the DQIs of precision, accuracy, comparability, and completeness as defined in the Industrial Sites QAPP (NNSA/NV, 2002) and in Section 7.2 of this SAFER Plan. The DQIs of precision and accuracy will be used to assess overall analytical method performance as well as to assess the need to potentially "flag" (qualify) individual analyte results when corresponding QC sample results are not within the established control limits for precision and accuracy. Data qualified as estimated for reasons of precision or accuracy may be considered to meet the analyte performance criteria based on an assessment of the data. The DQI of completeness will be assessed to ensure that all data needs identified in the DQO have been met. The DQI of comparability will be assessed to ensure that all analytical methods used are equivalent to standard EPA methods so that results will be comparable to regulatory action levels that have been established using those procedures. Strict adherence to established procedures and QA/QC protocol protects against false negatives. To provide information for the assessment of the DQIs of precision and accuracy, the following quality control samples will be collected as required by the Industrial Sites QAPP (NNSA/NV, 2002):

- Field duplicates (minimum of 1 per matrix, per 20 environmental samples)

- Laboratory QC samples (minimum of 1 per matrix, per 20 environmental samples, or 1 per CAS per matrix, if less than 20 collected) 


\section{B.7.2 False Positive Decision Error}

The false positive decision error would mean deciding that a $\mathrm{COC}$ is present when it is not, or a $\mathrm{COC}$ is unbounded when it is not, resulting in increased costs for unnecessary sampling and analysis, and potential remediation costs.

The false positive decision error is controlled by implementing all the controls that protect against false negative decision errors. False positive results are typically attributed to laboratory and/or sampling/handling errors that could cause cross contamination. To control against cross contamination, decontamination of sampling equipment will be conducted according to established and approved procedures and certified clean sample containers will be used. To determine whether a false positive analytical result may have occurred, the following QC samples will be collected as required by the Industrial Sites QAPP (NNSA/NV, 2002):

- Trip blanks (1 per sample cooler containing VOC environmental samples)

- Equipment blanks (1 per sampling event for each type of decontamination procedure)

- Source blanks (1 per source material lot, per sampling event)

- Field blanks (minimum of 1 per 20 environmental samples with a minimum of one per CAS) 


\section{B.8.0 Step 7 - Optimize the Approach for Obtaining Data}

This section provides the general approach for obtaining the information necessary to resolve Decision I and Decision II. A judgmental (non-probabilistic) sampling scheme will be implemented to select sample locations and evaluate analytical results. Judgmental sampling allows the methodical selection of sample locations that target the populations of interest (defined in Step 4) rather than non-selective random locations. Random sample locations are used to generate average contaminant concentrations that estimate the true average ("characteristic") contaminant concentration of the site to some specified degree of confidence.

Because individual sample results, rather than an average concentration, will be used to compare to FALs, statistical methods to generate site characteristics will not be necessary. Section 0.4 .4 of the EPA Data Quality Objectives Process for Hazardous Waste Site Investigations (EPA, 2000a) guidance states that the use of statistical methods may not be warranted by program guidelines or site-specific sampling objectives. The need for statistical methods is dependent upon the decisions being made. Section 7.1 of the EPA QA/G-4HW guidance states that a non-probabilistic (judgmental) sampling approach is developed when there is sufficient information on the contamination sources and history to develop a valid CSM and to select specific sampling locations. This approach is used to confirm the existence of contamination at specific locations and provide information (such as extent of contamination) about specific areas of the site.

All sample locations will be selected to satisfy the DQI of representativeness in that samples collected from selected locations will best represent the populations of interest as defined in Section B.5.1. To meet this criterion, a biased sampling strategy will be used for Decision I to target areas with the highest potential for contamination, if it is present anywhere in the CAS. Sample locations will be determined based on process knowledge, previously acquired data, or the field-screening and biasing factors listed in Section B.4.2.1. If biasing factors are present in soils below locations where Decision I samples were removed, additional Decision I soil samples will be collected at depth intervals selected by the Site Supervisor based on biasing factors to a depth where the biasing factors are no longer present. The Site Supervisor has the discretion to modify the sample locations, but only if the modified locations meet the decision needs and criteria stipulated in this DQO. 
To meet the DQI of representativeness for step-out (Decision II) samples (that Decision II sample locations represent the population of interest as defined in Section B.5.1), sampling locations at each CAS will be selected based on the outer boundary sample locations where COCs were detected, the CSM, and other field-screening and biasing factors listed in Section B.4.2.1. In general, sample locations will be arranged in a triangular pattern around the Decision I location at distances based on site conditions, process knowledge, and biasing factors. If COCs extend beyond the initial step-outs, Decision II samples will be collected from incremental step-outs. Initial step-outs will be at least as deep as the vertical extent of contamination defined at the Decision I location and the depth of the incremental step-outs will be based on the deepest contamination observed at all locations. A clean sample (i.e., concentrations less than FALs) collected from each step-out direction (lateral or vertical) will define extent of contamination in that direction. The number, location, and spacing of step-outs and verification samples locations may be modified by the Site Supervisor, as warranted by site conditions.

The following sections discuss CAS-specific investigation activities, including proposed sample locations. As the sampling strategy for each CAS is developed, specific biasing factors will be described. In the absence of biasing factors, samples will be collected from the default sampling locations described for each CAS.

\section{B.8.1 Corrective Action Site CAS 02-21-01, Epoxy Tar Pit}

Excavation activities will be conducted at CAS 02-21-01 to confirm that no COPCs exist in the fluid-like material shown in the depressions (i.e., pits, drainage patterns) in historical aerial photographs and to determine whether the site could potentially have been used as a mud pit. To accomplish these tasks, two trenches will be excavated perpendicular to the historic drainage pattern to the native soil interface, and another smaller trench (e.g., pothole) will be excavated at the lowest surface point between the unknown substance. Four samples will be collected of the unknown substance from two locations. If any biasing factors are present, samples will be collected and analyzed for potential contaminates per the decision of the Site Supervisor. If field conditions indicate the possibility that the site was used as a mud pit, additional samples of the fill material will be collected and submitted for laboratory analysis. 
Any samples collected and submitted for off-site analysis will be analyzed in accordance with the methods listed in Table B.2-3. Figure B.8-1 is a ground-level photograph showing conditions of the site. The planned excavation and sample locations are shown in Figure B.8-2. Additional Decision I and Decision II sample locations will be selected based on biasing factors described in Section B.4.2.1.

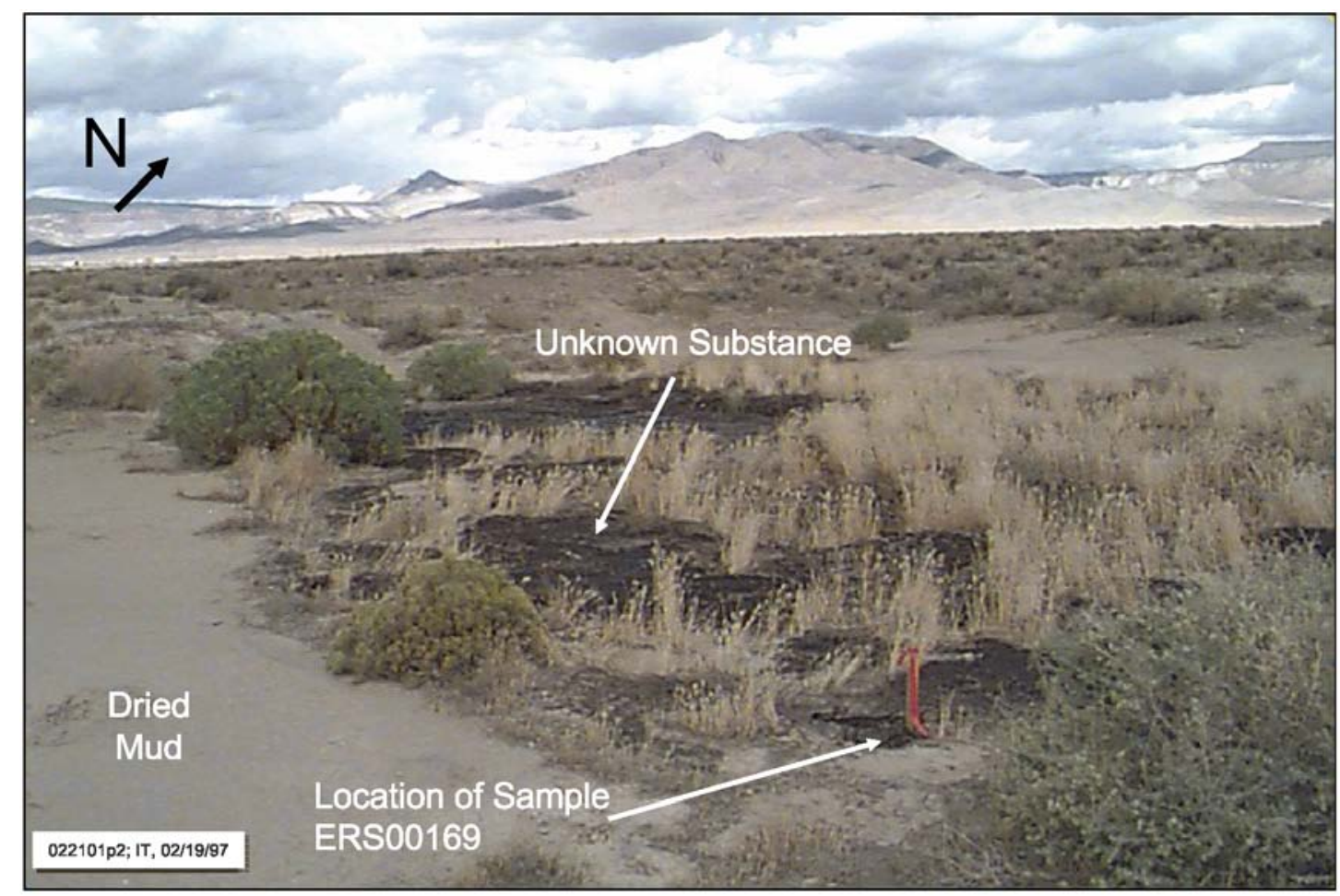

Figure B.8-1

Site Conditions at CAS 02-21-01

This photograph was taken at ground level and shows an overall view of the unknown substance at CAS 02-21-01. The substance is surrounded by dried mud within an excavated pit. Dense vegetation has grown throughout the area. Sample ERS00169 was taken at the location of the flagged wooden stake. The excavated pit lies within a larger depression or excavated pit. (IT, 1997)

\section{B.8.2 Corrective Action Site 03-25-04, Hydrocarbon Stain}

The biased sample locations at CAS 03-25-04 have been selected based on the stained surface soil at the location of the air compressor. Two Decision I sample locations are planned within the stain area. One sample will be collected from a stained surface area and one sample from the stained soil beneath the gravel layer. A subsequent interval below each sample will be collected and field screened. If FSRs exceed the FSLs and/or if biasing factors are present, the sample will be submitted for analysis. 


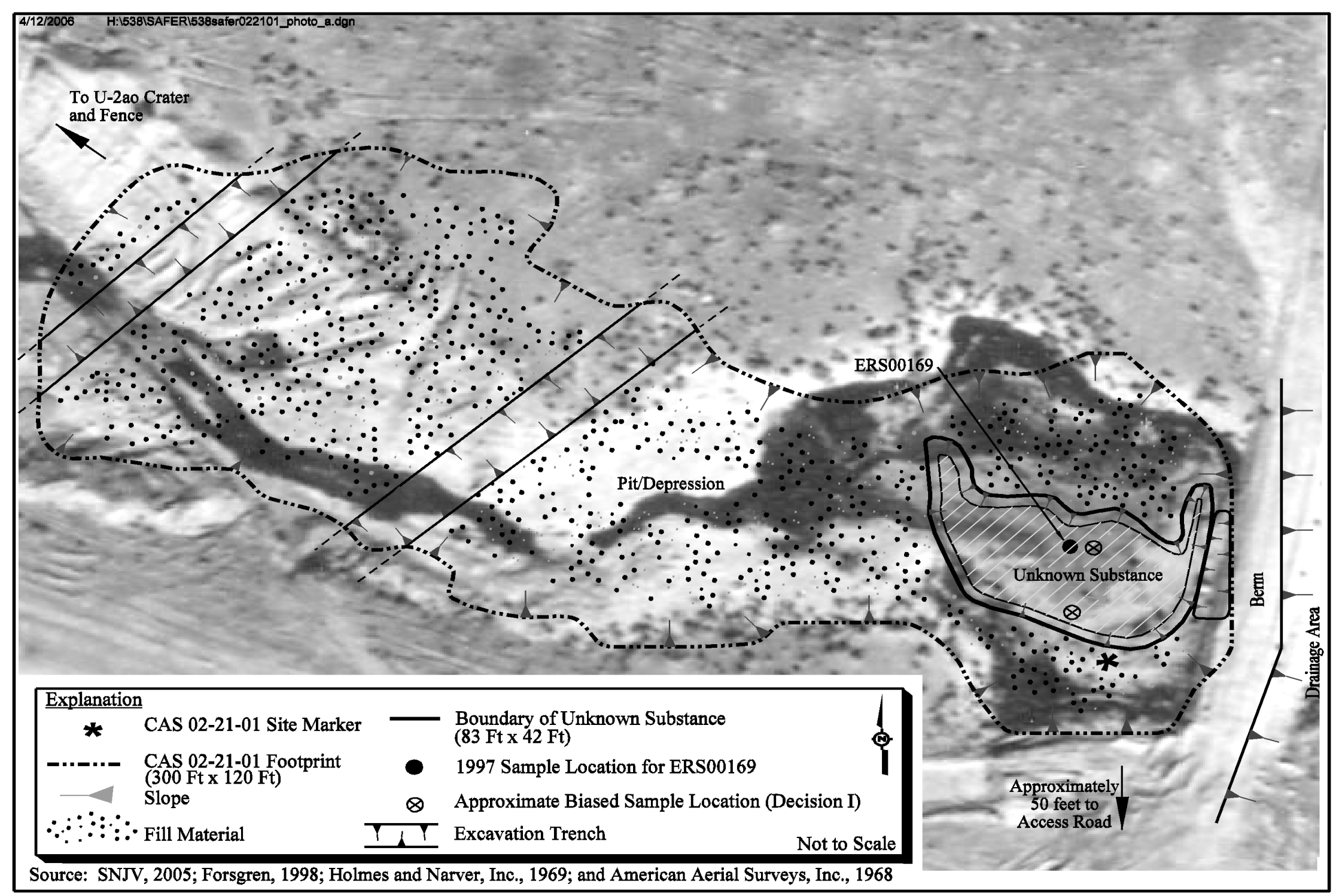

Figure B.8-2

CAS 02-21-01, Epoxy Tar Pit, Planned Sample Locations

\section{Uncontrolled When Printed}


Figure B.8-3 shows the site conditions of CAS 03-25-04. The planned Decision I sample locations are shown in Figure B.8-4. Additional Decision I and Decision II sample locations will be selected based on biasing factors described in Section B.4.2.1.

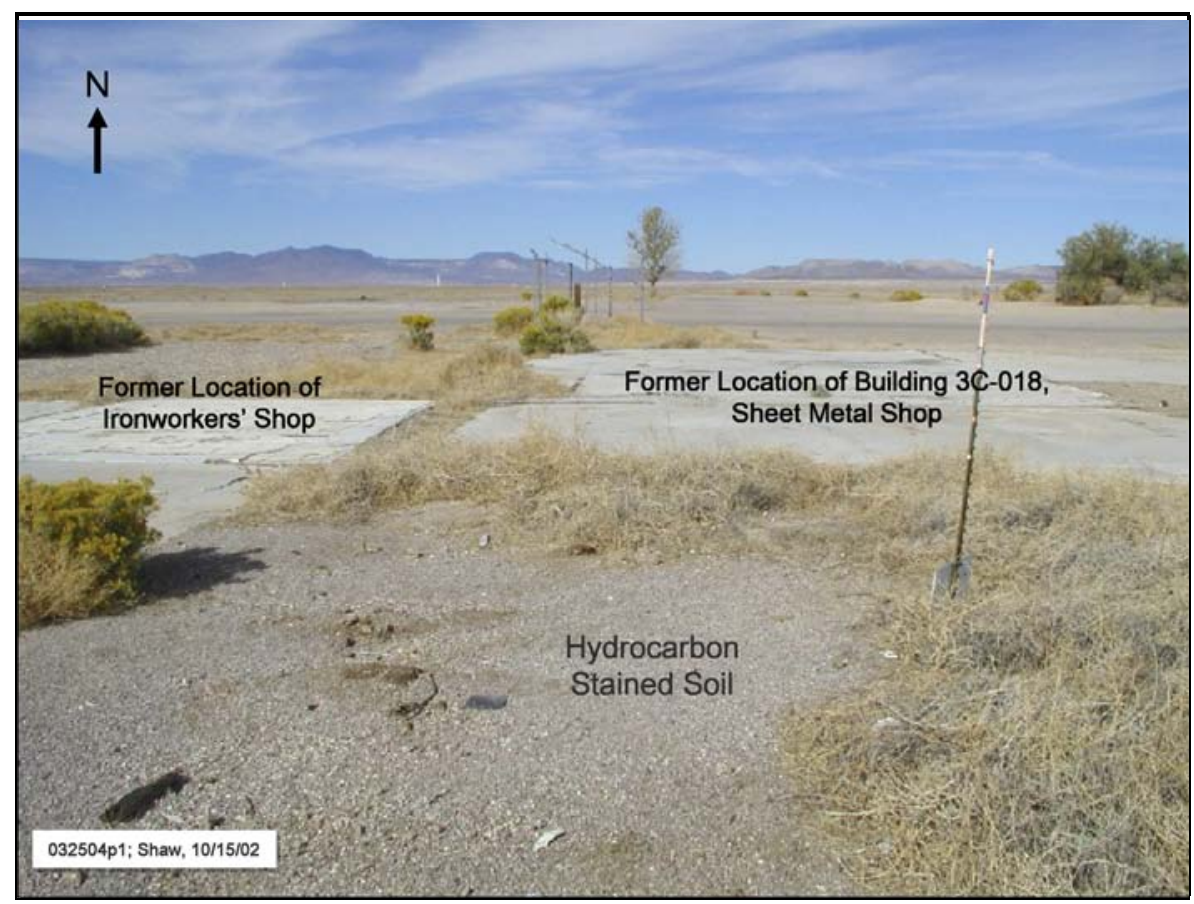

Figure B.8-3

Site Conditions at CAS 03-25-04

This photograph shows an overall view of the stained soil at CAS 03-25-04. (Shaw, 2002)

\section{B.8.3 Corrective Action Site 06-09-01, Cement Washdown}

A detailed site walkover along $20-\mathrm{ft}$ transects will be conducted either before or during the CAS investigations to identify any biasing factors as described in Section 4.2. Identified biasing factors will be assessed and sampled as necessary.

Figure B.8-5 shows a photograph of a portion of the 9.2-acre washdown area in its current condition. The planned Decision I sample locations are shown in Figure B.8-6.

\section{B.8.4 Corrective Action Site 06-44-05, Diesel Spill from Tank \#38061}

Three sample locations at CAS 06-44-05 will be located in the graded area west of the concrete building foundation of the former Upper Monastery Building. During the Decision I sampling effort, 


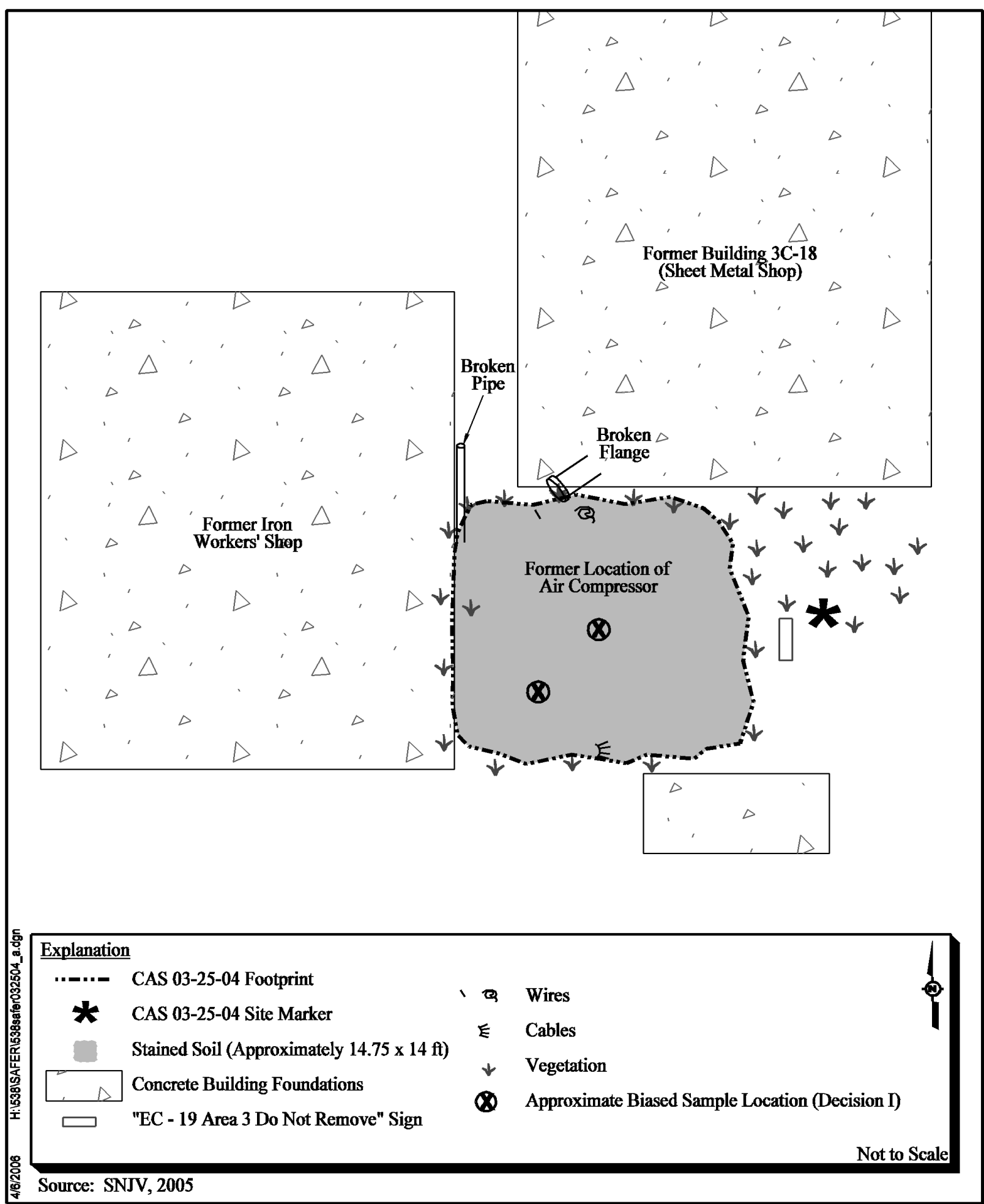

Figure B.8-4

CAS 03-25-04, Hydrocarbon Stain, Planned Sample Locations 


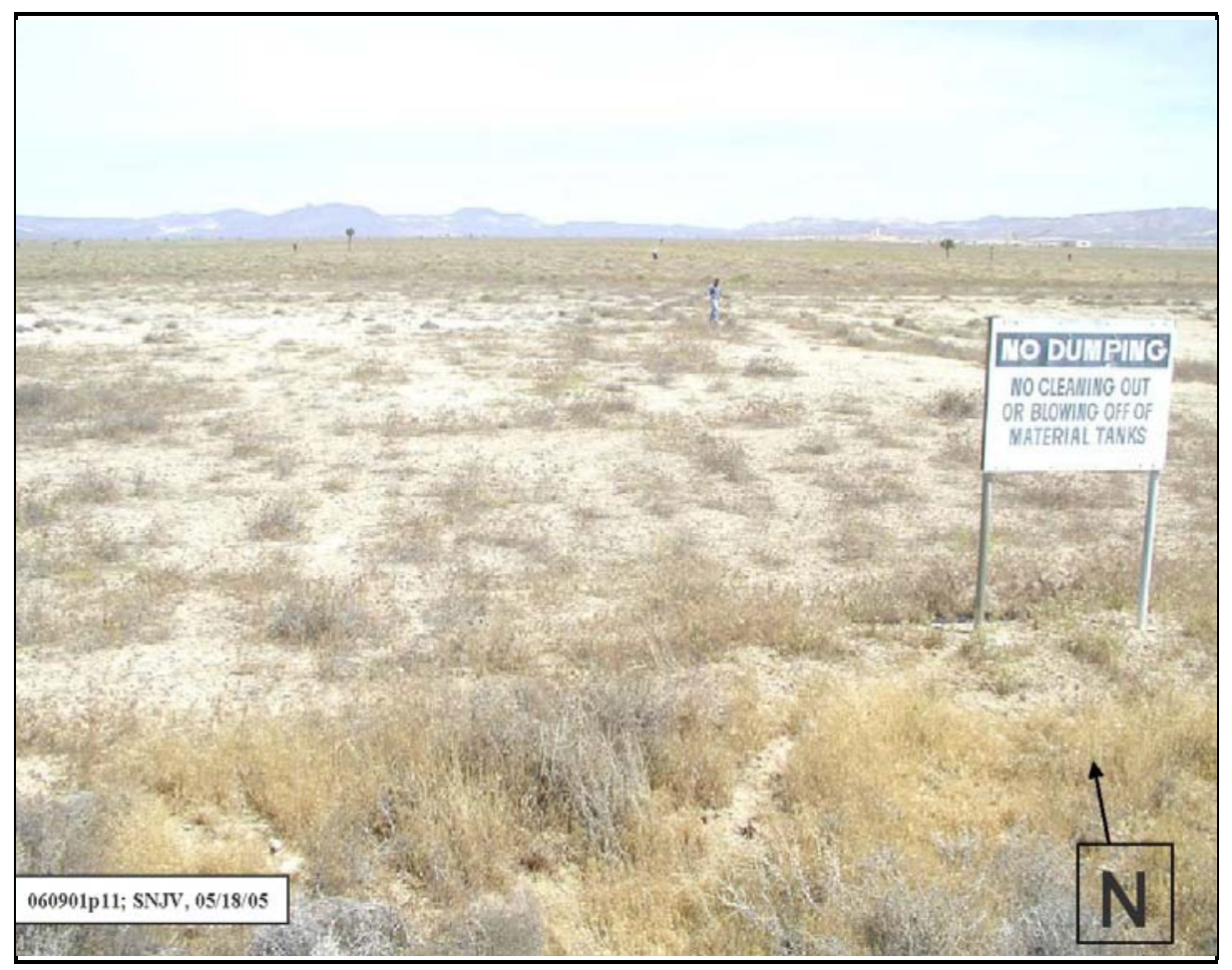

Figure B.8-5

Site Conditions at CAS 06-09-01

This photograph shows a section of the 9.2-acre cement washdown at CAS 06-09-01. A sign stating, "No Dumping No Cleaning Out or Blowing Off of Material Tanks" is visible in the foreground. (SNJV, 2005)

the graded surface will be excavated parallel to the CAS boundary and down to the native soil interface to observe any biasing factors such as staining that may have resulted from spills of petroleum hydrocarbon from the AST that was formerly located in the area. Samples will be collected from the most heavily stained section within each of the three sample locations. A subsequent interval below each sample will be collected and field screened. If FSRs exceed the FSLs and/or if biasing factors are present, the sample will be submitted for analysis. Select samples will be submitted for analysis in accordance with the analytical program listed in Table 3-1.

Figure B.8-7 shows the site conditions at the CAS. The planned Decision I sample locations are shown in Figure B.8-8. Additional Decision I and Decision II sample locations will be selected based on biasing factors described in Section B.4.2.1. 


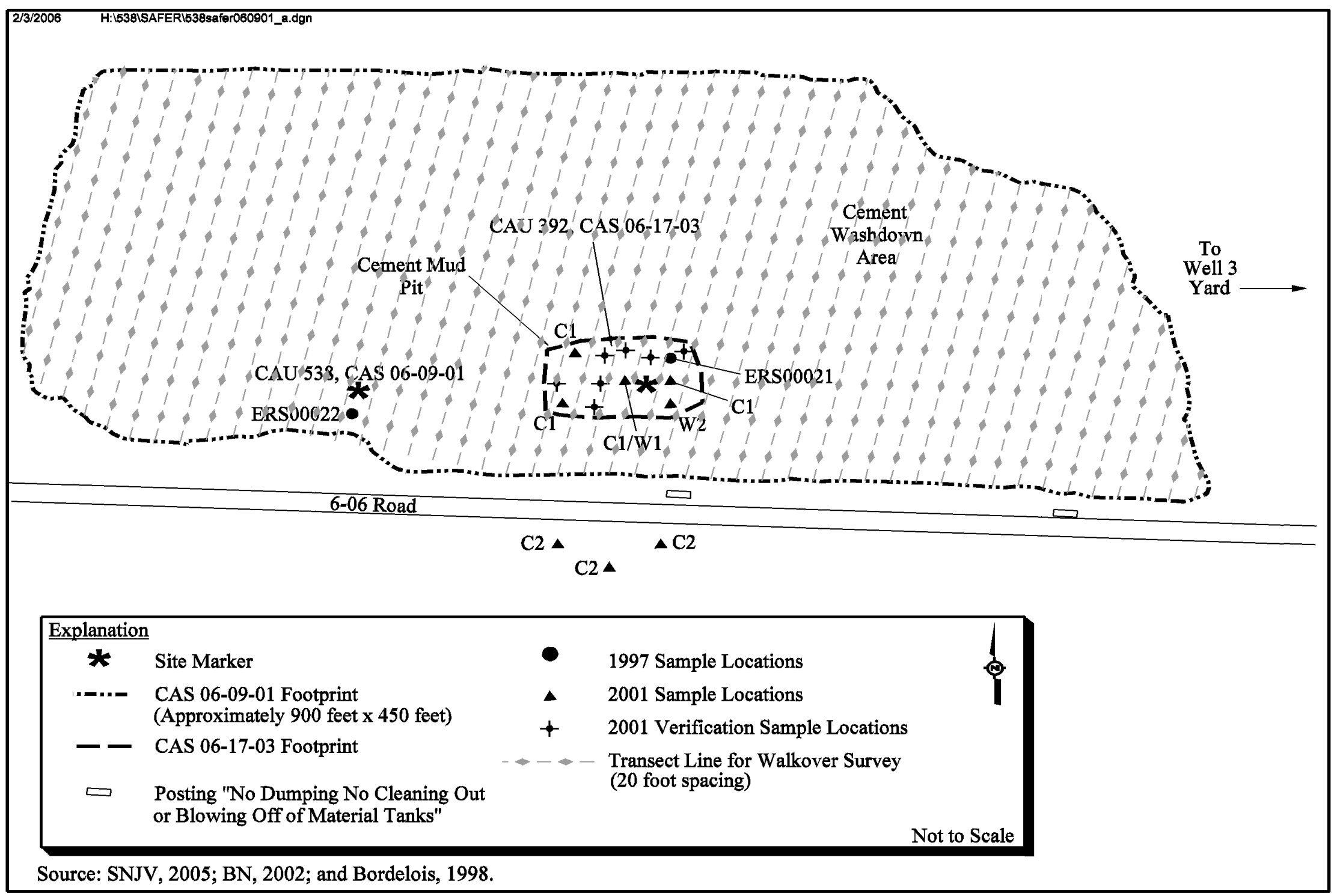

Figure B.8-6

CAS 06-09-01, Cement Washdown, Site Walkover 


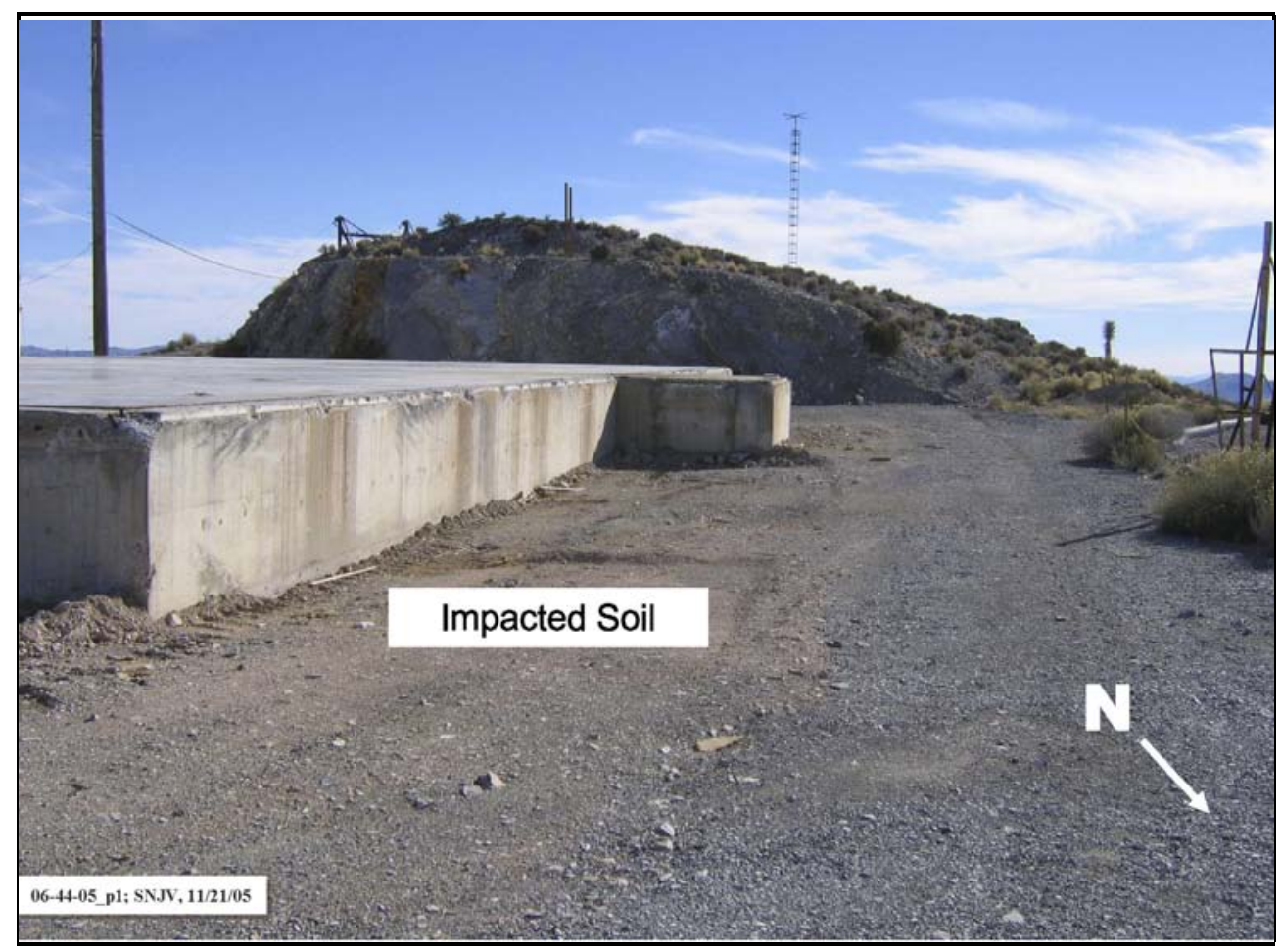

Figure B.8-7

Site Conditions at CAS 06-44-05

This photograph shows a view of the CAS 06-44-05 adjacent to the concrete foundation of the recently demolished Upper Monastery Building. (SNJV, 2005)

\section{B.8.5 Corrective Action Site 06-44-06, Spill Site with Hydrocarbons}

A minimum of 15 samples will be collected from 15 locations at CAS 06-44-06. A minimum of two samples will be collected of subsurface soil from within the use-restricted area associated with the former UST 6-CP-9. A minimum of 13 samples will be collected from surface and shallow subsurface soil in an area expanding approximately $60 \mathrm{ft}$ north of the former UST 6-CP-9. Samples will be submitted for analysis in accordance with the analytical program listed in Table B.2-3. A subsequent interval below each sample will be collected and field screened. If FSRs exceed the FSLs and/or if biasing factors are present, the sample will be submitted for analysis.

Figure B.8-9 shows the site conditions at the CAS. The planned Decision I sample locations are shown in Figure B.8-10. Additional Decision I and Decision II sample locations will be selected based on biasing factors described in Section B.4.2.1. 


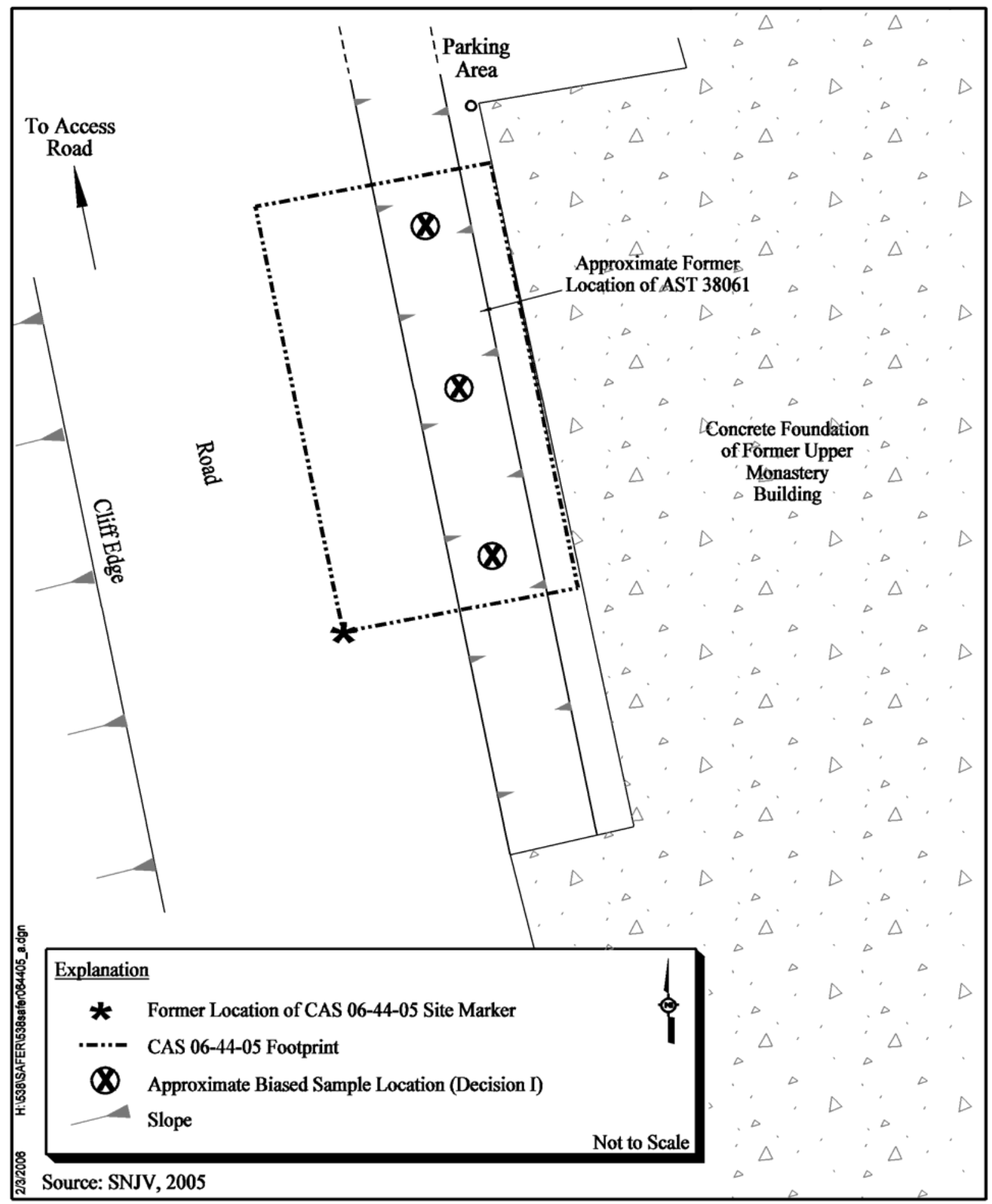

Figure B.8-8

CAS 06-44-05, Diesel Spill From Tank \#38061, Planned Sample Locations 


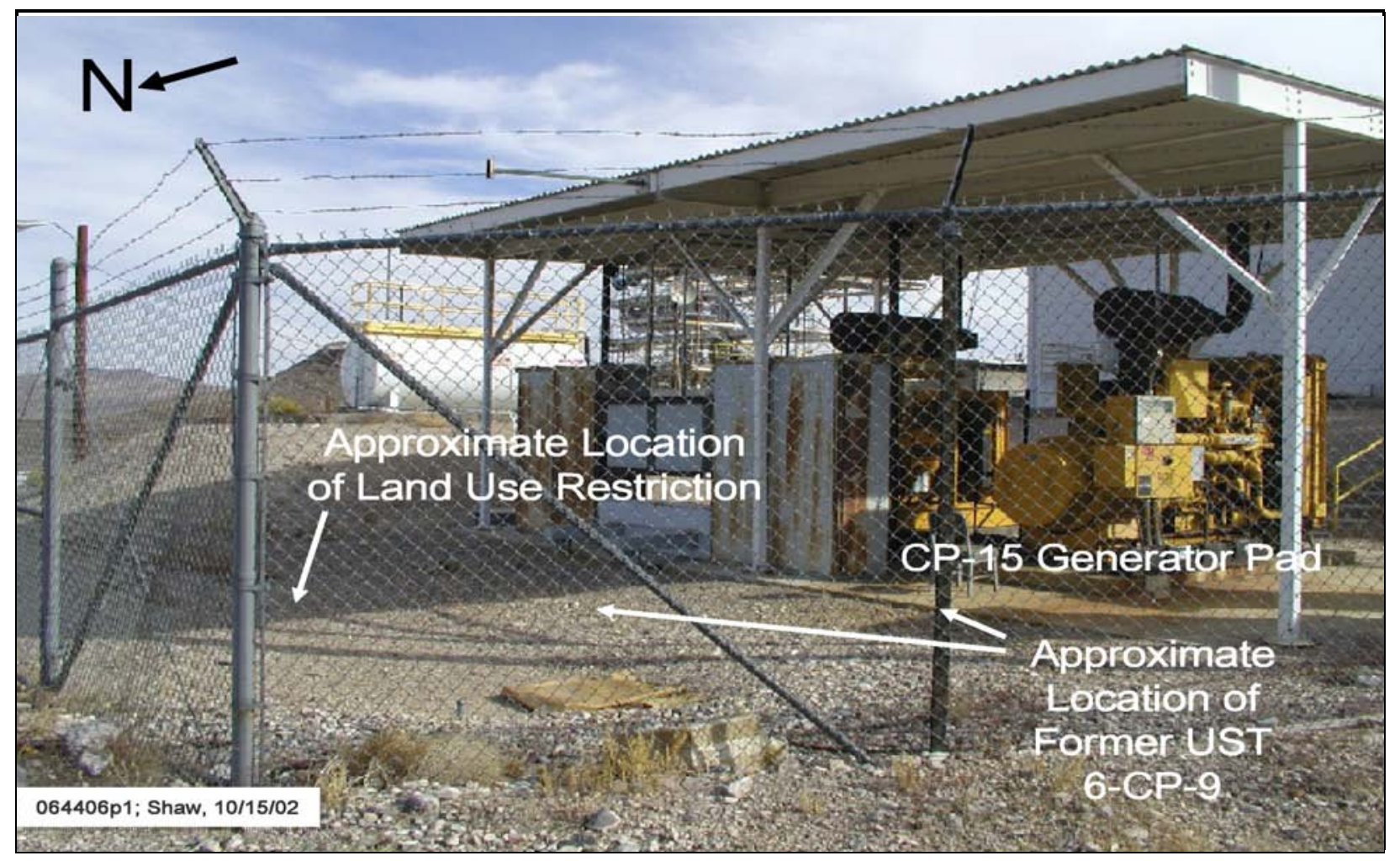

Figure B.8-9

Site Conditions at CAS 06-44-06

This photograph shows the former location of the excavated UST 6-CP-9 adjacent to the CP-15 generator pad. The use restriction located at the northeast corner of the excavated underground storage tank is the environmental concern at this CAS and is marked in the background. (Shaw, 2002)

\section{B.8.6 Corrective Action Site 12-29-06, Spill Site}

A minimum of 11 samples will be collected from 11 locations at CAS 12-29-06. One sample will be collected from the observed stain surface soil located northwest of the asphalt-covered building foundation. Six samples will be collected from soil surrounding the building foundation. One swipe sample will be collected from the thin oil substance on the old oil transformer located south of the substation to verify that PCBs are not a source of potential contamination. One sample will be collected from the degraded flooring to verify that there are no COCs in the degraded flooring that could become a source of environmental contamination. One sample will be collected from the visible soil stain near the northwest corner of the pad. In addition, one sample of asphalt will be collected from each of the two undisturbed locations outside of the CAS boundary to establish background levels for the hazardous constituents of asphalt. A subsequent interval below each soil sample will be collected and field screened. If FSRs exceed the FSLs and/or if biasing factors are 


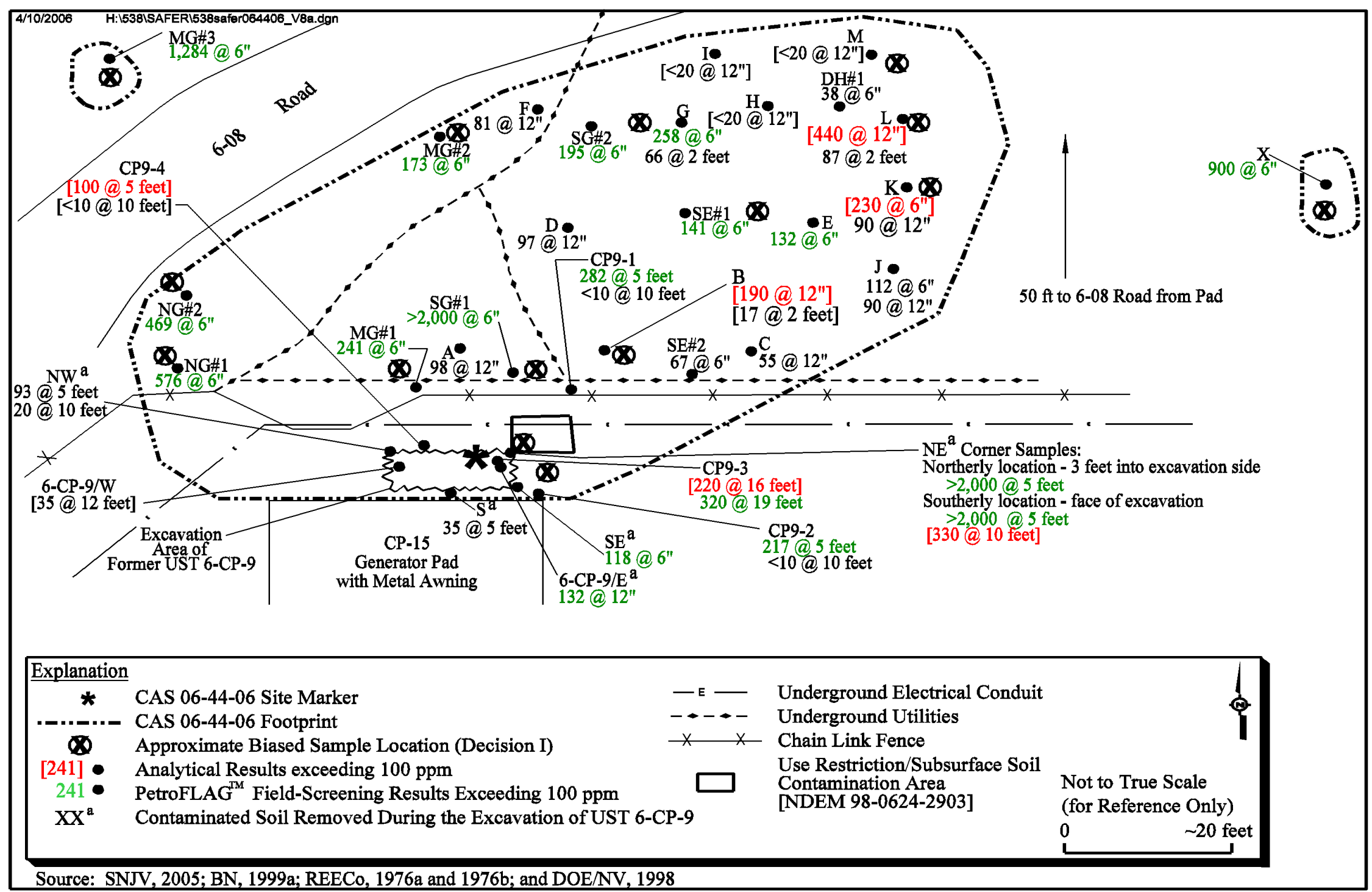

Figure B.8-10

CAS 06-44-06, Spill Site with Hydrocarbons, Planned Sample Locations 
present, the sample will be submitted for analysis. All samples will be submitted for analysis in accordance with the analytical methods listed in Table B.2-3.

Figure B.8-11 shows the site conditions of the CAS. The planned Decision I sample locations are shown in Figure B.8-12. Additional Decision I and Decision II sample locations will be selected based on biasing factors described in Section B.4.2.1.

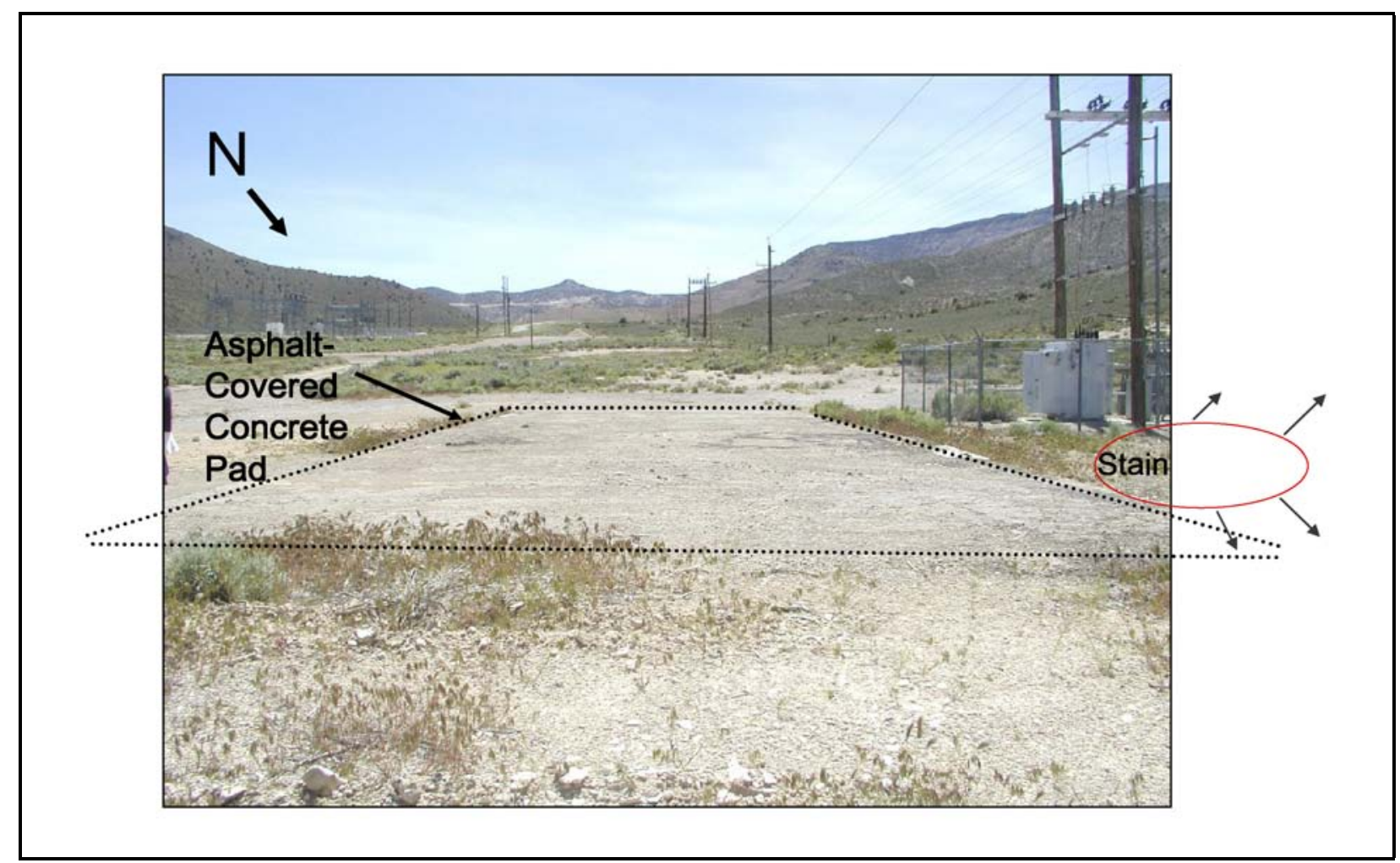

\section{Figure B.8-11 \\ Site Conditions at CAS 12-29-06}

This photograph shows an overall view of the asphalt-covered concrete pad at CAS 12-29-06. The environmental concern is the approximately 19-by-9-ft stain soil marked in the foreground. (SNJV, 2005)

\section{B.8.7 Corrective Action Site 23-25-01, Oil Stains}

A minimum of 11 samples will be collected from 11 biased sample locations identified at CAS 23-25-01. Six surface and shallow subsurface samples will be collected from six sample locations surrounding the former Building 146 concrete foundation. One sample will be collected at the surface and one at the shallow subsurface from the stained soil north of the building foundation 


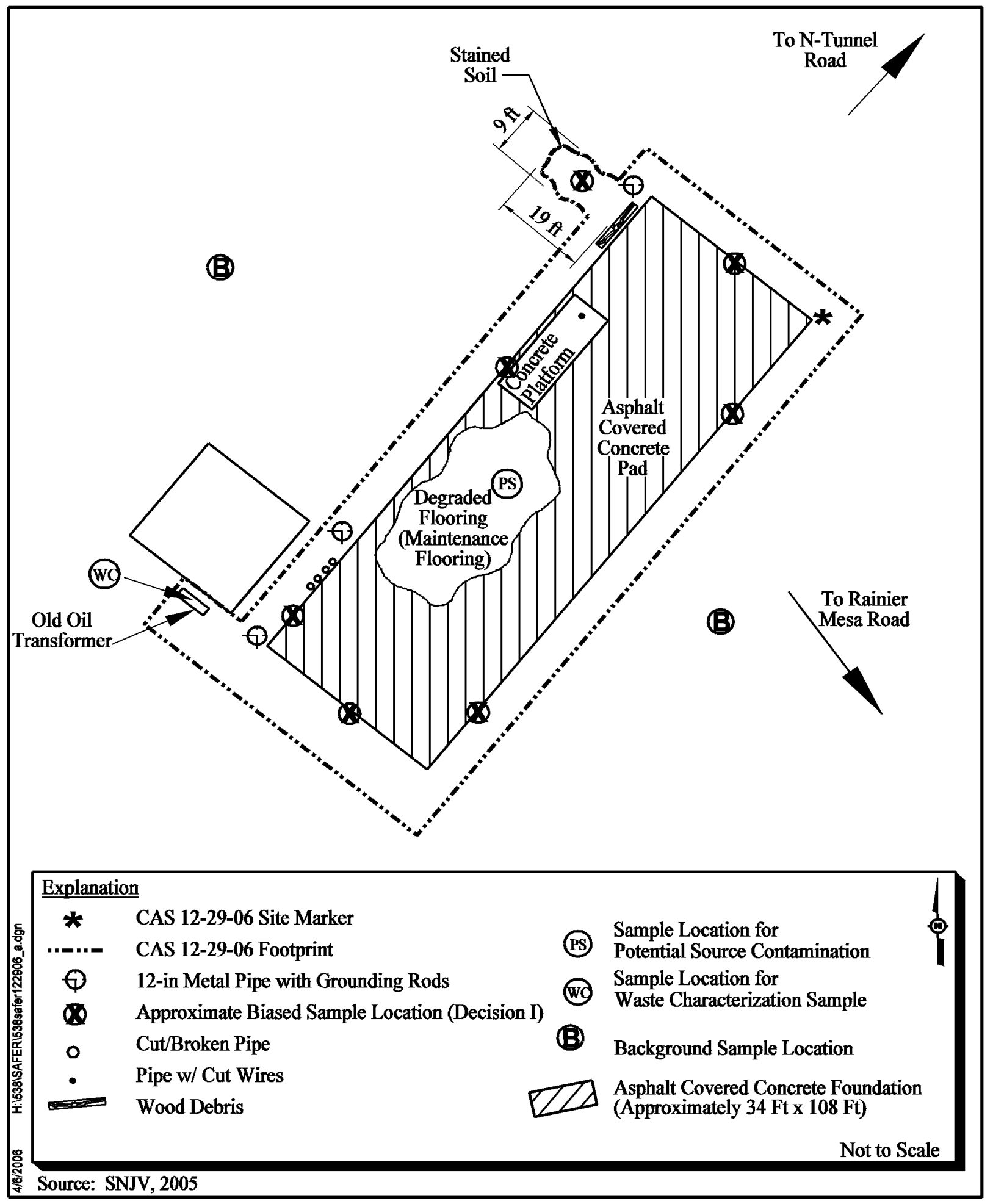

Figure B.8-12

CAS 12-29-06, Spill Site, Planned Sample Locations 
and at the sample location located at each of the two AST saddles. One asphalt sample will be collected from two undisturbed sample locations outside the CAS boundary.

Figure B.8-13 shows the site conditions of the CAS. The planned Decision I sample locations are shown in Figure B.8-14. Additional sample locations and Decision II sample locations will be selected based on biasing factors described in Section B.4.2.1.

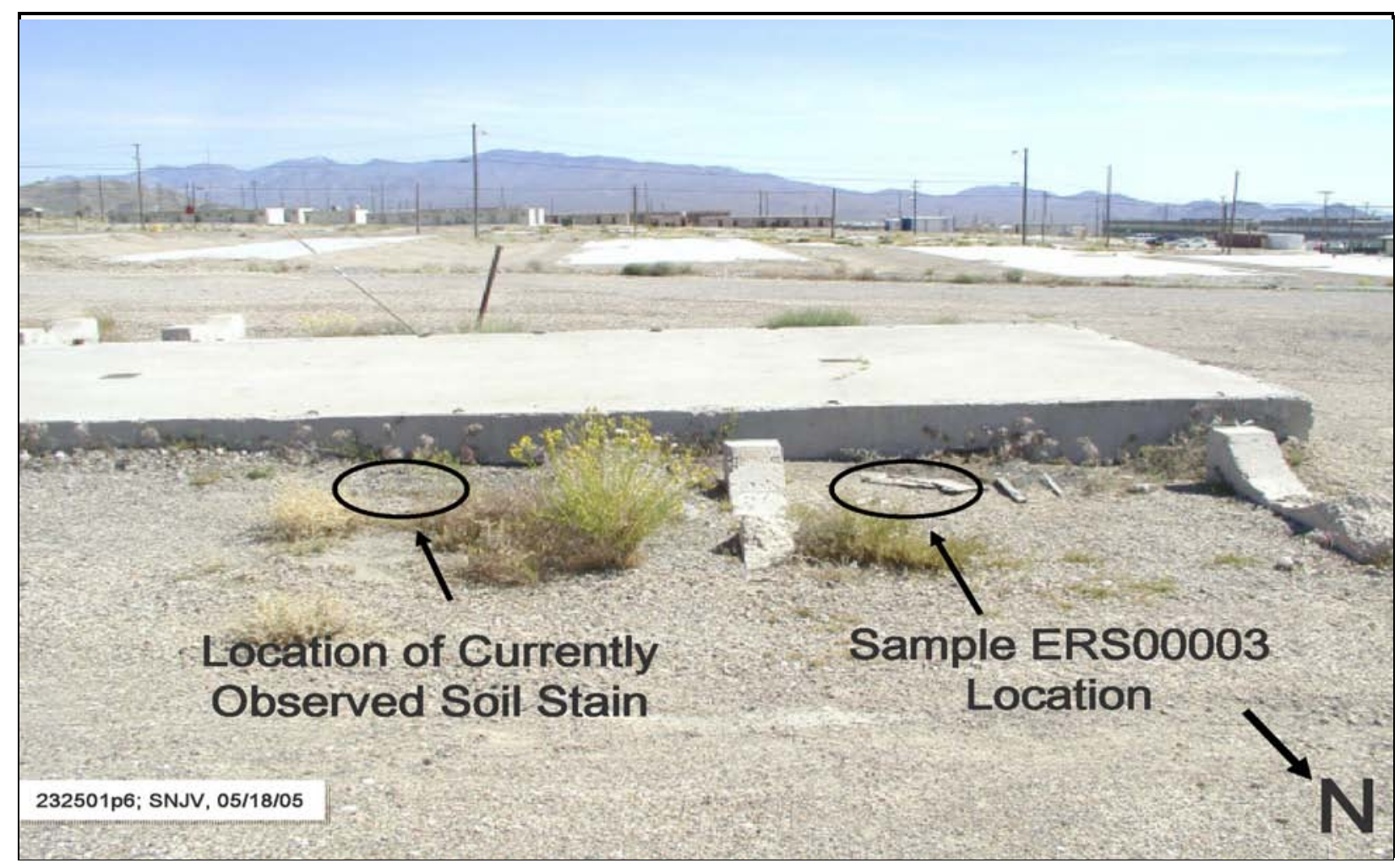

Figure B.8-13

\section{Site Conditions at CAS 23-25-01}

This photograph shows a current view of CAS 23-25-01. The location of soil sample ERS00003 collected at this site in 1997 is located in the foreground. The environmental concern at this CAS is the marked soil stain seen in the foreground. (SNJV, 2005) 


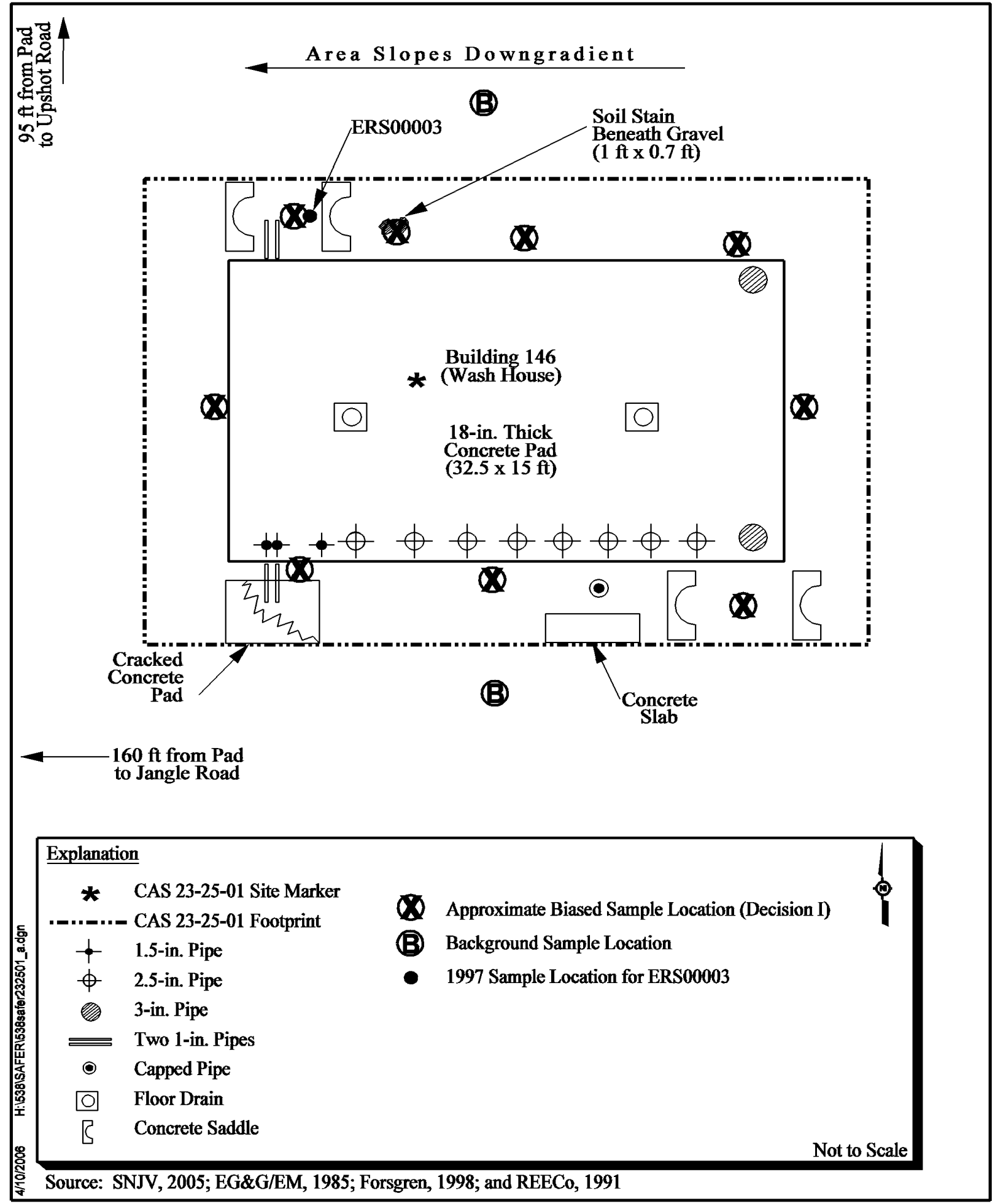

Figure B.8-14

CAS 23-25-01, Oil Stains, Planned Sample Locations 


\section{B.9.0 References}

ARL/SORD, see Air Resources Laboratory/Special Operations and Research Division.

ASTM, see American Society for Testing and Materials.

Air Resources Laboratory, Special Operations and Research Division. 2005. Air Resources Laboratory/Special Operations and Research Division Website. Accessed at http://www.sord.nv.doe.gov/raingage/htm on 25 May.

American Aerial Surveys, Inc. 1968. Aerial photograph U2y_Post-Test_8 of CAU 538, CAS 02-21-01, 18 January.

American Society for Testing and Materials. 1995. Standard Guide for Risk-Based Corrective Action Applied at Petroleum Release Sites/American Society for Testing and Materials,

ASTM E 1739-95 (Reapproved 2002). Philadelphia, PA.

BN, see Bechtel Nevada.

Bechtel Nevada. 1999a. Engineering drawing number JS-090-088-C12, entitled, "Nevada Test Site_Areas 6 \& 23 Installation of Five Aboveground Tanks 6-CP-9 \& Piping Plan," 23 March. Las Vegas, NV.

Bechtel Nevada. 1999b. Lithology and Stratigraphy of Holes Drilled in LANL-Use Areas of the Nevada Test Site, Volume XIII, 1991 - 1998, July. Prepared for U.S. Department of Energy. Las Vegas, NV.

Bechtel Nevada. 2002. Closure Report for Corrective Action Unit 392: Spill Sites and Construction Material, Nevada Test Site, Nevada. January. Prepared for U.S. Department of Energy, Nevada Operations Office. DOE/NV -- 778-REV 1. Las Vegas, NV.

Bordelois, B., IT Corporation. 1998. Letter to R. Jackson (ITLV) entitled, “CAU 245 CAS 06-09-01 Sampling Report," 8 August. Las Vegas, NV.

Cowser, D.K., Bechtel Nevada. 1998. Letter to K.A. Hoar (DOE/NV) entitled, "Underground Storage Tank 6-CP-9 (CADAC Building), Nevada Test Site Permanent Closure of Tank System and Site Characterization Plan Submittal." 11 August. Las Vegas, NV.

DOE/NV, see U.S. Department of Energy, Nevada Operations Office.

DRI, see Desert Research Institute. 
Desert Research Institute. 1996. ER-12-1 Completion Report, December. Prepared for U.S. Department of Energy, Nevada Operations Office. Las Vegas, NV.

Dynamic Graphics, Inc. 2002. EarthVision 7: Software for 3-D Modeling and Visualization, Version 7.5.2. Accessed on 27 November 2005. Alameda, CA.

EG\&G, see EG\&G Energy Measurements Inc.

EPA, see U.S. Environmental Protection Agency.

ERDA, see Energy Research and Development Administration.

EG\&G, Energy Measurements Inc. 1985. Aerial photograph 5116-82 of Mercury. Nellis Air Force Base, NV: Remote Sensing Laboratory Photo Library.

Energy Research and Development Administration. 1977. Final Environmental Impact Statement, Nevada Test Site, Nye County, Nevada, ERDA-155. Las Vegas, NV.

Forsgren, F. 1998. Memorandum to R. Jackson entitled, "CAU 397, CAS 23-25-01 Sampling Report," 23 March. Las Vegas, NV.

Holmes and Narver, Inc. 1969. Engineering drawing number unknown entitled, "Station U2 AV Post Test Topography," 31 October.

Holmes and Narver, Inc. 1981. Nevada Test Site Development Plan, Area 6 Submittal, 23 November. CIC 65753. Prepared for U.S. Dsepartment of Energy.

Howard, N., IT Corporation. 1977. Letter of Memorandum to distribution entitled, "U2ao Preliminary Site Characteristics Summary,” 22 March. Las Vegas, NV.

IT, see IT Corporation.

IT Corporation. 1997. Industrial Sites Preliminary Field Activity Daily Logs and field forms for CAU 538 site visit conducted on 19 February. Las Vegas, NV.

Kidman, R.L, Stoller-Navarro Joint Venture. 2005. Correspondence (email) to Linda Linden (Stoller-Navarro Joint Venture) regarding exposure scenarios, 30 November. Las Vegas, NV.

LLNL, see Lawrence Livermore National Laboratory.

Lawrence Livermore National Laboratory. 1982. Energy and Technology Review: The Geology of Yucca Flats, April, UCRL-52000-82-4. Livermore, CA.

NAC, see Nevada Administrative Code. 
NNSA/NSO, see U.S. Department of Energy, National Nuclear Security Administration Nevada Site Office.

NNSA/NV, see U.S. Department of Energy, National Nuclear Security Administration Nevada Operations Office.

Nevada Administrative Code. 1997. NAC 445A.22705, "Contamination of Soil: Evaluation of Site by Owner or Operator." Carson City, NV.

REECo, see Reynolds Electrical \& Engineering Co., Inc.

Ray, K.W. (Lawrence Radiation Laboratory). 1971. Letter of memorandum to distribution entitled, "Geology of Emplacement Hole U2br (Harebell Event)," 5 May.

Reynolds Electrical \& Engineering Co., Inc. 1976a. Engineering drawing number NV-35-84-02, drawing 2 of 64, entitled "Nevada Test Site - Area 6 Control and Data Acquisition Center (CADAC) Demolition Plan.” August. Las Vegas, NV.

Reynolds Electrical \& Engineering Co., Inc. 1976b. Engineering drawing number NV-35-84-02, drawing 4 of 64, entitled "Nevada Test Site - Area 6 Control and Data Acquisition Center (CADAC) Grading \& Paving Plan.” August. Las Vegas, NV.

Reynolds Electrical \& Engineering Co., Inc. 1991. Nevada Test Site Inventory of Inactive and Abandoned Facilities and Waste Sites Area 22-30, Volume 5 of 5. DOE/NV/10630-18. Las Vegas, NV.

Shaw, see Shaw Environmental and Infrastructure, Inc.

SNJV, see Stoller-Navarro Joint Venture.

SNL, see Sandia National Laboratories.

Sandia National Laboratories. 1982. Geology of the Nevada Test Site and Nearby Areas, Southern Nevada, October, SAND82-2207. Prepared by S. Sinnock. Albuquerque, NM.

Shaw Environmental and Infrastructure, Inc. 2002. Industrial Sites Preliminary Activity Daily Log and Field Forms for CAU 538 site visit conducted on 15 October. Las Vegas, NV.

Stoller-Navarro Joint Venture. 2005. Industrial Sites Preliminary Field Activity Daily Logs and Field Forms for CAU 538 site visits conducted on 18 May and 21 November. Las Vegas, NV.

Sygitowicz, L.S. Bechtel Nevada. 1998. Letter to K.A. Hoar (DOE/NV) entitled, "Transmittal of 30 Day Report for Nevada Division of Emergency Management (NDEM) Case Number 980624-2903 - Underground Storage Tank 6-CP-9,” 15 July. Las Vegas, NV. 
USGS, see U.S. Geological Survey.

USGS/DOE, see U.S. Geological Survey and U.S. Department of Energy.

U.S. Department of Energy, National Nuclear Security Administration Nevada Operations Office. 2002. Industrial Sites Quality Assurance Project Plan, Nevada Test Site, Nevada, Rev. 3, DOE/NV--372. Las Vegas, NV.

U.S. Department of Energy, National Nuclear Security Administration Nevada Site Office. 2005. NV/YMP Radiological Control Manual, Rev. 5, DOE/NV--11718-079, UC-702. Prepared by A.L. Gile of Bechtel Nevada. Las Vegas, NV.

U.S. Department of Energy, National Nuclear Security Administration Nevada Site Office. 2006. Industrial Sites Project Establishment of Final Action Levels, DOE/NV--1107. February. Las Vegas, NV.

U.S. Department of Energy, Nevada Operations Office. 1992. Remedial Investigation and Feasibility Study for the Plutonium Contaminated Soils at Nevada Test Site, Nellis Air Force Range and Tonopah Test Range, April. Las Vegas, NV.

U.S. Department of Energy, Nevada Operations Office. 1996. Final Environmental Impact Statement for the Nevada Test Site and Off-Site Locations in the State of Nevada, DOE/EIS 0243. Las Vegas, NV.

U.S. Department of Energy, Nevada Operations Office. 1998. "Closure Report for Underground Storage Tank Release Sites at the Nevada Test Site: UST6-619-3 (NDEM \# 98-0909-3054), UST 6-CP-40 (NDEM \#98-0413-2764) and UST 6-CP-9 (NDEM \#98-0624-2903)." Prepared by Bechtel Nevada Environmental Restoration. Las Vegas, NV.

U.S. Environmental Protection Agency. 2000a. Data Quality Objectives Process for Hazardous Waste Site Investigations. EPA QA/G-4HW. Washington, DC.

U.S. Environmental Protection Agency. 2000b. Guidance for the Data Quality Objective Process, EPA QA/G4. Washington, DC.

U.S. Environmental Protection Agency. 2002. Guidance for Quality Assurance Project Plans, EPA QA/G5. Washington, DC.

U.S. Geological Survey. 1961. Ground Water Test Well A, Nevada Test Site, Nye County, Nevada Summary of Lithologic Data, Aquifer Tests, and Construction, Report TEI-800. Prepared by C.E. Price and W. Thordarson. 
U.S. Geological Survey. 1995. Precipitation Data for Water Years 1992 and 1993 from a Network on Nonrecording Gauges at Yucca Mountain, Nevada. USGS-OFR-95-146. Prepared by D.S. Ambos and A.L. Flint, and J.A. Hevesi for the U.S. Department of Energy, Nevada Operations Office. Las Vegas, NV.

U.S. Geological Survey. 1996. Summary of Hydrogeologic Controls on Ground-Water Flow at the Nevada Test Site, Nye County, Nevada, WRIR 96-4109. Prepared by R.J. Laczniak, J.C. Cole, D.A. Sawyer, and D.A. Trudeau. Denver, CO.

U.S. Geological Survey and U.S. Department of Energy. 2005. "USGS/DOE Nevada Well WW-A WWW Site Page," as accessed at http://nevada.usgs.gov/doe_nv/area3/ww-a.asp on 5 July 2005.

Winograd, I.J., and W. Thordarson. 1975. Hydrology and Hydrochemical Framework, South-Central Great Basin, Nevada-California, with Special Reference to the Nevada Test Site, USGS Professional Paper 712-C. Denver, CO.

Wuellner, J.W., Reynolds Electrical \& Engineering Co., Inc. 1994. Memorandum to J.P. Bielawski (REECo) entitled, "Historical Information Area 3 Waste Mud Impoundment," 2 May. Las Vegas, NV. 


\section{Appendix C}

\section{Area 6 Land Use Restrictions and Bechtel Nevada Use Restriction Information for UST 6-CP-9}




\section{C.1.0 Control Point South Land Use Restrictions}

Land Use Restrictions are restrictions that have been placed on the use of real estate within the NTS. These restrictions are established to identify health and safety considerations that are needed to work in areas where a release of contamination may have occurred, maintain containment controls at certain release sites, or identify other restrictions that have been established. Table C.1-1 provides the NDEM or CAU/CAS number, name, description, coordinates, and notice of completions.

Figure C.1-1 shows the approximate location of each Land Use Restriction located in Area 6. The restrictions that have been established for each piece of real estate may differ from site to site and are identified in the use restriction itself.

Table C.1-1

Area 6 Land Use Restriction Site Location Nevada Division of Emergency Management (Page 1 of 3)

\begin{tabular}{|c|c|c|c|c|}
\hline NDEM Number & Site Description & \multicolumn{2}{|c|}{$\begin{array}{l}\text { GPS Location from the NW } \\
\text { Corner of the LUR Going } \\
\text { Clockwise to the SW Corner }\end{array}$} & $\begin{array}{l}\text { CAU Notice } \\
\text { of } \\
\text { Completion }\end{array}$ \\
\hline \multicolumn{5}{|c|}{1 Underground Storage Tank, Building 06-619 } \\
\hline \multirow{5}{*}{$\begin{array}{c}\text { NDEM } \\
98-0909-3054\end{array}$} & \multirow{5}{*}{$\begin{array}{c}\text { Underground Storage } \\
\text { Tank (UST) 6-619-3 at } \\
\text { Building 06-619 Gas } \\
\text { Station }\end{array}$} & \multicolumn{2}{|c|}{ UTM Zone 11, NAD 27, Meters. } & \multirow{5}{*}{$\mathrm{N} / \mathrm{A}$} \\
\hline & & N 4089827.75 & E 584634.02 & \\
\hline & & N 4089872.72 & E 584637.98 & \\
\hline & & N 4089870.32 & E 584638.00 & \\
\hline & & N 4089870.25 & E 584634.01 & \\
\hline \multicolumn{5}{|c|}{2 Underground Heating Oil Tank, Building 06-CP-70 } \\
\hline \multirow{5}{*}{$\begin{array}{c}\text { NDEM } \\
98-1202-3196\end{array}$} & \multirow{5}{*}{$\begin{array}{l}\text { Underground Heating } \\
\text { Oil Tank 6-CP-1 at } \\
06-\text {-CP-70 Fire Station }\end{array}$} & \multicolumn{2}{|c|}{ UTM Zone 11, NAD 27, Meters. } & \multirow{5}{*}{$\mathrm{N} / \mathrm{A}$} \\
\hline & & N 4087791.24 & E 584493.27 & \\
\hline & & N 4087791.32 & E 584509.03 & \\
\hline & & N 4087775.74 & E 584516.08 & \\
\hline & & N 4087772.40 & E 584503.46 & \\
\hline
\end{tabular}


Table C.1-1

Area 6 Land Use Restriction Site Location Nevada Division of Emergency Management (Page 2 of 3)

\begin{tabular}{|c|c|c|c|c|}
\hline NDEM Number & Site Description & \multicolumn{2}{|c|}{$\begin{array}{l}\text { GPS Location from the NW } \\
\text { Corner of the LUR Going } \\
\text { Clockwise to the SW Corner }\end{array}$} & $\begin{array}{l}\text { CAU Notice } \\
\text { of } \\
\text { Completion }\end{array}$ \\
\hline \multicolumn{5}{|c|}{3 Underground Storage Tank, Building 06-CP-1 } \\
\hline \multirow{5}{*}{$\begin{array}{l}\text { No number issued } \\
\text { UST closed in } \\
\text { place }\end{array}$} & \multirow{5}{*}{$\begin{array}{c}\text { Underground Storage } \\
\text { Tank (UST) 6-CP-1B } \\
\text { at 06-CP-1 Control } \\
\text { Point } 1\end{array}$} & \multicolumn{2}{|c|}{ UTM Zone 11, NAD 27, Meters. } & \multirow{5}{*}{ N/A } \\
\hline & & N 4087937.68 & E 584250.94 & \\
\hline & & N 4087937.64 & E 584254.40 & \\
\hline & & N 4087930.53 & E 584254.15 & \\
\hline & & N 4087930.57 & E 584250.83 & \\
\hline \multicolumn{5}{|c|}{4 Underground Storage Tank, Building 06-CP-9 } \\
\hline \multirow{5}{*}{$\begin{array}{c}\text { NDEM } \\
98-0624-2903\end{array}$} & \multirow{5}{*}{$\begin{array}{c}\text { Underground Storage } \\
\text { Tank (UST) 6-CP-9 at } \\
\text { 06-CP-9 CADAC }\end{array}$} & \multicolumn{2}{|c|}{ UTM Zone 11, NAD 27, Meters. } & \multirow{5}{*}{ N/A } \\
\hline & & N 4087905.83 & E 584221.68 & \\
\hline & & N 4087905.88 & E 584223.92 & \\
\hline & & N 4087904.27 & E 584223.95 & \\
\hline & & N 4087904.31 & E 584221.71 & \\
\hline \multicolumn{5}{|c|}{5 Underground Storage Tank, Building 06-CP-40 } \\
\hline \multirow{5}{*}{$\begin{array}{c}\text { NDEM } \\
98-0413-2764\end{array}$} & \multirow{5}{*}{$\begin{array}{c}\text { Underground Storage } \\
\text { Tank (UST) 6-CP-40 at } \\
\text { 06-CP-40 } \\
\text { Communications and } \\
\text { Electronics }\end{array}$} & UTM Zone 11 & D 27, Meters. & \multirow{5}{*}{ N/A } \\
\hline & & N 4087848.11 & E 584105.57 & \\
\hline & & N 4087847.77 & E 584111.25 & \\
\hline & & N 4087835.19 & E 584106.05 & \\
\hline & & N 4087838.77 & E 584101.68 & \\
\hline
\end{tabular}


Table C.1-1

Area 6 Land Use Restriction Site Location Nevada Division of Emergency Management (Page 3 of 3)

\begin{tabular}{|c|c|c|c|c|}
\hline NDEM Number & Site Description & \multicolumn{2}{|c|}{$\begin{array}{l}\text { GPS Location from the NW } \\
\text { Corner of the LUR Going } \\
\text { Clockwise to the SW Corner }\end{array}$} & $\begin{array}{l}\text { CAU Notice } \\
\text { of } \\
\text { Completion }\end{array}$ \\
\hline \multicolumn{5}{|c|}{6 CAU 326 Area 6 and 27 Release Sites, Nevada Test Site, Nevada } \\
\hline \multirow{20}{*}{$06-25-01$} & \multirow{20}{*}{$\begin{array}{l}\text { CP-1 Heating Oil } \\
\text { Release/Heating Oil } \\
\text { Release associated } \\
\text { with broken feed and } \\
\text { return pipelines } \\
\text { running from Tank } \\
6-\mathrm{CP}-1 \text { to Area } 6 \mathrm{CP}\end{array}$} & \multicolumn{2}{|c|}{ UTM Zone 11, NAD 27, Meters. } & \multirow{20}{*}{$01 / 03 / 03$} \\
\hline & & \multicolumn{2}{|c|}{ Area inside CP fenced compound } & \\
\hline & & N 4087847.009 & E 584310.243 & \\
\hline & & N 4087847.188 & E 584324.116 & \\
\hline & & N 4087838.228 & E 584334.606 & \\
\hline & & N 4087837.982 & E 584368.923 & \\
\hline & & N 4087827.594 & E 584369.000 & \\
\hline & & N 4087827.955 & E 584334.497 & \\
\hline & & N 4087837.182 & E 584324.988 & \\
\hline & & N 4087836.648 & E 584309.977 & \\
\hline & & \multicolumn{2}{|c|}{$\begin{array}{l}\text { Area in parking lot west of Building } \\
\mathrm{CP}-70 \text {, site of original pipeline break }\end{array}$} & \\
\hline & & N 4087836.511 & E 584399.978 & \\
\hline & & N 4087835.570 & E 584444.461 & \\
\hline & & N 4087825.222 & E 584445.108 & \\
\hline & & N 4087826.235 & E 584400.331 & \\
\hline & & \multicolumn{2}{|c|}{$\begin{array}{l}\text { Area covering break in southern } \\
\text { pipeline south of the parking lot north } \\
\text { of the CP access road }\end{array}$} & \\
\hline & & N 4087791.385 & E 584414.991 & \\
\hline & & N 4087790.554 & E 584420.998 & \\
\hline & & N 4087781.988 & E 584419.358 & \\
\hline & & N 4087783.001 & E 584413.405 & \\
\hline \multicolumn{2}{|c|}{$\begin{array}{l}\text { CP = Control Point } \\
\text { GPS = Global positioning system } \\
\text { LUR = Land Use Restriction } \\
\text { N/A = Not applicable } \\
\text { NAD = North American Datum }\end{array}$} & \multicolumn{3}{|c|}{$\begin{array}{l}\text { NDEM = Nevada Division of Emergency } \\
\text { NW }=\text { Northwest } \\
\text { SW = Southwest } \\
\text { UTM = Universal Transverse Mercator }\end{array}$} \\
\hline
\end{tabular}




\section{Bechtel Nevada}

\section{USE RESTRICTION INFORMATION}

Site Description: Site of former underground storage tank (UST) 6-CP-2 at NTS Area 6 CP

Applicable Facility Numbers/Descriptions: Eormer UST 6-CP-9 was located approximately

1 meter ( 3 feet) north of the Area $6 \mathrm{CP}$ generator pad

Petroleum bydrocarbon release was at northeast cormer of UST 6-CP.9.

NDEM Spill Number 98-0624-2903.

Contact (organization/project): Environment. Safety \& Heaith Division, DOEAVV

Surveyed Area (UTM coordinates; minimum bounding rectangle):

NW comer: $4,087,905,83 \mathrm{mN}, 584,221.68 \mathrm{mE}$; NE comer: $4,087,905.88 \mathrm{mN}, 584,223,22 \mathrm{mE}$; SW comer: $4,087,904.31 \mathrm{mN}, 584,221.71 \mathrm{mE} ; \mathrm{SE}$ comer: $4,087,904.22 \mathrm{mN}, 584,223.95 \mathrm{mE}$.

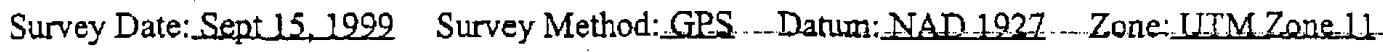

Site Monitoring Requirements: NONE

Required Frequency (quarterly, annually?): NA

If Monitoring has started, indicate Last Completion Date:NA.

\section{USE RESTRICTION}

Regulated substances have been identified to be present below ground surface at the above-surveyed location. Any subsurface activities which may disturb these substances and/or containment controls in any way must adequately address sitespecific Health and Safety precautions, environmental regulations, appropriate waste (including soil) handling and disposal, and other appropriate issues. This use restriction is documented by DOE for the NTS and has been approved by the Nevada Division of Environmental Protection through closure documentation for this site.

See the Closure Report for additional information on the condition of the site(s) and any monitoring and/or inspection requirements.

Comments: Diesel is present in soilat a depth of approximately 3.0 to 4.6 meters $(10$ to 15 feet) below ground surface in the above-surveyed location. Refer to the closure report for more details: "Closure Report for Underground Storage Tank Releases at the Nevada Test Site: UST 6-619-3 ADEM $=98-0909-3054) ;$ UST 6-CP-40 (NDEM \#98-0410-2764); UST 6-CP-9 (NDEM \#98-0624-2903)"DOENV December.1998

Submitted By: Signed copy on file Date:

Atrachments; Capy of survey map

Distribution: Closute Repont recipients Projet file 


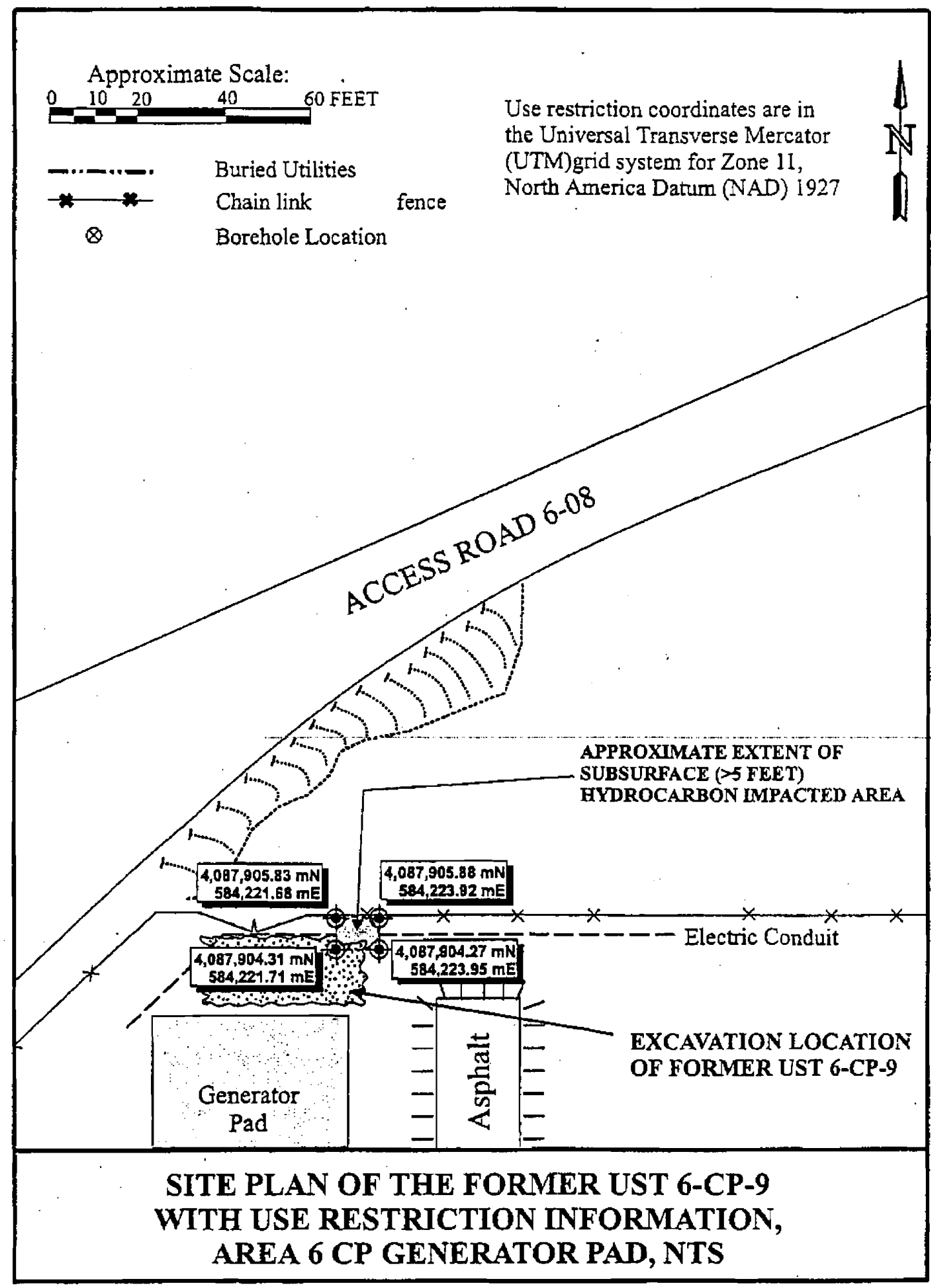

Figure C.1-1

Control Point South Facilities 


\section{Appendix D}

\section{Nevada Division of Environmental Protection Comments}

(2 Pages) 
February 28, 2006

Ms. Janet Appenzeller-Wing

Acting Director, Environmental Restoration Project

National Nuclear Security Administration

Nevada Site Office

P. O. Box 98518

Las Vegas, NV 89193-8518

RE: Review of Draft Streamlined Approach for Environmental Restoration (SAFER)

Plan for Corrective Action Unit 538, Spill Sites, Nevada Test Site, Nevada

Revision 0, February 2006

The Nevada Division of Environmental Protection, Bureau of Federal Facilities (NDEP) staff reviewed the draft SAFER Plan for Corrective Action Unit (CAU) 538, Spill Sites. NDEP has not found any issues or concerns.

If you have any questions, please contact Jeff MacDougall, Ph.D. at (702) 486-2850 ext 233 , or me at (702) $486-2850$ ext 229.

Sincerely,

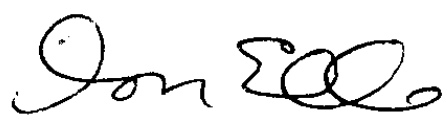

Don Elle, Ph.D.

Bureau of Federal Facilities

DRE/JJM/jjm

ACTION

INFO

NSO/MGR

AMEM

AMNS

AMSO

AMSP

AMSS

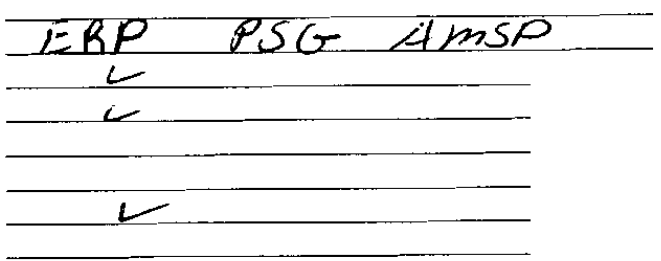


cc: P. L. Hall, TD, NNSANNSO, Las Vegas, NV

K. A. Hoar, AD/AMSP, NNSA/NSO, Las Vegas, NV

W. R. Griffin, SNJV/DTRA, M/S 645, Mercury, NV

D. C. Loewer, DTRA/TDTN, M/S 645, Mercury, NV

T. A. Lantow, DTRA/TDTNS, M/S 645, Mercury, NV

S. T. Curtis, ERD, NNSA/NSO, Las Vegas, NV

J. L. Smith, BN, Las Vegas, NV

R. F. Boehlecke, SNJV, Las Vegas, NV 


\title{
Library Distribution List
}

\author{
$\underline{\text { Copies }}$ \\ U.S. Department of Energy \\ 1 (Uncontrolled) \\ National Nuclear Security Administration \\ Nevada Site Office \\ Technical Library \\ P.O. Box 98518, M/S 505 \\ Las Vegas, NV 89193-8518 \\ U.S. Department of Energy \\ 1 (Uncontrolled, electronic copy) \\ Office of Scientific and Technical Information \\ 1 (Uncontrolled, electronic copy) \\ P.O. Box 62 \\ Oak Ridge, TN 37831-0062 \\ Southern Nevada Public Reading Facility \\ 2 (Uncontrolled, electronic copies) \\ c/o Nuclear Testing Archive \\ P.O. Box 98521, M/S 400 \\ Las Vegas, NV 89193-8521 \\ Manager, Northern Nevada FFACO \\ 1 (Uncontrolled, electronic copy) \\ Public Reading Facility \\ c/o Nevada State Library \& Archives \\ Carson City, NV 89701-4285
}

